*avis View/Frint Document Cover Sheet

This document was retrieved from the Boeing ISEARCH System.

Accession \#: D196070165

Document \#: SD-610-PSAR-002

Title/Desc:

PRELIMINARY SAFETY ANALYSIS REPORT FOR PROJECT 89-GEB-610 PFP INSTRUMENTATION UPGRADE 


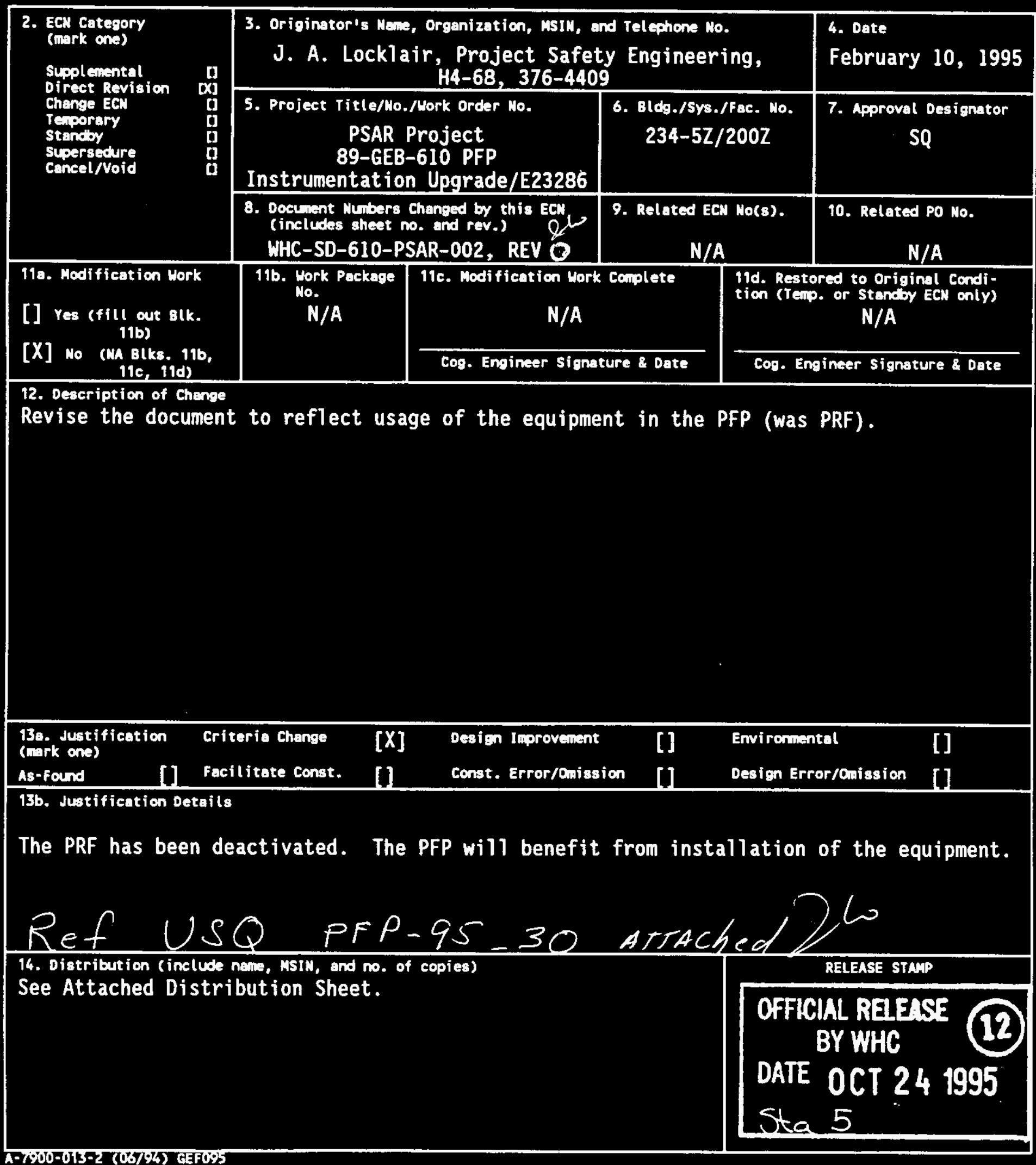




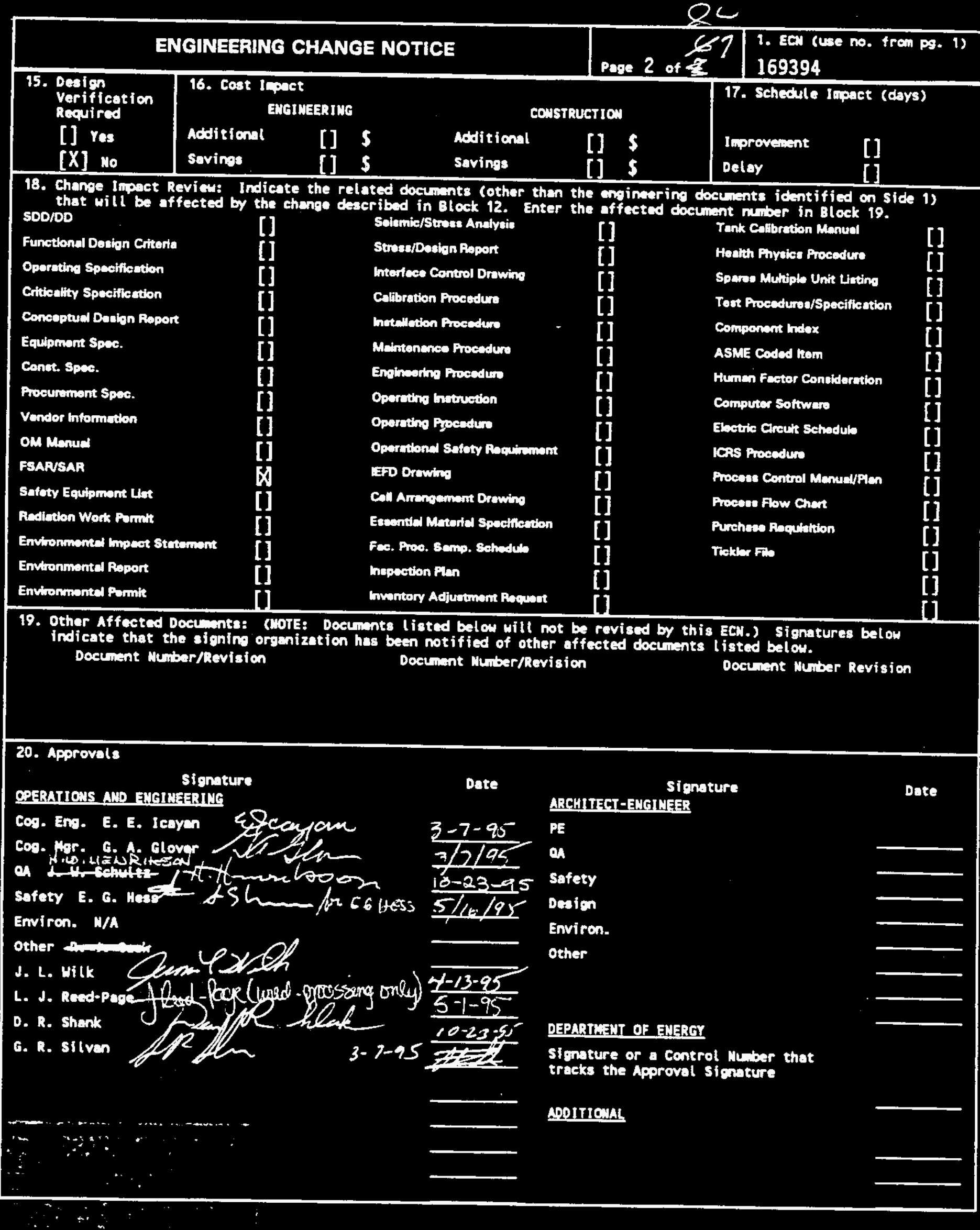


REFERENCE ITEM *: PFP-95-30, PROJECT B-610

\section{TITLE: PFP INSTRUMENT UPGRADE}

\section{Description of CHANGE or DISCOVERY:}

This project shall install a Micon Co. distributed process monitor and control system with Sparc Sun workstation operator interfaces. The Sparc workstations are housed in consoles custom designed to human factors specifications. The distributed control system (DCS) shall have the installed capacity to monitor and control all related instruments and equipment presently connected to the panels in the PFP Power control Room $321 \mathrm{~A}$ as 1 isted in the input/output 1 ist. This also includes all devices monitored and controlled by the 2736-ZB Allen Bradley progranmable logic controller. The system has since assumed the control and monitoring responsibilities for Projects B-680H "Low Level Waste Treatment Facility" and C-031H "PFP Liquid Effluent Facilities". Part of the new men's change area in Building 234-5ZA, Room 712, has been remodelled to house two operator consoles and one supervisor console. Local control units containing the microprocessor controllers and the input/output interface circuit boards shall be wired to the field instrumentation and controlled equipment. These units communicate with the Sparc workstations via a redundant data communications highway and shall be strategically placed throughout the PFP facility.

The DCS has already been purchased from Micon Co., located in Houston Texas, and is presently on site.

In addition to the DCS, this project shall provide the following:

- Signal conditioning instruments in the existing power control room 321A.

- Power, control and signal wiring cable and associated conduit.

- New raceways between the converted signal points or instruments and the Loca] Control Units (LCU).

- An engineering workstation now located in a trailer M0-016 to insure easy access to plant engineering personnel.

- Replace all control functions presentiy being performed by the Allen Bradley programmable logic controller (PLC) and thereby making obsolete the PLC.

- Removal and disposal of all replaced equipment (racks, panels, cables, etc.).

- Conversion of hard-wired interlock logic with DCS implemented logic (uniess hardwired interlocks are required for safety considerations such as safety class 1 or 2 interlocks).

This project shall replace those devices such as sensing elements, flow meters, or final control devices that cannot be made compatible to or be interfaced with the new control system.

QUESTIONS (Syporting information is required for esch question. Attach odditional peges as macessory. specifically note SAR sections and/or TSRs reviewed to cone to conclusion.)

MRP 5.12, Figure 5. (2/95) 
1. Does the PROPOSED CHANGE or DISCOVERY increase the probability of occurrence of an accident previously evaluated in the safety basis?

[x] No [] Yes/Maybe

Basis: While the DCS assumes the control and monitoring functions it does not impose upset conditions beyond those already addressed in the PFP SAR. The modifications made under this project will not introduce any new types of accidents and in all cases should enhance control and readout reliability. This would result in decreased risk due to a decrease in accident probability without any offsetting increase in consequences.

2. Does the PROPOSED CHANGE or DISCOVEAY increase the consequences of an accident previously evaluated in the safety basis?

\section{[x] No [] Yes/Maybe}

Basis: The PFP SAR identified the 234-5Z, the 236-Z, the 2736-Z, and the 2736-2B buildings as being susceptible to a ventilation upset consisting of either an excess pressurization or an excess depressurization of the building.

The PFP SAR concluded that in the 2736-ZB building, a release could be manifested if an incredible set of circumstances were to occur, but that the release would have insignificant impact on any onsite or offsite receptors.

As a result of these findings the PFP safety analys is report judged ventilation system components to warrant a Safety Class 3 or 4 rating.

The systems to be absorbed by the DCS are HVAC or other Safety Class 3 or 4 systems. Components of a higher Safety Class (i.e. 1 and 2) will be monitored by the DCS only on a secondary basis with the primary control and monitoring of these systems by their own separately qual ified components.

3. Does the PROPOSED CHANGE or DISCOVERY increase the probability of occurrence of a malfunction of equipment important to Safety previously evaluated in the safety basis?

\section{[x] No [] Yes/Maybe}

Basis: The Safety Class Equipment Document WHC-SD-CP-TI-108, 1 ists 15 annunciators that are classified as Safety Class 1 and they will be affected by the project during the conversion of the instrumentation and alarms in room 321A to the DCS. A special conduit and wires have already been installed by the project between the new control room ( $\mathrm{rm} 712$ ) and $321 \mathrm{~A}$ to assume these Safety Class 1 annunciators. In the new control room the plant will design and install a seismically qualified stand alone annunciator panel powered by its own UPS to display these alarms. The annunciator panel must withstand the consequences of a DBE and alarm on loss of a field signal or continuity of field wiring (i.e. connection failure shall show up as a alarm - fail safe). The DCS shall only provide secondary annunciation for these alams to alert the power operators in the new control room. 
4. Does the PROPOSED CHANGE or DISCOVERY increase the consequences of a malfunction of equipment Important to Safety previously evaluated in the safety basis?

\section{[x] No [] Yes/Maybe}

Basis: As in questions 2 and 3 above, the DCS avoids being the primary means of control or annunciation of any Safety Class 1 or 2 components or systens.

5. Does the PROPOSED CHANGE or DISCOVERY create the possibility of an accident of a different type than any previously evaluated in the safety basis?

\section{[x] No [] Yes/Maybe}

Basis: Reference the Preliminary Hazard Analys is (PHA) performed in section 9 of WHC-SD-610-PSAR-002 revision 1. A 1 ist of PFP SAR sections that were reviewed need to be changed by ECN are attached.

6. Does the PROPOSED CHANGE or DISCOVERY create the possibility of a malfunction of equipment Important to Safety of a different type than any previously evaluated in the safety basis?

\section{[x] No [] Yes/Maybe}

Basis: The possible adverse affect to any Safety Class equipment was in the form of the Safety Class 1 barriers in the form of exterior walls and interior floors requiring core drills to route electrical conduit through as part of project construction. This was not addressed in the Project PSAR but covered by an ICF-XH Design Verification Record of calculation CR-1387-C-01 performed on core bore holes in the Safety Class 1 concrete walls and floors of Buildings $234-5 Z$ and 2736-ZB as required by the project design media. The conclusion of the calculation and its verification was that core borings are acceptable as described in the design media provided no reinforcing steel is cut. All core drills that were done followed the core drill permit criteria which included pre scanning of all walls and floors so as to avoid reinforcing steel or imbedded electrical or fluid carrying steel piping.

7. Does the PROPOSED CHANGE or DISCOVERY reduce the margin of safety as defined in the basis for any Technical Safety Requirement?

\section{[X] No [] Yes/Maybe}

Basis: This project does not modify equipment identified in the TSR.

8. Does the PROPOSED CHANGE or DISCOVERY require a new or revised Technical Safety Requirement?
[x] No
[] Yes/Maybe

Basis: This project does not address TSR equipment. 


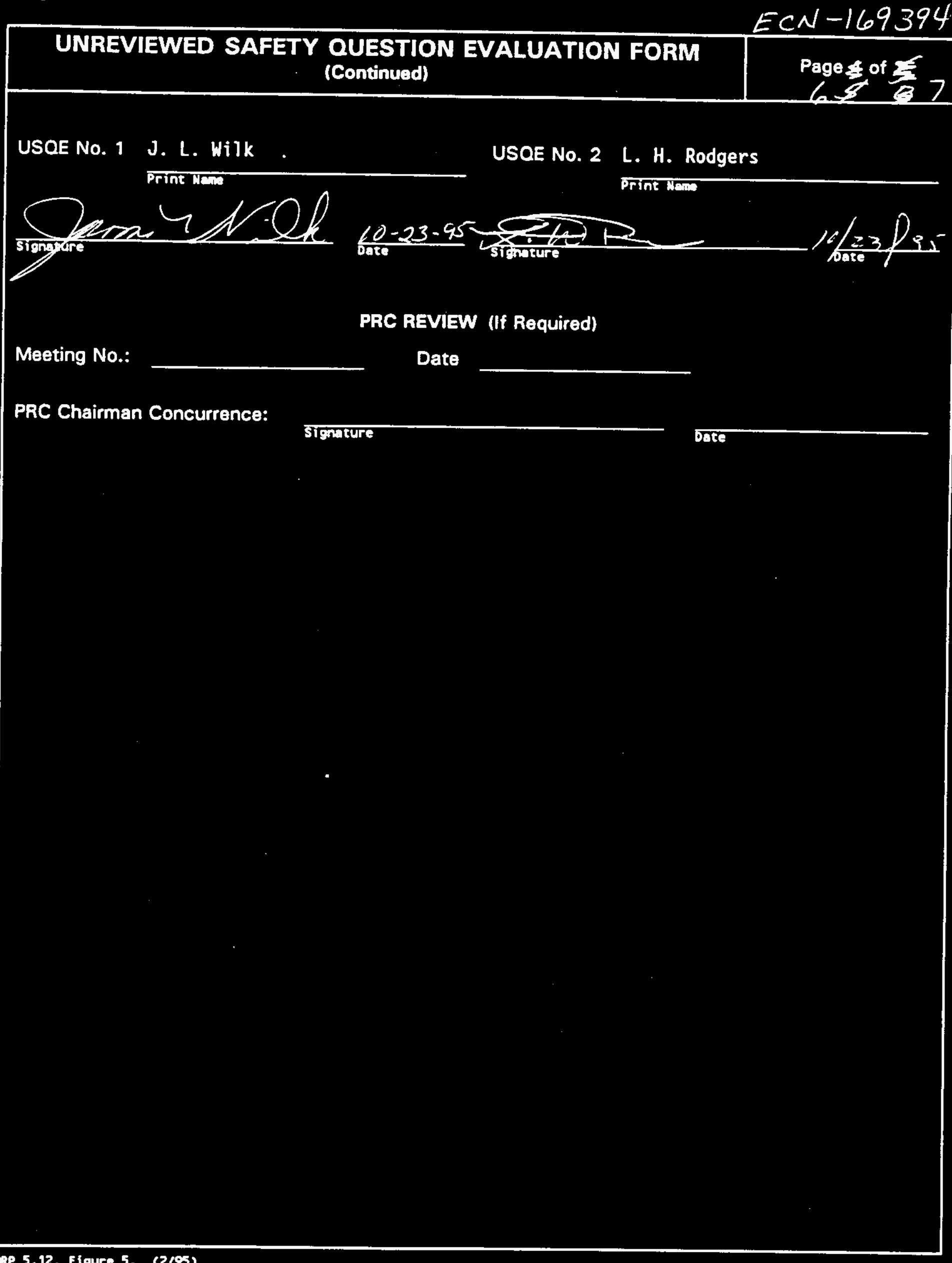


USQ NUMBER PFP-95-30, PROJECT 8-610, "PFP INSTRUMENT UPGRADE"

The following are FSAR sections that will need rewrites or redraws due to the modifications caused by Project B-610:

\begin{tabular}{|c|c|c|}
\hline Fig 5.2-5 & 5.2 .3 .7 .3 & Fig $5.4-2$ \\
\hline 5.4 .1 .1 .2 & 5.4 .1 .1 .3 & 5.4 .1 .1 .6 \\
\hline 5.4 .1 .1 .7 & 5.4 .1 .2 .1 & 5.4 .1 .2 .3 \\
\hline 5.4 .2 .1 .10 & 5.4 .5 .2 & 5.4 .10 .1 .6 \\
\hline 5.4 .10 .2 .2 & 5.4 .11 .2 .4 & 7.2 .1 .1 .5 \\
\hline 7.2 .1 .4 .4 & 8.5 .2 .5 & $9.1 .5 \mathrm{~A} .2 .1$ \\
\hline 9.1 .7 A.1.1 & $9.1 .7 \mathrm{~B} .1 .4$ & 9.1 .7 C.1.1 \\
\hline $9.1 .7 C .1 .3$ & $9.1 .7 C .2 .1$ & $9.1 .7 C .2 .2$ \\
\hline $9.1 .7 C .2 .3$ & 9.1 .70 .2 .1 & $9.1 .7 F .2 .4$ \\
\hline $9.1 .7 F .3 .4$ & $9.1 .7 F .4 .4$ & 9.1 .8 .2 .1 \\
\hline
\end{tabular}

Fig $9.1 .76-1$ Fig $9.1 .70-2$ 


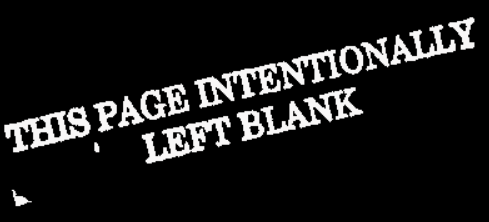




\section{RELEASE AUTHORIZATION}

Document Number: WHC-SD-610-PSAR-002, REV 1

Document Title: Preliminary Safety Analysis Report for Project 89-

GEB-610 Plutonium Finishing Plant Instrumentation Upgrade

Release Date: $\quad 10 / 24 / 95$

This document was reviewed following the procedures described in WHC-CM-3-4 and is:

APPROVED FOR PUBLIC RELEASE

WHC Information Release Administration Specialist:
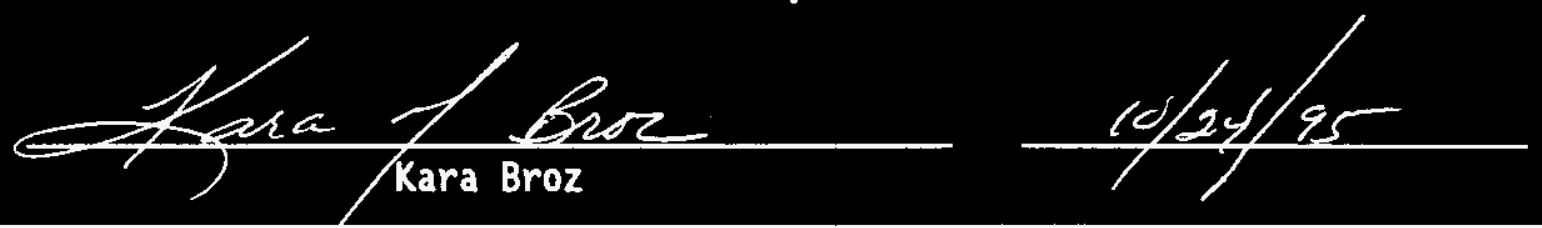

TRADEMARK DISCLAINER. Reference here in to any specific commercial product, process, or service by trade name, trademark, manufacturer, or otherwise, does not necessarily constitute or imply its endorsement, recommendation, or favoring by the United States Government or any agency thereof or its contractors or subcontractors.

This report has been reproduced from the best available copy. Available in paper copy. Printed in the United States of America. To obtain copies of this report, contact:

West inghouse Hanford Company - Document Control Services

P.0. Box 1970, Mailstop H6-08, Richland, WA 99352

Telephone: (509) 372-2420; Fax: (509) 376-4989 


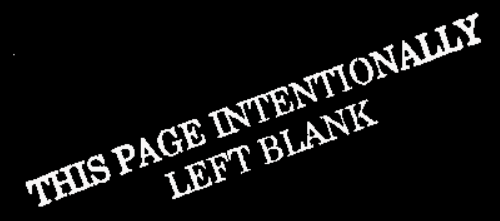




\begin{tabular}{l|l|l|}
\hline 2. Title & 3. Number & Rev No. \\
Preliminary Safety Analysis Report for Project 89- \\
GEB-610 Plutonium Finishing Plant Instrumentation \\
Upgrade
\end{tabular}

7. Abstract

An analysis of the MICON' system upgrade.

8. RELEASE STAMP

OFFICIAL RELEASE BY WHC DATE OCT 241995 Sta 5 
THIS PAGE INTENTIONALLY

LEFT BLANK 
(2) Title

PSAR Project 89-GEB-610 PFP Instrumentation Upgrade CHANEE COUTAOL RECOBO

\begin{tabular}{|c|c|c|c|}
\hline \multirow{2}{*}{ (3) Revision } & \multirow{2}{*}{ (4) Deseription of Change - Replace, Add, and Delete Peges } & \multicolumn{2}{|c|}{ Authorized for Relenee } \\
\hline & & (5) Cor. En?t. & (6) Cor Nor. Date \\
\hline 0 & $\begin{array}{l}\text { (7) Initial release of document }(2 / 26 / 91) \\
E D T-12825,5\end{array}$ & $\begin{array}{l}\text { R. R. } \\
\text { Nearing }\end{array}$ & $\begin{array}{l}\text { J. L. Wise } \\
2 / 26 / 91 / 2\end{array}$ \\
\hline RE 1 & Replace the whole document per ECN -169394 & $\begin{array}{l}\text { E. E. Eseya } \\
\text { Icavan }\end{array}$ & 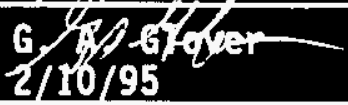 \\
\hline & & & \\
\hline & & & \\
\hline & & & \\
\hline & & & . \\
\hline & & & \\
\hline & & & \\
\hline & & & \\
\hline & & & \\
\hline & & & \\
\hline & & & \\
\hline & & & \\
\hline & & & \\
\hline & & & \\
\hline & & & \\
\hline & & & \\
\hline & & & \\
\hline & & & \\
\hline & & & \\
\hline & & & \\
\hline & & & \\
\hline & & & \\
\hline & & & \\
\hline & & & \\
\hline & & & \\
\hline & & & \\
\hline & & & \\
\hline & & & \\
\hline & & & \\
\hline & & & \\
\hline & & & \\
\hline
\end{tabular}


THIS PAGE INTENTIONALIY

LOFT BLANK 
WHC-SD-610-PSAR- 02 REVI

\author{
PRELIMIMARY SAFETY AMALYSIS REPORT \\ FOR PROJECT 89-6EB-610 \\ PLUTONIUN FINISHING PLANT INSTRUNENTATION UPERADE
}

December 1994 
WHC-SD-610-PSAR-002 REV 1

This page intentionally left blank. 


\section{CONTENTS}

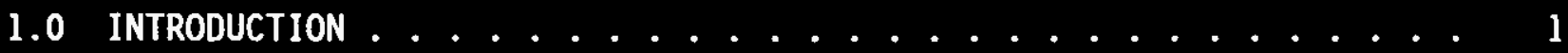

2.0 SUMMARY SAFETY ANALYSIS ............... 5

3.0 SITE CHARACTERISTICS . . . . . . . . . . . . 6

4.0 PRINCIPAL DESIGN CRITERIA . . . . . . . . . . 6

5.0 FACILITY DESIGN . . . . . . . . . . . 6

6.0 HVAC SYSTEMS .................... 7

6.1 COMPARISON .................... 8

7.0 WASTE CONFINEMENT AND MANAgEMENT ............... 11

8.0 RADIATION PROTECTION .......................... 11

9.0 SAFETY ANALYSIS . . . . . . . . . . . . . . 11

9.1 SAFETY ANALYSIS METHODOLOGY .............. 17

9.2 HAZARDS ANALYSIS .................. 18

9.3 SAFETY ANALYSIS ................ 25

9.4 RESULTS AND CONCLUSIONS .................. 31

10.0 CONDUCT OF OPERATIONS ................ 32

10.1 PROCESS MONITORING AND CONTROL ........... 32

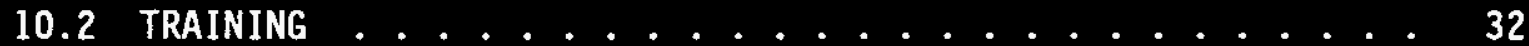

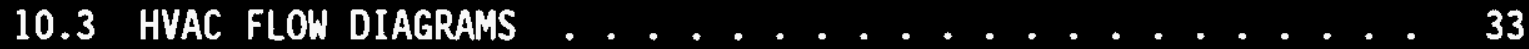

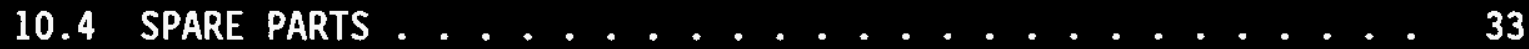

10.5 SOFTWARE CONFIGURATION CONTROL .......... 33

11.0 OPERATIONAL SAFETY REQUIREMENTS .............. 33

12.0 QUALITY ASSURANCE ................... 34

12.1 QUALITY ASSURANCE PROJECT PLAN ........... 34

12.2 PROCESS ENGINEERING WORK PLAN . . . . . . . . . . 34

13.0 TECHNICAL ISSUES REQUIRING FURTHER EVALUATION . . . . . . 34

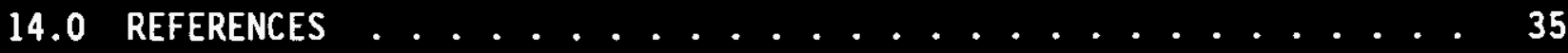

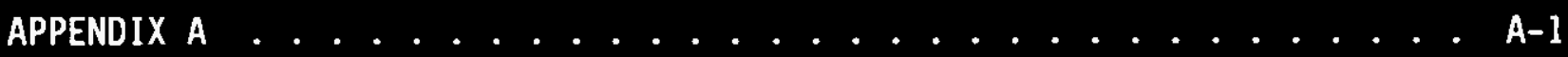




\section{LIST OF FIGURES}

1. Comparison of Existing System to MICONm Automation System. . . . 8

2. MICON Automation System (A/S) Installation. ......... 9

3. Logic Tree. . . . . . . . . . . . . . 20

4. Electrical Power for MiCoNm A/S Computer System. . . . . . . 26

\section{LIST OF TABLES}

1. Analysis of MICON' A/S System Functions Affecting PFP Safety Class 1 and 2 Systems ........... 12

2. Prel iminary Hazard Analys is Construction Activity. . . . . . 22

3. Preliminary Hazards Analysis Part II . . . . . . . . . . . 23

4. Qual itative Accident Severity Levels ............ 25 


\section{LIST OF TERHS}

$\begin{array}{ll}\text { AE } & \text { Architect/Engineer } \\ \text { ALARA } & \text { as low as reasonably achievable } \\ \text { CAM } & \text { cont inuous air monitor } \\ \text { CRT } & \text { cathode ray tube } \\ \text { DBE } & \text { design basis earthquake } \\ \text { DBW } & \text { design basis wind } \\ \text { DCS } & \text { Distributed Control System } \\ \text { DP } & \text { differential pressure } \\ \text { ECN } & \text { Engineering Change Notice } \\ \text { EWS } & \text { engineering work station } \\ \text { FDC } & \text { functional design criteria } \\ \text { GPLI } & \text { general purpose LAN interface } \\ \text { HVAC } & \text { heating, ventilation, and air conditioning (system) } \\ \text { I/O } & \text { input/output } \\ \text { I/P } & \text { current-to-pneumatic (converter) } \\ \text { ICF KH } & \text { ICF Kaiser Hanford Company } \\ \text { LAN } & \text { Local Area Network } \\ \text { LCU } & \text { local control unit } \\ \text { MCC } & \text { motor control center } \\ \text { NEC } & \text { National Electrical Code } \\ \text { NFPA } & \text { National Fire Prevention Association } \\ \text { OCS } & \text { operational control system } \\ \text { OSR } & \text { Operational Safety Requirement } \\ \text { P\&ID } & \text { piping and instrumentation diagram } \\ \text { P/I } & \text { pneumatic-to-current (converter) } \\ \text { PHA } & \text { preliminary hazards assessment } \\ \text { PID } & \text { proportiona] integral differential } \\ \text { PLC } & \text { programable logic controller } \\ \text { PSAR } & \text { Preliminary Safety Analysis Report } \\ \text { QAPP } & \text { quality assurance program plan } \\ \text { RPT } & \text { radiation protection technician } \\ \text { RWP } & \text { radiation work permit } \\ \text { SCS } & \text { supervisor's control system } \\ \text { SWP } & \text { special work permit } \\ \text { UPS } & \text { uninterruptible power supply } \\ \text { WHC } & \text { Westinghouse Hanford Company } \\ \text { WRAM } & \text { Westinghouse radiat ion area management } \\ & \end{array}$


WHC-SD-610-PSAR-002 REV 1

This page intentionally left blank. 


\subsection{INTRODUCTION}

Project 89-GEB-610, "Plutonium Finishing Plant Instrumentation Upgrade," commonly known as B-610, will provide a new distributed control system (DCS) with cathode-ray tube (CRT) operator interfaces. The DCS will have the capacity to monitor and control all instruments and equipment presently connected to the panels in the Power Control Room. The DCS will consist of two CRT-based operator control stations (OCSS), one supervisor's control station (SCS), and one engineering work station (EWS). The EWS shall be located in mobile office M0-016. Separate local control units (LCUS), specifically the MICON Automation System (MICON A/S) U-32 controlier, shall provide monitoring and basic regulatory control. The OCSS, SCS, and EWS and the U-32 controllers will be connected by a communications system. This DCS, now selected, is the MICON" A/S manufactured by MICON" Company of Houston, Texas. The MICONm A/S system will perform event logging, alarm annunciation, process graphics, current and historical data trending, continuous proportional integral differential (PID) control, batch/sequence control, and discrete logic control.

Several additional facility modifications will be performed to accommodate the MICON' A/S. Facility modifications include electrical, civil/ architectural, fire protection, and heating, ventilation, and air conditioning (HVAC) modifications as listed below:

\section{Electrical:}

- Tie into the uninterruptible power supply (UPS-308) to power the MICON' A/S.

- Provide wiring and wireways for interconnection of the MICON" $A / S$ system power, control, and communications.

Additional details of the proposed upgrade will be contained in the Functional Design Criteria (FDC) (Wilk 1994) document.

The existing HVAC control equipment has become operationally and technologically obsolete. The equipment consists of rack-mounted controllers and pen recorders. The MICON A/S will provide a smaller, more reliable electronic microprocessor-based monitor and control systems.

The current control panel layout is inefficient from a human factors viewpoint. The panel layout is not organized in a systematic manner so as to minimize the potential for human error. Observation of the plant parameters is difficult and upset conditions are usually diagnosed after the mishap condition has occurred. Most of the controllers and pen chart recorders mounted in the control panel are 20 or more years $01 d$ and in need of replacement. All trending of HVAC data must be accomplished by comparison and analys is of pen chart recordings and operator-recorded meter readings. This method is tedious and more prone to human error than modern computer-based

${ }^{1}$ MICON is a trademark of Powell Process Systems Inc. 
data processing. Project B-610 complies with DOE Order 6430.1A, dated April 6, 1989, including section 1300-12, Human Factors Engineering.

The MICON" A/S system will provide the type of trend recording and parameter comparisons that will assist the operator and cognizant engineering personnel to better understand, troubleshoot, and control the HVAC system. This upgrade, combined with future additions of instrument loops, can reduce radiation exposure to personnel by lessening the need for personnel to enter radiation areas to obtain data or to control the system. The MICON' $\mathrm{A} / \mathrm{S}$ system will have adequate spare capacity for future expansion.

Construction converting from conventional instrumentation control equipment to a DCS will be accomplished with minimum interruption to facility operations. The construction will be divided into four distinct packages with package three, DCS installation, being further subdivided into three phases. At the end of each package and/or phase a readiness review approval will be required prior to disconnecting old equipment to new construction equipment. (The design schedule will not be held to the construction scenario of packages and phases). The project will be divided as follows:

\section{PACKAGE I}

Package I will complete the necessary modifications to the new men's change room special work permit (SWP) storage area to accommodate the supervisor's and operator DCS consoles.

Power for operating the new DCS will come from the 50-kW UPS (UPS-308) located in room 308 of 234-5Z. The UPS is fed from MCC No. A5, which in turn is fed from the standby power bus in room 266 duct level. The standby power bus switches from normal power to diesel generated standby power if normal power is disrupted. Control room electrical outlets being fed UPS power will differ from normal power outlets to ensure UPS power only supplies UPS designated equipment.

Lighting fixtures will be switched to provide three distinct levels of illumination for the new control room. Lenses will be designed for low surface brightness to minimize glare on the CRT screens of the operator consoles.

Upon completion of the new control room construction, two operator consoles will be positioned according to an agreed upon floor plan. The supervisor's console will be placed in the new supervisor's office.

Full time manning of the new power control room was awaiting acceptance of Project B-680H, "Low Level Waste Treatment Facility" (Kubinski 1992).

\section{PACKAGE II}

Package II will install the remote station to address control and monitoring of the equipment in Projects B-680H and $\mathrm{C}-031 \mathrm{H}$, "PFP Liquid Effluent Facilities." (Kidder 1991) 
A distributed control cabinet having two communications controllers and appropriate input/output (I/0) processing modules (U-32 controllers/ RCM-32s) will be placed in room 45/46 of PRF, with another in building 243-5Z. Control and monitoring for Projects B-680H and $\mathrm{C}-031 \mathrm{H}$ will be via these local controllers. The required conduits physically linking the controller cabinets will be installed to provide UPS power and communicate to the operator consoles through redundant coaxial data highways. Formal refinement and testing of the control algorithms [by Westinghouse Hanford Company (WHC)] has been completed through the operational test sequences for both projects. Full time manning of the new power control was completed upon acceptance of Project $\mathrm{B}-680 \mathrm{H}$.

\section{PACKAGE III}

\section{Phase I, Remaining Controllers and Data Highway}

The remaining five cabinets housing $U-32$ controllers/RCM-32s modules will be installed during Phase I of Package III. The third cabinet will be installed near room 266 in the duct level of 234-5Z. Cabinet four will be located at the east end of the duct level. The fifth and sixth cabinets will be positioned in the former power control room $321 \mathrm{~A}$ on the second floor of 234-5Z. The last U-32 cabinet will be installed in the mechanical equipment room (Room 602) of building 2736-ZB.

Two conduits, one carrying UPS power and the other carrying the redundant general purpose local area network (LAN) interface (GPLI) cables, will run to all seven U-32 controllers/RCM-32s cabinets inside PFP. Also tied into the GPLI data highway will be the two operator consoles and the supervisor's console.

The engineering workstation console will be installed outside the protected area in the plant engineering trailers (MO-016). A single ethernet cable shall connect the workstation to the other consoles housed in the new control room.

At the end of phase I, the operator consoles, U-32 controllers/RCM-32s cabinets and GPLI data highway will be tested for proper operation.

\section{Phase II \& III}

Phases II and III will install the pneumatic-to-electrical converters, pneumatic isolation valves, electrical relays and other devices required to interface the DCS to the existing PFP HVAC and to other systems that require DCS monitor and/or control. Also, all electrical raceways, conduits and instrument wires that carry the signals from the DCS I/0 to the field devices will be installed during this phase. WHC will completely test the appropriate portion of the DCS as applicable to each phase of installation and perform a readiness review. During the review, PFP Operations will confirm the adequacy of the DCS design, installation, testing and outage planning (if required) prior to authorizing the outage for each phase. The discussion of Phases II and III implementation are subdivided by building. 
Phase II, 2736-ZB

The primary task of the U-32 controllers/RCM-32s installed in room 602 is to absorb all $1 / 0$ signals that presently terminate in the existing Allen Bradley programmable logic controller (PLC) located in the same room. The Allen Bradley logic controllers will be removed and the vacant space shall have new terminal strips installed. The controller cabinet will then serve as a termination box for existing field wiring to be connected into the new DCS. The DCS software logic will have been configured to duplicate the PLC ladder logic that controls 2736-ZB HVAC and processes alarms. As each signal wire is transferred to the new DCS, a verification of proper functioning will be conducted for the purpose of discovering and correcting any errors that may have entered the control and monitoring of the building's HVAC. The Architect Engineer (AE) and construction contractor will be responsible for construction up to termination on the DCS, WHC will be responsible for the DCS and its functions. All readouts and alarms will now appear on the consoles now located in the new control room in the new men's change building 234-5ZA. The approximate $\mathrm{I} / 0$ count is 340 discrete inputs, 188 discrete outputs, 120 analog inputs, and 46 analog outputs.

Phase III, 234-5Z

The U-32 controllers/RCM-32s installed in the duct level section of 234$5 Z$ will receive all $I / 0$ adjacent to them. The U-32 controllers/RCM-32s placed in the old power control room second floor will service all I/0 associated with the supply fans, air dryers and other 1/0 that are easily intercepted in room $321 \mathrm{~A}$.

The placement of one U-32 controllers/RCM-32s cabinet near the midpoint of the duct level and one additional unit at east end will give optimum coverage along the length of 234-5Z.

In room 321A, behind the existing power control panelboard, an instrument rack will be attached to the wall facing the rear of the panelboard. Three of the high-pressure current-to-pneumatic (I/P) converters will be mounted on this rack. Other $I / P$ and pneumatic-to-current (P/I) converters and temperature transmitter will be mounted in what is officially named the 26-in. vacuum panel (880 mbar). Control pneumatic tubing leading to the damper motors from the old pneumatic controllers will be transferred to the converters. Conversion of the modulated supply air dampers from pneumatic control to current to pneumatic control will then be complete. The communications controller and its intelligent I/0 (U-32 controllers/RCM-32s), programmed with the appropriate control algorithms, will then assume control of the modulated damper motors. Control and status of the supply and exhaust fan motors, fire panel alarm status and all other readouts and alarms will likewise be transferred.

Approximate input/output count for the all of PFP - not including $1 / 0$ s for Projects B-680H and $\mathrm{C}-040 \mathrm{H}$, "Primary Closed Loop Cooling System For Process Air Compressor and Air Sample Vacuum Pump," (Kubinski 1992) - is 346. 


\section{PACKage IV (Demolition)}

The Allen Bradley PLC equipment will be removed from room 602, 2736-ZB and room 319, 234-5Z. In room 321A all panelboards and attached instrumentation will be removed up to the supply and exhaust fan motor control centers (MCCS).

\subsection{SUMHARY SAFETY AMALYSIS}

A11 equipment and systems controlled or affected by Project B-610 are

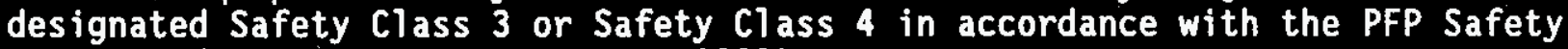
System and Equipment List (Nester 1993).

Based on evaluations and discussions contained in the safety analys is found in Chapter 9 of this document, there are no unresolved safety issues or unacceptable risks associated with the proposed PFP instrumentation upgrade within the bounds of Project B-610. This is substantiated by the following conclusions:

- The risks associated with the construction activities for this project are minimal and acceptable.

- The inventory quantity and distribution is unaffected by the upgrade. Additionally, no potential accidents which could increase the source terms by implementation of this upgrade have been identified.

- The existing instruments in the power control room (e.g. HVAC) can be interfaced to the proposed system; therefore, normal operation capability is unimpaired.

- There are no new hazard/energy sources introduced by the upgrade.

- At a minimum, the upgrade provides equivalent response to abnormal conditions as exists with the current system.

- The use of an existing UPS provides adequate MICON' A/S power supply system reliability in the event of loss of power.

- The ability of systems to respond to accident conditions is unaffected by the proposed upgrade. The existing Safety Class 3 and Safety Class 4 field devices can be monitored or controlled by the MICON' A/S as required without loss of Safety Class system reliability.

- No additional risk is imposed by the upgrade during accident conditions. 


\subsection{SITE CHARACTERISTICS}

Project B-610 involves remodeling and replacing obsolete monitor and control systems with a new microprocessor-based DCS, specifically the MICON' A/S system. Changes will occur in the PFP Power Control Room and 2736-ZB Building. The system shall also assume the control and monitoring responsibilities for Projects B-680H, "Low Level Waste Treatment Facility," and $\mathrm{C}-031 \mathrm{H}$, "PFP Liquid Effluent Facilities." These components and buildings are a part of the PFP Complex. Site characteristics (geography, demography, meteorology, hydrology, geology, and seismology) will not be affected in any way by Project B-610. See Chapter 3.0 of the PFP Final Safety Analysis Report (FSAR) for site characteristics (WHC 1991).

\subsection{PRINCIPAL DESIEN CRITERIA}

Design criteria for PFP are contained in the PFP FSAR, Chapter 4.0 (WHC 1991). The design criteria for Project B-610 are contained in the FDC (Wilk 1994). DOE Order 6430.1A and its referenced codes and standards (DOE 1989) shall regulate the general design of Project B-610.

\subsection{FACILITY DESIEN}

Two operator consoles and the supervisor's console will be installed in the new men's change room facility in building 234-5ZA. The wall that separates the self survey area from the SWP laundry collection area will be moved to the start of the dose control room Westinghouse Radiation Area Management (WRAM) station or approximately 2.4 meters ( $8 \mathrm{ft}$ ) west. About 49.2 square meters (530 $\mathrm{ft}^{2}$ ) of floor space will then exist. Of this, 10.2 square meters (110 $\mathrm{ft}^{2}$ ) will be walled off and serve as the supervisor's office, leaving 29 square meters $\left(420 \mathrm{ft}^{2}\right)$ for the operational power control room. Lighting necessary to meet human factors requirements will be added. A computer grade anti-static carpet will serve as floor covering with sound absorbing panels installed on the wal1s. Normal power and UPS-only outlets will be added per the National Electrical Code (NEC). The existing electrical disconnect, which will tie into the UPS, will provide the power to the UPS outlets via a new UPS panelboard.

The self-survey area will be slightly modified to redirect traffic flow. Structural modifications to any walls will be designed using seismic guidel ines for Safety Class 3 equipment as defined in WHC-CM-1-3, Safety Classification of Systems, Components, and Structures. This mandates the use of SDC 4.1 .

The modifications to transform the former SWP storage area into a new control room and supervisor's office will require relocating existing sprinklers to conform to the room configuration. The design and installation will conform to the requirements of National Fire Protection Association (NFPA) 13 for ordinary hazards occupancy classification.

The existing ventilation system duct work for the change room area will be modified to accommodate the new control room under the PFP new change room 
HVAC upgrade per Project C-038, (Wilk 1994). The HVAC for the new control room will provide a design temperature in control room and office area of $22.2^{\circ} \mathrm{C}\left(72^{\circ} \mathrm{F}\right)$ to $25.6^{\circ} \mathrm{C}\left(78^{\circ} \mathrm{F}\right)$. Voice communication is required between the various control stations. PAX phones and/or intercoms shall be located near the OCSS, EWS, and SCS and at each U-32 controller (or groups of controllers).

The MICON" A/S system electrical power will be supplied from the existing MCC-A5, which is backed up by standby diesel generators. In addition, this power is backed up with a UPS battery that will provide at least five minutes of reserve power. With this uninterrupted power supply, if main power at MCCA5 is lost, the MICON A/S will not see any drop or surge in voltage.

Project B-610 shall be designed to enhance physical access for maintenance, provide for the safety of maintenance personnel and minimize the chances for equipment contamination. Equipment shall be located so that calibrations and repairs can be made by working from floor level. The design of the monitoring and control system shall be as required by the Specification for Process Monitoring and Control System, Project B-610, (Acree 1990). The MICON' A/S monitors and controls 471 Safety Class 3 and 62 Safety Class 4 field devices, all within the 234-5Z complex. See Appendix A for the complete 1ist.

\subsection{HVAC SYSTENS}

No chemical processes will be modified by Project B-610. No field devices will be changed unless they are defective, and then the replacement device will serve the same function. The existing system is simply being replaced by the MICON A/S system.

The existing system is based on single components wired together to form control loops and interlocks. The MICON A/S system uses microprocessor-based multi-loop controllers, which can handle several loops and interlocks at the same time. An example of the difference between the two systems is shown in Figure 1 .

Figure 1 shows a simple tank "pump out" system. Under the existing instrument system, the pump is controlled via a panel mounted on/off switch tied into a MCC. Pump status is shown by an indicator 1 ight. The tank level is indicated using a differential pressure (DP) transmitter and a panel mounted recorder. Flow out of the tank is controlled using a flow transmitter, a panel mounted controller, a I/P and an air-operated valve. In addition, an interlock closes the flow control valve whenever the pump is turned off. This is accomplished by a relay tied to the MCC and a solenoid valve in the air signal line from the converter.

Under the new system, all field signals are wired into termination panels where these analog signals are converted into digital signals and fed to an RCM-32 process controller. The process controller performs the control and interlock functions and feeds commands back to the process via the termination panels. The operator can monitor the process and make changes using either OCS. Information and cominands are passed between the OCS and the RCM-32 controllers using a communication network (see Figure 2). Due to the large computational power of the MICON A/S system, the process controllers and 


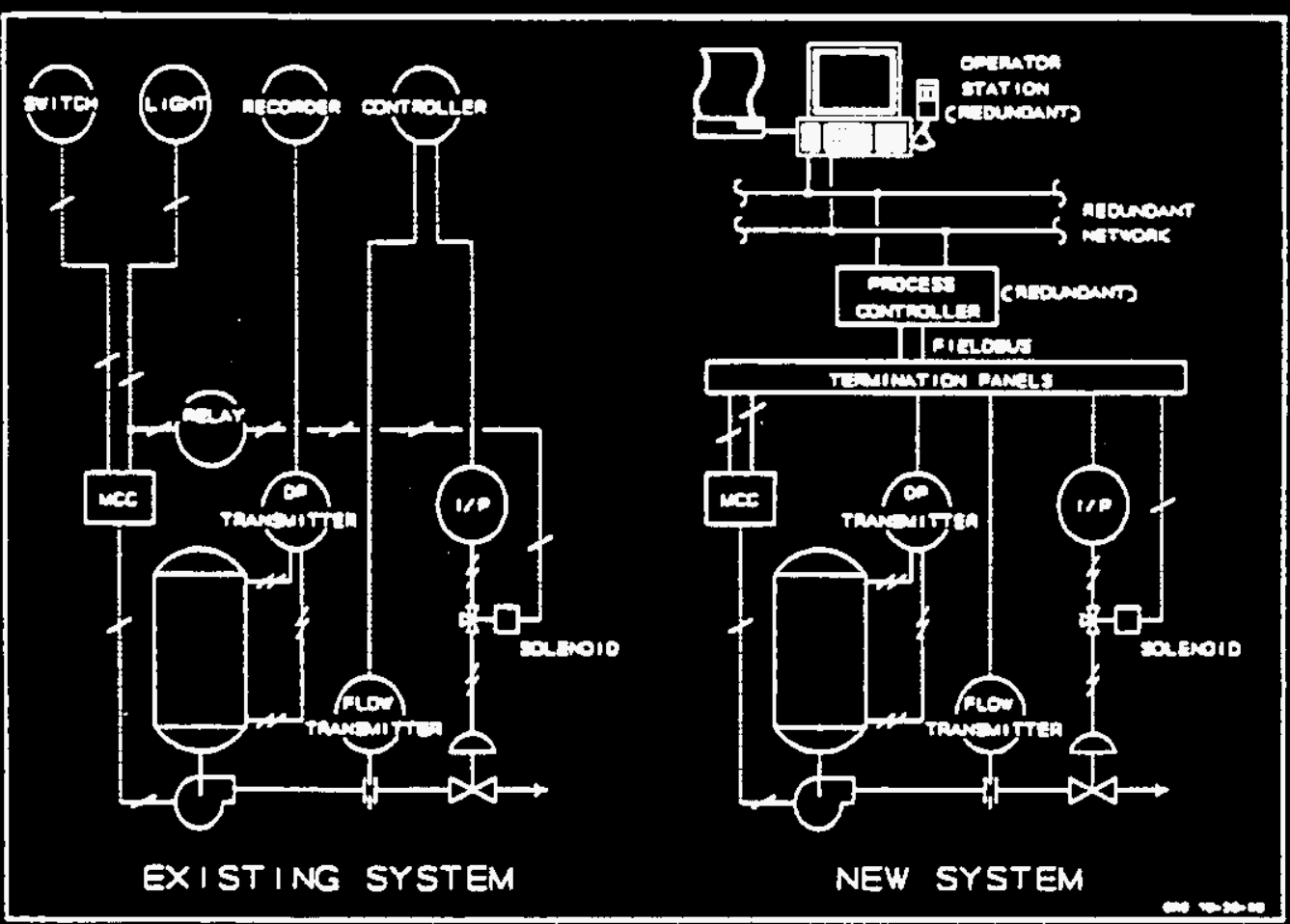

Figure 1. Comparison of Existing System to MICON" Automation System.

workstations can replace hundreds of panel-mounted devices and relays. In fact, the process controller in the example above could accomplish the flow interlock without using the solenoid valve. But this valve is to remain for ease of construction. The valve can be removed at a later date if desired.

\subsection{CONPARISON}

In addition to replacing obsolete equipment, the MICON" A/S system will offer several advantages over the current system:

- Improved Operator Interface: In the existing control room, all instruments are mounted on plate steel panel boards. Originally, these instruments were arranged in a logical order. However, over the years, many changes have been made to the process. Many of the instruments have been removed or placed out of service. Some instruments have been added, but due to the cost of modifying the panel boards, instruments were placed where they would most easily fit, not where they could best be used. As a result, the panelboards are difficult to understand and use.

Under the MICON' A/S system, all process information will be displayed to the operator using two CRTs. Several types of displays will be available to the operator to choose from, including process graphics, instrument groups, trends and historical data, system status, and alarm status. In addition, the CRTs will have windowing capability. This will allow the operator to have multiple displays on one screen. The displays are selected and controlled using a special operator's keyboard 


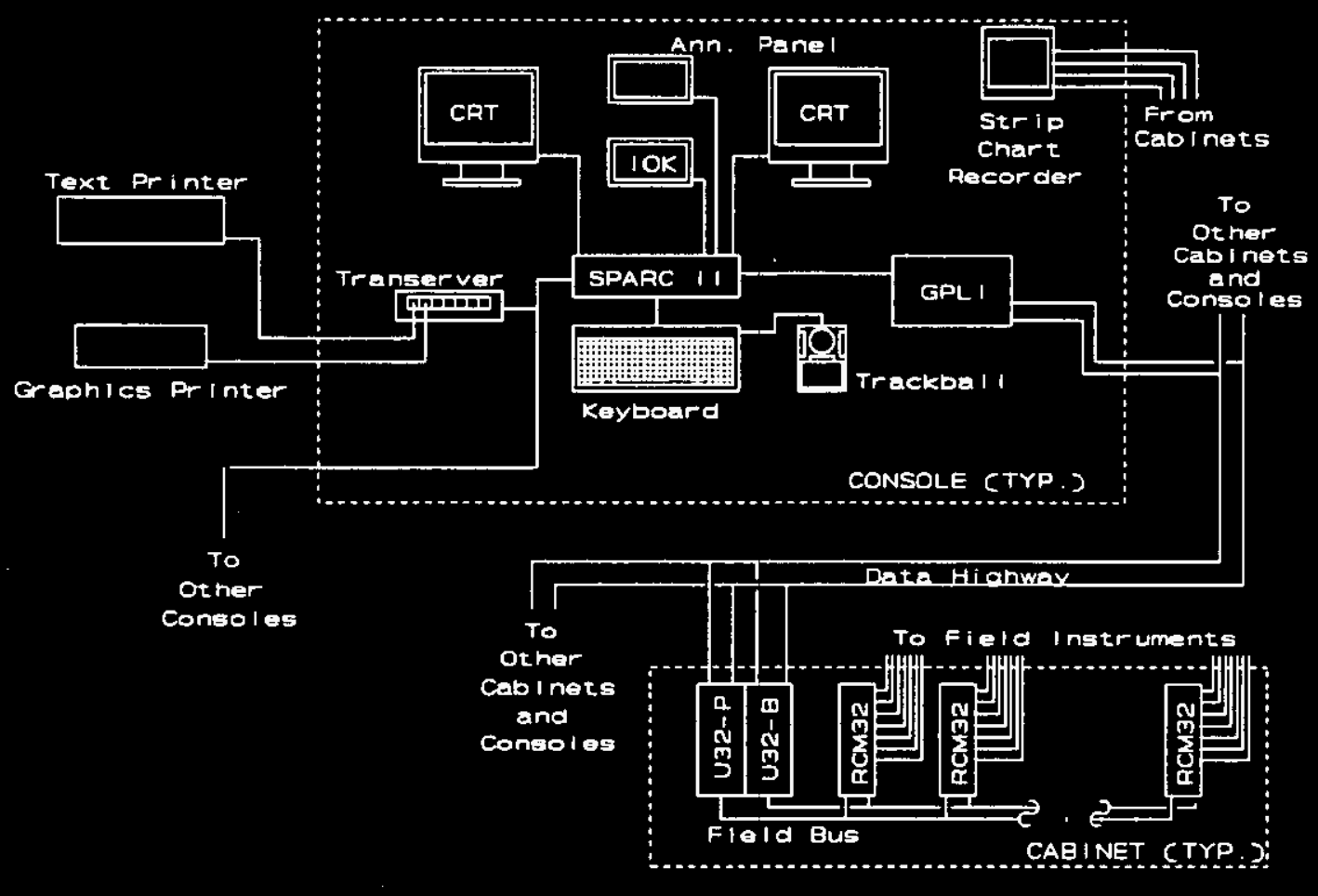

Figure 2. MICON Automation System (A/S) Installation.

and/or mouse. Essential displays can be called up with one or two keystrokes. Also, since these displays are not "mounted in steel" they can be easily changed to suit the needs of the operators.

- Improved reliability: The system presently in use is not redundant and not self-monitoring. Failure of a component will have an immediate effect on the monitored system. Troubleshooting is by trial and error. Repair is done by powering down the affected loop or interlock and replacing or repairing the failed component.

The MICON" A/S is redundant and self-monitoring. Failure of a component, causes switch-over to a backup with no effect on the process. In addition, the system will notify the operator that a fault has occurred and often identify the failed component. Since the backup component is now in control, the failed component can be powered down and repaired or replaced without affecting the monitored system.

Loss of electrical power to the MICON' A/S system is mitigated by barriers to provide acceptable levels of risk. These barriers consist of UPS providing backup power both within the $p l$ ant and within the MICON" A/S system, of emergency generators in $2721-Z$ providing backup power and of steam driven exhaust fans providing emergency backup exhaust for PFP. 
- Improved Flexibility: Any changes in the existing system require the purchase and installation of new components. For example, assume that a low-level pump cutoff is to be installed on the system shown on Figure 1. To do this, an alarm switch and another relay would have to be purchased. The switch and relay would then have to be wired into the level indication loop and the MCC. The alarm switch would al so have to be calibrated. The expense of putting in a change involving the switch and relay may exceed any benefit the change may bring. Once the change has been made, the new switch and relay are costly to remove if they prove to be ineffective or create unforseen problems.

Since changes to the MICON' A/S system are accomplished by software, changes are much less expensive and easier to do. In the above example, the addition of a low-level interlock would require only 15 to

30 minutes of configuration time. If the change needs to be deleted, it can be done in a matter of minutes by downloading the previous version of the configuration.

- Improved Handling of Engineering Data: Collection of engineering data is currently done by hand. The data is copied from $l o g$ sheets or strip charts and hand entered into a personal computer for analysis.

The MICON A/S system will allow data to be downloaded into a DOS compatible file for direct loading into many personal computer programs. This will reduce operator error and data collection time.

- Improved Quality Assurance: Verification of the existing control system configuration requires the field to perform this function. All components and wiring must be located and field traced to ensure accuracy. This is time consuming and costly.

Verification of the MICON" A/S system configuration is done at a workstation and consists of comparing an approved file containing the configuration against the configuration in the system. This is accomplished by comparing the configuration displays against each other.

- Security for the MICON A/S system: To modify the new MICON A/S system configuration, three criteria must be met: (1) the person performing the change must have been trained on how to change the system configuration; (2) the person performing the change must understand the configuration for the area they wish to change; and (3) the person performing the change must have password access to the system. Generally, only a handful of people will meet these criteria. Even if a person is able to make the change, the system will alert the operator of the change via the system $\log$ printer. The existing relay/hardware system, on the other hand, can be bypassed by a person with little training using only a screwdriver and a piece of wire. Once made, these bypasses are difficult to detect and track down. 


\subsection{MASTE CONFINEMENT AND MANAGENENT}

Radioactive wastes are not expected to be generated during Phase I and Phase II construction activities. Normal waste disposal practices by ICF Kaiser Hanford (ICF KH) and WHC will ensure that all construction wastes are disposed of properly.

A special Radiation Work Permit (RWP) will be written, reviewed and approved that will dictate the work requirements in radiation zones. A Radiation Protection Technician (RPT) will be assigned to take air samples, smears and monitor for radiological contamination. Temporary barriers can be erected to control airborne contamination and control the spread of construction dust. Uncontaminated excess equipment will be surplussed.

The confinement, collection, control, and disposal of radiological waste will be strictly by written and approved procedures and plans that will be finalized prior to construction.

Airflows through the HVAC system will not be changed and pressure differentials will be maintained in order to preserve the existing flow patterns.

\subsection{RADIATION PROTECTION}

The radiological control program defined in $\mathrm{MHC}-\mathrm{CM}-1-6$ (WHC 1993) is used at PFP. The as-low-as-reasonabiy-achievable (ALARA) policy will be practiced. Chapter 8.0 of the PFP FSAR (WHC 1991) details the radiation protection for the PFP complex, which includes PRF.

\subsection{SAFETY ANALYSIS}

WHC requirements and procedures for conducting a safety analys is are given in the Nonreactor Facility Safety Analysis Manual (WHC 1993). This involves primarily an evaluation of risk associated with implementation of the project. Risk acceptance criteria are specified in Section 7 of this manual (WHC 1993). This upgrade will not change the toxicological or radioactive material inventory in the PFP complex. Table 1 was compiled to demonstrate that the chemical processes will not be modified and that there are no control interfaces (direct or indirect) between 8-610 and PFP Safety Class 1 and 2 equipment (Wilk 1994). Table 1 was assembled from the Safety Class assignments in WHC-SD-CP-TI-108, Rev. 13 (Nester 1993), and from the MICON" A/S system functions set forth in WHC-SD-610-TI-001 (Silvan 1994). The existing system, as discussed in Section 6 of this document, is simply being augmented by the MICON". The existing system is currently operated at a level of acceptable risk when associated with the existing HVAC system. Therefore, this Preliminary Safety Analysis Report (PSAR) focuses on assessing any potential increases to risk of operating the facility posed by Project B-610. Since the HVAC system is not changed, the impact or consequences of a credible accident will not be increased as a result of this upgrade. 
Table 1. Analys is of MICON' A/S System Functions Affecting PFP Safety Class 1 and 2 Systems. (5 sheets)

\begin{tabular}{|c|c|c|c|c|}
\hline $\begin{array}{c}\text { SEt reference } \\
\text { number }\end{array}$ & Safety Class lists & Status of class & 8610 address to system & $\begin{array}{c}\text { Change to } \\
\text { safety class } \\
\end{array}$ \\
\hline \multicolumn{5}{|c|}{ Safety Class 1} \\
\hline 1.1 & suilding structural & Firm & $\begin{array}{l}\text { None, however, see text where seismic responses } \\
\text { are addressed. }\end{array}$ & Mone \\
\hline 1.2 & Pu storage & Firm & None & Wone \\
\hline 1.3 & $\begin{array}{l}\text { HVAC supply fan seismic shutdoun } \\
\text { system }\end{array}$ & Firm & & \\
\hline 1.3.1 & Accelerograph & firm & $\begin{array}{l}\text { Light indication that accel room } 11 \text { bypassed } \\
\text { Light indication that accel rocm } 12 \text { bypessed } \\
\text { Light indication that power on -- accel room }\end{array}$ & $\begin{array}{l}\text { Indication } \\
\text { only. Will not } \\
\text { alter safety } \\
\text { classification. }\end{array}$ \\
\hline 1.3 .2 & $K 1 \& K_{2}$ & Firm & Mone & None \\
\hline 1.3 .3 & Circuits and conduits & firm & Mone & Mone \\
\hline 1.3 .4 & Undervolt reloys & firm & Mone & Mone \\
\hline 1.3 .5 & $\begin{array}{l}\text { 480v switch gear circuit } \\
\text { breakers in roonh } 266\end{array}$ & firm & Mone & Mone \\
\hline 1.4 & UPS seismic shutdoun & Candidate & $\begin{array}{l}\text { Ups alarm indicating that ET-8/9 ups trouble. } \\
\text { Light indicating that UPS } 1 / 2 \text { is on line. } \\
\text { Light indicating seimic alarm al arming. } \\
\text { Light indicating seismic detector on line. }\end{array}$ & $\begin{array}{l}\text { Indication } \\
\text { only. Nill not } \\
\text { alter safety } \\
\text { classification. }\end{array}$ \\
\hline 1.5 & MT5 & Firm & & \\
\hline 1.5.1 & $\begin{array}{l}\text { Manual emergency shutdom } \\
\text { switch, MS-5-E }\end{array}$ & Firm & Wone & Mone \\
\hline 1.5 .2 & Contactor $\mathrm{AY}-5-1$ & Firm & None & None \\
\hline 1.5 .3 & Tenperature control IIC-5." & Firm & None & Mone \\
\hline 1.5 .4 & Process alarm RID inout TAS.5." & Firm & Mone & Mone \\
\hline 1.5 .5 & Relays JY-5-0 & firm & Mone & None \\
\hline 1.5 .6 & Start relay $J Y-5-{ }^{*} \mathrm{C}$ & Firm & None & Mone \\
\hline
\end{tabular}


Table 1. Analysis of MICON A/S System Functions Affecting PFP Safety Class 1 and 2 Systems. (5 sheets)

\begin{tabular}{|c|c|c|c|c|}
\hline $\begin{array}{c}\text { SEL reference } \\
\text { number } \\
\end{array}$ & Safety Class lists & Status of $\mathrm{class}$ & B610 eddress to system & $\begin{array}{l}\text { Change to } \\
\text { Safety Class }\end{array}$ \\
\hline $\begin{array}{l}1.5 .7 \\
1.5 .8\end{array}$ & $\begin{array}{l}\text { Contactor JY-5-*E } \\
\text { SS reloy JY-5-**F }\end{array}$ & $\begin{array}{l}\text { Firm } \\
\text { Firm }\end{array}$ & $\begin{array}{l}\text { None } \\
\text { Mone }\end{array}$ & $\begin{array}{l}\text { None } \\
\text { None }\end{array}$ \\
\hline 1.6 & $\begin{array}{l}\text { 26-in. vacum ( } 880 \text { mbar) liquid } \\
\text { detector \& interlock }\end{array}$ & Firm & & \\
\hline 1.6.1 & $\begin{array}{l}\text { Liquid detectors LD-PVLDL- } \\
001 / 002\end{array}$ & Firm & $\begin{array}{l}\text { IK1 relay leak detect alarm } \\
\text { 2K1 relay leak detect alarm } \\
\text { IK2 reloy Lo failure alarm } \\
\text { 2K2 reloy LD failure alarm } \\
\end{array}$ & $\begin{array}{l}\text { Indication } \\
\text { only. ulll not } \\
\text { olter safety } \\
\text { classification. }\end{array}$ \\
\hline 1.6 .2 & system Miring & firm & None & None \\
\hline 1.6 .3 & Relays 1/2 LOI & firm & See 1.6.1 & See 1.6.1 \\
\hline 1.6 .4 & .5 of $\mathrm{KI}$ relay & Firm & See 1.6.1 & See 1.6.1 \\
\hline 1.6.5 & $\begin{array}{l}3 \text { way sol valve } \\
\text { EY-PYLDL-1/2 }\end{array}$ & Firm & EW-SV-4 solenoid silencer tank drain & $\begin{array}{l}\text { Wone - not the } \\
\text { seane device }\end{array}$ \\
\hline 1.6.6 & Dov control & Firm & See 1.6 .5 & $\sec 1.6 .5$ \\
\hline 1.7 & HEPA filter (exc 2322) & Candidate & 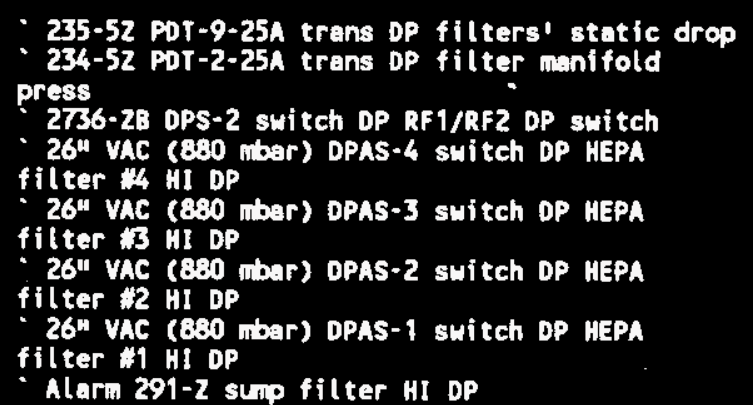 & $\begin{array}{l}\text { Mone - alt are } \\
\text { input to the } \\
\text { micowim A/s } \\
\text { system. None } \\
\text { are used for } \\
\text { control. }\end{array}$ \\
\hline
\end{tabular}


Table 1. Analys is of MICON A/S System Functions Affecting PFP Safety Class 1 and 2 Systems. (5 sheets)

\begin{tabular}{|c|c|c|c|c|}
\hline $\begin{array}{c}\text { SEL reference } \\
\text { nuber }\end{array}$ & Safety Class lists & Status of class & B610 address to system & $\begin{array}{c}\text { Change to } \\
\text { Safety class }\end{array}$ \\
\hline 1.8 & Stack mon equip 296-2-1 & Candidate & $\begin{array}{l}\text { Alarm } 291-21 \text { stack CAM failure } \\
\text { Alarm } 291-2 \text { stack pump faiture } \\
\text { Alarm } 291-2 \text { stack CAM }\end{array}$ & $\begin{array}{l}\text { Alarm only. } \\
\text { Uill not aiter } \\
\text { safety classi- } \\
\text { fication. }\end{array}$ \\
\hline 1.9 & stack non equip 296-2-3 & Candidate & - Alarm 241-Z/2\%6-28 stack CAN & $\begin{array}{l}\text { Alarm only. } \\
\text { Uill not ai ter } \\
\text { safety classi- } \\
\text { fication. }\end{array}$ \\
\hline 1.10 & stack mon equip 296-2-5 & Candidate & $\begin{array}{l}\text { Alarm } 2736-28 \text { stack CMM failure } \\
\text { Alarm } 2736-28 \text { stack CNM failure } \\
\text { Alarm } 2736-28 \text { stack CN A }\end{array}$ & $\begin{array}{l}\text { Alorm only. } \\
\text { Uill not aiter } \\
\text { safety classi- } \\
\text { fication. }\end{array}$ \\
\hline 1.11 & Stack mon equip 296-2-6 & Candidate & - Alarm 2736-2A CAM failure & $\begin{array}{l}\text { Alarm only. } \\
\text { Will not aiter } \\
\text { safety classi- } \\
\text { fication. }\end{array}$ \\
\hline 1.12 & stack mon equip 2\%-z-14 & Candidate & - Alarm 232-2 stack CAM A/F & $\begin{array}{l}\text { Alarm only. } \\
\text { Uill not alter } \\
\text { safety classi- } \\
\text { fication. }\end{array}$ \\
\hline \multicolumn{5}{|c|}{ Safety Class 2} \\
\hline 2.1 & MEPA filter $232 z$ & Candidate & Mone & None \\
\hline
\end{tabular}




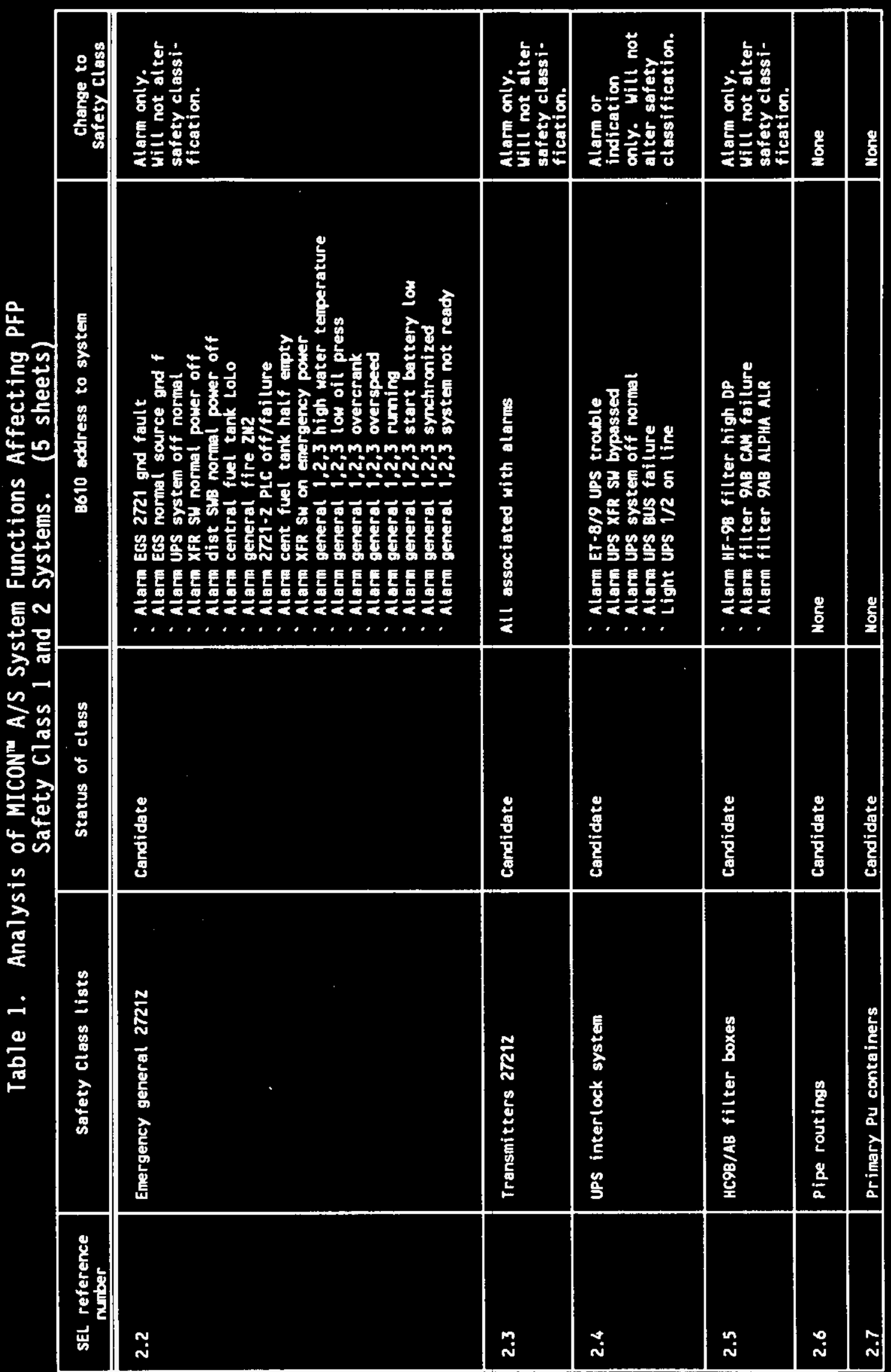


WHC-SD-610-PSAR-001 REV 2

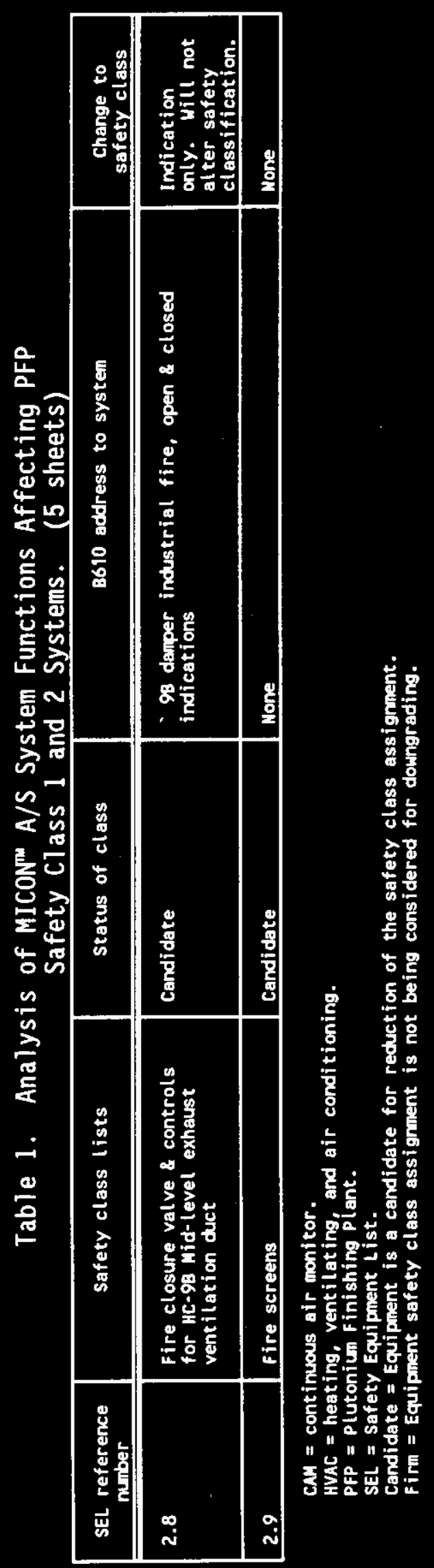


The scope of this assessment addresses the project upgrades as detailed in WHC-SD-610-FDC-001, Rev. 5 (Wilk 1994). Based on a review of these documents and discussions with PFP engineers, the following systems are the main ones being significantly impacted by this upgrade:

- PFP Ventilation Systems

- PFP Liquid Low-Level Waste System and 236-Z/291-Z Closed-Loop Cooling System

- Electrical Power System

- Steam System

- Water System

- Dry Air

- Instrument Air

- Vacuum Systens

- CAM Monitoring System (stack and room).

The installation of the MICON" A/S system involves 694 indicating signals to and from the systems noted above. Most of these will be for the purposes of alarming, data readout, or indication. The remainder would be for control. Nearly all of these connections are duplicates of existing, retained indication/control systems and provide a centralized location from which to perform control based on indications.

This study addressed only those systems that would have an impact on the risk of building operations as addressed in the $Z$ Plant FSAR. The study did not address the impact of addition of the MICON A/S system to the B-680H or $\mathrm{C}-040 \mathrm{H}$ installations. The risk of operation of these systems was addressed in a separate PSAR. Although the MICON" A/S system did duplicate the indication/control of these systems it was not considered necessary to repeat the risk study.

\subsection{SAFETY ANALYSIS HETHODOLOGY}

The safety analysis process, applied to the replacement of selected existing instrumentation and control systems with the MICON A/S, consists of two parts:

1. Preparation of a preliminary hazards analysis (PHA) to identify and qualitative evaluate hazards of a potential concern to the change out of the selected instrumentation and control modules.

2. Preparation of a hazard analys is based on screening the PHA for accidents of significant category level, either probability category or severity category. Other accidents that may require defense of the selected category level may also be addressed. 


\section{2 hazaRas aNALYSIS}

The FDC specifies that the task will be divided into five packages:

- Construct a new control room within the new men's change room SWP storage area

- Place three new consoles with ancillary equipment in that new control room

- Place six new distributed control cabinets to perform control and monitoring of existing, installed, or to-be-installed equipment in the 234-5z complex. This includes equipment acquired through Project B-610, Project C-040H, "Primary Closed Loop Cooling System For Process Air Compressor and Air Sample Vacuum Pump, " in the 291-Z building, Project C-171, "291-Z Process Air Compressors, (Wilk 1992)" Project B-680, "PFP Liquid Low Level Waste System Modification, " and Project C-031H, PFP Liquid Effluent Treatment Facilities

- Install the new controllers (MICON' $A / S$ ) and instrument tie-ins in the new cabinets within the 234-5Z and 2736-ZB buildings

- Perform demolition on the existing control equipment in the 2736-ZB building.

\subsubsection{Replacement of Existing Control System with nICoN" A/S}

9.2.1.1 Preliminary Hazard Analysis. A PHA was performed for replacing the existing control system with the MICON A/S. The purpose of this analysis was twofold: first, to identify the presence of any hazardous materials and conditions associated with the upgrade, and second, to qualitatively evaluate any identified hazards. namely:

Hazards were identified through a combination of document reviews,

- WHC-SD-610-TI-001, Rev, 5, B610 PFP Instrument Upgrade (PFP HVAC Control Room Update) (Silvan 1994).

- WHC-SD-CP-SAR-021, Rev, 0, Plutonium Finishing Plant, Final Safety Analysis Report (WHC 1991).

- HHC-SD-CP-PSAR-005, Rev. 0, Preliminary Safety Analysis Report for Projects 90L-ENB-680H and 91G-GEC-040 (Kubinski 1992).

- The following Engineering Change Notices (ECNs) were those prepared against the HVAC flow diagrams which define the equipment functions in the buildings:

- ECN 198206 (Drawing H-2-96418)

- ECN 198207 (Orawing H-2-46884)

- ECN 198208 (Drawing $\mathrm{H}-2-80167$ )

- ECN 198209 (Drawing H-2-23400)

- ECN 198210 (Drawing H-2-815178)

- ECN 604944 (Drawing H-2-26089). 
The PFP FSAR (WHC 1991) utilized a fault tree (Figure 9.0.2-1 in WHC 1991), which is included as Figure 3 in this text, to find those accidents or upsets which were to be more extensively evaluated. The FSAR did not utilize a PHA.

Following the review of the documentation, the safety analyst proceeded with preparation of a PHA. A PHA session was held which included the cognizant engineer, an independent safety representative, an operations representative, and selected personnel experienced in operating the MICON" $A / S$ system.

Safety Class designations were examined, but are not included in the PHA tables. Existing Safety Class systems are currently in place to adequately cross check normal process flow and minimize the risk from abnormal events which may cause the hazard condition. Table 1 demonstrates that the installation of the MICON A/S will be a transparent interface to the existing Safety Class systems, with current hardware interlocks for the identified safety-related systems remaining functional. Plant risk will not be adversely affected.

The resultant PHA tables divide potential hazards into two types. The first type, Table 2, addresses hazards associated with construction. The second type, Table 3, examines those connections from the MICON' A/S system to the existing system which might have impact on the results from the scenarios addressed in the PFP FSAR. Table 2 is divided into five fields:

- Hazard/energy source

- Potential accident and sequence

- Target/potential consequences

- Mitigating barriers

- Engineered/Administrative

- Category level

- Probability category (a-anticipated, u-unlikely, euextremely unlikely, i-incredible)

- Severity category (see Table 4).

other possible hazards identified could result from construction and/or computer failure. These hazards are listed in tabular form in Table 2 and discussed in Section 9.3 of this chapter. 


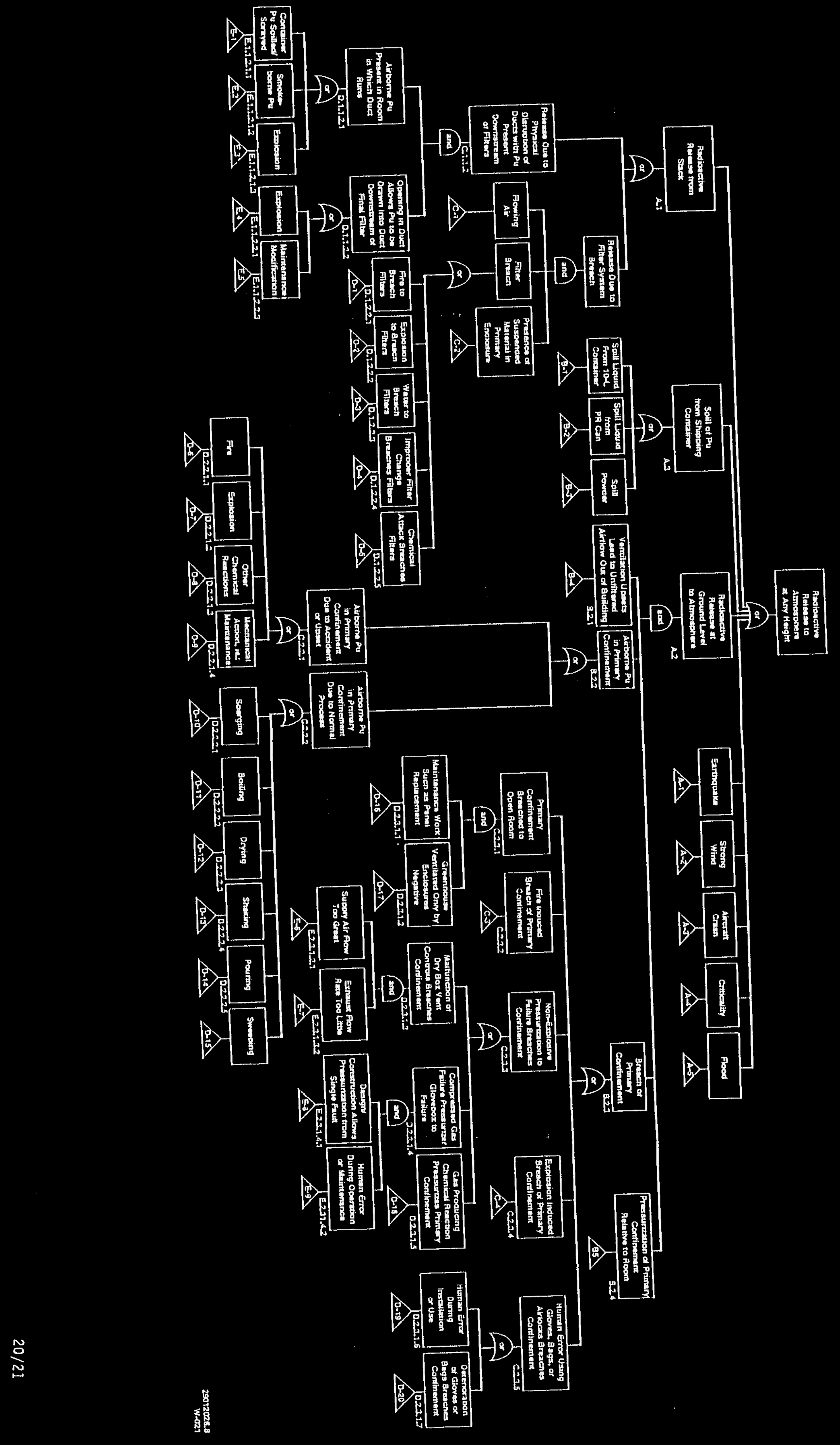

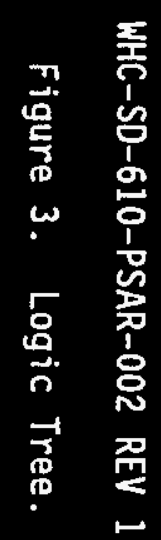




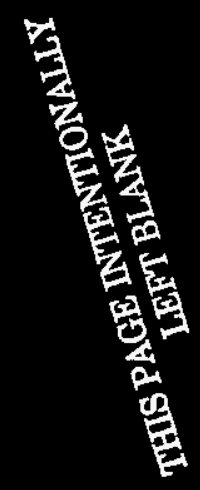


WHC-SD-610-PSAR-002 REV 1

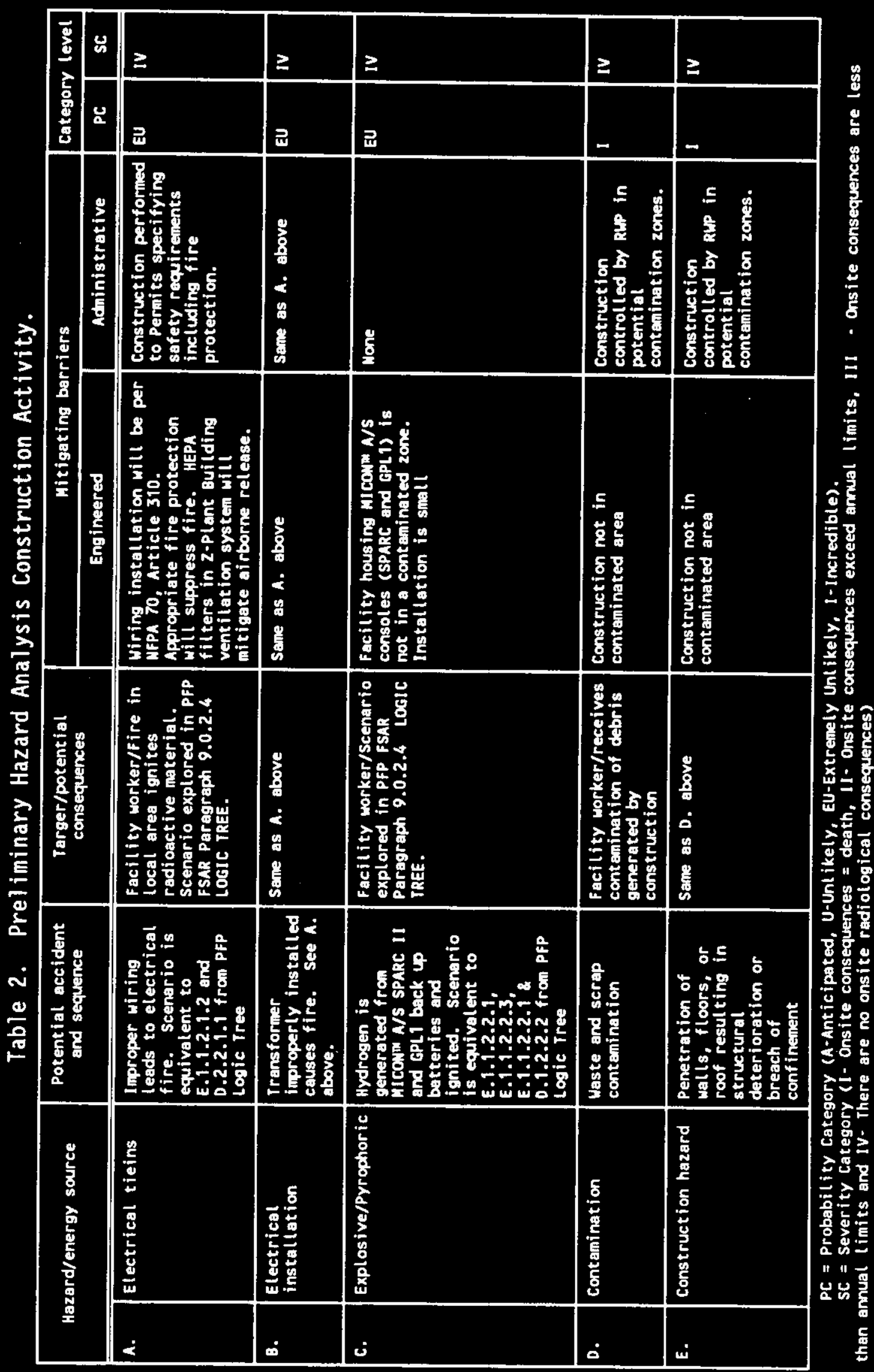


WHC-SD-610-PSAR-002 REV 1

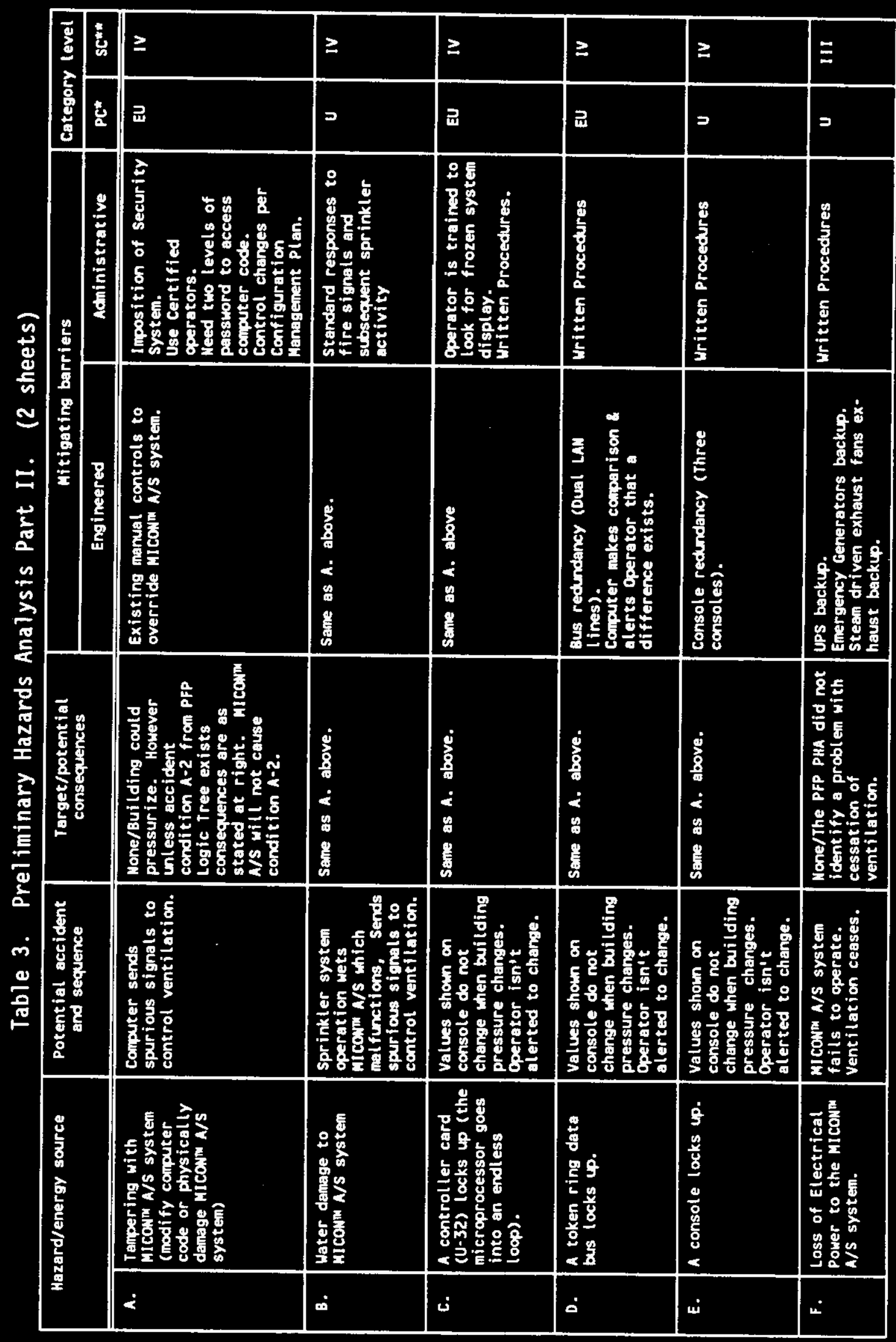




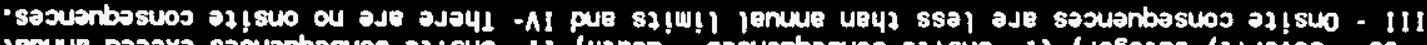

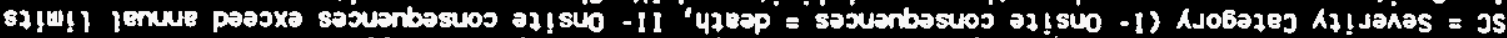

( Olqtpojsul-1 'A

\begin{tabular}{|c|c|c|c|c|c|c|c|}
\hline AI & ng & sojnposodd wo2נ!dn & 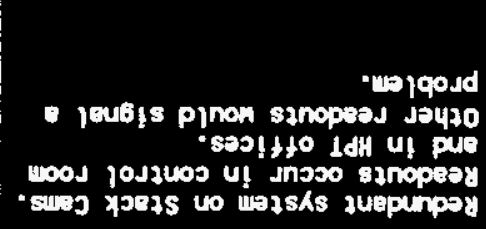 & 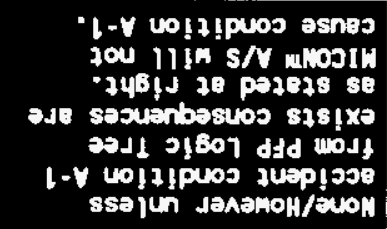 & 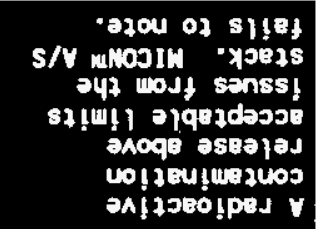 & 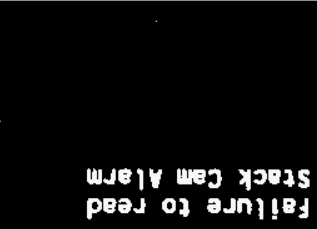 & -н \\
\hline $\mathbf{A I}$ & n & sadnposodd vala!Jn & 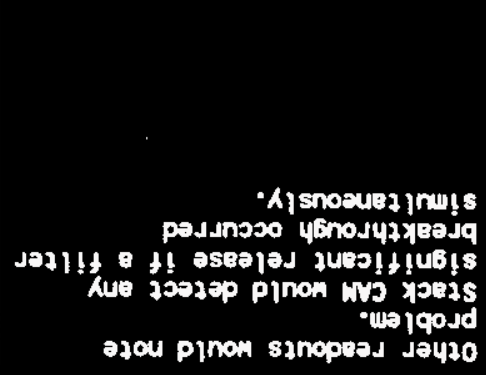 & 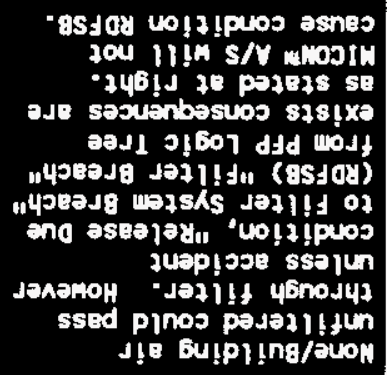 & 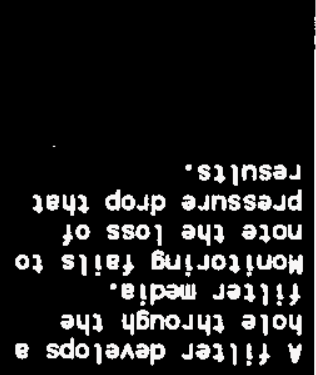 & 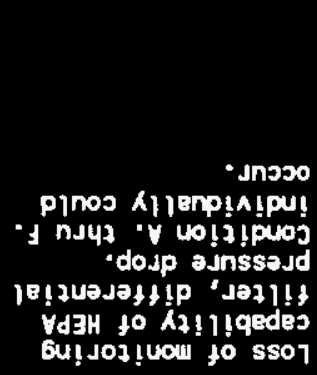 & כי \\
\hline **as & wd & 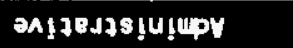 & posezulgug & \multirow{2}{*}{$\begin{array}{c}\text { sasuenbasuos } \\
\text { ge! } 1 \text { uajod/706J01 }\end{array}$} & \multirow{2}{*}{ 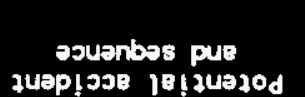 } & \multirow{2}{*}{\multicolumn{2}{|c|}{ әo.jnos A6נaua/PJezBH }} \\
\hline \multicolumn{2}{|c|}{ 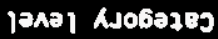 } & \multicolumn{2}{|c|}{ SJa!daeq $64 ! 206 ! z ! H$} & & & & \\
\hline
\end{tabular}

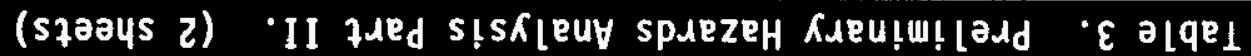


Table 4. Qualitative Accident Severity Levels.

\begin{tabular}{|l|c|c|c|}
\hline \multicolumn{1}{|c|}{ Category } & Onsite & Offsite & Enviromment \\
\hline \hline I & Deaths & Exceed annual limits & Severe impacts \\
\hline III & Exceed amual limits & Below amual limits & Major impacts \\
\hline IV & Below annual limits & Megligible & Minor impacts \\
\hline & Mone & None & $\begin{array}{c}\text { Less than significant } \\
\text { impacts }\end{array}$ \\
\hline
\end{tabular}

\subsection{SAFETY ANALYSIS}

\subsubsection{Loss of Electrical Power to MICON" A/S}

Power to the PFP complex is monitored within the 234-5Z building. Existing connections to the instrument panels are not modified by this project. Figure 4 is a simplified one-line diagram of the current Electrical Distribution System modified to reflect connection to the MICON $A / S$. The emergency bus power and UPS supplied to the MICON" A/S will enhance the current plant capability for controlled HWAC shutdown during events involving a loss of offsite power. The design strategy of separate yet partially redundant power distribution systens not only enhances operational safety, it also helps limit facility recovery time during startup operations following a loss of power event.

The MICON" A/S system cannot damage equipment by transmitting a spurious electrical signal to the U-32 units. The MICON $\mathrm{A} / \mathrm{S}$ cards feature optoisolators for transfer of signals. This prevents an electrical transient, above normal signal strength, from transferring across the opto-isolators and causing damage to downstream components. Loss of electrical power to this MICON $\mathrm{A} / \mathrm{S}$ will not alter the risk associated with plant operations.

\subsubsection{Interface Incompatibility}

No interface compatibility problems exist. It will not be necessary to replace any flow meters or final control devices. This reduces the potential for introduction of equipment with reduced reliability. New I/P and P/I converters and new transmitters with sensing elements will be installed in some instances to enhance compatibility.

\subsubsection{MICON A/S Failure}

The control system will be connected only to Safety Class 3 or 4 (not Safety Class 1 or 2) systems. The imposition of this system will not adversely affect these systems but will improve their functions by allowing state-of-the-art malfunction alarming. State-of-the-art means full adherence to human factors requirements. 
WHC-SD-610-PSAR-002 REV 1

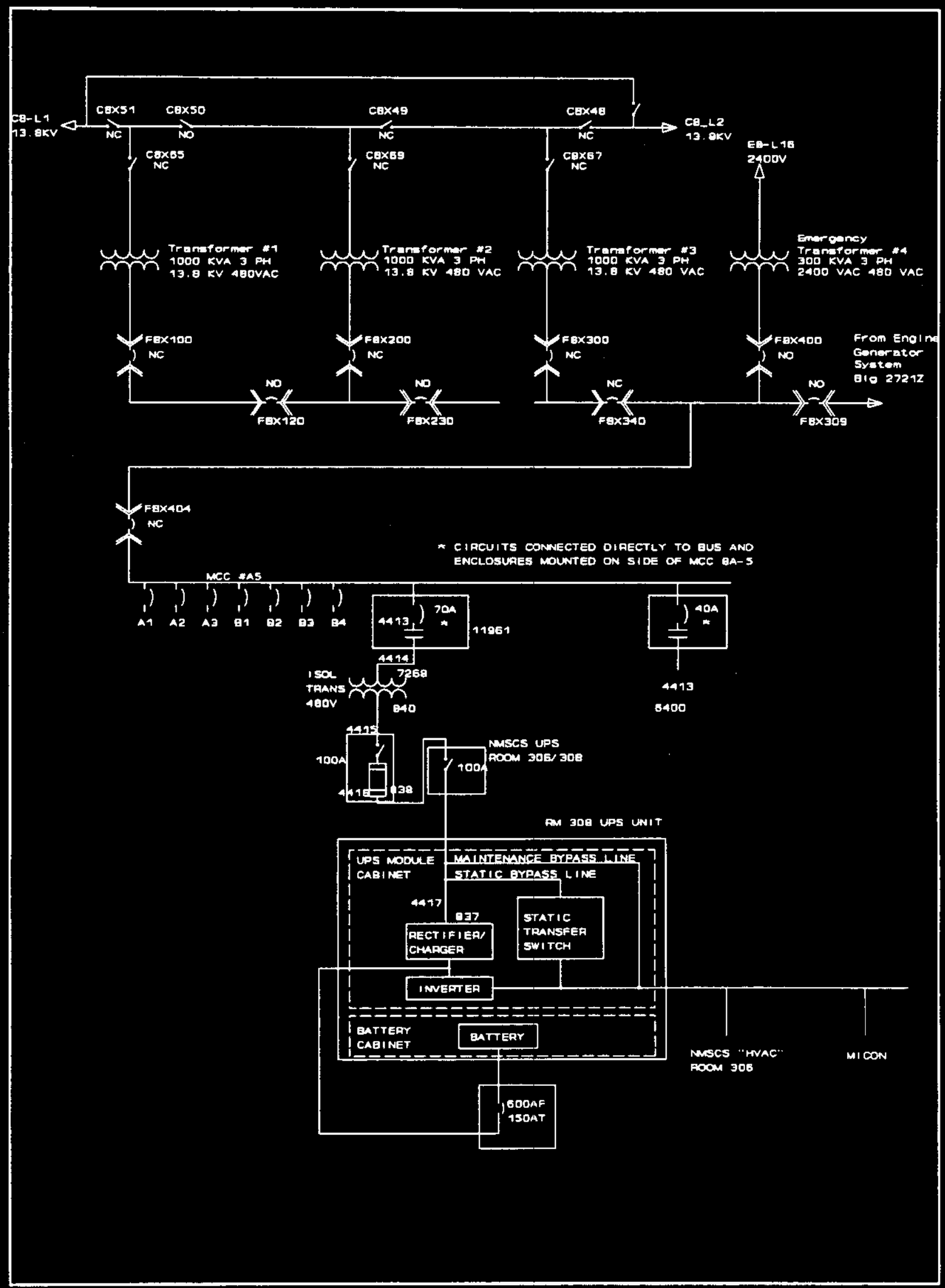

Figure 4. Electrical Power for MICON A/S Computer System. 
The control system assures its own reliability through the use of redundancy in the data highways connecting the OCSs to the LCUs and the use of separate microprocessors for the various process water pumps, vacuum pumps, spray pumps, pressure measurements, and supp1y/exhaust fans in the HVAC etc. The redundancy consists of using two cables to provide the data highway between the OCSs and LCUs. There are several microprocessors dedicated to the HVAC to further redundancy. Therefore, failure of a microprocessor will result in only a minor system disturbance. Redundant failures or a common mode failure is required before a major but still acceptable upset will be experienced. Failure of the MICON' A/S system will not alter the risk associated with plant operations.

\subsubsection{Risks from Accident Conditions}

9.3.4.1 Design Basis Hind. A design basis wind (DBW) striking the facility can cause loss of property, lives, and operating capability. The risk of such a loss was evaluated in the PFP FSAR. Project B-610 does not impact structural capability and therefore is not expected to influence the risk of loss associated with a OBW striking the facility.

The risk to the MICON' A/S system from a DBW is nearly nonexistent as the MICON" A/S is located totally within the existing facility, and thus protected by the existing facility. The control room is within the new men's change room. This was built to Safety Class 3 standards, which specify a design basis wind to have a $70 \mathrm{mph}$ velocity without a wind missile (SDC 4.1, Rev. 12).

9.3.4.2 Seismic Event. Loss of MICON A/S monitoring and control during a DBE poses no additional risk above that currently assessed for the PFP.

Seismic activity will automatically trigger control devices which are intended to minimize process upsets. The MICON $\mathrm{A} / \mathrm{S}$ system adds to this a monitoring capability that assures that the seismic detector is on line and will alarm.

Mitigation of the consequences of a design basis earthquake (DBE) is accomplished by the appropriate structural design of process components and structures and the fail-safe process actions. It is expected (WHC 1991) that substantial process damage results from an earthquake regardless of the control system used. Since the existing control system does not enhance earthquake protection, it is reasonabie to assume that the loss of monitor and control actions of the MICON $A / S$ during a DBE can be tolerated.

9.3.4.3 Upset of the PFP Ventilation Systems. The PFP FSAR identified the $234-5 Z$, the $236-Z$, the $2736-Z$, and the $2736-Z B$ buildings as being susceptible to a ventilation upset consisting of either an excess pressurization or an excess depressurization of the building.

The PFP FSAR concluded that in the $2736-2 B$ building, a release could be manifested if an incredible set of circumstances were to occur, but that the release would have insignificant impact on any onsite or offsite receptors.

As a result of these findings the PFP safety analysis report judged ventilation system components to warrant a Safety Class 3 or 4 rating. 


\subsubsection{An Upset to the PFP Liquid Low Level Waste System and 291-Z Closed} Loop Cooling System. Project B-610 will duplicate the control and monitoring functions for Projects B-680H and C-040.

The PSAR (Kubinski 1992) for Projects B-680H, "PFP Liquid Low Level Waste System Modification," and (Kubinski 1992) C-040, "291-Z Closed Loop Cooling Water System," evaluated the accidents that could involve these systems.

The accidents that would potentially result in a hazardous chemical release are a fire in the cation exchange drums, a fire in the activated carbon drums, and a spill of potassium hydroxide. These accidents would all occur inside the 243-5Z Building.

The accidents which would potentially result in a facility operations upset are those that involve a failure of the system to supply cooled water to the four heat exchangers supporting the two process air compressors and the air sampling vacuum pumps (Wash Hi Torqs). The PSAR for Projects B-68OH and C-040 (Kubinski 1992) addressed this subject in its PHA and concluded that the event would have no significant safety consequence.

It was concluded in the B-680H PSAR that postulated accidents associated with Projects B-680H and $\mathrm{C}-040$ would have no significant effects outside of the PFP immediate area. Operation of the facility would be an acceptable risk to the onsite worker, the general public, and the environment. Detailed evaluation of accident probabilities were not performed since the accidents were shown to have an "acceptable risk at annual probabilities no greater than one in one hundred."

To protect the environment, continuous DCS monitoring of 1iquid levels of holding and process tanks along with sump leak detection will be possible. This upgrade, combined with future additions of instruments and sensors, can provide the operator with early warning indications of an upcoming excursion prior to reaching an operational safety requirement (OSR) limit. A further advantage is the inherent ability of a DCS to accommodate new tasks and to add more automation to existing systems by simply adding the necessary $\mathrm{I} / 0$ devices and making some minor software configuration changes.

While the MICON" A/S system assumes the control and monitoring functions it does not impose upset conditions beyond those analyzed. The modifications made under this project will not introduce any new types of accidents and in all cases should enhance control and readout reliability. This would result in decreased risk due to a decrease in accident probability without any offsetting increase in consequences.

\subsubsection{Electrical Power System. In general, electrical power is not a} requirement for preventing onsite or offsite releases. Electrical upsets on the heating and ventilating system at PFP are discussed above. Loss of electrical power to any combination of fans could, at worst, result in an abnormal occurrence with slight contamination spread, as experienced infrequently, but would not cause onsite or offsite releases (WHC 1991). The response times to an electrical disturbance would be one to three minutes as the new control room will be cont inuously manned. Therefore, miner disturbances will be readily detected and corrected. 
In some process cases, loss of power is the safe configuration. This DCS will not impact the potential for electrical power disturbances or outages, but rather will improve operator response by providing accurate information on system status. Operational risk will remain unchanged.

Standby generator overspeed signals are provided in the control room to enhance prompt action to prevent generator damage. These readouts do not replace the overspeed trips.

9.3.4.6 Stean System. Steam is used for heating of the buildings and for powering the exhaust turbines in the 291-Z building. The effect of failure of bujlding heating was not addressed in the PFP FSAR. Hence the phenomenon is considered to be of no consequence.

These exhaust turbines (1abeled ET-8 and ET-9) are listed as Safety Class 3 . If steam is lost then an upset of the 234-5Z building ventilation system would result in a loss of building ventilation. The consequences of this type of upset are discussed in the PFP FSAR (WHC 1991), paragraph 9.1.8. The MICON" A/S systens adds a readout alarm on the steam system. The MICONm A/S system also adds a control for a solenoid on the steam turbine reset. Both of these devices enhance system reliability as the MICON' A/S system provides readout and control in a continuously manned location. Thus the MICON ${ }^{m}$ /S system does not adversely affect the Safety Class ratings for the steam system. Operational risk thus remains unchanged.

9.3.4.7 Water System. Water is used for the bearings of the steam turbines, ET-8 and ET-9 and for the building fire suppression system (sprinkler system). other uses, such as drinking fountains, are not applicable to this discussion.

The effect of a water supply upset on the bearings of the ventilation fans was not evaluated in the PFP FSAR. This phenomenon is considered to be of no significant consequence. The fire suppression system was addressed in the Plutonium Finishing Plant Final Safety Analysis Report. (9.2.2B). The study concluded that the "supervised wet pipe sprinkler system" was a "most important active feature" for controlling "ordinary combustible materials." However, good housekeeping was credited as being able to minimize the combustible materials loading. The study continued to state that a fire of the required magnitude to have a major effect was an incredible event.

The MICON" A/S system provides alarm readouts for most of the fire alarms within the PFP complex. These alarm readouts are thus provided in a cont inuously occupied console. This enhances response capability. Thus it can be concluded that the addition of the MICON A/S system will not diminish the current safety of the water supply system or increase risk to plant operations.

9.3.4.8 Dry Air, Instrument Air, and Process Air. Two dry air supply systems exist, one each for the 234-5Z gloveboxes and for the $2736-Z$ glovebox. The PFP FSAR (WHC 1991) did address the dry air systems but not individually.

The PFP FSAR addressed the dry air system in paragraph 9.0.2.4, subsection E-6. The FSAR had recognized the potential of the dry air system to pressure gloveboxes in which the dry air system was used to levels above 
the surrounding room. A pressurization would drive radioactive contamination from the gloveboxes to the room. The FSAR upon evaluation concluded that the amount of contamination that could reach the environs would be, "well below the minimum detection level.

The MICON" A/S system duplicates monitoring and control functions of the dry air system. The MICON $A / S$ system thus does not change the risk from the dry air system as MICON' A/S system does not add controls but merely duplicates controls to the dry air system.

9.3.4.9 Instrument Air System - Supply or Performance. There is a fairly extensive instrument air system supplying a pneumatic control system for 234-5Z and power for dampers in the 2736-Z complex. The PFP FSAR does not address the consequences resulting from system problems associated with upsets in instrument air supply of performance for either facility.

Consequences in the $234-5 Z$ building are mitigated by steam driven exhaust fans that are independent of the electrical control system. An upset or loss of instrument air would automatically trip the ventilation system to the steam driven exhaust fans in 291-Z. A similar system does not exist for the 2736-Z complex.

The MICON" A/S system provides added surveillance of system performance but will introduce no additional hazards. Thus no change in safety classification or a revision to the FSAR is required. The risk associated with plant operations is unchanged.

9.3.4.10 17-in. Vacuum (576 mbar) System - Supply or Performance. The 17-in. vacuum system is officially labeled the 17-in. vacuum system. The 17-in. vacuum ( 576 mbar) system drives the CAM devices by drawing room air through a filter that will trap airborne contamination. This radioactive contamination can then alarm a radiation detector. The consequences from loss of the 17-in. vacuum (576 mbar) system has been largely mitigated by the use of local vacuum pumps for each CAM device.

The MICON' A/S system adds an alarm for the 17-in. vacuum (576 mbar) failure, a switch alarm for 17-in. vacuum (576 mbar) problem, a pressure signal transmitter for 17-in. vacuum (576 mbar) and a vacuum switch annunciating the loss of vacuum (17-in. (576 mbar)). None of these influence the consequences from a loss of 17 -in. vacuum (576 mbar) system but only enhance the response capability to a loss of 17-in. vacuum (576 mbar) system.

The risk associated with plant operations is unchanged.

9.3.4.11 The 26-in. (880 mbar) Vacuum System - Supply or Performance. The 26-in. ( 880 mbar) vacuum system is used within the 234-5Z building for fluid transfers, sparging of solutions and some offgas collection services. The only safety-related function of the $26-i n$. (880 mbar) vacuum system is the liquid detection interlock system (see OSR requirements in PFP FSAR).

The MICON" A/S system takes over the control, monitoring, and alarm systems for the $26-$ in. (880 mbar) vacuum system. The imposition of the MICON A/S system will not degrade system performance or add to the 1 ist of possible upsets that would cause change in safety classification or a revision to the FSAR. 
The liquid detection interlock system, which is safety related, will remain independent of the MICON A/S. The risk associated with plant operations is unchanged.

9.3.4.12 Upsets in the CAM System - Performance. The CAM is used throughout processing areas and on stack discharges to track airborne radioactive contamination. Upon detection of levels above airborne radioactive contamination normal background, the units will alarm locally and in the office of the Health Physics Technicians. The MICON' A/S system taps the alarm signal from the following CAMs and adds these alarms to the console readouts:

\author{
232-Z STACK CAM A/F \\ 241-Z/296-ZB STK CAM \\ 241/296-Z CAM FAIL \\ 2736-Z ROOM CAM A/F \\ 2736-ZA CAM FAIL \\ 2736-ZB RM CAM A/F \\ 2736-ZB STACK CAM A \\ 2736-ZB STK CAM FAIL \\ 291-Z STACK CAM \\ 291-Z1 STK CAM FAIL \\ FILTER 9AB CAM FAIL \\ NDA AREA CAM ALARM 2736-ZB
}

The imposition of the MICON" A/S system will not degrade system performance or add to the list of posstble upsets that would cause a change in safety classification or a reviston to the FSAR. The MICON A/S system adds only redundant alarm functions to the console readouts. Thus, failure of the MICON $A / S$ system will not result in the loss of local annunciation. The risk associated with plant operations is unchanged.

\title{
9.4 RESULTS AND CONCLUSIONS
}

Review of existing safety systems and potential modifications to these systems have not revealed any unresolved safety issues. These systems can be interfaced to the MICONm A/S with no loss in system effectiveness.

Typically, these systems will retain their hardware interlock configuration as they currently exist.

The proposed upgrade is virtually a point-to-point replacement of an existing control system with a new digital control system. The upgrade does not require the replacement of HVAC equipment or equipment control schemes and, therefore, does not require a change in the HVAC flow sheets other than readout and control symbology. Thus, it is not credible that the proposed upgrade will impact the existing inventory or source terms resulting from the inventory under accident or upset conditions. 


\subsection{CONDUET OF OPERATIONS}

\subsection{PROCESS MONITORING AND CONTROL}

The MICON A/S will be configured to mimic the existing control strategy. Where there is now a hardwired controller or interlock, a controller or interlock will be configured into the new system. The only changes will be the identification number used. In some cases, these numbers will be changed to accommodate the new system. Therefore, the only changes to the current operating will remain the same. The only change seen by the operators will be that instead of using hardwired controls on a panel board, they will use a CRT/keyboard combination to make control changes.

Two OCSs and a supervising station will be provided by Project B-610. Each work station consists of a central processor, two CRT monitors, a keyboard, a mouse or trackball, and a four-pen strip-chart recorder. Each ocS will be configured to allow control monitoring and control of the entire HVAC Power Control Room. This control room oversees a variety of plant services consisting of ventilation, electrical power, steam, water, dry air, instrument air, process air, and several vacuum systems. This way, if one ocs should fail, operations can continue while the station is being repaired.

Using the keyboard and mouse/trackball, the operator can call up displays on either of the two CRTs and make control changes. Since the system has windowing capability, more than one display can be shown on a CRT. This gives the operator the ability to view a large portion of the plant configuration all at once. Process historical data (trends) are collected and stored on a hard disk by the central processor. This data can be displayed on the CRTs. The operator may also elect to display trend data on the strip chart recorder as we 11.

Certain operations, such as waste transfers, require approvals by the shift supervisor. Under the new MICON" A/S, these approvals will be accomplished using a SCS. The SCS is similar to the OCS except for the closed-circuit television. By password access, the supervisor will actuate supervisory interlocks using the SCS. The operation requiring supervisor's approval cannot proceed unless the appropriate supervisory interlock is activated. Without password access, the SCS will only allow HVAC monitoring and data collection. No control changes will be allowed. As a backup, supervisory interlocks will also be accessible through the ocss using password access.

An EWS will be provided to allow for configuration maintenance and changes. The EWS will be similar to the SCS and will be located in Building 270-Z. During normal operation, the EWS will be available for HVAC monitoring and data collection. No control actions will be allowed. Access to the configuration and other engineering functions will be by passord.

\subsection{TRAINING}

Three types of training class for the new system will be available; operator training, maintenance training, and engineering training. 


\subsubsection{Operator Training}

Operator Training will teach the process operators how to control and monitor the HVAC system and other PFP parameters using the MICON" A/S. Familiarity with the OCSs, displays, and functions will be included in the course. The operator training course will be taught in addition to the normal process operator training. The course will also be useful to anyone requiring access to the MICON' A/S for data collection.

\subsubsection{Maintenance Training}

Maintenance training will be provided to troubleshoot and repair MICON A/S hardware. In addition, general system operation will be taught. This course will be designed to train the instrument technicians in how to maintain and repair the MICON A/S hardware.

\subsubsection{Engineering Training}

Engineering training includes training in system operation and maintenance in addition to training on how to set up and configure the system. Only those engineers and technicians requiring direct access to the system configuration will take this course.

\subsection{HVAC FLON DIAGRAMS}

Project B-610 will affect the HVAC flow diagrams. These drawings will be kept current using ECNs.

\subsection{SPARE PARTS}

All components of the MICON $A / S$ shall be standard products of the manufacturer. Operations will finalize, at a later date, a list of MICON" A/S parts or components to be stored on hand for immediate use in the event of a component failure.

\subsection{SOFTMARE CONFIGURATION CONTROL}

Configuration control analysis and change control shall be in accordance with the configuration management plan (DeSant is 1994).

\subsection{OPERATIONAL SAFETY REQUIRENENTS}

There will be no changes to any operational safety requirements as a result of Project $B-610$. 


\subsection{QUALITY ASSURAHCE}

\subsection{QUALITY ASSURANCE PROJECt PLAN}

The Project 8-610 specific quality assurance program plan (QAPP) establishes quality requirements for design, procurement, and construction for the complete project. Refer to document WHC-SD-610-QAPP-001, Rev. 1, for the specific QAPP (Riste 1992).

\subsection{PROCESS engtneERING WORK PLAN}

The manufacturer's standard software will be programmed into the MICON' $A / S$ before delivery by the manufacturer. The MICON A/S will only need to be "configured" to the required application. PFP Process Engineering will design and input the specific configuration; test, document and manage this configuration. Configuration acceptance testing and PRF operational testing will be in accordance with WHC-CM-6-1, EP-4.2, "Testing Practices." The configuration requirements for the MICON $A / S$ will be in accordance with the updated pipe and instrumentation diagrams (P\&IDs).

\subsection{TECHNICAL ISSUES REQUIRING FURTHER EVALUATION}

- Compatibility between the MICON' A/S and all field devices shall be verified.

- A detailed analysis on any Safety Class 1 and 2 systems that interface with the MICON A/S shall be performed prior to the end of definitive design and this analysis shall be included in the project FSAR.

- A detailed anaiysis shall be performed on the MICON A/S binary logic diagrams prior to the end of definitive design and this analys is shall be included in the project FSAR. 
. 


\subsection{REFERENCES}

Acree, C. D., 1990, Specification for Process Monitoring and Control System, Project B-610, WHC-S-042, Rev. 2, West inghouse Hanford Company, Richland, Washington.

DeSantis, G. N., 1994, Computer Software Configuration Nanagement Plan for Plutonium Finishing Plant MICON" "Open Automation System," WHC-SD-SP-CSCM-008, Westinghouse Hanford Company, Richland, Washington.

DOE, 1989, General Design Criteria, DOE Order 6430.1A, U.S. Department of Energy, Washington, D.C.

DOE-RL, 1989, Standard Architectural-Civil Design Criteria: Design Loads for Facilities, SDC-4.1, Rev 12, U.S. Department of Energy, Richland Field office, Richland, Washington.

Kubinski, K. J., 1992, Preliminary Safety Analysis Report for Project 90L-EWB680H and Project 91G-GEC-040, WHC-SD-CP-PSAR-005, Rev. 5, West inghouse Hanford Company, Richland, Washington.

Nearing, R. R., 1989, Conceptual Design Report: Plutonium Reclamation Facility, Process Instrumentation Upgrade, Project B-610, WHC-SD-610-CDR-001, Rev. 0, Westinghouse Hanford Company, Rich1and, Washington.

NFPA-13, (91), Installation of Sprinkler Systems, Published by the National Fire Protection Association.

NFPA-70, (90), National Electrical Code, Published by the National Fire Protection Association.

Nester, D. E., 1993, PFP Safety Systems and Equipment List, WHC-SD-CP-TI-108, Rev. 13, Westinghouse Hanford Company, Richland, Washington.

Riste, M. E., 1992, Plutonium Finishing Plant Instrument Upgrade, Project B-610, WHC-SD-610-QAPP-001, Rev. 1, Westinghouse Hanford Company, Richl and, Washington.

Silvan, G. R., 1994, B-610 PFP Instrumentation Upgrade (PFP HVAC Control Room Upgrade), WHC-SD-610-TI-001, Westinghouse Hanford Company, Richland, Washington.

WHC, 1991, Plutonium Finishing Plant Final Safety Analysis Report, WHC-SD-CP-SAR-021, Rev. 0, Westinghouse Hanford Company, Richland, Washington.

WHC, 1991, Management Requirements and Procedures, WHC-CM-1-3, West inghouse Hanford Company, Richland, Washington.

WHC, 1993, WHC Radiological Control Manual, WHC-CM-1-6, Westinghouse Hanford Company, Richland, Washington. 
WHC, 1993, Nonreactor Facility Safety Analysis Manua7, WHC-CM-4-46, West inghouse Hanford Company, Richland, Washington.

WHC, 1991, Standard Engineering Practice, WHC-CM-6-1, Westinghouse Hanford Company, Richland, Washington.

Wilk, J. L., 1992, 291-Z Process Air Compressors, WHC-SD-C-171-CR-001, Rev. 2, Westinghouse Hanford Company, Richland, Washington.

Wilk, J. L., 1994, PFP Instrument Upgrade Functional Design Criteria, WHC-SD-610-FDC-001, Rev. 5, Westinghouse Hanford Company, Richland, Washington. 
WHC-SD-610-PSAR-002 REV 1

APPENDIX A

A-1 
WHC-SD-610-PSAR-002 REV 1

This page intentionally left blank.

A-2 


\section{PROJECT B-610 INSTRUNENT DATABASE}

\section{G. R. Silivan}

373-2943

The database being used for Project B-610 (234-5 Instrument Upgrade) is attached. The database contains all the instruments and related equipment that will be connected to the new MICON' A/S control system being installed under this project. As project needs change, this database will be changed by supplement to the most current safety documentation. Please contact the author for the most recent database updates. The database was written for use in dBaseIII. Copies of the database may al so be obtained from the author.

\section{Explanation of Fields}

P\&ID: The existing instrumentation drawing on which the instrument should appear.

New P\&ID: The new instrumentation drawing on which the instrument will appear. This drawing will be created by the project.

Device: The instrument's ID.

Type: The type of device (eg: TRANS = Transmitter).

Function: The instrument's function or description.

Range: The input/output range required by the instrument.

Status: A special status identifier.

NOD (Not on Drawing) Does not appear on the listed P\&ID.

NIO (No I/0) Will not be connected to the control system.

NEW New equipment -- to be purchased by the project.

HWR Part of an independent hardware interlock or safety system. It usually will not be connected to the control system.

WSH Wish list item. The status of this item may change depending on project needs.

Safety

class: $\quad$ The Safety Class of the instrument as determined from WHC-SD-CP-TI-108. (Nester 1993)

Building \&

Location: The building and location from where the instrument will be tied into the control system. NOTE: These fields may not reflect the actual equipment location.

Groupings: Used as special sorting fields to aid in system configuration.

Alarms: Any alarms or interlocks associated with the instrument.

I/0 Count: Used to count the number of inputs and outputs to the system. 
$A I=$ Analog Input; $A O=$ Analog Output;

DI = Discrete Input; and DO = Discrete Output.

Termination: Used to identify the termination points on the system for the instrument. Up to four points can be identified (A, B, C, \& D). The format for the termination point is:

Cabinet- Rack - Slot - Point

MICON' \&

Location:

The MICON" number and location of the RCM-32 controller that the instrument will be wired to.

Comments: Any comments about the instrument. 
Old_pid: 26009-15 Now_pid: Dovnum: ET-1-25A Dovtyo: TRANS VOLT Dovtun: FAN CONTA FNL VOLTS Dovloc: RM 321A PANEL F Intrange: 4-20 MA Status: NEW Safoty: 3 Loop: EI_FAN Loophun:
Commonts:

Tomb: bo:

Terme: Torma: 321 UR1_N Voesel: HVAC

Alarms: $\quad$ Micon: RM321_1_4 Micon_no: 33 Bdo: $234-52$

Ai: 1 Ao: 0 Di: 0 Do: 0 Leuloc: RM 321A

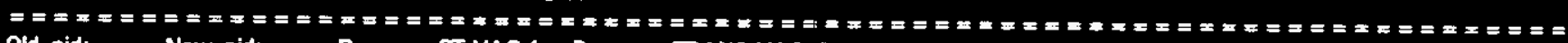
Old_pid: Now_pid: Dovnum: PT-VAC-1 Dovtypa: TRANS VAC Dovfun: 17" VACUUM Intrange: 4-20 MA Status: NEW Safoty: 3 Loop: Comments:

Termb: Alann: Ai: 1 Ao: 0 Di: 0 Do: Oleuloc: Loopbun: Veusel: ITVAC

Dovioc: AM 321A PANEL G ABOV

O Levoc: AM 321 A

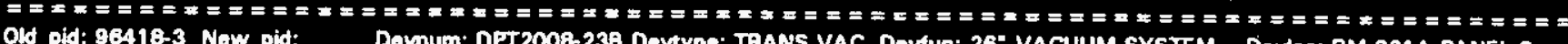
Intrango: 10-50 MA Stintus: Dowum: DPT2008-238 Dovtype: TRAMS VAC Dovin: 26" VACUUM SYSTEM Devoc: RM 321A PANEL $G$ Safoty: 4 Loop: P $1128 \quad$ Loopbun:
Voscol: 26VAC

$\begin{array}{llll}\text { Tomb: lob: Tormc: } & \text { Tormd: } & \text { lod: } \\ \text { Alarms: } & & \text { Micon: RM321_1_6 Mieon_no: } 35 \text { Bldg: } 234-52\end{array}$

$\begin{array}{llll}\text { Tomb: lob: Tormc: } \quad \text { Tormd: } & \text { lod: } \\ \text { Alarms: } & & \text { Micon: RM321_1_6 Mieon_no: } 35 \text { Bldg: } 234-52\end{array}$ SUPPL

Ai: 1 Ao: 0 Di: 0 Do: 0 Leubo: AM 321A

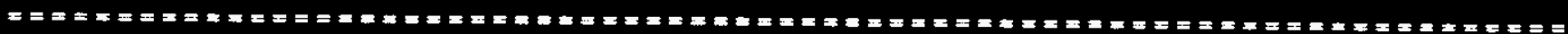
Old_pid: 26009-9 Now_pld: Dovnum: TT-10-25A Dovtypo: TRANS TEMP Dovfun: 2N 3 (DUCT S-2) TEMP Dovloc: RM 321A Intranse: 4-20 MA Stotus: NEW Safoty: 3 Loop: TH-10 Loopbun: Voenol: HVAC Comments: (WAS TT-10 REPLACES T1-10-25A (PANEL G) Torma: 321_UA1_IV_3 loa: A1_TT10 $\begin{array}{llll}\text { Tormb: lob: } \quad \text { Tormc: } & \text { Tormd: Micon: RM321_1_4 Micon_no: } 33 \text { Bido: } 234-52\end{array}$

Ai: I Ao: O Di: O Do: 0 Leuloc: AM 321A

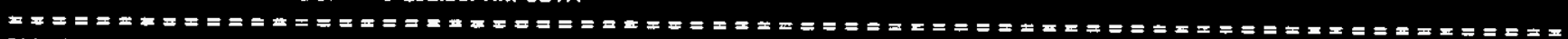
Old_pid: 26089-9 Now_pid: Dovnum: TT-11-25A Dovtype: TRANS TEMP Dovfun: ZN 3(DUCT S-3) TEMP Dovloc: RM 321A Intrenge: 4-20 MA Stotus: NEW Sofoty: 3 Loop: TI-11 Loopbun: Veseol: HVAC Commont: (WAS TT-11 -- TT-13 BEFOAE) - REPLACES T1-11-25A (PANEL 0 Toma: 321 UR1_V_3 loa: AI_TT11 Tormb: lob: Tormc: loc: Micon: AM321_1_5 Mican_no: 34 Eldo: 23452 Ai: 1 Ao: O Di: O Do: 0 Leuloc: RM 321A

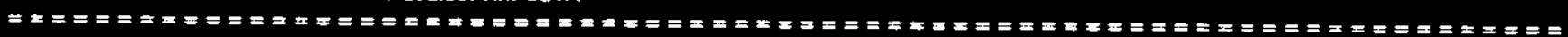
Old_pid: 26089-9 Now_pid: Dovnum: TT-12-25A Devtypo: MANS TEMP Doviun: ZN 3A(DUCT S-3ATTEMP Dovloc: RM 321A Intrange: 4-20 MA Status: NEW Safoty: 3 Loop: TH-12 Loopbun: Voseal: HVAC
C Comment: (WAS TT-12) REPLACES TI-12-25A (PANEL I) Torme: 321_UA1_VI_3 los: Al_TT12
Tormb: $\quad$ lob: Termb: lob: Tormc: loc: Micon: RM321_1_6 Micon_no: 35 Bldg: 234-52

Ai: 1 Ao: O Di: 0 Do: 0 Leuloc: RM 321A

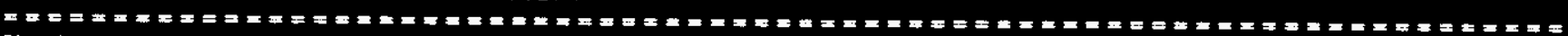
Old_pid: 260a9-9 Now_pid: Dovnum: TT-9-25A Dovtypa: TRANS TEMP Dovfun: ZN 1(DUCT S-1) TEMP Dovloc: RM 321A Intrande: 4-20 MA Status: NEW Safoty: 4 Loop: TR9 Comments: (WAS TT-9) REPLACES T1-9-25A (PANEL G) Termb: lob: Torme: loc: Loopbur: Tormd: Vessel: HVAC

Alarms: $\quad$ Micon: RM321_t_6 Micon_no: 35 Bddd: $234-52$ Ai: 1 Ao: 0 Dl: 0 Do: 0 Leuloc: RM 321A

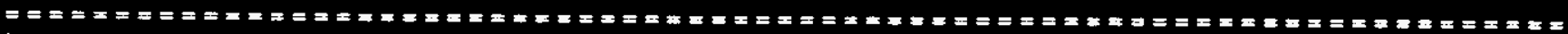
Old_pid: 46804-1 Now_pid: Dovnum: TC1E Dovtypo: TRANS TEMP Dovfun: STAGE 1 REACTOR TEMP Devioc: RM 321 A PANEL M Intrange: Status: NEW Safaty: 3 Loop: T1_TC1E Loopbun: Vescel: AlR-E Comments: PT-C PROBE NOD - SEE H-2-96436-4 Toma: 321 UA1_IV_11 loa: Al_TC1E $\begin{array}{llll}\text { Tomb: lob: Terme: } & \text { Tornd: Micon: RM321_1_4 Micon_no: 33 Eldo: 234-52 }\end{array}$ Ai: 1 Ao: 0 Di: O Do: 0 Lculoc: AM 321A

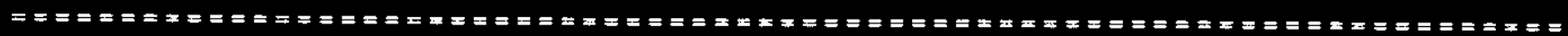
Old_pid: 46804-1 Now_pid: Dovnum: TC1s Dovtypo: TRANS TEMP Doviun: REACTOR STAGE 1 TEMP Dovbo: RM 321 A PANEL M Intrange: Statur: NEW Safoty: 3 Loop: TI_TC1S Loopbun: Veesel: AIR-S Commonts: PT-C PROBE SEE H-2-96422 Terma: 321 UA1_V_11 loa: Al_TC1S Tormb: lob: Terme: loc: Tormd: lod: Alarms: $\quad$ Micon: AM321_1_5 Micon_no: 34 Bldo: 234-52 Ai: 1 Ao: 0 Di: 0 Do: 0 Lculoc: RM $321 \mathrm{~A}$

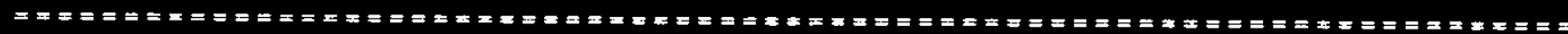
Old_pid: 46884-1 Now_pid: Dovnum: TC2E Dovtype: TAANS TEMP Dovtun: STAGE 2 REACTOR TEMP Dovoc: RM 321 PANEL M intrange: Status: NEW Safoty: 3 Loop: TI_TC2E Loopbun: Vecrel: AIR-E Comments: PT-C PROBE NOO - SEE H-2-96436-4 Torma: 321_UA1_IV_12 loa: A1_TC2E Tormb: lob: Termc: loc: Termd: lod: Alarm: $\quad$ Micon: RM321_1_4 Micon_no: 33 Bldg: 234-52 Ai: 1 Ao: O Di: O Do: O Leuloc: AM 321A

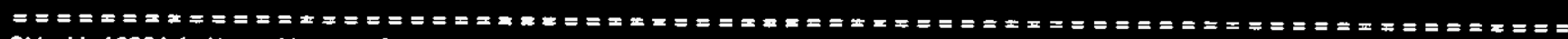
Old_pid: 46884-1 Now_pid: Dovnum: TC2S Dovtype: TRANS TEMP Dovfun: REACTOR STAGE 2 TEMP Dovloc: RM 321 A PANEL M $\begin{array}{llll}\text { Intrange: Status: NEW Sofoty: } 3 \text { Loop: T1_TC2S } & \text { Loopbun: } & \text { Vosesel: AlR-S } \\ \text { Commente: PT-C PROBE SEE H-2-96422 } & \text { Tormai 321 UA1 V 12 loa: AI_TC2S }\end{array}$

Torma: 321 UA1_V_12 loa: AI_TC2S 


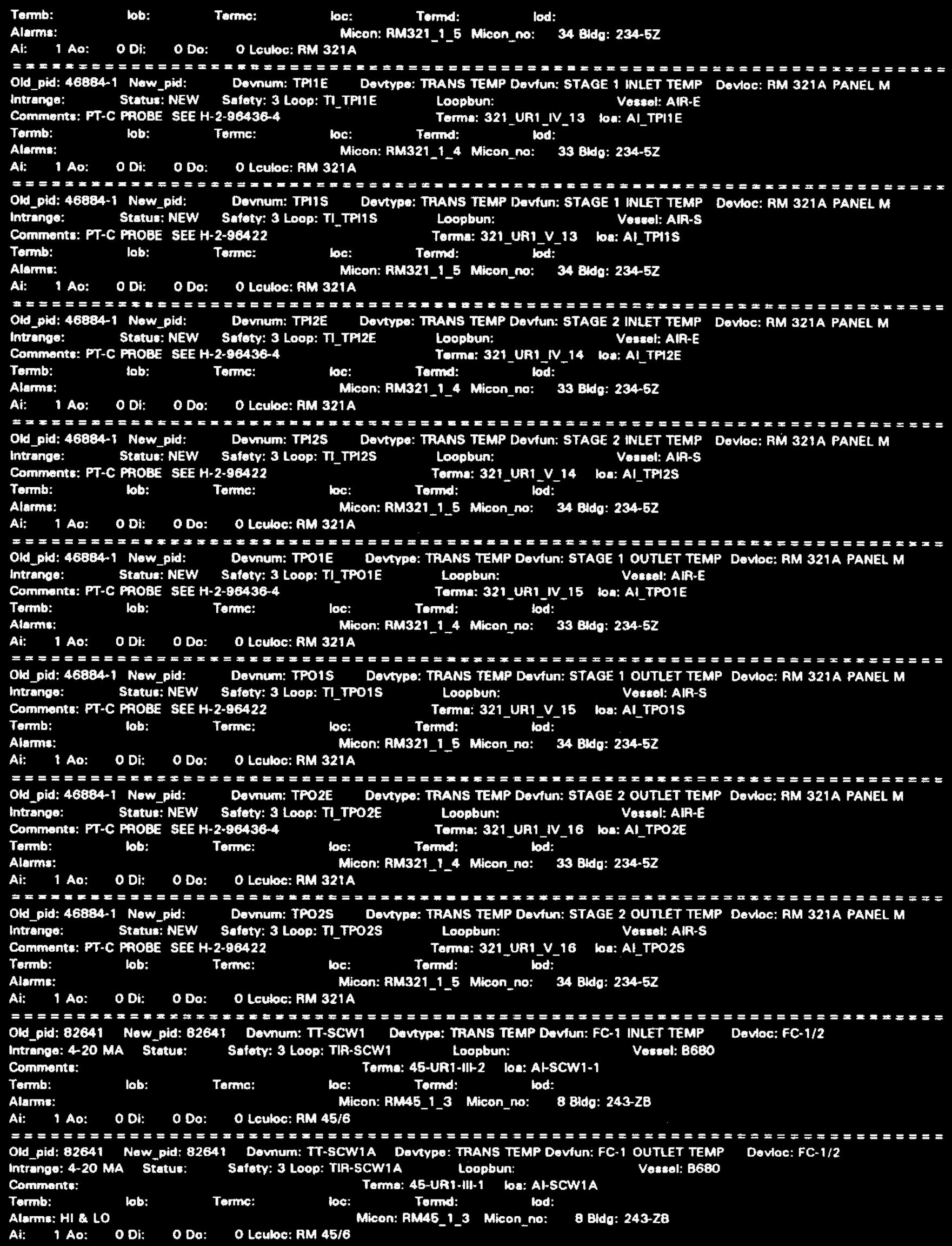




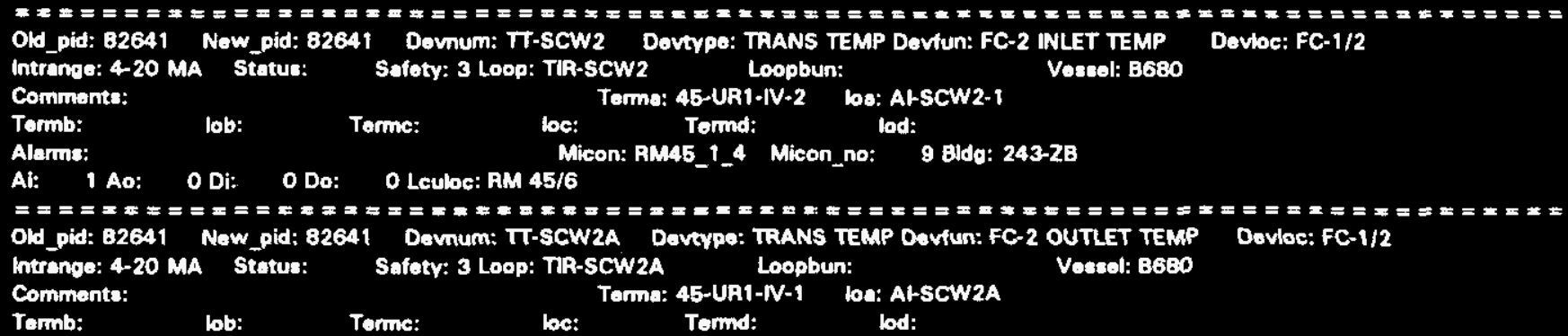

Alams: HI LO Micon: RM45_1_4 Micon_no: 9 Bdo: $243-28$

Aj: 1 Ao: 0 Di: 0 Do: 0 Lculac: RM $45 / 6$

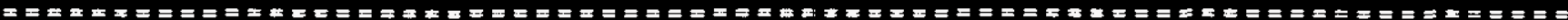
Old_pid: 82642-1 Now_pid: 82642-1 Dovmum: TT-PCW1 Dovtypo: TRANS TEMP Deviun: GB LOOP TEMPERATURE Dovloc: RM 35 Intrenge: 4-20 MA Status: Safety; 3 Loop: nh-PCW1 Vescel: B680

Commonts: $\quad$ Torma: 45-UA1-IV-11 bo: Al-PCW1-3

Tormb: lob: Tormc: loc: Tormd:

Alarms: LO Micon: AMA5_1_4 Micon_no: 9 Bldg: $236-2$

Ai: I Ao: O Di: 0 Do: 0 Leuloc: AM $45 / 6$

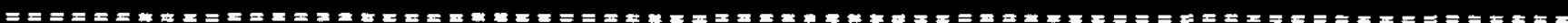
Old_pid: B2642-2 New_pid: 82642-2 Dovnum: TT-PCW5 Dovype: TRANS TEMP Doviun: VP-1 LOOP TEMP. Dovoc: RM 35

Intrang: 4-20 MA Stetus: Safoty: 3 Loop: TIR-PCW5 Loopbun: Vessol: 8680

Comments: $\quad$ Torma: 45-UR1-lil-4 ba: A-PCW5-1

Tormb: - lob: Tormc: loc: Tornd:

Alarms: HI Micon: RM45_1_3 Micon_no: 8 Bldo: 236-Z

Ai: 1 Ao: O Di: O Do: 0 Leuloc: RM $45 / 6$

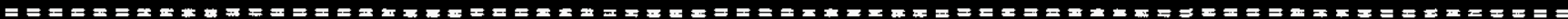
Old_pid: 82642-2 Now_pid: 82642-2 Dovnum: TT.PCW6 Dovtypa: TRANS TEMP Devtun: VP-2 LOOP TEMP.

Intrang: 4-20 MA Status: Safoty: 3 Loop: TIR-PCW6 Loopbun: Vosed: BeGO

Commente: $\quad$ Torma: 45-UP1-NV-4 bo: AtPCW6-1

Termb: lob: Tarme: loc: Temd: lod:

Alarms: HI Micon: RM45_1_4 Micon_no: 8 Bldo: 236-Z

Ai: 1 Ao: $O$ Di: $O$ Do: $O$ Leuloc: AM $45 / 8$

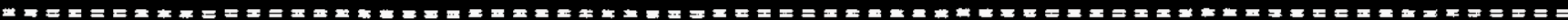
Old_pid: Now_pid: Dovnum: Dovtype: TRANS FRES Doviun: 90: AlR PREsSURE Dovioc: RM 321A PANEL G ABOV

Intrang: 4-20 MA Stotus: NEW Safoty: 4 Loop: Loopbun: Voecol: AlP

Commenta: $\quad$ Tema: 321_UA1_V1_14 lon:

Termb: lob: Terme: loc: Tarmd: - lod:

Alarns: $\quad$ Micon: RM321_1_8 Micon_no: 35 Bldo: 23452

Al: 1 Ao: 0 Di: 0 Do: 0 Lculoc: AM 321A

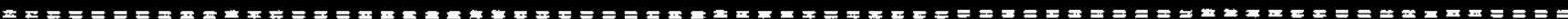

Old_pid: Now_pid: Dovnum: Dovypo: TRANS PRES Doviun: INSTR AIR PRESSURE Dovioc: RM 321A PANEL H ABOV

Intrange: 4-20 MA Status: NEW Safoty: 3 Loop: Loopbun: Vectel: AlA

Commente: NOT LABLED Toma: 321 UA1_VI_13 lo:

Termb: lob: Torme: loc: Termd:

Alarms: LO Micon: AM321_1_6 Micon_no: 35 Bldg: 234-52

Ai: 1 Ao: 0 Di: 0 Do: 0 Leuloc: RM $321 \mathrm{~A}$

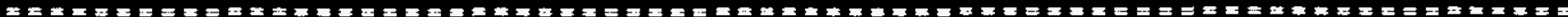
Old_pid: 26089-10 Now_pid: Dovnum: PT-5-25A Dovtypo: TRANS PRES Dovfun: zONE 30 STATIC PREsS Dovoc: RM 321 A PANEL I Intrande: 4-20 MA Stotus: NEW Safoty: 3 Loop: P15 Loopbun: Voseal: HVAC

Comments: (WAS PT-5-1) AEPLACES PIR-5-25A loc: Torma: 321_URt_IV_4 loa: Al_PT5
Tormb:

$\begin{array}{lll}\text { Tormb: } \quad \text { lob: } \quad \text { Terme: } & \text { Tormd: } & \text { lod: } \\ \text { Alarms: } & & \text { Micon: RM321_1_4 Micen_no: 33 Bldg: } 234-52\end{array}$

Ai: 1 AQ: 0 Di: 0 Do: 0 louloc: AM $321 \mathrm{~A}$

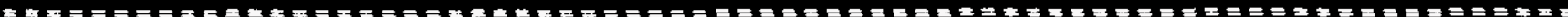
Old_pid: 26089-9 Now_pid: Dovnum: PT-2-25A Dovtypa: TRANS Fres Devfun: ZONE 1 STATIC PRESS Devloc: RM 321A PANEL G Intrange: 4-20 MA Status: NEW Safoty: 4 Loop: PF-1 Loopbun: Vossol: HVAC

Commante: (WAS PT-1-1) REPLACES PAR-1-25A

Termb: lob: Terms: loc: Tarnd:

Alarme: $\quad$ Micon: RM321_1_6 Micon_no: 35 Bidg: 234-52

Ai: 1 Ao: 0 Di: $O$ Do: 0 Lculoc: RM 321A

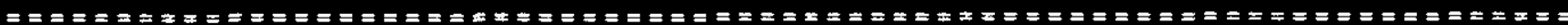
Old_pid: 26069-8 Now_pid: Devnum: PT-3-25A Devtye: ThANS PRES Devfun: ZONE 3 STATIC PAESS Dovoc: RM 321A PANEL 6 Intrange: 4-20 MA Status: NEW Safoty: 3 Loop: Pl-3

Comments: (WAS PT-2-1) REPLACES PIR-3-25A

Temb: lob: Tormc: loc:

Termd:

Alarme: $\quad$ Micon: RM321_1_4 Mican_no: 33 Bddg: 234-52

Ai: 1 Ao: 0 Di: O Do: O Leuloc: AM 321A

z Old pid: 26089-8 New_pid: Domum: PT-4-25A Dovtype: TRANS FRES Dovin: ZONE 3A STATIC PRESS Devloc: AM 321A PANEL I 
Intranoe: 4-20 MA Status: NEW Safoty: 3 Loop: P-4 Comments: (WAS PT-4-1) REPLACES PAR-4-25A

Tormb: lob: Termo: loc:

Loopbun:
Torma: 321 UA1_V_2 lost: AI_PT4
Tormd:
M321_1_5 Micon_no: 34 Bidd: $234-52$

Micon: AM321_1_5 Micon..no: 34 Bdd: $234-52$

Ai: 1 Ao: 0 Di: O Do: 0 Lculoc: AM $321 \mathrm{~A}$

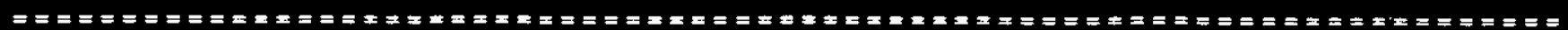
Old_pid: 80167.6 Now_pid: Dovnum: PE-4 Intronge: 4-20 MA Status:

Commonte:

Tamb: Safoty: 3 Loop: POIC 3

Devtypo: TRANS faEs Dovfun: ZN II MNL FRESSURE Dovoc: RM 60212302

Alarms: 10

Ai: 1 Ao:

bl:

Terme:

Loopbun:

Vescel: 28

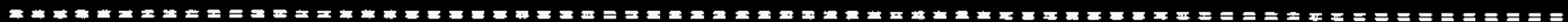
Old_pid: 82642-1 Now_pid: 82642-1 Domum: PT+PCW1 Dovype: TRANS FaEs Dovin: GB LOOP PRESSURE Devoc: AM 35 Intrenge: 4-20 MA Stetus: Safoty: 3 Loop: PIA-PCW1 Loopbun: Commonte:

Tormb: Terma: 45-UR1-IV-12 ba: AHPCW1-4

Alarms: Lo Micon: fMA5_1_4 Micon_no: 8 Bdd: 236-Z

Ai: 1 Ao: 0 Di: 0 Do: 0 Leuloc: RM 45/6

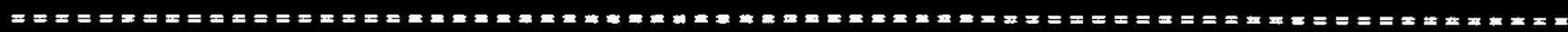
Old_pid: 82642-2 Now_pid: 82642-2 Domum: PT-PCW5 Dovtype: TRANS FaES Devfun: VP-1 LOOP PAESSUAE Davloc: RM 35 Intrang: 4-20 MA Status: Safoty; 3 Loop: PIA-PCW5 Loopbun: Commente:

Tormb:

lob:

Torme: Tema: 45-UR1-IIL5 loa: AFPCW5-2

Alarms: Lo $\quad$ Micon: RM45_1_3 Micon_no: 8 Bldg: 236-Z

Ai: 1 Ao: 0 Di: 0 Do: 0 Leuloc: RM 45/s

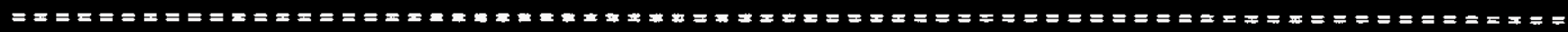
Old_pid: 02642-2 Now_pid: 02642-2 Devnum: PT-PCW6 Dovtype: TRANS PRES Dovfun: VP-2 LOOP FRESSURE Dovloc: RM 35 Intrenge: 4-20 MA Status: Safoty: 3 Loop: PiR-PCW6 Loopbun: Commonts:

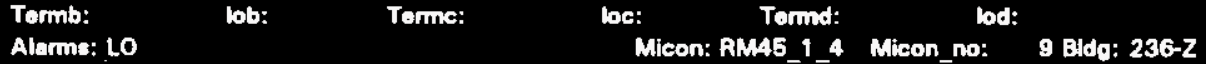
lob:

Tormb: lob: Terme: loc: Micon: AM45_1_4 Micon_no: 9 Bldg: 236-Z
Alarms: LO Torma: 45-UAt-IV-5 loa: AP-PCW6-2

Ai: 1 Ao: 0 Di: 0 Do: 0 Lculoc: AM $45 / 6$

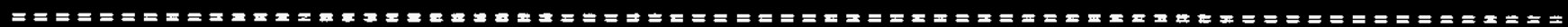
Old_pid: 82733 Now_pid: 82733 Downum: PT.2 Intrange: 4-20 MA Status: Safoty: 3 Loop: PMR-2 Dovtype: TAANS FREs Dovfun: TRAN INLET PRESSURE Dovloc: $243-2$ Commente:

Tomb: lob: Termc: Loopbun: Vesecel: 8690 Alarms: HI $\quad$ Micon: WTF_1.4 Micon_no: 3 Blda: 243-Z

Ai: 1 AO: O Dt: O Do: OLeuloc: $243-2$

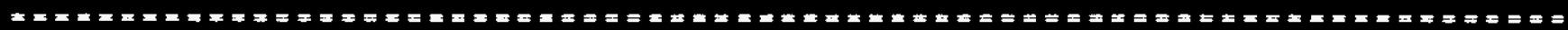
Old_pid: 82747 Now_pid: 82747 Devnum: PT-4 Intrango: 4-20 MA Status: Safoty: 3 Loop: Pl-4 Commente:

Tormb: Terme:

Doutypo: TRANS PAES Dovtun: $243-2$ BULLING PAES Dovoc: $243-Z$

Mleon: WTF_1 4 Micon_no: 3 Bldg: $243-2$

Ai: 1 Ao: 0 Di: O Da: 0 Lculoc: $243-2$

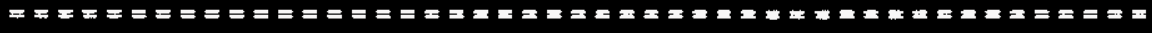

Old_pid: 82732 Now_pid: 82732 Devnum: AIT-1 Dovtype: TRANS PH Devfun: INLET FH Intrango: 4-20 MA Status: Safety: 3 Loop: AlC-201 $\quad$ Loopbun: AlC-201
Commente:

$\begin{array}{ll}\text { Commente: } & \text { Torma: 243-UA1-ill-4 los: AR-8 } \\ \text { Tormb: lob: Torme: } & \text { Tornd: }\end{array}$

Alarms: $\quad$ Micon: WTF_1_3 Micon_no: 2 8ldg: 243-Z

Ai: 1 Ao: O Di: O Do: OLculoc: $243-Z$

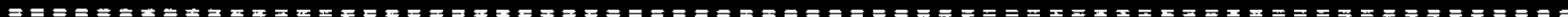
Old_pid: 82733 Now_pid: 82733 Devmum: AlT-3 Dovtypo: TRANS PH Davtun: OUTLET PH

Intrano: 4-20 MA status: Safoty: 3 Loop: At-3 Loopbun: Veseol:

Commonte: $\quad$ Tamma: 243-URt-Ill-6 lon: At-10

Tormb: lab: Torme: loc: Termd: lod:

Alarms: HI Micon: WTF_1_3 Micon_no: 2 Bldg: 243-Z

Ai: 1 Ao: 0 Di: 0 Do: 0 Leuloc: 243-2

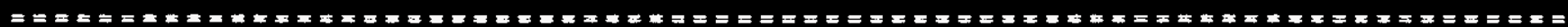
Old_pid: 96418-5 Now_pid: Dovnum: PHT-1 Dovypo: TRANS PH Dovfun: SILENCER TANK PH Devoc: AM 321A 26VAC Intrange: 4-20 MA Status: Safoty: 4 Loop: Al_TST Loopbun:

Commente:

Termb:

Devloc: $243-2$

Alarms: HI, LO Micon: RM321_1_4 Micon_no: 33 Bldg: 23452

Ai: 1 Ao: O Di: O Do: 0 Leuloc: AM 321A

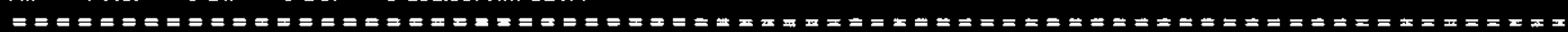
Old pid: 82732 New_pid: 82732 Dovnum: LT-1 Dovtype: TAANS LVL Dovfun: T-101 SUMP LEVEL Dovloc: $243-2 A$

Intrange: 4-20 MA Status: Sofoty: 3 Lo0p: LIC-101

Comments:

Tomb:

lob:

Torme:

Torma: 243-UA1-III-1 loa: Alt

Vessel: 8680

Devloc: $243-Z$ 


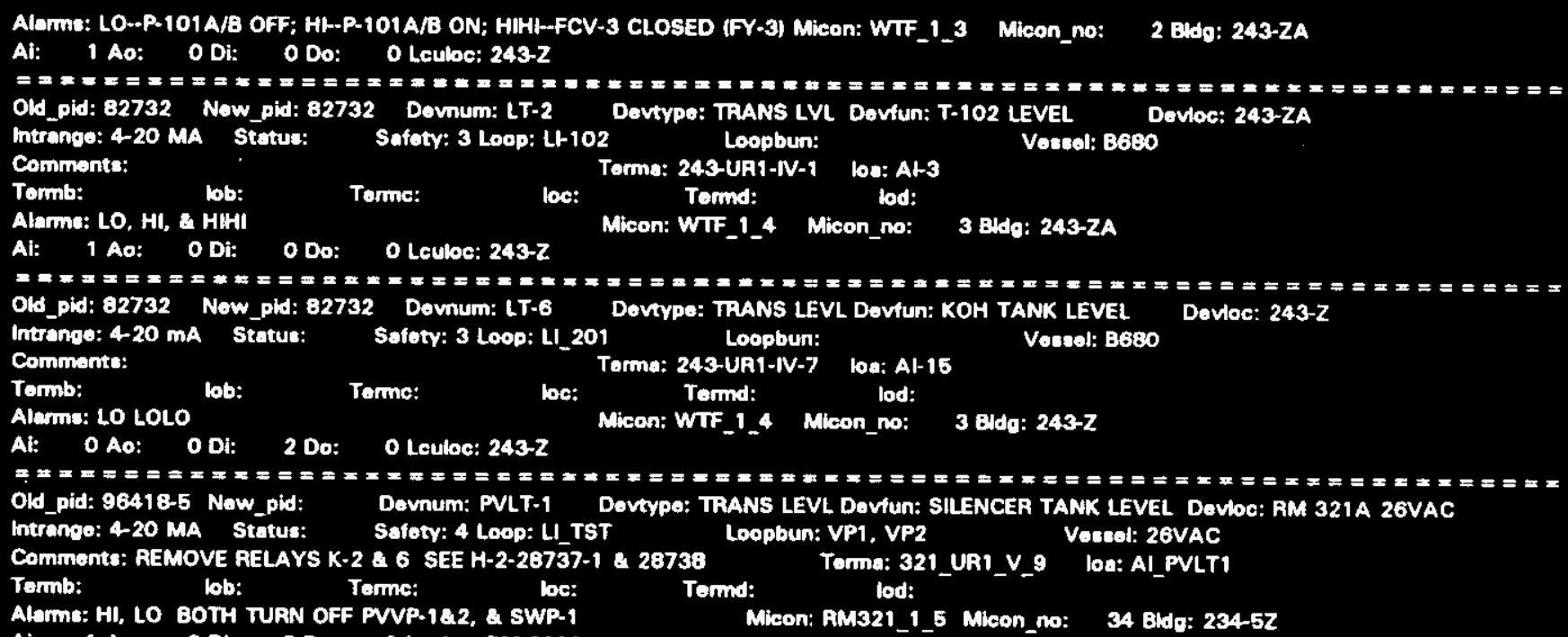

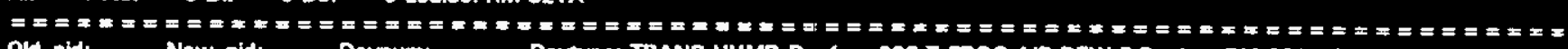
Old_pld: Now_pid: Downum: Dovtypo: TRANS HUMD Davtun: 236-Z PAOC AIR DEW P Dovloc: RM 321A PANEL G Intranoe: 4-20 MA Status: Safoty: 4 Loop: Loopbun: Vossel: AlR

Commants: $\quad$ Toma: 321 UA1_VI_12 los:

Termb: lob: Torme: loc: Termd:

Alarms: $\quad$ Micon: AM321_1_6 Micon_no: 35 Bdo: $234-52$

Ai: 1 Ao: 0 Di: 0 Do: 0 Lculoc: RM 321A

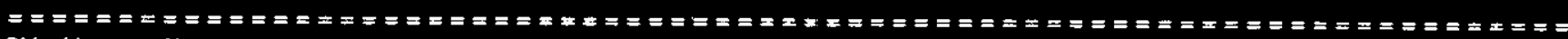

Old_pid: Now_pid: Devnum: 1A-OWPPWCR1 Dovtypo: TRANS HUMD Devtun: 291-Z INST AIR DEW P Devloc: RM 321 A PANEL $G$

Intrange: 4-20 MA Status: Safoty: 3 Loop: Loopbun: Vessel: AlR

Comments: $\quad$ Toma: 321 UR1_VI_15 loa:

Tormb: lob: Terme: loc: Tormd: lod:

Alarms: $\quad$ Micon: PM321_1_6 Micon_no: 35 Bidg: $234-62$

Ai: 1 Ao: 0 Di: 0 Do: 0 Lculoc: RM 321A

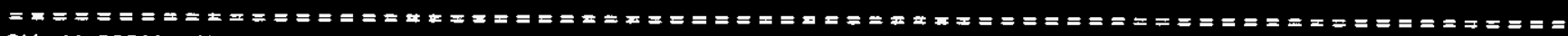
Old_pid: 82641 Now_pid: 82641 Dovnum: FY-SCW1 Devtpe: TRANS FLOW Dovfun: FC-1 OUTLET FLOW Devloc: FC-1/2 Intrange: 4-20 MA Status: Safoty: 3 Loop: FIR-SCW1 Loopbun: Vosel: B680

Comments:

Temb: lob: Tormc: loc: Tornd: lod:

Alarme: $\quad$ Micon: RMA5_1_3 Micon_no: 8 8lde: 243-2B

Ai: 1 Ao: 0 Di: 0 Do: 0 Lculoc: AM 45/6

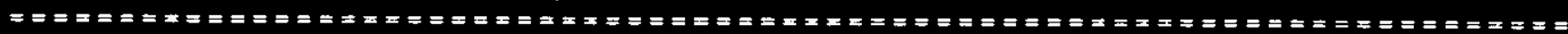
Old_pid: 82641 Now_pid: 82641 Dovnum: FY-sCW/2 Dovtype: TRANS FLOW Davfun: FC-2 OUTLET FLOW Dovioc: FC-1/2 Intrange: 4-20 MA Status: Safoty: 3 Loop: FIA-SCW2 Loopbun: Veseal: B680 Commants:

Termb: bo:

Terma: Torma: 45-UA1-IV-3 lod:

Alarms: $\quad$ Micon: RM45_1_4 Micon_no: 9 Bidg: 243-28

Ai: 1 Ao: 0 Di: 0 Do: 0 Lculoc: RM 45/6

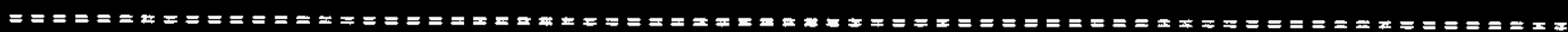
Old_pid: 82642-1 Now_pid: 82642-1 Dovnum: FT.PCW1 Dovtype: TRANS FLOW Davfun: GB LOOP FLOW Intrangs: 4-20 MA Status: Safoty: 3 Loop; FIR-PCW1 Loopbun: Vossel: Beso Devloc: RM 35 Commonts:

Termb: lob: Terme: loc: lo Tarmd:

Tormb: lob: Terme: loc: 10 Tormd: Torma: 45-UA1-IV-10 loa: Al-PCW1-2

Ai: 1 Ao: 0 Di: O Do: 0 Lculoc: AM $45 / 6$

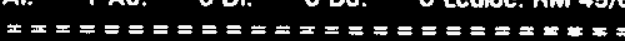

Old_pid: 82642-2 Now_pid: 82642-2 Devmum: FT-FCW5 Dovtypo: TRANS FLOW Dovfun: VP-1 LOOP FLOW Safoty: 3 Loop: FIR-PCW5

Devtypo: TRANS F
Loopbun: $\begin{array}{cc}\text { Toc: } & \begin{array}{c}\text { T5-UAt-Ill-7 loa: Al-PCW5-4 } \\ \text { Tormd: }\end{array}\end{array}$

Commonts:

Termb:

lob:

Terme:

Micon: RM45_1_3 Micon_no:

B Bldo: 236-Z

Ai: 1 Ao: 0 Di: 0 Do: 0 Lculoc: AM $45 / 6$

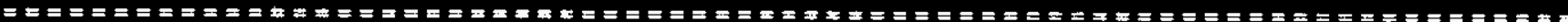
Old_pid: 82642-2 Now_pid: 82642-2 Devmum: FT-PCW6 Devype: TRANS FLOW Devfun: VP-2 LOOP FLOW Intrande: 4-20 MA Status: Safoty: 3 Loop: FIR-PCW6 Loopbun:

Commants:

Tormb: Torma: 45-UA1-10-7

Veseat: Bego

Devloc: AM 35

Davloc: RM 35

Alarma: LO Micon: AM45_1_4 Micon_no: 9 Bldo: 236-Z

Ai: 1 Ao: 0 Di: 0 Do: O Leuloc: RM $45 / 6$

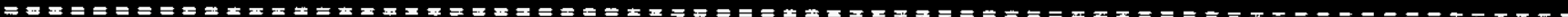




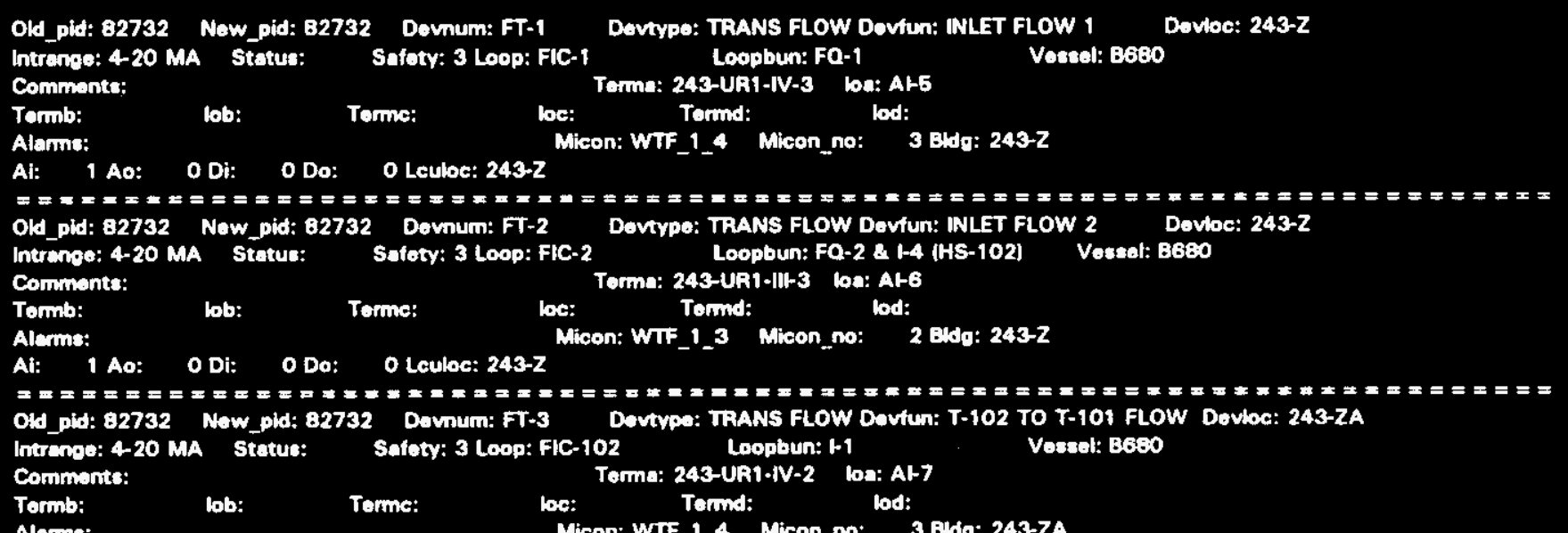

Alarms: $\quad$ Micon: WTF_1_4 Micon_no: 3 Bidg: 243-ZA

Ai: 1 Ao: 0 Di: 0 Do: 0 Lculoc: $243-2$

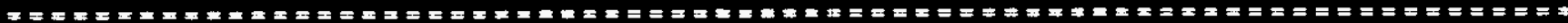
Old_pid: 26089-11 Now_pid: Dovnum: PDT-168 Dovtype: TRANS DP Doviun: AM 169 TO ATM DP Dovloc: AM 321 A WEST WALL Intrange: 4-20 MA Stotus: NEW Safoty; 4 Loop: PDI_166 Loopbun: Veasel: HVAC

Commants: REPLACE EXITING DPI Terma: 321_UP1_V_4 Ioa: AI_166

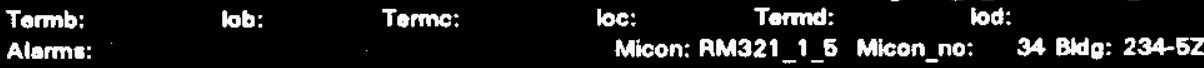

Ai: I Ao: O Di: O Do: O Leuloc: AM 321A

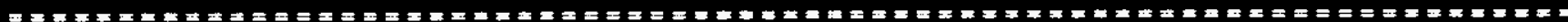
Old_pid: 26009-11 Now_pid: Downum: PDT-227 Dovtype: TRANS DP Dovfun: AM 227 TO ATM DP Devloc: RM 321A WEST WALL Intronge: 4-20 MA Status: NEW Safoty: 4 Loop: PDI_277 Loopbun:

Commants: $\quad$ Terma: 321_UA1_VI_4 bo: Al_227

Termb: lob: Torme: loc: Toind:

Alame: $\quad$ Micon: RM321_1_e Micon_no: 35 Bldo: $234-52$

Ai: 1 Ao: 0 Di: 0 Do: 0 Lculoc: RM 321A

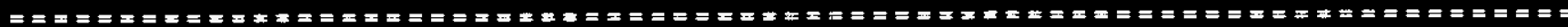
Old_pid: 26088-11 New_pid: Dovnum: PDT-228A Devtype: TRANS DP Devfun: RM $228 A$ TO ATM DP Dovoc: RM 321A WEST WALL

Intrange: 4-20 MA Status: NEW Satoty: 4 Loop: PDI_228A Loopbun:
Commente:

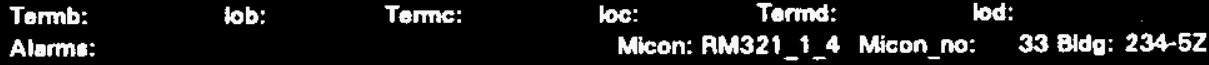

Ai: 1 Ao: 0 Di: 0 Do: 0 Leuloc: AM 321A

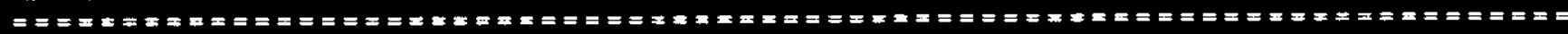
Old pid: 26089-11 Now_pid: Devnum: PDT-2288 Devtye: TRANS DP Devfun: RM 2288 TO ATM DP Devloc: RM 321 A WEST WALL Intrenge: 4-20 MA Status: NEW Safoty: 4 Loop: FDI_2288 Loopbun: Vocsed: HVAC Commonts:

Termb: bo: Tarme: loc: Torind: - lod:

Alems: $\quad$ Micon: RM321_1_5 Micon_no: 34 Blda: $234-52$

Ai: 1 Ao: 0 Di: 0 Do: 0 Leuloc: AM 321A

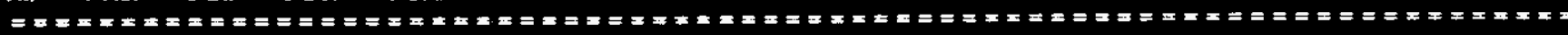

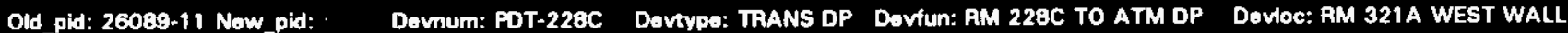
Intrange: 4-20 MA Status: NEW Safoty: 4 Loop: FDI_228C Loopbun: Comments:

Termb: lob: $\quad$ Torme: $\quad$ loc: $\quad$ Tormd:
Alarms:

Ai: 1 Ao: O Di: O Do: 0 Lculoc: RM $321 \mathrm{~A}$

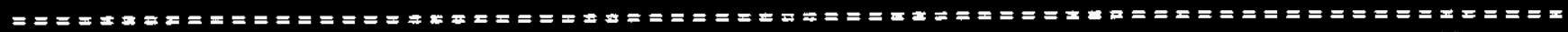
Old_pid: 26089-11 Now_pid: Dovnum: PDT-230A Dovtype: TRANS DP Doviun: AM 230A TO ATM DP Dovloc: RM 321A WEST WALL Intrange: 4-20 MA Status: NEW Safoty: 4 Loop: PDI_230A Loopbun:

Comments: $\quad$ Terma: 321 UA1_IV_6 ba: AI_230A

Tormb: bb: Tome: loc: Micon: AM321 14 Micon_no: 33 81ds: 234-52

Ai: 1 Ao: 0 Di: 0 Do: 0 Lculoc: RM 321A

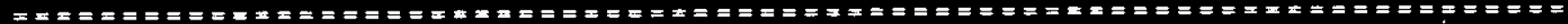
Old_pid: 26009-11 Now_pid: Davnum: POT-2303 Davtypo: TRANS DP Dovfun: AM 2303 TO ATM DP Dovloc: RM 321 A WEST WALL Intrango: 4-20 MA Status: NEW Safoty: 4 Loop: POI_230B Loopbun: Vessel: HVAC

Comments: $\quad$ Terma: 321 UR1_V_6 loa: Al_230B

Tomb: lob: Torme: loc: Tornd:

Alarms: $\quad$ Micon: AM321_1_5 Micon_no: 34 Blda: 234-52

Ai: 1 Ao: O Di: O Do: O Leuloc: AM $321 \mathrm{~A}$

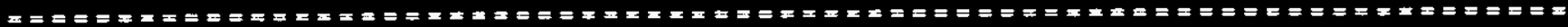
Old_pid: 26089-11 Now_pid: Dovnum: FDT-230C Dovtype: TAANS DP Dovtun: RM 230C TO ATM DP Devloc: RM 321A WEST WALL Intranos: 4-20 MA Status: NEW Sofoty: 4 Loop: PDI_230C Loopbun: Vossal: HVAC

Commente:

Torma: 321 UR1_VI_6 lon: Al_230C 


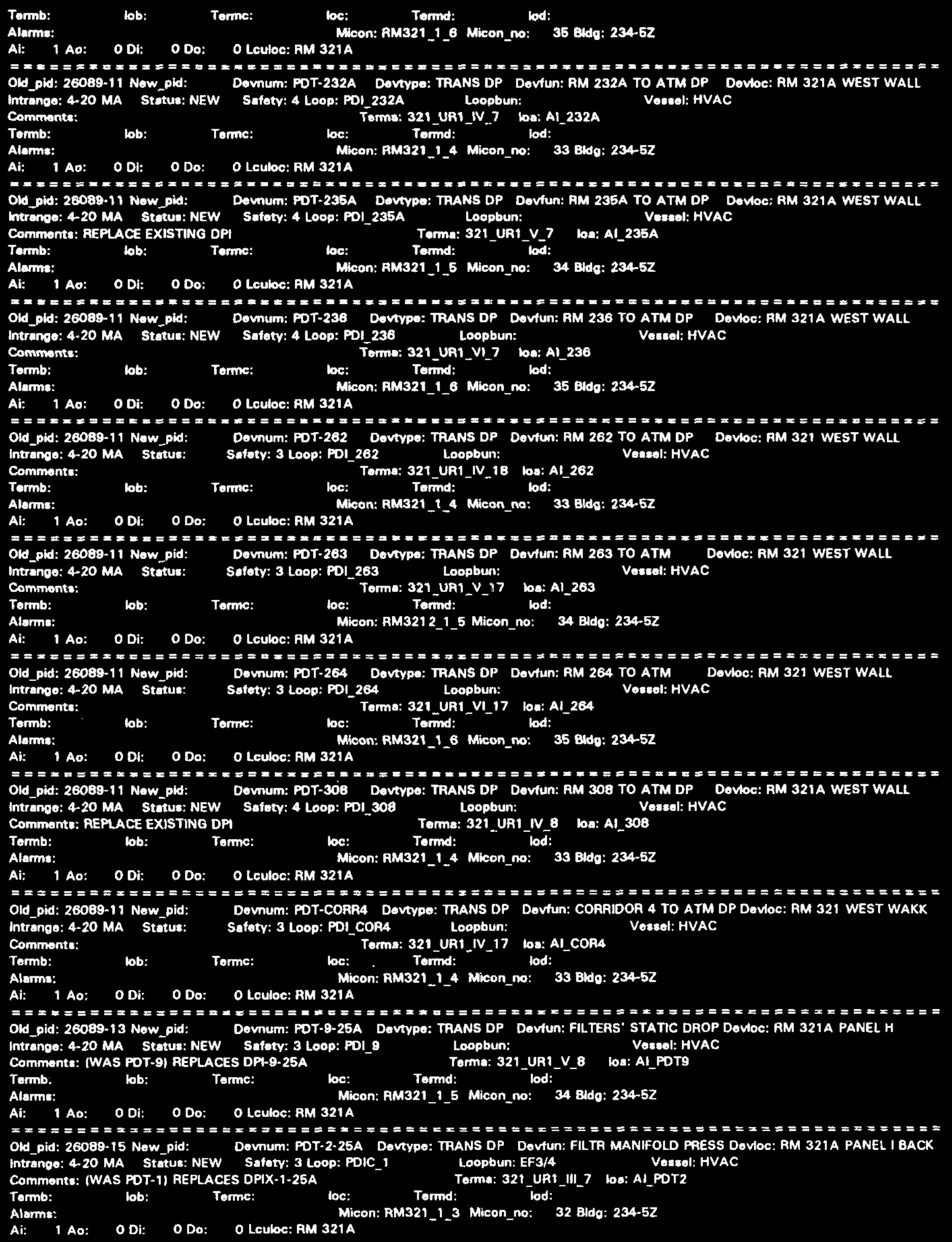




\section{WHC-SD-610-PSAR-002 REV 1}

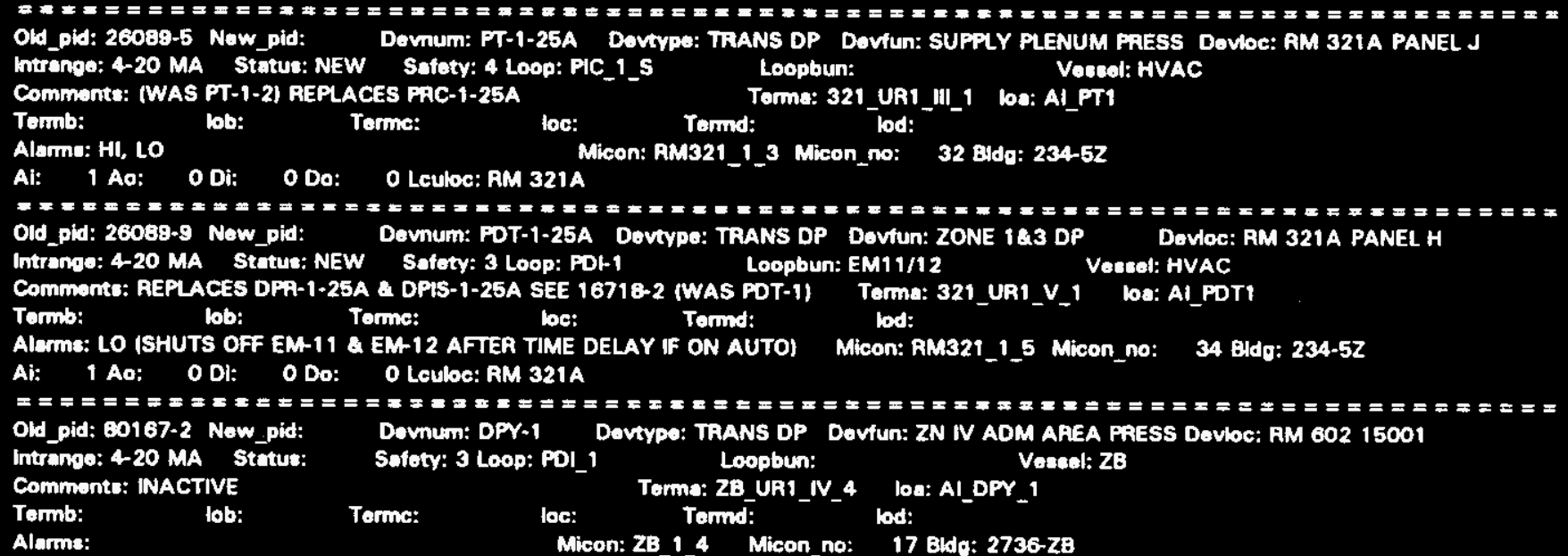

Ai: 1 Ao: O Di: O Do: O Lculoc: RM 602

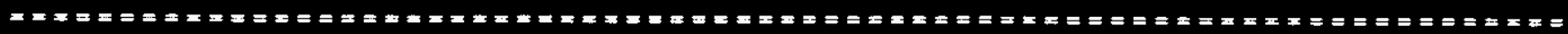
Old_pid: 80167-2 Naw_pid: Dovnum: PE-1 Dovtypo: TRANS OP Doviun: ZN IV ADM AREA PRESS Dovloc: AM 60212300

Intrance: 4-20 MA Status: Sofoty: 3 Loop: PolC-1
Commente:

Tormb: lob: Torme: loc: Tormd: ${ }^{-}$lod:

Alarmo: LO Micon: ZB_1_3 Micon_no: 16 Bldg: 2736-ZB

Ai: 1 Aa: O Di: O Do: 0 Leuloc: RM 602

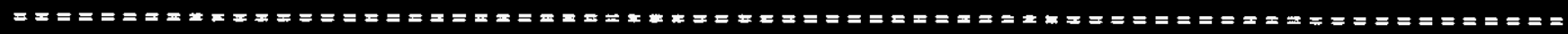
Old_pid: 80167-3 Now_pid: Dovnum: DPY-2 Dovtypo: TRANS DP Doviun: 2N II FRCS AREA FRES Devtoc: RM 602 15002

$\begin{array}{llll}\text { Intrange: 4-20 MA Status: Safoty: } 3 \text { Loop: PDI_2A } & \text { Loopbun: } & \text { Voesel: ZB } \\ \text { Comments: INACTIVE } & & \text { Torma: ZB UA1_IV 7 loa: Al DPY } 2\end{array}$

Tomb: lob: $\quad$ Torme: loc: Tarmo:

Alarms: $\quad$ Micon: Z8_1_4 Micon_no: 17 Bida: $2736-2 B$

Ai: 1 Ao: 0 Di: 0 Do: 0 Lculoc: RM 602

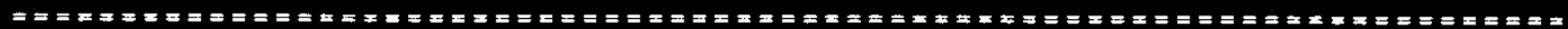
Old_pid: 80167-3 Now_pid: Devnum: DPY-4 Dovtrpe: TRANS DP Dovtun: ZN 1 GBX PRESS Devloc: RM 602 15004

Intrande: 4-20 MA Status: Safoty: 3 Loop: PDI_4A Loopbun: Vessel: ZB

Torma: ZB_UR1_IV_8 loa: Al_DPY_4

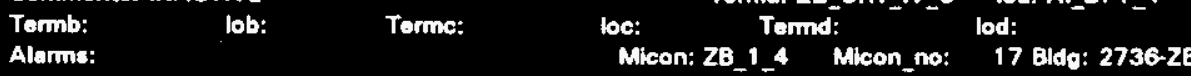

Ai: 1 Ao: 0 Di: 0 Do: 0 Lculoc: RM 602

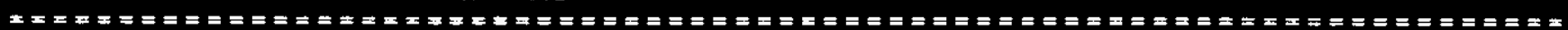
Old_pid: 80167-3 Now_pid: Downum: PE-2 Dovtypo: TRANS DP Dovtun: ZN II PRCS AREA PRES Devloc: RM 602 12301

Intrang: 4-20 MA Status: Safoty: 3 Loop: PDIC_2 Loopbun:

Commente: $\quad$ Toma: Z8_UP1_ill_2 loa: AI_PE_2

Tormb: lob: Torme: loc: Terind: ${ }^{-2}$ lod:

Alarms: $10 \quad$ Micon: ZB_t_3 Micon_no: 16 Bldo: $2736-28$

Ai: 1 Ao: O Di: 0 Do: 0 Leuloc: AM 602

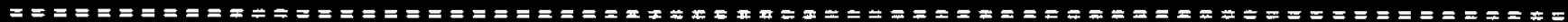
Old_pid: 80167-3 Now_pid: Dovnum: PE-5 Dovtypo: TRANS DP Dovtun: ZN 1 GBX PAESS Davloc: AM 602 12303

Intrange: 4-20 MA Status: Safoty: 3 Loop: PDIC_4 Loopbun:

Comments: $\quad$ Toma: ZB_UA1_III_3 loa: Al_PE_5

Alarms: Lo lob: Tormc: loc: ${ }^{2}$ Temd: 16 Bida: $2736-28$

Ai: 1 Ao: 0 Di: 0 Do: 0 Lcubc: AM 602

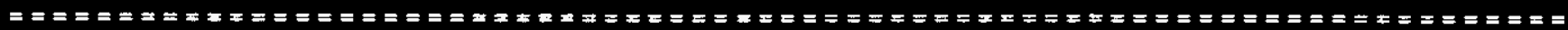
Old_pid: 80167-4 Now_pid: Devnum: DPY-1A Devtype: TRANS DP Devtun: INSTRUMENT AIR Devloc: RM 602 15000

Intrange: 4-20 MA Stotus: Safoty: 3 Loop: P1_1A Loopbun: Vosal: ZB

Commonte: $\quad$ Terma: ZB_UA1_IV_13 ba: Al_DPY1A

Tormb: lob: Tormc: be:

Alarms: LO Micon: ZB_1_4 Micon_no: 17 Bldg: $2736-28$

Ai: $1 \mathrm{Ao:} \quad 0 \mathrm{Di}$ 0 Do: 0 Leuloc: RM 602

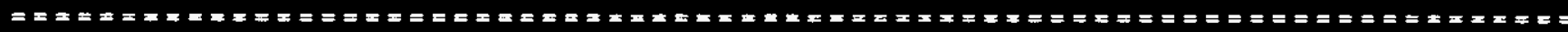
Old_pid: 80167-4 Now_pid: Dovnum: DPY-5 Dovtypo: TRANS DP Dovfun: EXHAUST PLENUM PAESS Dovloc: RM 602 15005

Intrangs: 4-20 MA Status: Safoty: 3 Loop: PDi 5A Loopbun: Vescel: ZB

Commante: INACTIVE $\quad$ Terma: ZB_UA1_IV_14 loa: AI_DPY_5

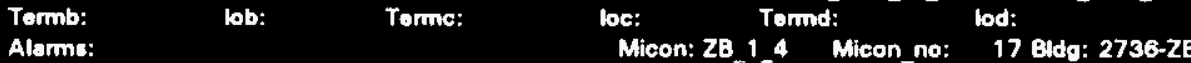

Ai: 1 Ao: 0 Di: 0 Do: 0 Leuloc: AM 602

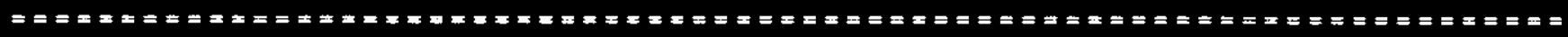
Old_pid: 80167-4 Now_pid: Dovnum: PE-3 Dovtypo: TRANS DP Doviun: EXHAUST PLENUM PRESS Devloc: RM 602 12304

Intrange: 4-20 MA Status: Safoty: 3 Loop: PDIC_5 Loopbun: Vossal: ZB 


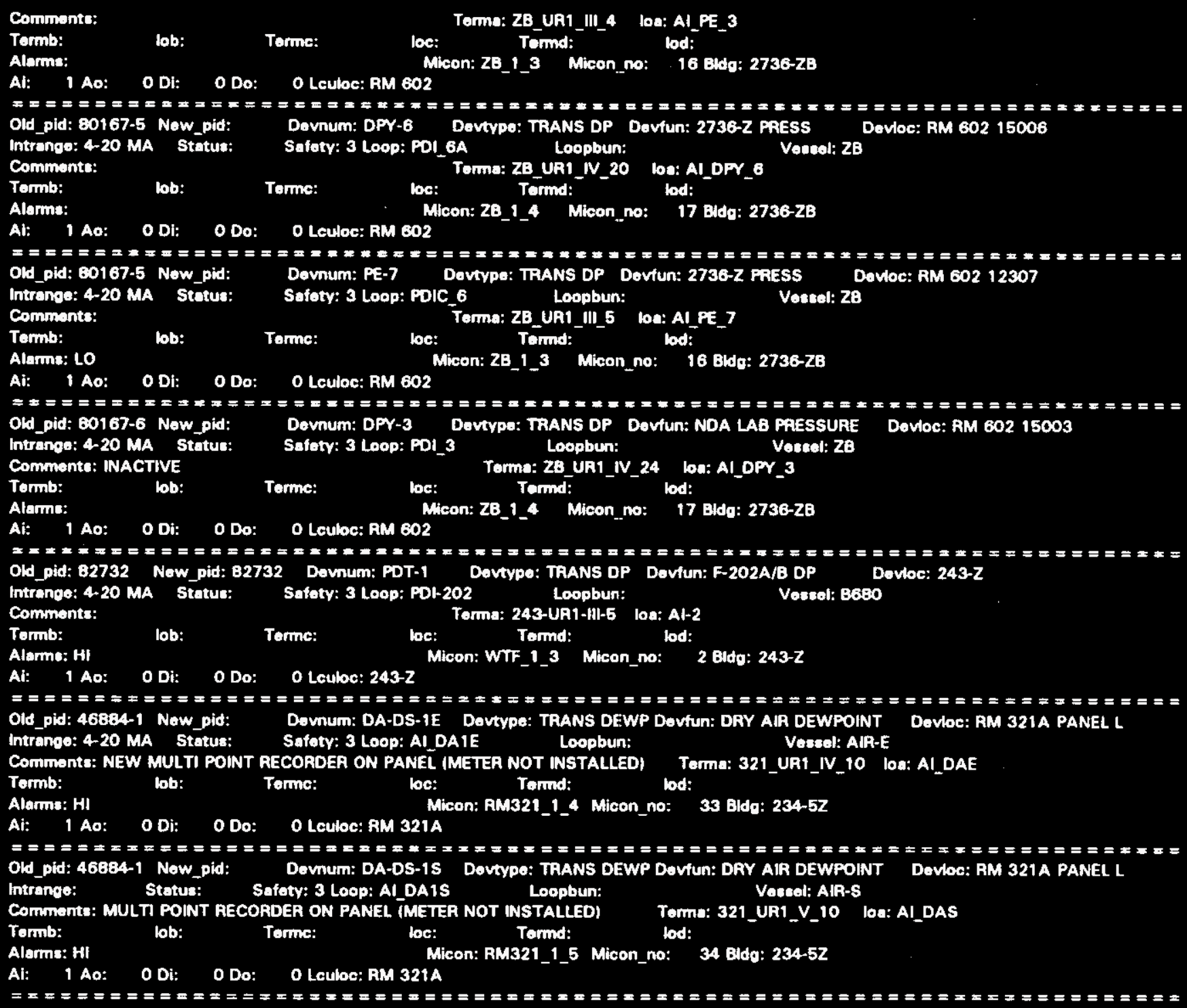


Old_pid: 46884-2 Now_pid; 46884-3 Downum:

Dovtype: TRANS DEWP Devfun: DRY AIR DEW PONT Intrange: 4-20 MA Status: NOD Safory: 3 Loop: Al DA Davioc: AM 321A PANEL L Commonts: NEW MULTI POINT REC ON PANEL (XMITTER NOT INSTALLED) Torma: 321_UR1_VI_10 loa: AI_DAT
Tomb: $\quad$ lob: $\quad$ Torme: $\quad$ loc:

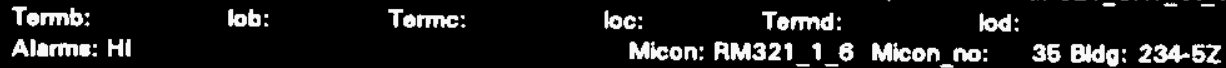

Ai: 1 Aa: O Di: O Do: 0 Leuloc: AM 321A

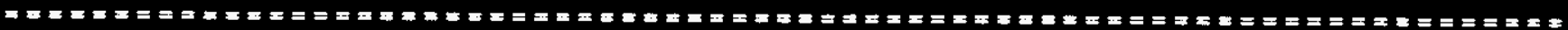
Old_pid: 82641 Now_pid: 82641 Downum: CT-SCW1 Davtypo: TRANS COND Dovfun: COOL LOOP CONDUCTIV. Dovioc: FC-1/2

Intrange: 4-20 MA Status: Satoty: 3 Loop: CiR-SCW1 Loopbun:

Terma: 45-UA1-N-8 lon: Al-SCW1-3

Tormb: lob: Torme: loc: Tormd:

Aloms: HI Micon: RM45_1_4 Micon_no: 9 Bido: $243-28$

Ai: 1 Aa: O Di: 0 Do: 0 Lcube: RM $45 / 6$

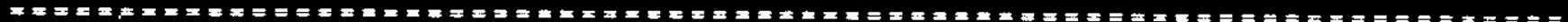
Old_pid: 82642-1 Now_pid: 82642-1 Davmum: CT-PCW1 Dovtypo: ThANS COND Deviun: GB LOOP CONDUCTIVIT Devloc: RM 35 Intrange: 4-20 MA Status: Safoty: 3 Loop: CIR-PCW1 Loophun:

Terma: 45-UA1-1V-9 ba: A-PCW1-1

Tomb: lob: Terne: loc: Tornd: lod:

Alarms: HI Micon: RM45_1_4 Mieon_no: 9 Bldd: 236-Z

Al: 1 Ao: O Di: O Do: O Leuloc: AM 45/8

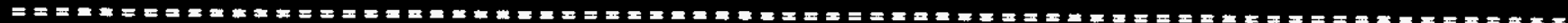
Old_pid: 82642-2 Now_pid: 82642-2 Davnum: CT-PCW5 Davtyo: TRANS COND Daviun: VP-1 LOOP CONDUCTIV. Devloc: RM 35 Intrande: 4.20 MA Stotus: Safoty: 3 Loop: CIR-PCW5 Loopbun:

Commente: $\quad$ Toma: 45-UA1-ill-8 ba: ARPCW5-3

Termb: bb: Torme: lac: Tormd: lod:

Alams: HI Micon: RM45_1_3 Micon_no: 8 Bidg: 236-Z

Ai: 1 Ao: 0 Di: 0 Do: 0 Lculoc: RM $45 / 6$

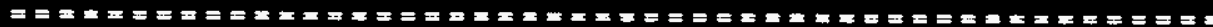
Old_pid: 82642-2 Now_pid: 02642-2 Dovnum: CT-PCW6 Davtypo: TRANS COND Devfun: VP-2 LOOP CONDUCTIV. Dovoc: AM 35

Intrange: 4-20 MA Statua: Safoty: 3 Loop: CIR-PCW6 Lapbun:

Commonts: $\quad$ Terma: 45-UA1-IV-6 los: ARPCWG-3

Tomb: lob: Terme: loc: Tormd: lod:

Alorme: HI $\quad$ Micon: RM45_t_4 Micon_no: 9 Bldg: 236-Z

Ai: 1 Ao: 0 Di: 0 Do: 0 Leuloc: RM $45 / 8$

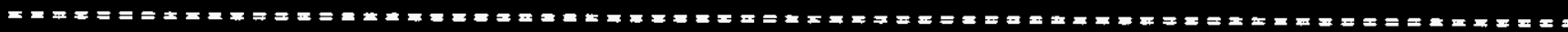
Old_pid: 82732 Now_pid: 82732 Dovnum: AIT-4 Dovtype: TRANS COND Dovfun: INLET CONDUCTIVITY Dovloc: 243-Z

Intrange: 4-20 MA Status: Satoty: 3 Loop: At-201 Loopbun: Voceal: B680

Comments:

Tormb: lob: Torme: loc: Temd: lod:

Alarms: HI Micon: WTF_1_3 Micon_no: 2 Bldo: 243-Z

Al: 1 Ao: O Di: O Do: OLculoc: 243-Z

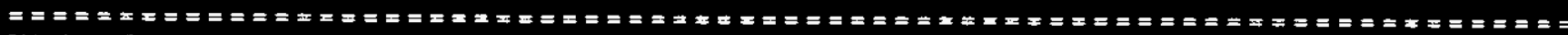
Old_pid: 82733 Naw_pid: 82733 Downum: AlT-2 Dovtype: ThANS COND Dovfun: OUTLET CONDUCTIVITY Devloc: $243-2$

Intrango: 4-20 MA Stotus: Safety: 3 Loop: Al-TR-2 Loopbun:

Comment:

Termb:

lob:

Termc:

3-UAT-IV-5

Vessel: B680

Ai: 1 Ao: 0 Di: 0 Do: 0 Leuloc: 243-7

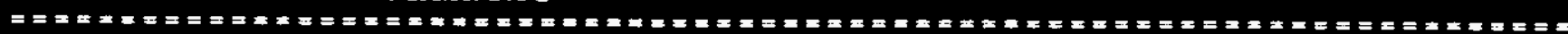
Old_pid: 80167-2 Now_pid: Devnum: AMP-COND-1 Dovtype: TAANS AMP Dovin: CONDENSER 1 AMPS Dovloc: AM 602 12000 Intrange: 4-20 MA Stutur: NOD Commente:

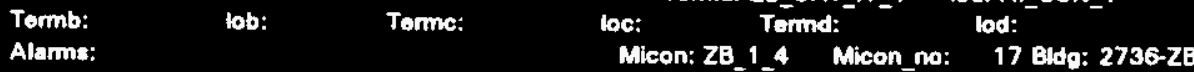

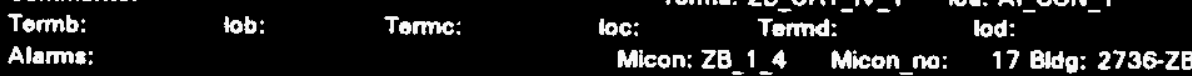
Loopbun: Vesed: ZB

Ai: 1 Aa: O Di: O Do: 0 Lculoc: RM 602

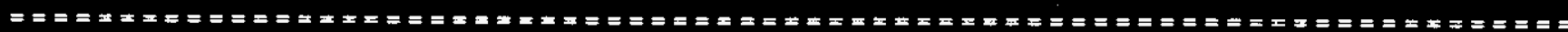
Old pid: 80167-2 Now pid: Devnum: AMP-SF-1 Devtypo: TRANS AMP Devtun: SUPPLY FAN 1 AMPS Devtoc: RM 602 12002 Intrange: 4-20 MA Statu: Comments:

Termb: Sofoty: 3 Loop: II_SF_1 Lovtypo: TRANS AMP Dov

lob: Tomc: loc: Tormd: lod:

Micon: ZB_1_4 Micon_no: 17 Bldg: 2736-ZE

Ai: 1 Ao: 0 Di: 0 Do: 0 Lcubc: AM 602

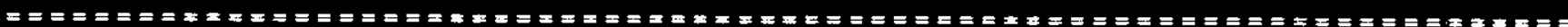
Old_pid: 80167-2 Now_pid: Intrange: 4-20 MA Stotus:

Comments:

Tomb:

Alarms: Dovnum: AMP-S Safoty: 3 Loop: II SF 


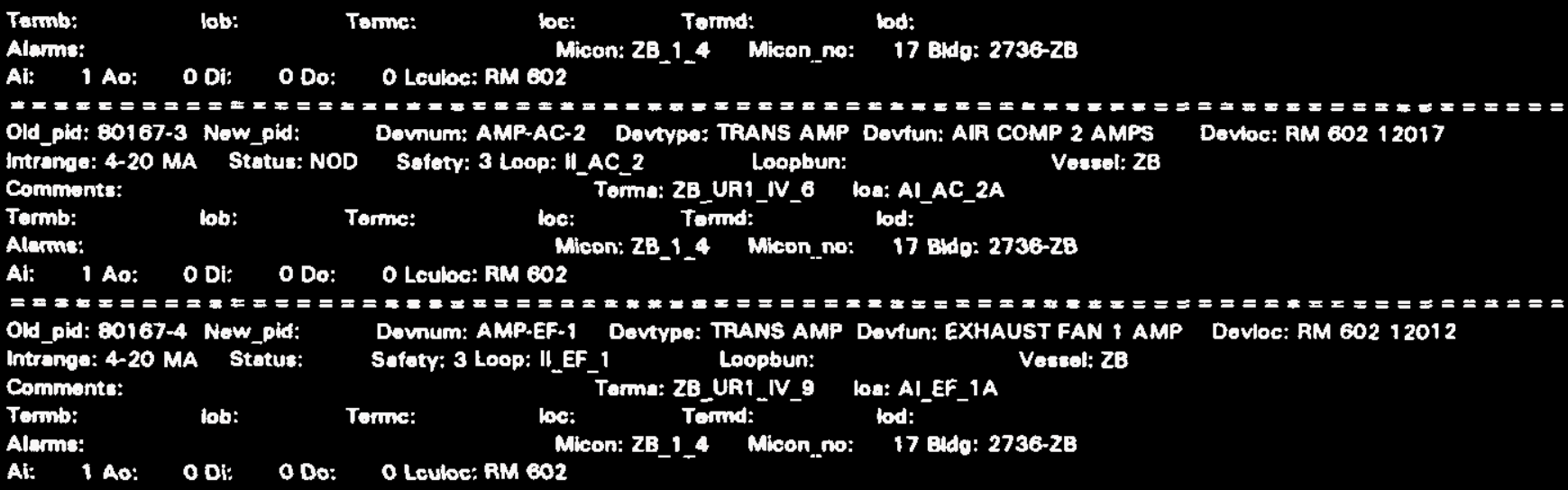

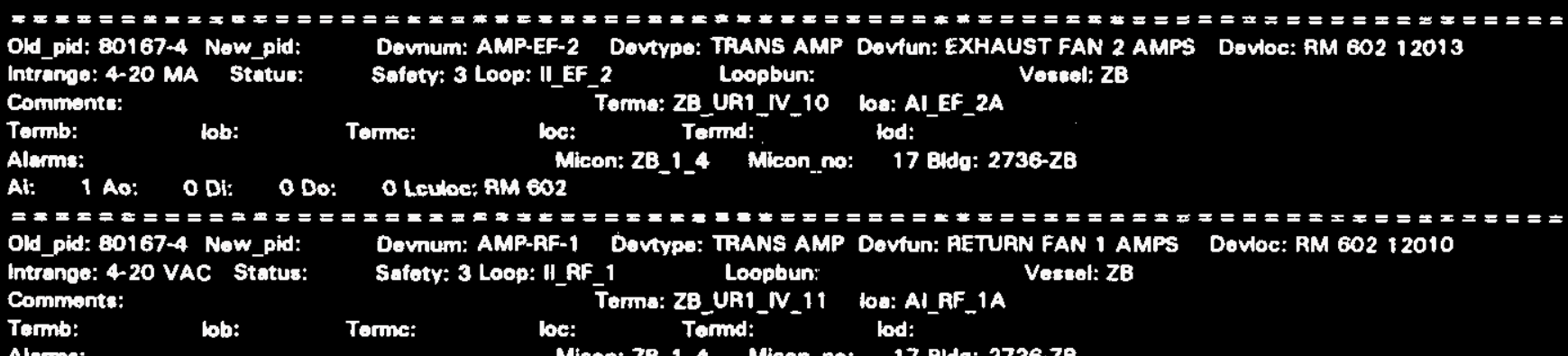

Micon: 28_1_4 Micon_no: 17 Eldo: 2736-2B

Ai: 1 Ao: 0 Di: 0 Do: 0 Leuloc: RM 602

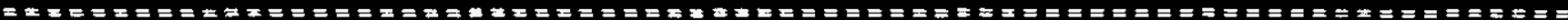

Intrand: 4-20 MA Status: Safoty: 3 Loop: II_AF_2
Commonte:

Tomb: lob: Tormc: loc: Tormd:

Alams: $\quad$ Mieon: 2B_1_4 Micon_no: 17 Bidg: 2736-28

Ai: 1 Ao: 0 Di: 0 Do: 0 Lculoc: AM 602

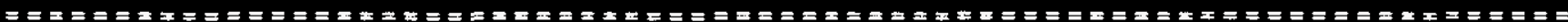
Old_pid: 80167-5 Now_pid: Dovnum: AMP-EF-1-1 Dovtypo: TRANS AMP Deviun: EXHAUST FAN 1-1 AMPS Dovoc: AM 602 12305 Intrange: 4-20 MA Status:

Commonte: Safoty: 3 Loop: If_1_1 Loopbun: Veasel: ZB

Tormb: lob: Terme: loc: Terma: ZB_UAt_IV_15 loa: Al_1_tA

Alems: $\quad$ Micon: Z8_1_4 Micon_no: 17 Bids: $2736-28$

Ai: 1 Ao: 0 Di: 0 Do: 0 Lculoc: AM 602

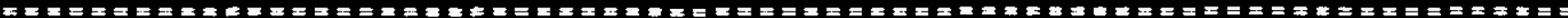
Old_pid: B0167-5 Now_pid: Dovnum: AMP-EF-1-2 Dovtype: TRANS AMP Dovfun: EXHAUST FAN 1-2 AMPS Devioc: RM 602 12306 htrange: $4-20 \mathrm{MA}$ Status:

Comments:

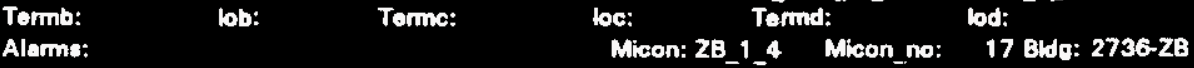
Stety: 3 Loop: II 12 Loopbun:

Vessel: Z8

Ai: 1 Ao: 0 Di: 0 Do: 0 Leuloc: AM 602

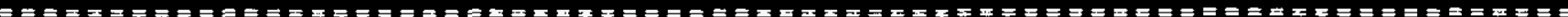

Old_pid: 80167-5 Now_pid: Dovnum: AMP-SF-5 Dovtypo: TRANS AMP Dovfun: SUPPLY FAN 5 AMPS Dovoc: RM 602 12006

Intrange: 4-20 MA Status: Safaty: 3 Loop: II_SF_5
Comments:

Termb: lob: Torme: loc: Tormat: lod:

Alarms: $\quad$ Micon: Z8_1_4 Micon_no: 17 Bido: $2736-28$

Ai: 1 Ao: O Di: O Do: OLculoc: RM 602

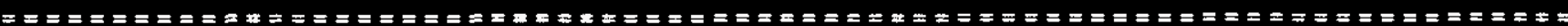

Old_pid: 80167-5 Now_pid: Dovnum: AMP-SF-6 Dovtype: TRANS AMP Dovfun: SUPPLY FAN 6 AMPS Dovloc: RM 602 12007

Intranga: 4-20 MA Status: Safoty: 3 Loop: II SF_6 Loopbun: VE

Comments: $\quad$ Toma: Z8_UA1_IV_1B loa: AI_SF_6A

Termb: lob: Torme: loc: lod:

Alarms: $\quad$ Micon: ZB_1_4 Micon_no: 17 Bida: 2736-ZB

Ai: 1 Ao: 0 Di: 0 Do: 0 Lculoc: RM 602

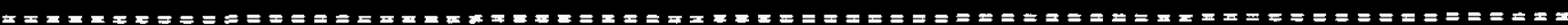
Old_pid: $80167-5$ New_pid: Devnum: AMP.VP-1 Devtype: TRANS AMP Devtun: VAC PUMP 1 AMPS

Intranee: 4-20 MA stotur: NOD

Dovloc: RM 60212014

Comments: SEE H-2-80159-2

Tormb:

Safoty: 3 Loop: II VP

Terma: ZB_UR1_IV_18 los: AI_VP_1A

Alarma:

lob:

Torme:

lac: Tormd: lod:

Micon: 2B_1_4 Micon_no: 17 Bidd: 2736-2B 
Ail: 1 Ao: 0 Di: 0 Do: 0 Lculoc: AM 602

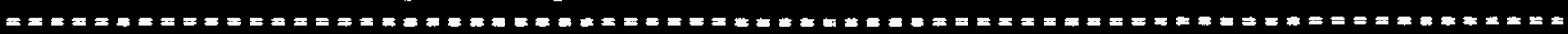
Old_pid: 80167-6 Now_pid: Downum: AMP-COND-2 Dovtype: TRANS AMP Dovfun: CONDENSER 2 AMPS Dovloc: RM 602 12001 Intrange: 4-20 MA Stetus: NOD Safoty: 3 Loop: II_COND2 Voasel: 28 Commante:

Tormb: lob: Torma: 28_UA1_IV_21 lon: Al_CON_2 Alerms: $\quad$ Micon: Z8_1_4. Micon_no: 17 Bldg: $2736-28$

Ai: 1 Ao: 0 Dl: 0 Do: 0 Lculoc: RM 602

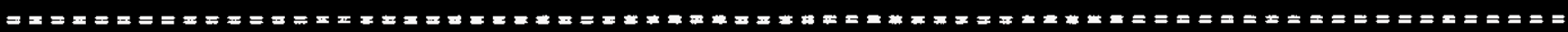
Old_pid: 80167-6 Now_pid: Dovnum: AMP-SF-3 Dovtypo: TRANS AMP Dovfun: SUPPLY FAN 3 AMPS Dovoc: RM 602 12004 Intrenge: 4-20 MA Status: Commenta:

$\begin{array}{llll}\text { Termb: } & \text { lob: } & \text { Terme: } & \text { Ternd: } \\ \text { Alarms: } & & \text { Micon: ZB_1_4 Micon_no: 17 Bddo: 2736-ZB }\end{array}$ Safoty: 3 Loop: II_SF_3 Loopbun: Voseol: $\mathbf{Z B}$

Ai: 1 Ao: 0 Di: 0 Do: 0 Leuloc: RM 602

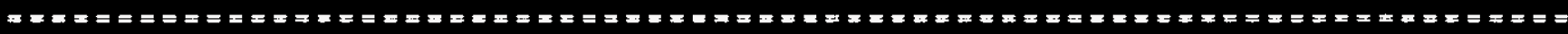
OHd pid: E0167-6 Now pid: Domum: AMP-SF.4 Devtype: TRANS AMP Dovtun: SUPPLY FAN 4 AMPS Dovoc: RM 602 12006 Intrange: 4-20 MA Status: Commants:

Tomb: lob: Terme: loc: Tormd: ${ }^{2}$ lod: Safoty: 3 Loop: II_SF_4 Loopbun: Versel: $\mathbf{Z B}$ Alame: $\quad$ Micon: 28_1_4 Micon_no: 17 Bldo: $2736-28$

Ai: 1 Ao: O Di: O Do: O Leuloc: AM 602

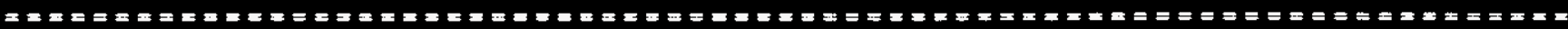
Ord_pid: 96418-5 Now_pid: Dovmum: TE-1 Intrange: Stetus: Sofot 4 Loop: TI TST Commants: 100 OHM PLATNUM PAOBE

Tormb: lob: Torme:

Alome: HI

Ai: 1 Ao: 0 Di: O Do: 0 Leuloc: AM 321A

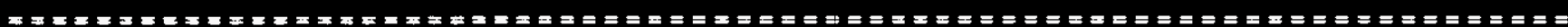
Old_pid: 80167-5 New_pid: Dovmum: PS-1-2 Devtype: SWTCH VAC Dovfun: LOSS OF VACUUM (17") Dovloc: RM 602 13414 Intranga: 24 VDC Status: NOD Safoty: 3 Loop: PA_PCR Loopbun: Vessel: ZB

Commente: SEE H-2-80141-9/10 Torma: ZB_UA2_VI_8 low: DI_1_2PS

Termb: lob: Tome: loc: Tornd: $\quad$ Ud:

Alarms: $\mathrm{Al}$ Ao: $0 \mathrm{Di}$ 1 Do: O Lculoc: AM 602 Micon: ZB_2_6 Mieon_no: 23 Bdo: 2736-20

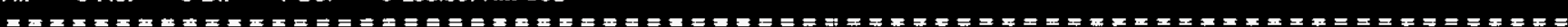
Old_pid: 26089-9 Now_pid: Dovnum: K-2A/28 Davtypo: SWTCH PAES Dovfun: EMER EXHAUST Dovloc: RM 321 A

Intrange: 120 VDC Stotus: Safety: 3 Loop: PAH_ET Loopbun: EV9 Vessel: HVAC

Commente: (WAS NS-1) SEE H-2-16318-2 ZONE E7 AND H-2-96434-5 Torma: 321_UA3_!_11 loa: DI_ET

Tormb: lob: locinc: loc lod:

Alarm: OVERRIDE THROUGH DO_EV9_2 (HS_SFi) Micon: RM321_3_1 Micon_no: 42 BIdd: $234-52$

Ai: $O$ AO: $O$ Di: 1 Do: O Leuloc: RM $321 \mathrm{~A}$

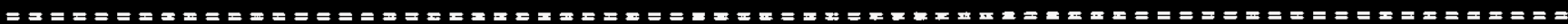
Old_pld: 80167-5 Now_pid: Dovnum: KF5-2-1 Dovtypo: SWTCH PAEs Devfun: EF-1-1 LOSS OF PAESS Dovoc: RM 321A PANEL M

Intrango: 120 VAC Status: NOD Sofoty: 3 Loop: FA_1 $1 \quad$ Loopbun: 1-1 Voesal: ZB

Comments: FS-1-1 iN 2736-ZB--SEE H-2-80159-3 (MAYBE NEW WIRES TO 2Bn Torma: 321 UA3_V_1 loa: DI_KSF21

$\begin{array}{lll}\text { Termb: } \quad \text { lob: } \quad \text { Torme: } & \text { Tormd: } \\ \text { Alarms: } & & \text { Micon: AM321_3_5 Micon_no: } 46 \text { Bidg: } 234-52\end{array}$

Ai: 0 Ao: 0 Di: 1 Do: 0 Lculoc: AM $321 \mathrm{~A}$

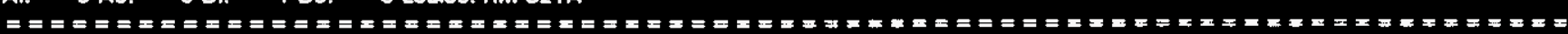

Old_pid: 80167.5 Now_pid: Dovmum: PS-2.1 Dovtypo: SWTCH PAES Dovfun: LOSS OF INST AIR Devloc: RM 602 12712

Intrange: 120 VAC status: Safoty: 3 Loop: PA_ZA_AC Loopbun: Veseal: ZB

Commente: 2736-ZA INSTRUMENT AIR COMFRESSOR Torma: ZB_UR2_II_4 loa: DI_2_1PS

Termb: lob: Torme: loc: Tormd:

Alarms: $\quad$ Micon: 2B_2_3 Micon_no: 20 Bldo: $2736-28$

Ai: 0 Ao: 0 Di: 1 Do: 0 Lculoc: AM 602

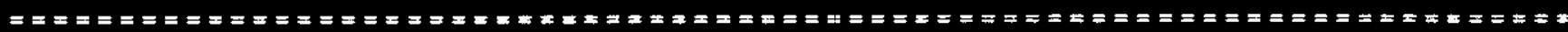
Old pid: 80167-6 Now pid: Dovnum: PS-8

Intrange: 24 VDC Status: Safoty: 3 Loop:

Commants: SEE H-2-80142-2

Termb:

lob:

Tarnc:

Dovtype: SWTCH PRES Devtun: NDA LAB PRESS

Voseal: ZB

Devloc: AM 60213307

Alarne:

Loopbun: EV-24A

Torma: 28 UA2 Y 10 loa: DI PS 8

Ai: 0 Ao: 0 Di: 1 Do: 0 Leuloc: $\mathrm{AM} 602$

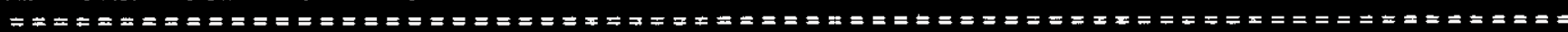
Old_pid: 82641 Naw_pid: 82641 Devnum: PSL-1

intrange: 120 VAC Statur: Safoty: 3 Loop: PAL-

Dovtype: SWTCH PAES Dovtun: FC-1/2 COOL WTA FAES Devloc: FC-1/2

Commants:

Tormb:

Terme: Loopbun:

Vessel: $\mathbf{8 6 8 0}$

Alarms: $\quad$ Micon: AM45_2_1 Micon_no: 11 8/dg: $243-28$

Ai: O Aa: O Di: 1 Do: O Lculoc: RM $45 / 6$

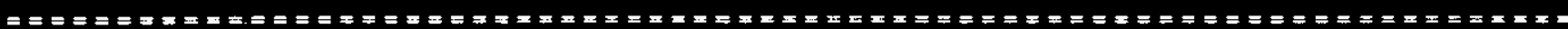
O4_pid: 82642-1 Now_pid: 82642-1 Devnum: PSL-TK101 Dovype: SWTCH PRES Devfun: TK-101 LOW PRESSURE Dovloc: RM 35 


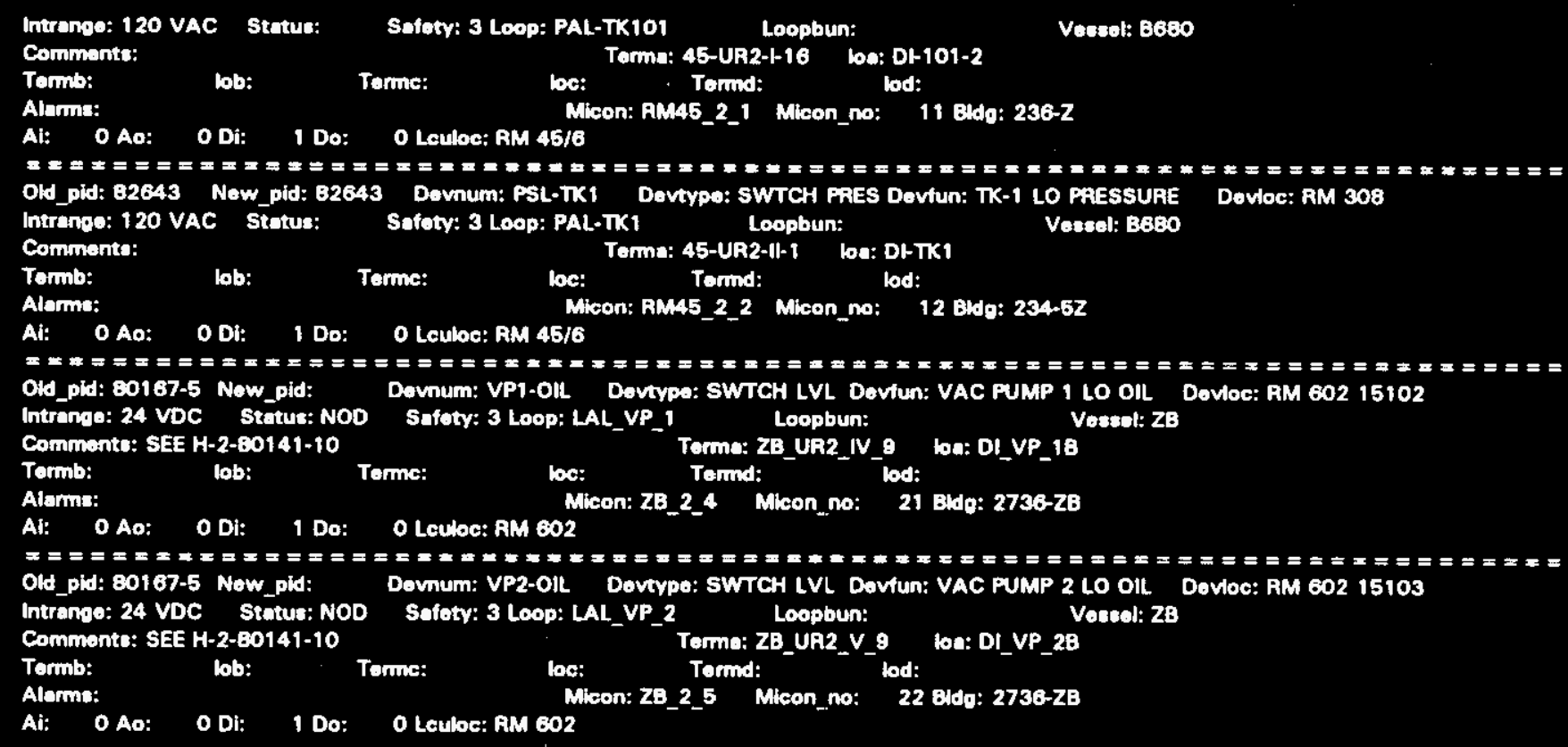




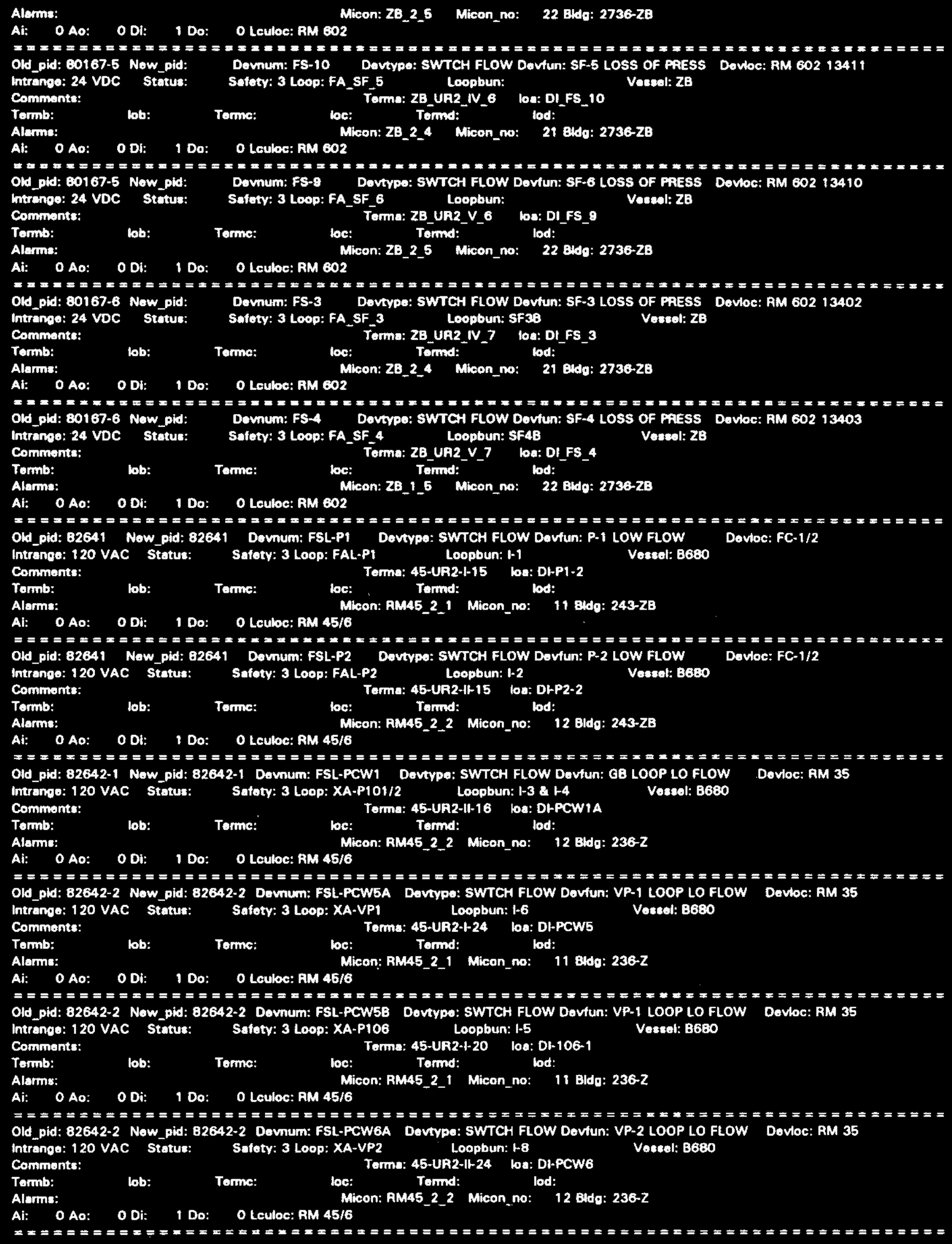


Old_pid: 82642-2 Now_pid: 82642-2 Dovnum: FSL-PCW6B Dovtype: SWTCH FLOW Dovfun: VP-2 LOOP LO FLOW Dovioc: AM 35 $\begin{array}{lll}\text { Intrange: } 120 \text { VAC Status: Safoty: } 3 \text { Loop: XA-P108 Loopbun: 1-7 } & \text { Vessel: B680 }\end{array}$

Comments:

Tormb:

lob: Torma: 45-UR2-11-20 lon: Or-108-1

loc: Tormd: lod:

Ai: O Ao: O Di: 1 Do: 0 Lculoc: AM 45/6

Micon: RM45_2_2 Micon_no: 12 Bldo: 236-2

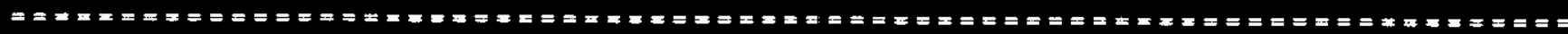
Old_pid: 82732 Now_pid: 82732 Dovnum: FS-1 Dovtype: SWTCH FLOW Dovłun: T-102 INLFT FLOW Dovloc: 243-2 Intronge: 120 VAC Status: Safoty: 3 Loop: FAL-102 Loopbun: Vessebl: B680 Commente:

Tormb:

lob:

Torme: Torma: 243-UA2-IIt-1 ba: Dr-3

Ai: O AO: O Di: 1 Do: 0 Micon: WTF_2_3 Mieon_no: 6 Bldg: 243-ZA

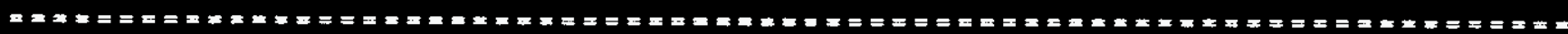
Old_pid: 82733 Now_pid: 82733 Dovnum: FS-2 Dovtype: SWTCH FLOW Dovtun: TRAIN 1 FLOW Imtrang: 120 VAC Status: Safoty: 3 Loop: FH TR-1 Comments:

Tormb: Terme: Loopbun: Vescol: $\mathbf{8 6 8 0}$

Dovloc: 243-2

Ai: O Ao: O Di: 1 Do: O Leubc: $243-2$

Torma: 243-UR2-11-20 laa: Dt-4

Micon: WTF_2_2 Micon_no: 5 Bida: $243-2$

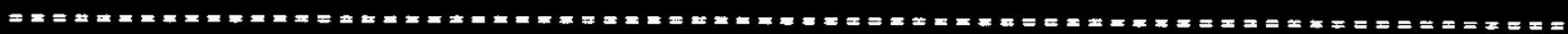
Old_pid: 82733 Now_pid: 82733 Dovnum: FS-3 Davtypo: SWTCH FLOW Dovfun: TRAIN 2 FLOW Intronge: 120 VAC Stetus: Safoty: 3 Loop: FP.TR-2 Commente:

Tormb: lob:

Torme: Loopbun: Vecesel: 8680

\section{Dovioc: $243-2$}

Alarme:

Ai: O Ao: O Di: 1 Do: O Leube: $243-2$

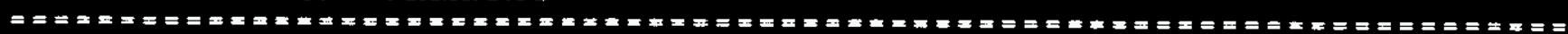
Old_pid: 82747 Now_pid: 82747 Dovnum: FS-4 Intrange: 120 VAC Statur: Safety: 3 Loop: fl-4 Comments:

Tormb:

Torme:

Dovypo: SWTCH F.

Torma: 243-UR2-1-20 loa: DH5

Tomnd: lod:

Micon: WTF_2_1 Micon no: 4 Budg: 243-7

Alarms:

Ai: $O$ Ao: 0 Di: 1 Do: 0 Leuloc: $243-2$

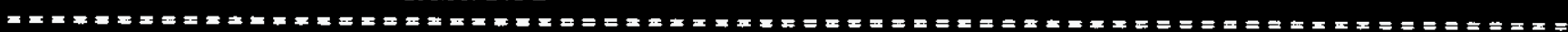
Old_pid: 80167 Now_pid: Dovnum: FA-2736-ZB Dovtypo: SWTCH FA Dovtun: 2736-ZB FIRE ALARM Dovloc: RM 602 13306

Intrange: 24 VDC Statua: NOD Satoty: 3 Loop: FA2736zB Loopbun: Vessel: ZB

Comments: SEE H-2-80142-2 AND H-2-80141-9/10

Tormb:

Torme:

UR2_V_2 loa: DI_FA_ZB

Vorsel: BG80

Alarma:

Al: O Ao: O Di: 1 Do: 0 Leuloc: AM 602

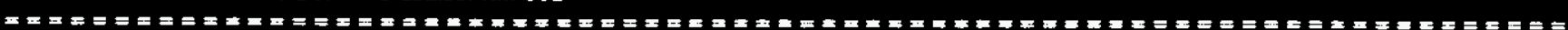
Old_pid: 60167 Now_pid: Dovnum: FA-ZN2 Dovtypo: SWTCH FA Dovfun: GEN FIRE ALAM ZN2 Dovloc: RM 60213304

Intrange: 24 VDC Statur: NOD Safoty: 3 Loop: FAZB_ZN2 Loopbun:

Commonts: SEE H-2-80142-2 AND H-2-80141-9/10

Tormb:

lob:

Tormc:

Torma: 2B_UA2_VI_2

Vessel: $2 \mathrm{~B}$

Alarme:

Al: OAo: O Di: 1 Do: 0 Leube: $\mathrm{RM} 602$

602

Old_pid: 80167 Now_pid: Dounum: FA-ZNB Dovtype: SWTCH FA Dovtun: NDA FIRE ALARM ZNB Dovloc: AM 602 13305

Intrange: 24 VDC Stotut: NOD Sofoty: 3 Loop: FAZB ZNB

Commonts: SEE H-2-80142-2 AND H-2-80141-9/10

Tormb:

Torme:

Terma: ZB_UA2_VI_3

Vocsel: ZB

Alarms:

Ai: O AO: O Di: 1 Do: O Leuloc: AM 602

602

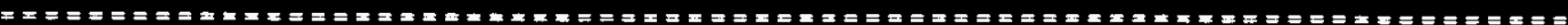
Old_pid: $80167-3$ Now_pid: Dovnum: DPS-1 Dovtype: SWTCH DP Dovfun: ZNI GBX PAES OFF NOA Dovloc: RM 60213416 Intrange: 24 VDC Status: Commente:

Tormb: lab: Torme: loc: Micon: ZB_2_4 Micon_no: 21 Bida: 2736-ZB Sofoty: 3 Loop: PDAL_12

Loopbun: EV23

Voscol: ZB

Ai: O AO: O DI: 1 Do: O Leuloc: AM 602

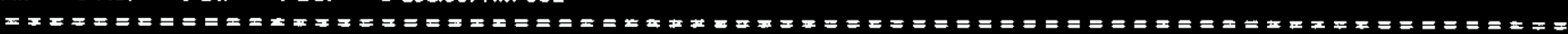
Old_pid: 80167-4 Now_pid: Devnum: DPS-2 Devtype: SWTCH DP Devfun: RF1/PF2 DP SWITCH Dovloc: AM 602 13417 Imtrange: 24 VDC Status: Safaty: 3 Loop:

Commente:

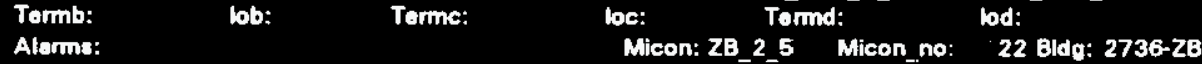

Vecel: $\mathbf{Z B}$

Ai: 0 Ao: O Di: 1 Do: 0 Leuloc: AM 602

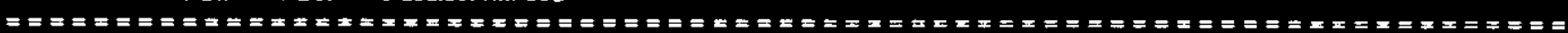
Old_pid: 96410-2 Now_pid: Dovnum: DPAS-1 Dovtypo: SWTCH DP Dovfun: HEPA FILTER H1 HI DP Dovloc: RM 321 A 26VAC

Intrang: 120 VAC Status: Safoty: 3 Loop: PDA

Comments: SEE H-2-28738

Safoty: 3 Loop: PDA_ 1 Loophun:

Torma: 321_UA3_IV_2 loa: DI_DPAS1

Vessel: 26VAC 


\section{WHC-SD-610-PSAR-002 REV 1}

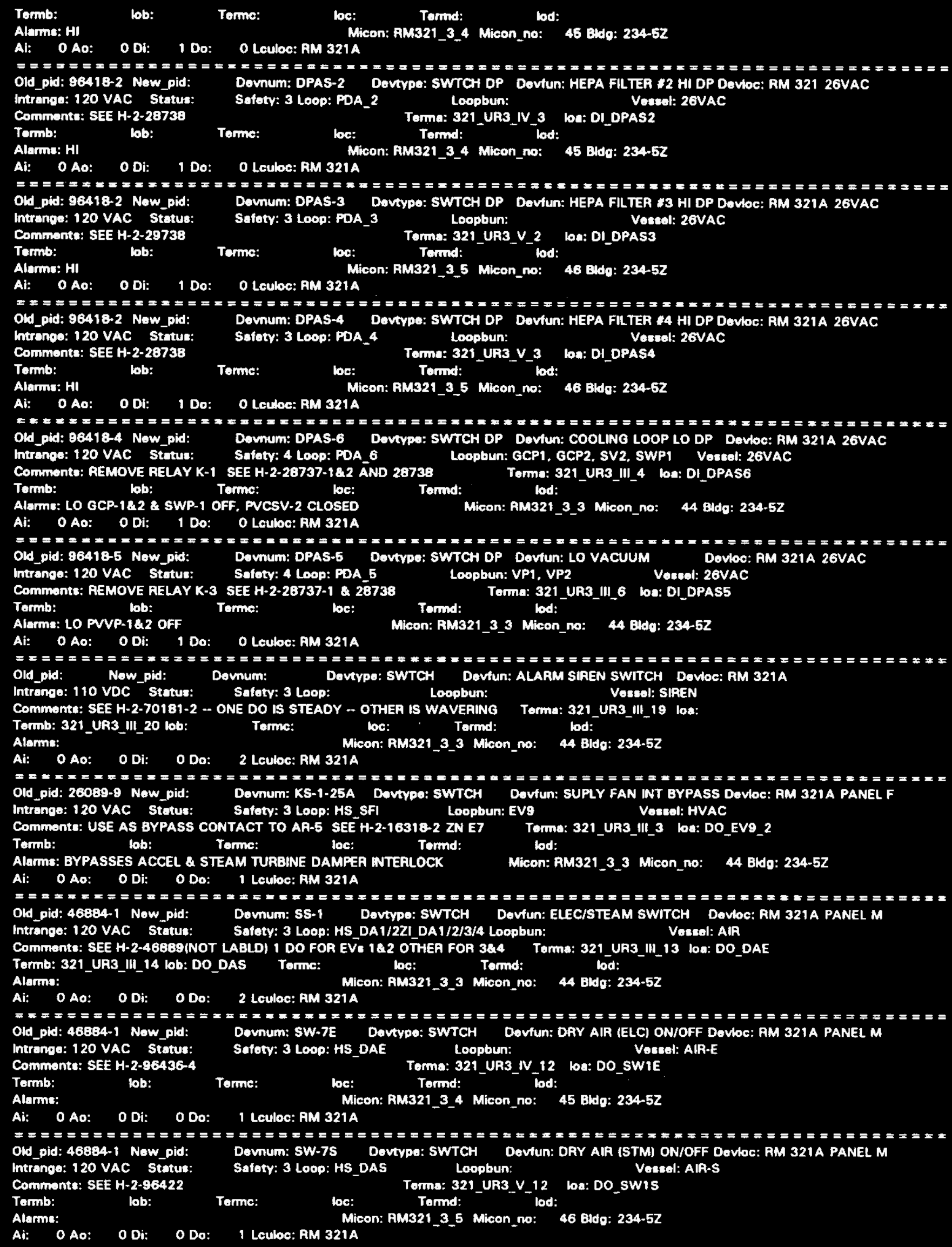




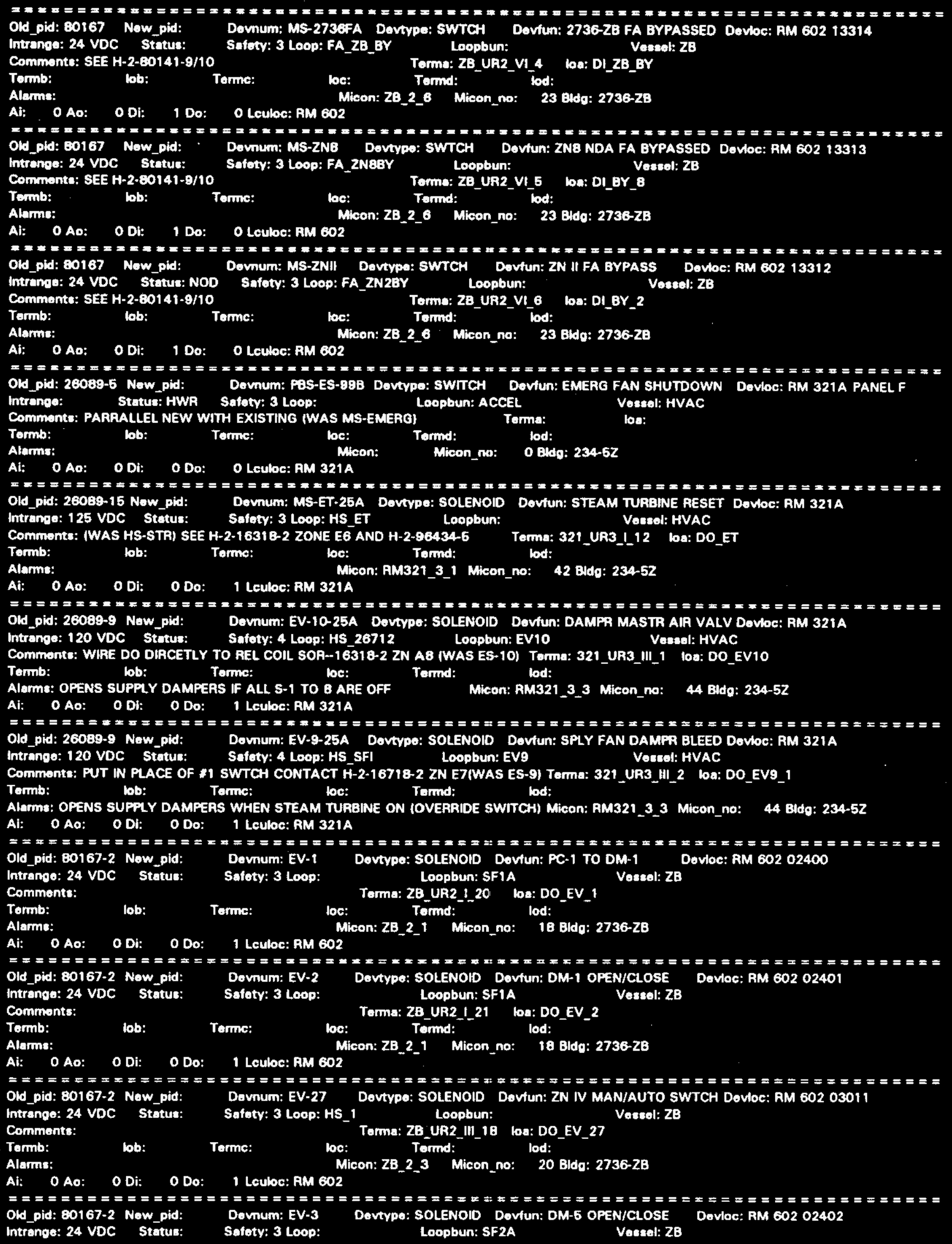




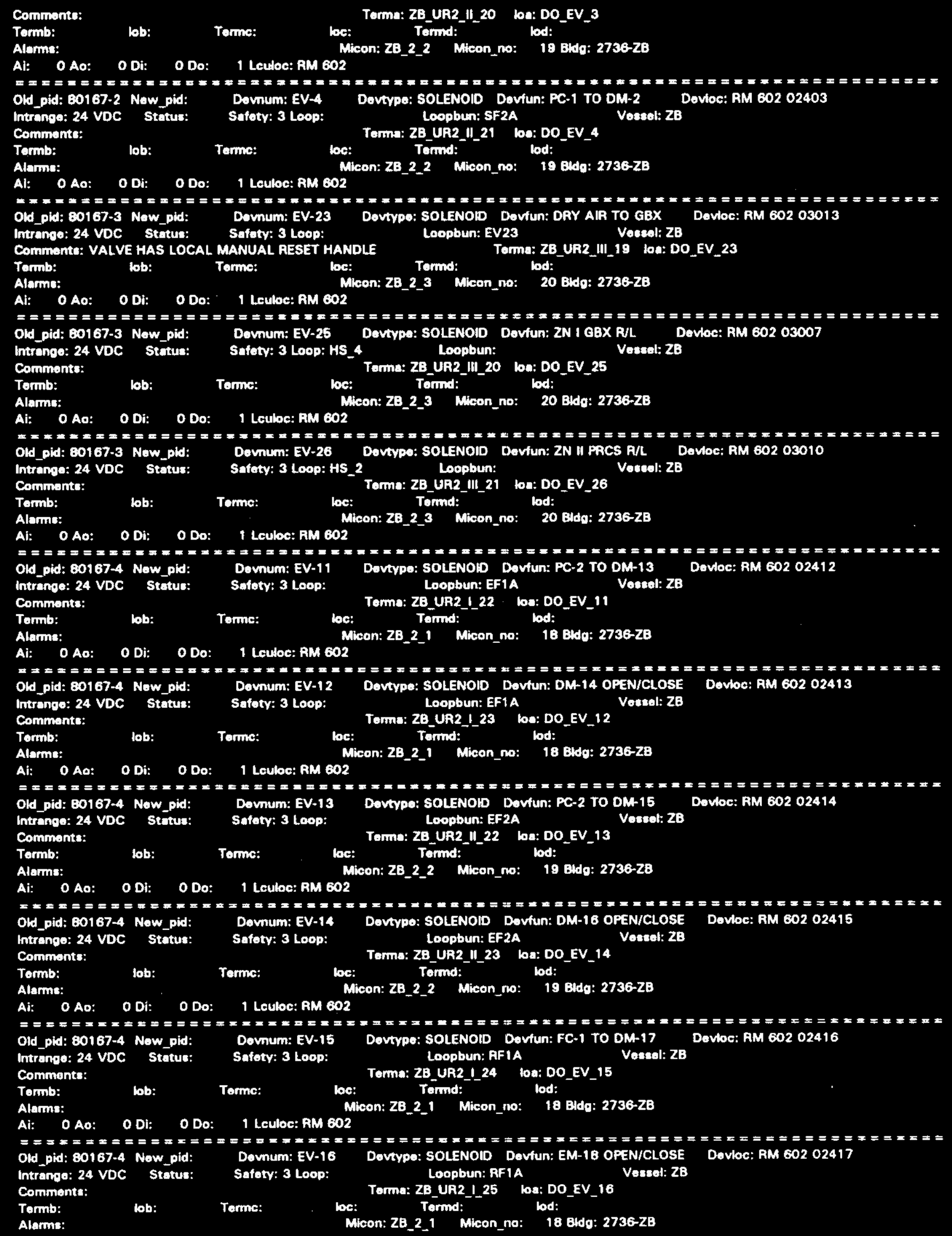


Ai: O Ao: O Di: O Do: 1 Leuloc: RM 602

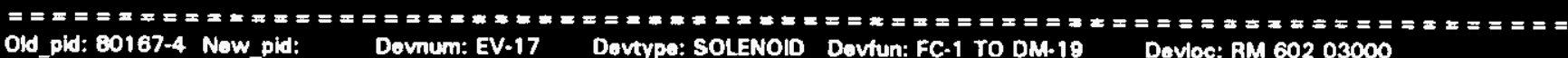
Intrange: 24 VDC Status: Safoty: 3 Loop: Comments:

Tomb:

Davtype: SOLENOID Dovfun: FC-1 TO DM.18 Devloc: RM 60203000 lob:

Terme: Loopbun: RF2A Vescel: ZB

Ai: OAa: O Di: ODo: 1 lauloc: AM Terma: 28_UR2_II24 los: DO EV_17 Tarmd: lod: $z=z=z=z=z=z=z=z=z=z=z=z=$ Old_pid: 80167-4 Now_pid: Dovnum: EV-18 Intrange: 24 VDC Status: Sofoty: 3 Loop: Micon: 28_2_2 Micon no: 19 Blda: 2736-Z8 Combinte:

Termb: lob:

Temp: Dovtye: SOLENOID Dovtun: DM-20 OPEN/CLOSE Dovloc: RM 60203001

Alarma:

Al: 0 Ao: 0 Di: 0 Do: 1 Lculoc: RM 602

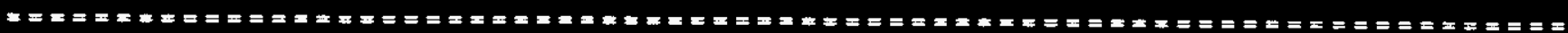
Old_pid: 80167-4 New_pid: Downum: EV-19 Dewype: SOLENOWD Devfun: DM-21/23/24 OPN/CLS Dovioc: RM 602 03002 Intronge: 24 VDC Status: Sofoty: 3 Loop: Comment: VALVE HAS LOCAL MANUAL RESET HANDLE Temm: bo:

Torme: Loopbun: EV19 Voctal: $\mathbf{2 B}$

Alarms: Torind: Torma: ZB_UR2_III_22 ba: DO_EV_19

Ai: OAo: O Di: 0 Do: 1 louloc: RM 602

(202

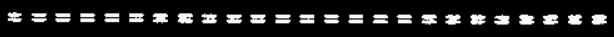

Old_pid: 80167-4 Now_pid: Davnum: EV-20

Intranoo: 24 VDC Status: Safoty: 3 Loop: Comments:

Tomb:

Terme:

Dovypo: SOLENOD Dovfun: WST AIR TO M2 Vescel: $\mathbf{Z B}$

Alarme: $\quad$ Micon: ZB_2_3 Micen_no: 20 Bidg: 2736-ZB

Ai: 0 Ao: 0 Di: 0 Do: 1 Lculoc: $\mathrm{AM} 602$

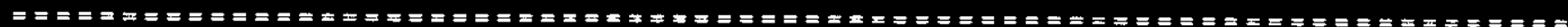
Old_pid: 80167-4 Now_pid: Dovnum: EV-21 Intranos: 24 VDC Status: Safaty: 3 Loop: Commente:

Tormb:

Alarme:

Ai: 0 Ao: O Di: 0 Do: 1 Leuloc: RM 602

-2.3.

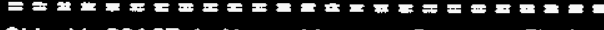

Old_pid: 80167-4 Now_pid: Devnem: EV-22

Intrange: 24 VDC Status: Safety: 3 Loop:

Commonts:

Termb: Safoty: 3 Loop:

Davtypo: SOLENOID Dovfun: INST AIR To $\mathrm{m}$ Davioc: AM 60203004

Alarms: $\quad$ Micon: Z8_2_3 Micon_no: 20 Bldg: $2736-28$ Ai: 0 Aa: 0 Di: 0 Do: 1 Leuloc: RM 602

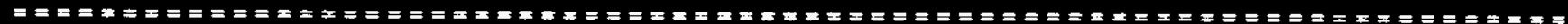
Old_pid: 80167-4 Now_pid: $\quad$ Devmum: EV-28 Dovtype: SOLENOID Dovfun: EXH PLNM PAESS R/L Dovloc: RM 602 O3012
Intrange: 24 VDC Status: Intrange: 24 VDC Status:

Comments: Looptun: EV21 (EF-1/2) Veasel: 28 Dovbc: AM 60208003

Tormb: Terma: ZB_UA2_111_26 loa: DO_EV_28

Alarms: $\quad$ Micon: 28_2_3 Micon_no: 20 Bldo: $2736-28$ Ai: 0 Aa: 0 Di: 0 Do: 1 Lculoc: RM 602

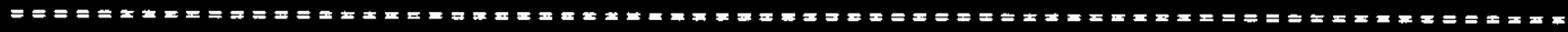
Old_pid: 80167-5 Now_pid: Devnum: EV-10 Devtypo: SOLENOID Devfun: DM-12 OPEN/CLOSE Devloc: RM 602 02411 Intrange: 24 VDC Stotus: Safoty: 3 Loop: Commente:

$\begin{array}{lll}\text { Termb: lob: } \quad \text { Tormc: } & \text { Tormd: } \\ \text { Alarma: } & & \text { Micon: ZB_2_2 Micon_no: 19 Bldo: 2736-2B }\end{array}$ Loopbun: SF6A Vensol: ZB

Ai: 0 Ao: 0 Di: 0 Do: 1 Leuloc: AM 602

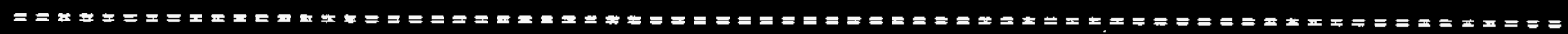
Old_pid: 80167-5 Now_pid: Dovnum: EV-28 Intrande: 24 VDC Status: Satoty: 3 Loop: Commente:

$\begin{array}{llll}\text { Termb: lob: } \quad \text { Terme: } & \text { Termd: } & \text { Micon: ZB_2_3 Micon_no: 20 Bdo: 2736-ZB }\end{array}$

$\begin{array}{lll}\text { Termb: lob: } \quad \text { Terme: } & \text { Tormd: } & \text { Micon: ZB_2_3 Micon_no: 20 Bdo: 2736-ZB } \\ \text { Alarms: } & & \end{array}$

Terme: Loopbun: EV29 (SF5/6) Vaseal: ZB

Ai: O Ao: O Di: O Do: 1 Leuloc: AM 602

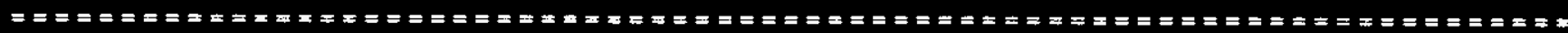
Old pid: 80167.5 Naw pid: Devnum: EV-30 Intrange: 24 VDC Status: Commentu:

Tormb: Safaty: 3 Loop: HS 6

Dovtypo: SOLENOID Davfun: 2736-2 PRESS R/L Dovioc: RM 60203600

Alarms:

Ai: O Ao: O Di: O Do: 1 Lculoc: AM 602

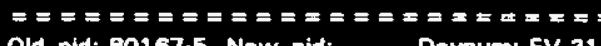

Old_pid: 60167.5 Now_pid:

Davnum: EV-31

Davypo: SOLENOID Devfun: DM-26 OPEN/CLOSE

Devloc: AM 60203601 


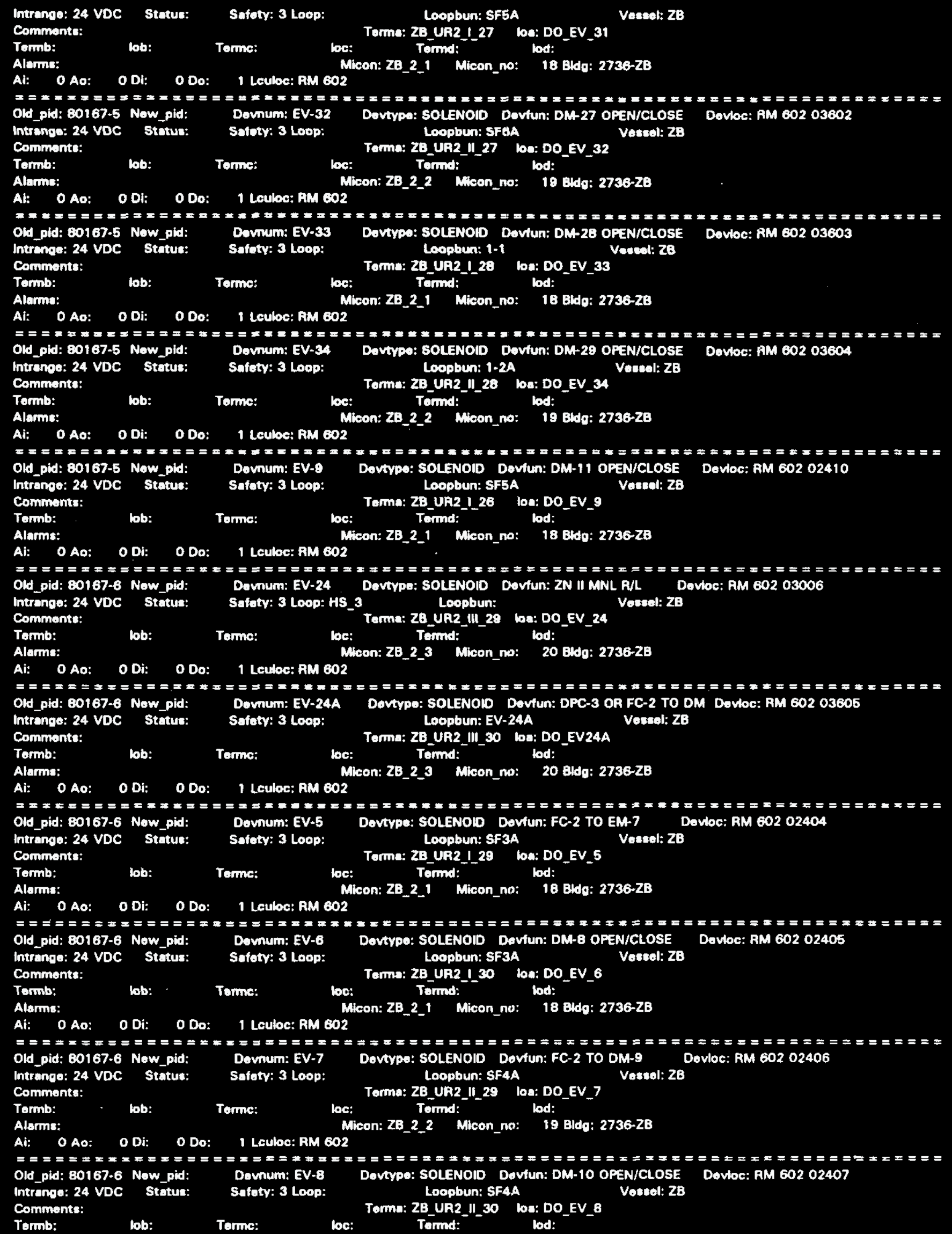




\section{WHC-SD-610-PSAR-002 REV 1}

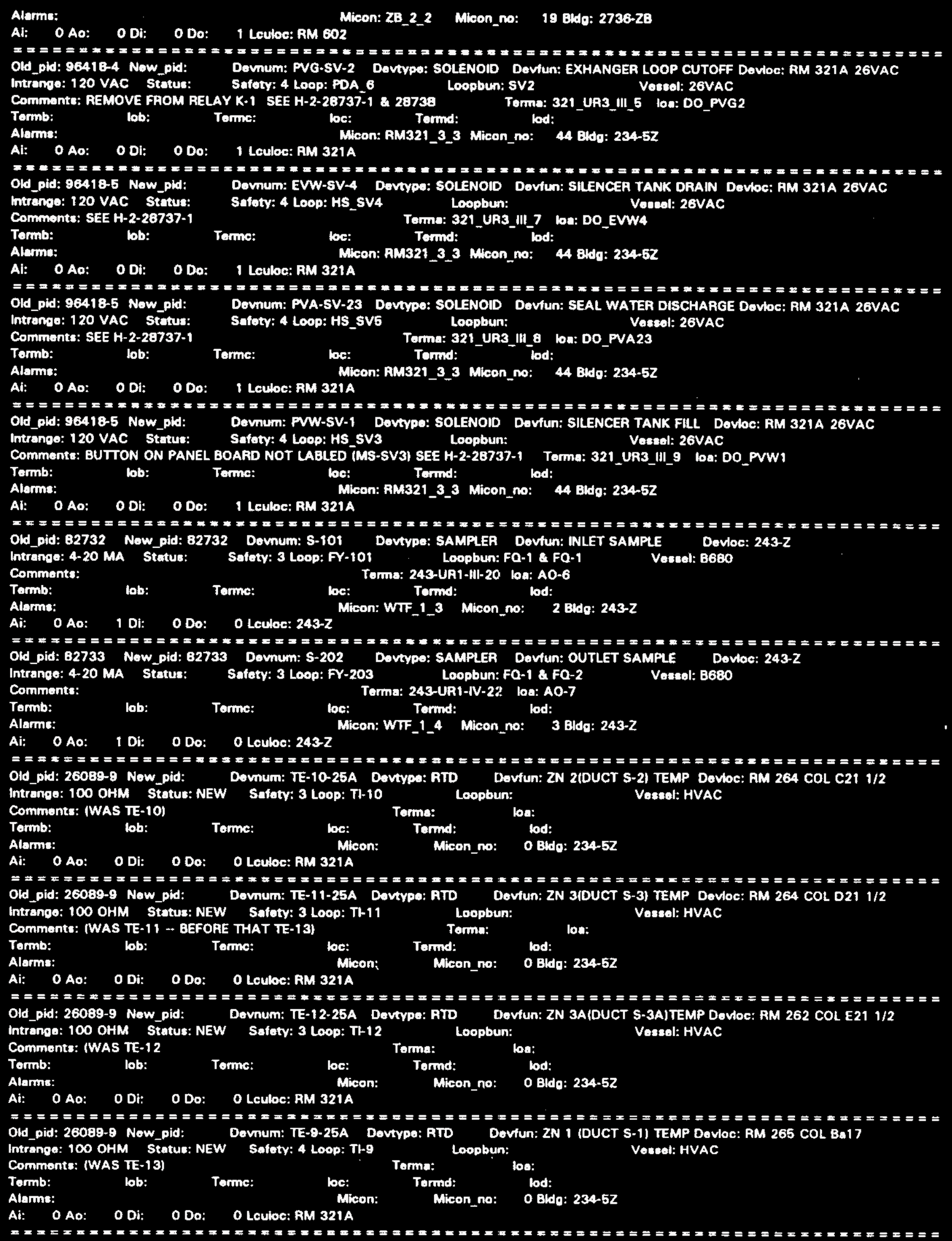


Old_pid: 80167-5 Now_pic: Intrangs: 120 VAC Status:

Dovmum: KFS-1-1 Devtype: AELAY Dovfun: EF-1-2 LOSS OF PFESS Dovoc: RM 321A PANEL M Looptun: 1-2A Vescol: ZB

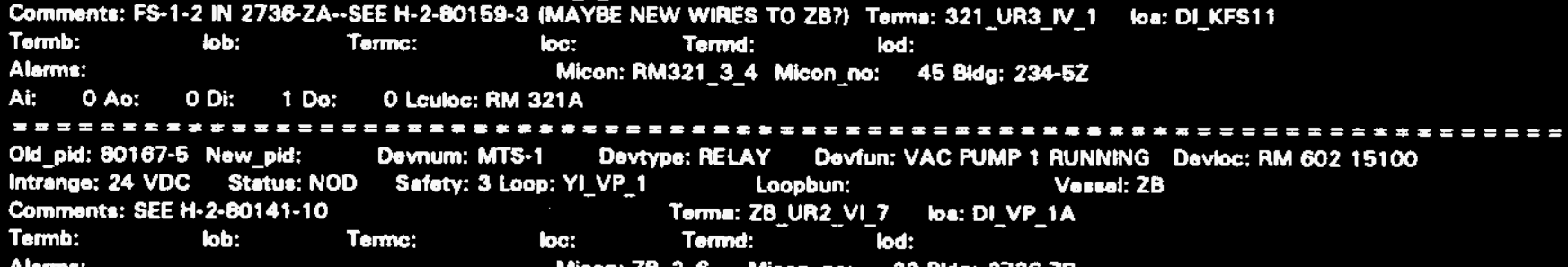

Micon: Z8_2_6 Micon_no: 23 Bidg: 2736-28

Al: 0 AO: $O$ Di: 1 Do: 0 Leube: RM 602

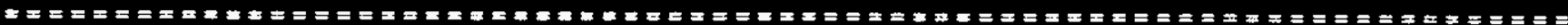
Old_pid: 80167-5 Now_pid: Dovmum: MTS-2 Dovtypo: RELAY Dovtun: VAC PUMP 2 RUNNING Davioe: RM 60215101

Intrenge: 24 VDC Status: NOD

Commonta: SEE H-2.60141-10

Tormb:

Safoty: 3 Loop: YIVP_2

Loopbun:

Torma: Z8_UA2_V1_8 loo: OI_VP_2A

Micon: ZB_2_6 Micon_no: 23 BIda: 2736-ZB

Ai: 0 Ao: 0 Di: 1 Do: 0 Leuloc: RM 602

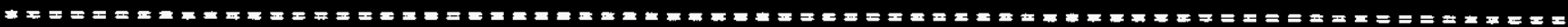

Old_pid: 96418-3 Now_pid: Dovmum: 1K1 Dovtypo: RELAY Dovtun: LEAK DETECT ALARM Dovoc: RM 321A PANEL 1

Intranga: 120 VAC Stotus: Sifoty: 3 Loop: CA_ILDA Loopbun: 1LD Voscol: 26VAC

Comments: SEE H-2-28087-2 - LEAVE EXISTING RELAY Torma: 321_UA3_IV_4 lon: DI_1LDA

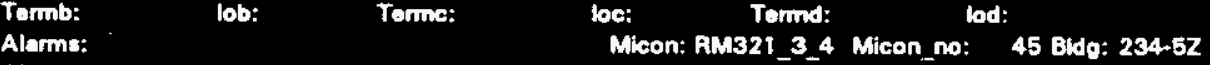

Ai: O Ao: O Di: I Do: O Leube: RM 321A

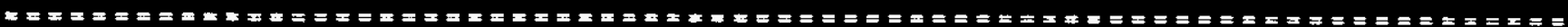

Old_pid: 96418-3 Now_pid: Downum: IK2 Dovtype: RELAY Dovtun: LD FAILURE ALARM Dovioc: RM 321A PANELL

Intrange: 120 VAC Stotue: Safoty: 3 Loop: XA_1LDB Loopbun: 1LD Voseal: 26VAC

Commonts: SEE H-2-28087-2 - LEAVE EXISTING RELAY $\quad$ TOrmo: 321_UA3_IV_5 los: DI_1LDB

$\begin{array}{llll}\text { Termb: } & \text { lob: } & \text { Terme: } & \text { loc: } \\ \text { Alarms: } & & & \text { Micon: RM321_3_4 Micon_.no: } 45 \text { Bldg: 234-5Z }\end{array}$

Ai: O Ao: O Di: 1 Do: O Leuloc: RM 321A

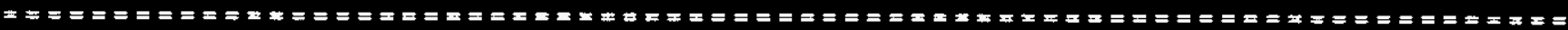
Old_pid: 96418-3 Now_pid: Devnum: 2K1 Dovtypo: RELAY Dovfun: LEAK DETECT ALARM Dovloc: RM 321A PANEL L

Intrange: 120 VAC Status: Safoty: 3 Loop: CA_2LDC Loopbun: 2LD Vossol: 26VAC

Comments: SEE H-2-28087-2 -- LEAVE EXISTING AELAY Torma: 321_UR3_V_4 loa: DI_2LDC

$\begin{array}{lll}\text { Tormb: lob: } \quad \text { Tormc: } & \text { Tormd: Micon: RM321_3.5 Micon_no: } 46 \text { Bddg: 234-52 } \\ \text { Alarms: } & & \text { lod: }\end{array}$

Ai: O AO: O Di: 1 Do: O Leuloc: AM 321A

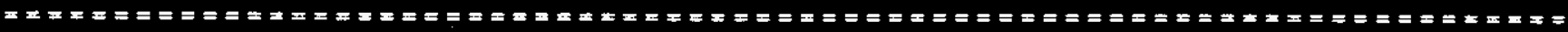
Old_pid: 96416-3 Now_pid: Dovnum: 2K2 Dovtypo: RELAY Dovfun: LD FAlL ALARM Dovloc: RM 321A PANEL L

Intrange: 120 VAC Status: NOD Satoty: 3 Loop: XA_2LDD Loopbun: 2LD Vosect: 26VAC

Commonts: SEE H-2-20087-2 - LEAVE EXISTING RELAY Torma: 321_UA3_V_5 loa: DI_2LDD

$\begin{array}{lll}\text { Tormb: lob: Torme: loc: Micon: AM321_3.5 Micon no: } 46 \text { Bldo: 234-6z } \\ \text { Alarms: } & & \text { lod: }\end{array}$

Ai: $\quad$ Ao: $\quad$ O Di: 1 Do: 0 Lculoc: RM $321 \mathrm{~A}$

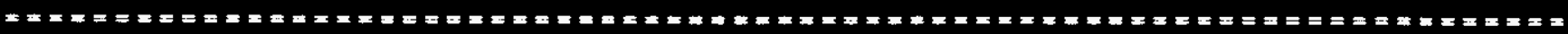
Old_pid: NONE Naw_pid: NONE Dovnum: OWS1 PEN 3 Dovtypo: RECORDER Dovtun: RECORDER PEN Intrange: 1-5 VDC Status: Safoty: 4 Loop: OWS1 Loopbun: Commente:

Tormb: Termo: 262-UA1-IIt-21 los:

Alorms: $\quad$ Micon: RECOADER 1 Micon no: 0 sidd: 234-5ZA

Ai: O Ao: 1 Di: 0 Do: 0 Leuloc: PM $262 E$

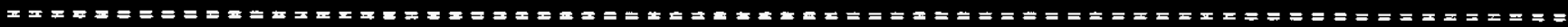
Old_pid: NONE Now_pid: NONE Dovnum: OWS1 PEN-1 Dovtype: RECORDER Dovtun: RECORDER PEN Intrange: 1.5 VDC Stutus: Sofety: 4 Loop: OWS1 Loopbun: Veesel: PEC Commente:

Tormb:

Micon: RECORDER_ 1 Micon_no: 0 Bldg: 234-52 A

Ai: OAo: 1 Di: O Do: O Leuloc: RM.262E

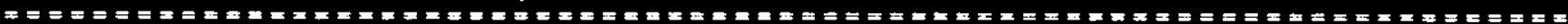
Old_pid: NONE Now_pid: NONE Dovnum: OWS1 PEN-2 Dovtypo: RECORDER Dovtun: RECORDER PEN Intrange: 1.5 VDC Status: Safoty: 4 Loop: OWS1 Loopbun:

Comments: $\quad$ Torma: 262-UR1-IIt-20 loa:

Termb: lob: Torme: loc: Tornd: lod:

Alarms: $\quad$ Micon: RECORDER_1 Micon_no: O Bldg: 234-52A

Ai: O Ao: 1 Di: O Do: O Leube: RM $262 E$

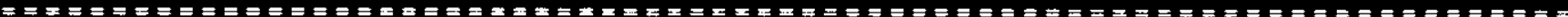
Old_pid: NONE Now_pid: NONE Dovmum: OWS1 PEN-4 Dovtypo: RECORDER Dovfun: RECORDER PEN Intrange: 1.5 VDC Status: Safoty: 4 Loop: OWS1 Loopbun: Commente: Torma: 262-UA1-lit-22 loa: 


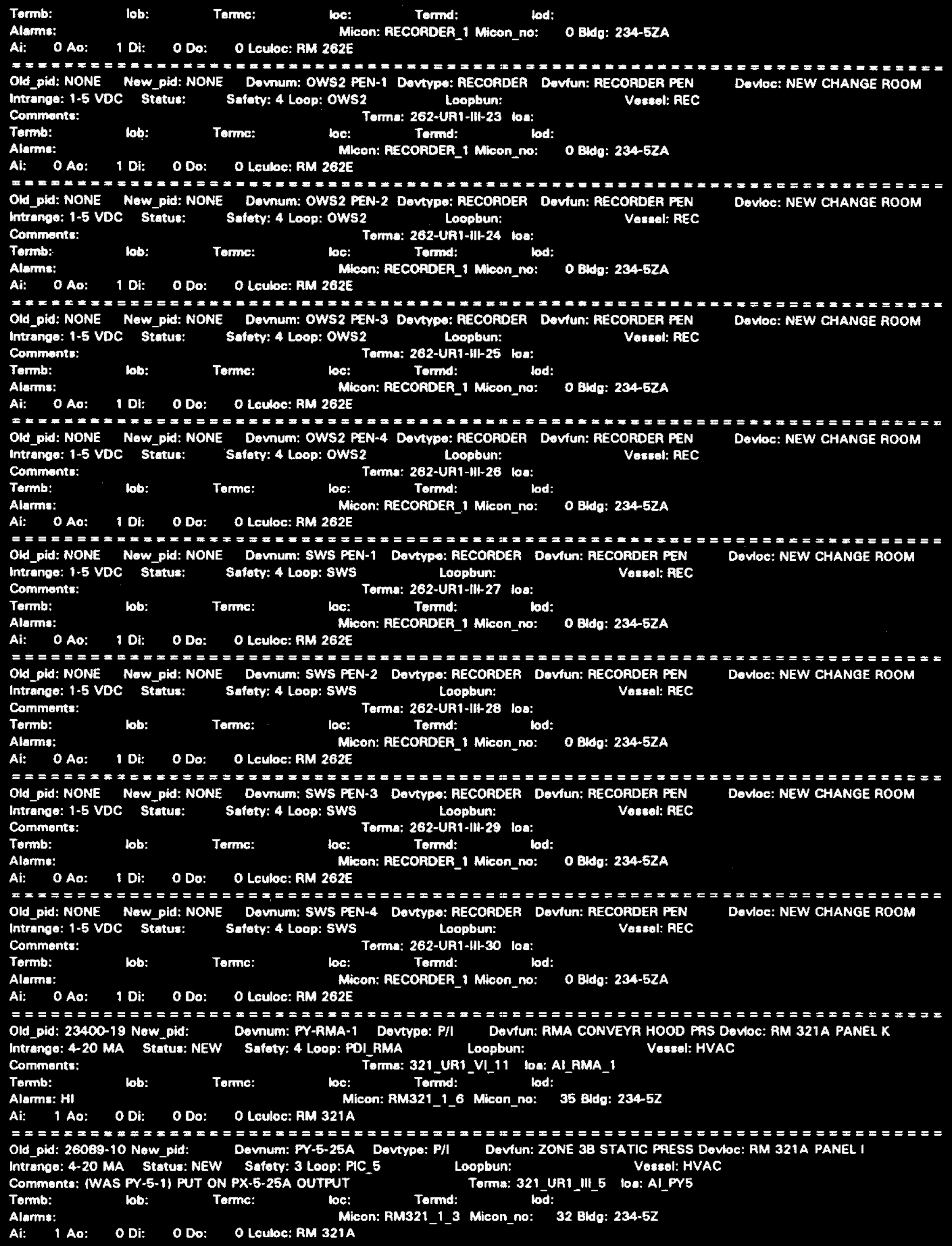


Old_pid: 26089-10 Now_pid: Dovnum: PY-6-25A Devtype: P/I

Intrango: 4-20 MA Statur: NEW Safoty: 3 Loop: PC_6

Commonte: (WAS PY-236-1) PUT ON PX-6-25A OUTLET

Tormb:

lob:

Torme:

loc:

Alarma: $\quad$ Micon: AM321_1_3 Micon_no: 32 Bkds: 234-62

Ai: 1 Ao: 0 Di: 0 Do: 0 Lculoc: AM 321A

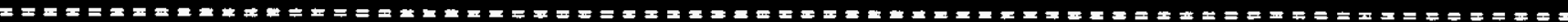
Old_pid: 26089-9 Now_pid: Dovnum: PY-1-25A Dovtypa: P/

Intrange: 4.20 MA Status: NEW Safoty: 4 Loop: PIC-1

Deviun: ZONE 1 STATIC PAEsS Dovioc: RM 321 A PANEL 6

Voscol: HVAC

Comments: (WAS PY-1-1) PUT ON PX-1-25A OUTLET (AEPLACES PC-1-25A) Torma: 321_UA1_II_2 los: AI_PY1

Tormb: bb: Torme: be: Tormd: lod:

Alarms: $\quad$ Micon: AM321_1_3 Micon_no: 32 Blda: $234-52$

Ai: 1 Ao: $\quad$ Di: $\quad$ Do: 0 Leuloc: AM 321A

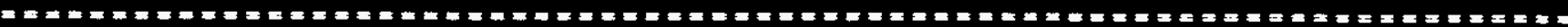
Old_pid: 26089-9 Now_pid: Dovnum: PY-2-25A Dovtypa: P/

Intrange: 4-20 MA Status: NEW Safety: 3 Loop: PIC-2

Commente: (WAS PY-2-1) PUT ON PX-2-25A OUTLET

Tormb: lob: lorme: loc:

Tormd: lod:

Alarms: 1 Ao: O Di: O Do: OLculoc: AM 321A

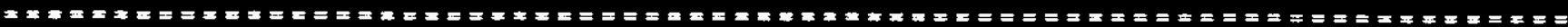
Old_pid: 26089-9 Now_pid: Davnum: PY-4-25A Dovtypo: P/I Doviun: ZONE 3A sTATIC PAESS Dovloc: RM 321A PANEL 1

Intrango: 4-20 MA Stotus: NEW Sofoty: 3 Loop: PIC-4 Loopbun: Voscel: HVAC

Commonte: (WAS PY-4-1) PUT ON PX-4-25A OUTLET Torma: 321 UA1_III4 ba: AI_PY4

Tormb: lob: Torme: loc:

Tormd: lod:

Alarms: $\quad$ Micon: AM321_1_3 Micon_no: 32 Bdds: 234-62

Ai: 1 Ao: O Di: O Do: O Leuloc: RM 321A

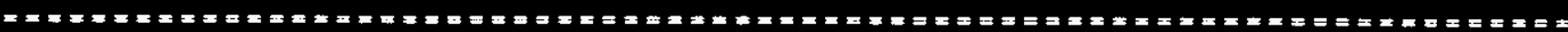
Old pid: 82641 Now,pid: 82641 Devnum: HV.SCW1 Dovtypo: MOTOR VALV Dovtun: FC-1 OUTLET Devloc: FC-1/2

Intrange: 120 VAC Stotus: Snfoty: 3 Loop: HS-SCWI Loopbun:

Voscol: $\mathbf{B} 680$

Commonta:

Tormn: 45-UA2-18 los: Dr-SCW1A

Tormb: 45-UA2-t9 lob: D+SCW1B Torme: 45-UR2-1-10 loc: Do-sCW1A Tornd: 45-UA2-11 lod: Do-SCW1B

Alarms:

Ai: 0 Ao: O Di: 2 Do: 2 Leuloc: $A M 45 / 6$

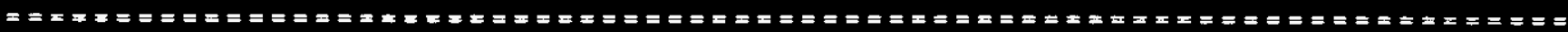

Old_pid: 82641 Now_pid: 82641 Devnum: HV.SCW2 Dovtype: MOTOR VALV Devfun: FC-2 OUTLET

Intrange: 120 VAC Statua: Safoty: 3 Loop: HS-SCW/2 Loopbun: Vossel: B680

Torma: 45-UA2-11-8 ba: DI-SCW2A

Tormb: 45-UR2-11-9 lob: DHSCW2B Torme: 45-UR2-11-10 loe: DO-SCW2A Tormd: 45-UA2-11-11 lod: Do-SCW28

Alarma:

Micon: RM45_2 2 Micon no: 12 Bdg: 243-28

Ai: 0 Ao: 0 Di: 2 Do: 2 Lculoc: RM 45/6

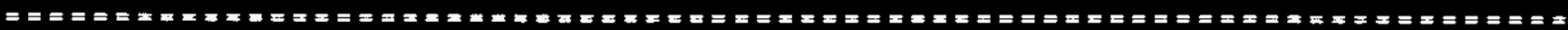

Old_pid: 82732 Now_pid: 82732 Dovnum: MOV-1

Intrango: 120 VAC Status: Sofoty: 3 Loop: HS-28

Davtypo: MOTOR VALV Dovtun: F-202A INLET

Dovloc: $243-z$

Commenta:

Torma: 243-UA2-1-4 loe: DF-20

Tormb: 243-UA2-15 lob: DH-21 Torme: 243-UA2-16 loc: DO-18 Tornd: 243-UA2-1-7 lod: Do-19

Alarms:

Ai: 0 Ao: 0 Di: 2 Do: 2 Lculoc: $243-Z$

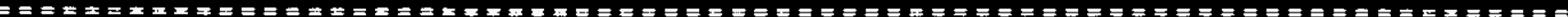
Old_pid: 82732 Now_pid: 82732 Dovnum: MOV-2 Intrango: 120 VAC Stotue: Safoty: 3 Loop: HS-29

Dovtyp: MOTOR VALV Dovtun: F-2028 INLET

Vessel: B680

Dovloc: $243-z$

Commonte:

Torma: 243-UA2-11-4 bo: DI-22

Termb: 243-UA2-11-5 lob: DI-23 Torme: 243-UA2-11-6 loo: DO-20 Tormd: 243-UA2-1F lod: DO-21

Alarms:

Ai: 0 Ao: 0 Di: 2 Do: 2 Leuloc: $243-2$

Micon: WTF_2_2 Micon_no: 5 Bldg: 243-Z

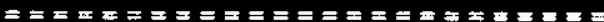

Old_pid: $\mathbf{8 2 7 3 2}$ Now_pid: $\mathbf{8 2 7 3 2}$ Downum: MOV-3

Intrange: 120 VAC Status:

Commente:

Termb: 243-UA2-1-9 lob: DH-25

Alarms:

Ai: O AO: O Di: 2 Do: 2 Leube: $243-2$

Sofoty: 3 Loop: HS-28

Devtype: MOTOA VALV Dovfun: F-202A OUTLET

Vorsel: 8680

Dovloc: $243-2$

Terma: 243-UA2-1-8 loa: D1-24

Can: Wir_t Micon_no: 4 Eldo: 243

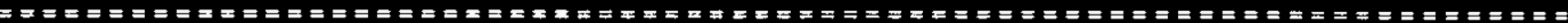
Old_pid: 82732 Now_pid: 82732 Devnum: MOV-4 Devtype: MOTOR VALV Dovfun: F-202B OUTLET Dovloc: $243-2$

Intranoe: 120 VAC Status: Safoty: 3 Loop: HS-29 Loopbun: Voesel: B680

Commente:

Termb: 243-UA2-I1-9 Job: DI-27 Termc: 243-UR2-1l-10 loc: DO-24 Tormd: 243-UA2-II-11 lod: D0-25

Alarms:

Ai: 0 Ao: 0 Di: 2 Do: 2 Lculoc: $243-2$

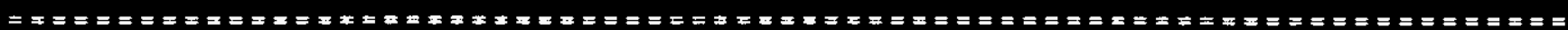
Old_pid: 82733 Now_pid: 82733 Dewnum: MOV-5

Intrana: 120 VAC Status: Safoty: 3 Loop: HS-31

Dovtype: MOTOR VALV Doviun: TRAIN 2 INLET

Dovloc: $243-2$

Vosecel: 8680 
Comments:

Tomb: 243-UA2-13 lob: Dl-31

Alarms:

Ai: 0 Ao:
Torma: 243-UR2-12 lon: Dr-30

Terme: 243-UA2-F14 loc: D0-28 Temnd: 243-UA2-15 bd: DO-29

Micon: WTF_2_1 Micon_no: 4 Bde: $243-2$

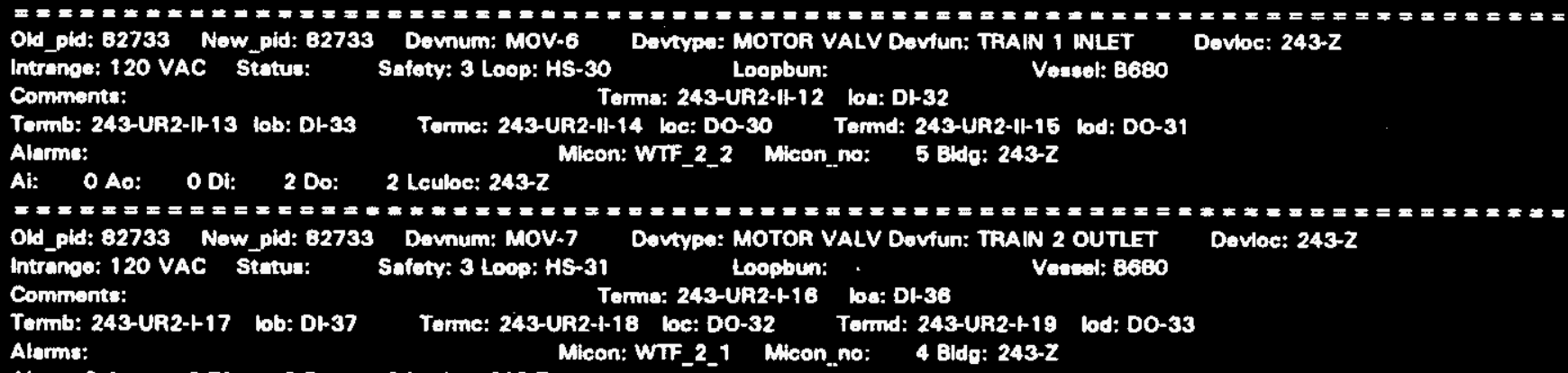

Ai: 0 Ao: 0 Di: 2 Do: 2 Lculoc: $243-2$

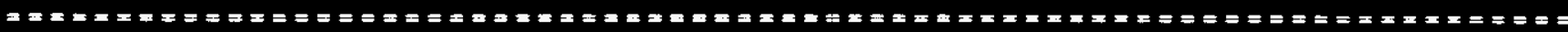
Old pid: $\mathbf{8 2 7 3 3}$ Now pid: $\mathbf{8 2 7 3 3}$ Dovnum: MOV-8 Devtype: MOTOR VALV Dovfun: TRAIN 1 OUTLET Dovloc: $243-2$

Intrenge: 120 VAC Status: Safoty: 3 Loop: HS-30 Vescel: 8680

Comments:

Tormb: 243-UR2-11-17 lob: DH-39

Alarmo:

Ai: 0 Aa: 0 Di: 2 Do: 2 Leube: $243-z$

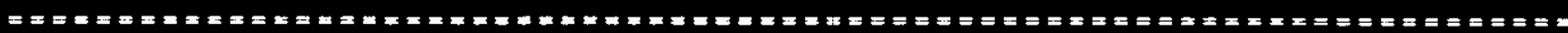
Old_pid: 82733 Now_pld: 82733 Davnum: MOV-9 Davtype: MOTOA VALV Dovfun: OUTLET DNERTER Dovloc: $243-2$

Intrange: 120 VAC Status: Safoty: 3 Loop: HS-32

Torme: 243-UA2-11-18 loa: Dr-38

Torme: 243-UR2-11-18 loc: D0-34 Tarnd: 243-UR2-11-19 lod: D0-35 Micon: WTF_2_2 kicon no: 5 Bldo: $243-Z$

Commonts:

Termb: 243-UA2-1it-10 lob: DF-41

Alarms:

Ai: 0 Ao: 0 Di: 2 Do: 2 Leuloc: $243-2$

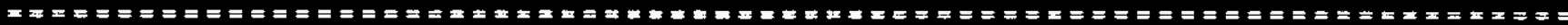
Old pid: 82641 Naw pid: 82641 Devnum: P-1 Intrange: 120 VAC Status: Safoty: 3 Loop: HS-P Davtypa: MOTOR PUMP Doviun: COOLING LOOP PUMP 1 Dovloc: FC-1/2

Comments:

Temb: 45-UR2-1-13 lab: DO-P1-1 Torme: 45-UA2-1-14 loc: DO-P1-2 Tornd: lod:

Alarms:

Ai: 0 Ao: $O$ Di: 1 Do: 2 Lculoc: AM $45 / 6$

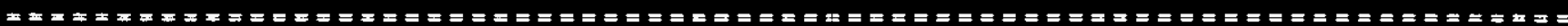
Old pid: 82641 Now_pid: 82641 Dovnum: P-2 Dovtype: MOTOR PUMP Devtun: COOLING LOOP PUMP 2 Davioc: FC-1/2

Intrange: 120 VAC Status: Safoty: 3 Loop: HS-P2 Loopbun: 1-2
Commante:

Torma: 45-UR2-11-12 loa: DH-P2-1

Tormb: 45-UA2-11-13 lab: DO-P2-1 Tormc: 45-UR2-11-14 loc: DO-P2-2 Tormd: Vecest: B680

Alame:

Ai: 0 Ao: 0 Di: 1 Do: 2 Lculoc: AM $45 / 6$

Old pid: 82041

Dovtype: MOTOR PUMP Dovfun: FC-2 SFRAY FUMP

Devloc: FC-1/2

Intrange: 120 VAC Status: Safety: 3 Loop: HS-SP

Tams: 45-UA2-11-5 loa: DL-SP2

Commente:

Tormb: 45-UR2-11-6 lob: DO-SP2A Tormc: 45-UA2-It-7 bc: DO-SP28 Termd: lod:

Alarme:

Micon: RM45_2_2 Micon_no: 12 Bidg: 243-ZB

Ai: OAo: 0 Dl: 1 Do: 2 Lculoc: RM $45 / 6$

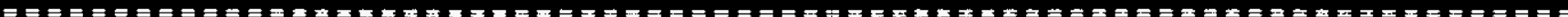
Old_pid: 82642-1 Now_pid: 82642-1 Dovnum: P-101 Davtypa: MOTOR PUMP Davfun: GB LOOP PUMP 1

Intrange: 120 VAC Status: Safoty: 3 Loop: HS-P101 Loophun: $1-3$

Commonts: Terma: 45-UR2-17 ba: Dr-101-1

Tormb: 45-UA2-118 lob: Do-101-1 Tome: 45-UA2-1-19 loc: D0-101-2 Tormd: lod:

Alarms: $\quad$ Micon: AM45_2_1 Micon_no: 11 8idg: $236-2$

Ai: O Ao: 0 Di: 1 Do: 2 Lculoc: AM $45 / 6$

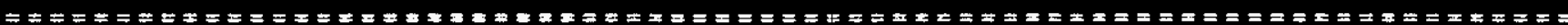
Old_pid: 82642-1 Naw_pid: 82642-1 Devnum: P-102 Dovtype: MOTOR PUMP Devfun: GB LOOP FUMP 2 Devtoc: RM 35

Intrange: 120 VAC Status:

Comments:

Terma: 45-UR2-1F-17 loa: Dr-102-1

Termb: 45-UR2-11-18 lob: Do-102+1 Termc: 45-UR2-11-19 loc: D0-102-2 Termd: lod:

Alams:

Ai: OAo: 0 Di: 1 Do: 2 Leuloc: RM $45 / 6$

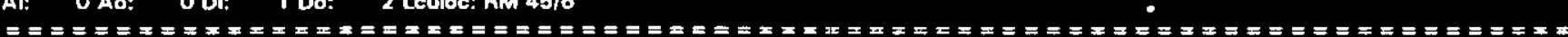

Old_pid: 82642-2 Now_pid: 82642-2 Dovnum: P-106 Dovtypo: MOTOR FUMP Devtun: VP-1 LOOP FUMP Dovloc: RM 35

Intrands: 120 VAC Status: Satoty: 3 Loop: HS-P106 Loopbun: 1-5

Commente:

Terma: 45-UA2-121 loa: DH-106-2

Termb: 45-UR2-1-22 lob: Do-106-1A Ternc: 45-UR2-1-23 loc: Do-106-18 Termd:

Vessal: 8680

lod: 


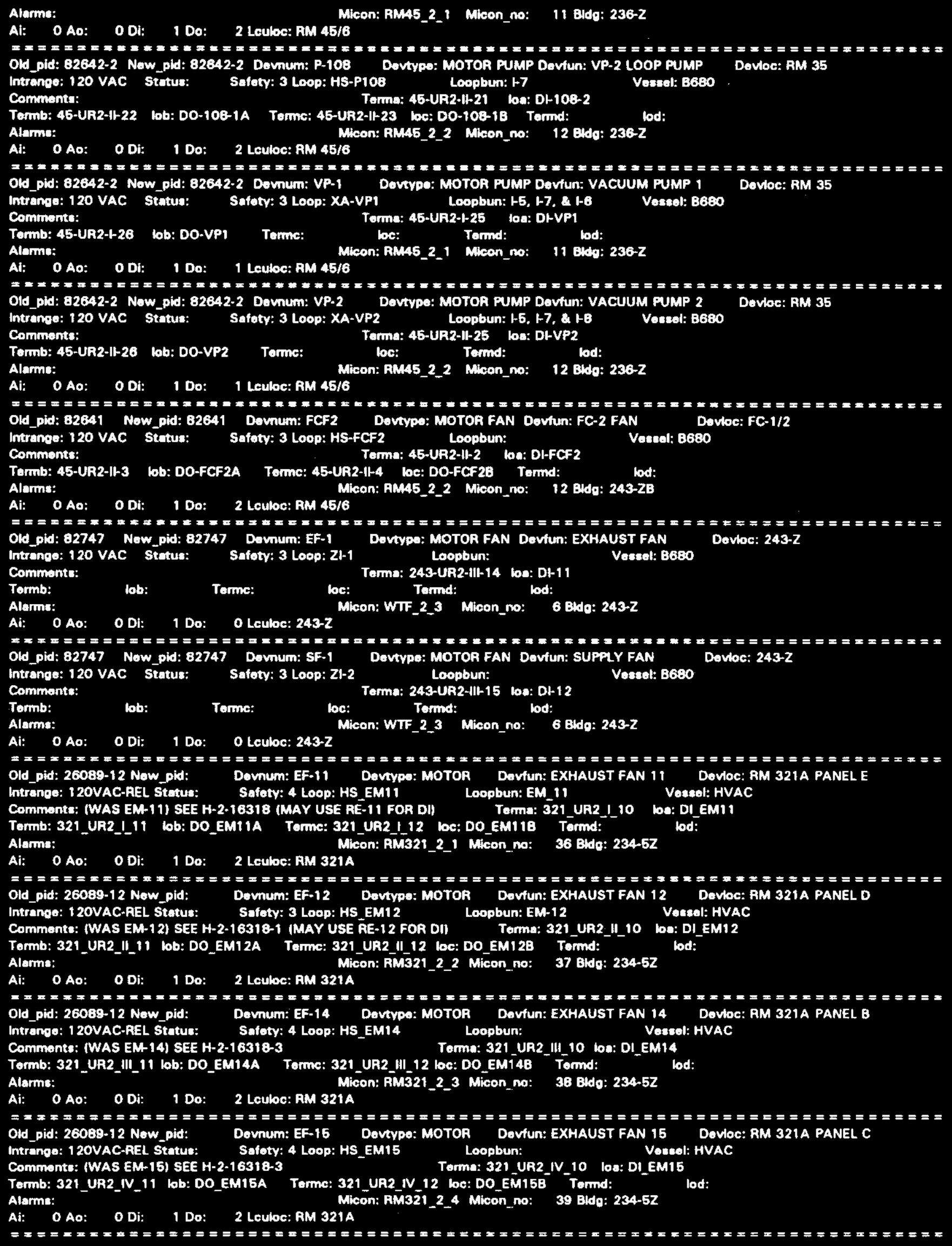


Old_pid: 26089-13 Now_pid: Intrange: 120VAC-AEL Statue: Commante: SEE H-2-16318-3 Tormb: 321 UAs_II_8 lob: Do_sto Alame:

Al: O Ao: O Di: 1 Do:

Devnum: S-10 Devtype: MOTOR Devfun: SUPPLY FAN 10 Satoty: 3 Loop: HS_S10 Loopbun:

Temm: 1 Leulec: AM 321A

\section{Vaseal: HVAC}

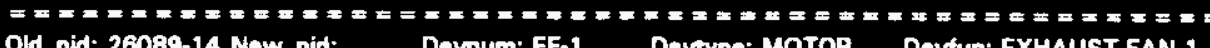

Intrange: 120 AC-REL Stotus: Safoty: 3 Loop: HS EMI Loopbun: Ved

Comments: (WAS EM-1) 125 VDC -- SEE H-2-16328-1 (MAY USE AE-1 FOA DI) Torma: 321_UA2_!7 Ion: DI_EM1

Tormb: 321_UR2__8 lob: DO_EM1_A Tarma: 321_UA2_1_8 loc: DO_EM1_B Tormd:

Alame:

Ai: OAa: 0 Di: 1 Do: 2 Lculoc: PM $321 \mathrm{~A}$

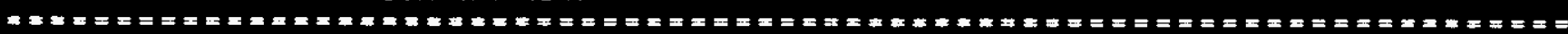

Old_pld: $26009-14$ Now_pid: Downum: EF-2 Dowypo: MOTOR Doviun: EXHAUST FAN 2

Intrange: 120VAC-REL Stotus: Leopbun:

Dovlac: AM 321A PANEL F

Tormb: 321_UR2_II_8 lob: DO_EM2_A Torme: 321_UR2_II_9 loc: DO_EM2_B Tormd:

Alorme:

Ai: O Ao: 0 Di: 1 Do: 2 Leuloc: AM $321 \mathrm{~A}$

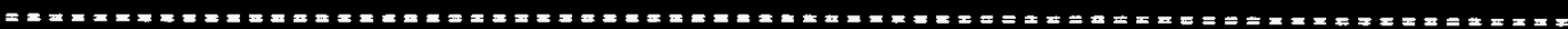

Old_pid: 26089-14 Now_pid: Dovnum: EF-5 Dovtype: MOTOR Dovtun: EXHAUST FAN 5 Devloc: RM 321 A PANEL F

Intrang: 120VAC-REL Stetus: Sofoty: 3 Loop: HS_EM5 Loopbun: Voseol: HVAC

Commonts: (WAS EM-5) 125 VDC -- SEE H-2-16318-1 (MAY USE RE-5 FOR DII Tama: 321_UA2_V_7 ba: DI_EM5

Tormb: 321_UR2_V_8 lob: DO_EM5_A Tarme: 321 UA2_V_8 loc: Do_EM5_B . Termd:

Alarms:

Micon: RM321_2 5 Micon_no: 40 Blds: 234-52

Ai: 0 Ao: 0 Di: 1 Do: 2 Leuloc: RM $321 \mathrm{~A}$

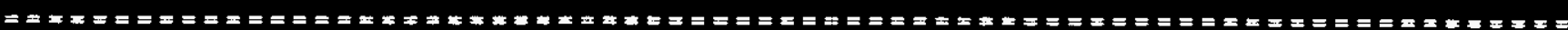

Old_pid: 26009-14 Now_pid: Davum: EF-8 Dovtypo: MOTOR Dovfun: EXHAUST FAN 6

Commonts: (WAS EM-6) 125 VDC -- SEE H-2-16318-1 (MAY USE RE-6 FOR DI) Terma: 321 UR2 VI

Termb: 321_UR2_VI_8 lob: DO_EM6_A Terme: 321_UR2_VI_9 be: DO_EM6_B Tormd:

Voseal: HVAC

Dovioc: AM 321A PANEL F

Ai: 0 Ao: 0 Di: 1 Do: 2 Lculoc: RM $321 \mathrm{~A}$

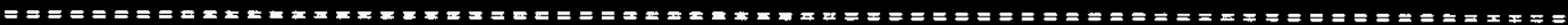
Old_pid: 26089-15 Now_pid: Downum: EF-3 Devtype: MOTOR Daviun: EXHAUST FAN 3

Safoty: 3 Loop: HS EMS

Loopbun: EF3

loa: DI_EMG

Commonts: (WAS EM-3) 125 VDC -- SEE H-2-16318-1 (MAY USE RE-3 FOA DI) Toma: 321_UA2_IH_7 loa: DI_EM3

Tormb: 321_UA2_III_8 lob: DO_EM3_A Tormc: 321_UA2_III_9 be: DO_EM3_B Tormd:

Alarms:

Ai: O Ao: O Di: 1 Do: 2 Lculoc: RM 321A

Micon: AM321_2_3 Micon_no: 38 Eldq: 234-5z

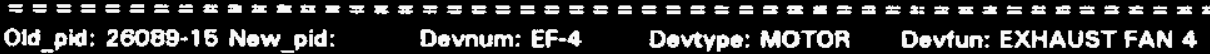

Commants: (WAS EM-4) 125 VDC -. SEE H-2-16318-1 (MAY USE RE-4 FOR DI) Tomn: 321 UA2_IV_7

Termb: 321 UR2 IV 8 lob: DO EM4 A Terme: 321 UR2 IV 9 loc: DO EM4 8 Terms:

Alarms:

Ai: 0 Ao: 0 Di: 1 Do: 2 Leubc: RM $321 \mathrm{~A}$

Micon: AMM21_2_4 Micon_no: 39 Bdds: $234-52$

Dovloc: RM 321A PANEL F

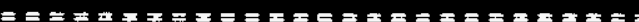

Old_pid: 260eg-15 Now_pid: Devnum: EF.7 Devtype: MOTOR Devin: EXHAUST FAN 7

Intrango: 120VAC-REL Status: Safaty: 3 Loop: HS_EM7 Loopbun:

Commente: (WAS EM-7) 125 VDC .- SEE H-2-16318-1 (MAY USE RE-7 FOR DI) Torma: 321 UA3 I 7 loa: OI EM7

Tormb: 321 UA3_I8 lob: DO_EM7_A Torme: 321_UA3 I_9 loc: DO EM7 B Tormd: lod:

Alame:

Ai: 0 Ao: 0 Di: 1 Do: 2 Lcubc: AM $321 \mathrm{~A}$

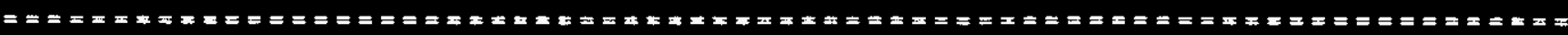
Old_pid: 26089-5 New_pid: Devnum: S-1 Devtype: MOTOR Devfun: SUPPY FAN 1

Intranga: 120VAC-REL Status: Safoty: 3 Loop: HS_SFt Loopbun:

Devloc: RM 321A PANEL F

Comments: 125 VDC PANEL -- SEE H-2-16318-1 (MAY USE RS-1 FOR DI) Torma: 321 UR2 1 1 lo: OI SF1

Termb: 321_UA2_I_2 lob: DO_SF1_A Torme: 321_UR2_13 bo: DO_SF1_B Tormd:

Alonins:

Ai: 0 Ao: 0 Di: 1 Do: 2 Lculoc: AM $321 \mathrm{~A}$

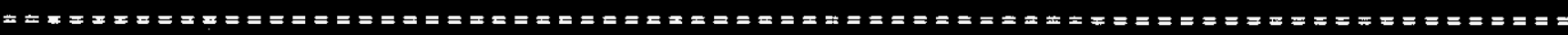
Old pid: 26089-5 Now_pid: Devnum: 5-2 Devtype: MOTOR Devin: SUPPLY FAN 2

Intrange: 120 AC-REL Status: Safoty: 3 Loop: HS_SF2 Loopbun: Vossel: HVAC

Commonts: 125 VDC PANEL SEE H-2-16318-1 (MAY USE AS-2 FOR DI) Torms: 321 UR2 II 1 loa: DI SF2

Tormb: 321_UA2_Il_2 lob: DO_SF2_A Torme: 321_UR2_II3 loc: DO_SF2_B Tormd: lod:

Alarma:

Al: 0 Ao: 0 Di: 1 Do: 2 Leuloc: AM $321 \mathrm{~A}$

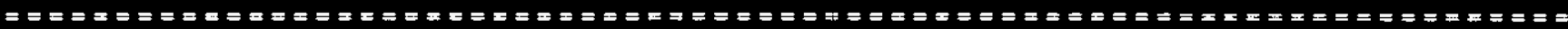

Old_pid: 26089-5 Now_pid: Devnum: SP-1-25A Devtype: MOTOR Deviun: SPRAY FUMP 1

intrango: $120 \mathrm{VAC}-\mathrm{REL}$ Status:

Safoty: 3 Loop: HS_SP1_t Loopbun:

Dovloc: RM 321A PANEL B

Comments: (WAS SP-1)

$$
\text { Torma: 321_UR2_I_4 loa: DI_SP1 }
$$

Vosad: HVAC 
Tarmb: 321_UR2_5 bb: O0_SP1_A Torme: 321 UR2_1_6 be: DO_SP1_B Tormd: bo: Alarms: COMES ON WTH SUPPIY FAN 1 Micon: RM32.1_2_1 Micon_no: 36 Bidg: $234-62$ Ai: O Ao: O Di: 1 Do: 2 Leuloc: AM 321A

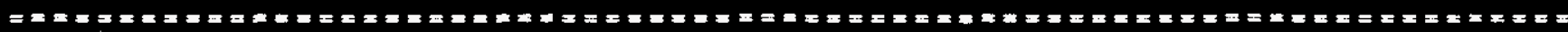
Old_pid: 26089-6 Now_pid: Dovnum: sp-2-25A Dovtype: MOTOR Dovtun: SPRAY PUMP 2 Dovioc: RM 321A PANEL C Intrengo: 120VAC-AEL Status: Safoty: 3 Loop: HS_SP2 $1 \quad$ Loopbun: Vocsol: HVAC Commants: (WAS SP-2) Tormb: 321_UA2_Il_5 lob: DO_SP2_A Torme: 321_UA2_"l_6 be: DO_SP2_B Tormd:

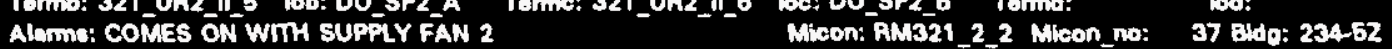

Ai: O Ao: O Di: 1 Do: 2 Leube: AM 321A

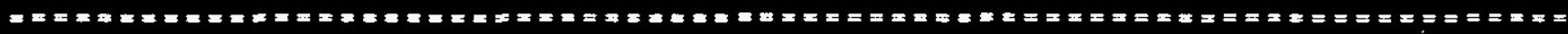
Old_pid: 26089-6 Now pid: Dovnum: S-3 Dovtype: MOTOR Deviun: SUPPLY FAN 3 Devloc: AM 321A PANEL F

Intronge: 120VAC-AEL Stentus: Safoty: 3 Loop: HS SF3 Loophun: Voscol: HVAC

Commente: 125 VDC PANEL - SEE H-2-16319-1 (MAY USE RS-3 FOR DI) Torma: 321 UR2_II__ Va: DI_SF3

Tormb: 321 UR2_II_2 bb: DO_SF3_A Torme: 321_UA2_111_3 be: DO_SF3_B Tormd:

Alesms:

At: O Ao: O Di: 1 Do: 2 Leube: AM 321A

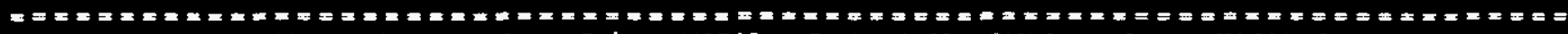
Old pid: 26089-6 Now pid: Dovnum: S-4 Devitype: MOTOR Doviun: SUPPLY FAN 4 Dovbe: RM 321A PANEL F

Intrango: 120VAC-AEL Stetus: Safoty: 3 Loop: HS_SF4 Loopbun: Voncel: HVAC

Comments: 125 VDC PANEL -- SEE H-2.1631B-1 (MAY USE RS-4 FOA DI Torma: 321 UR2 IV 1 los: DI SF4

Tormb: 321_UA2_IV_2 bb: DO_SF4_A Tornc: 321_UR2_IV_3 bo: DO_SF4_B Tormd: - bod:

Alarme:

Al: O Ao: O Di: 1 Do: 2 Leuloc: RM 321A

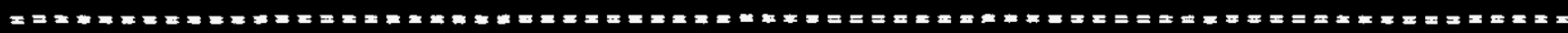
Old_pid: 26089-8 Now_pld: Devnum: SP-3-25A Devtype: MOTOR Dovfun: SPRAY PUMP 3 Dovloc: AM 321A PANEL D

Intronge: 120VAC-REL Stetur: Safoty: 3 Loop: HS_SP3_1 Loopbun: Vessel: HVAC

Commente: (WAS SP-3)

Tormb: 321_UR2_III_5 lob: DO_SP3_A Torme: 321_UR2_HI_6 loc: DO_SP3_B Torind:

Alarms: COMES ON WITH SUPP̈LY FAN 3 Micon: RM321 2 3 Micon_no: 38 Bkdg: $234-52$

Ai: 0 Ao: 0 Di: 1 Do: 2 Leuloc: AM $321 \mathrm{~A}$

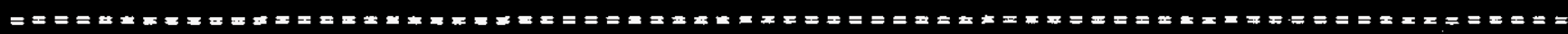
OW pid: 26089-6 Now_pid: Dovnum: SP-4-25A Dovtypo: MOTOA Dovtun: SPAAY PUMP 4 Dovioc: RM 321A PANEL E

Intrange: 120VAC-REL Stotue: Sototy: 3 Loop: HS_SP4_1 1 Loopbun:
Comments: (WAS SP-4)

Tormb: 321 UA2_IV_5 lob: DO_SP4_A Tormk: 321_UA2_IV_6 bo: DO_SP4_B Tormd: lod:

Alarms: COMES ON WITH SUPPLY FAN 4 Micon: RM321_2 4 Micon_no: 39 Bidg: $234-52$

Ai: OAO: O Di: 1 Do: 2 Leuloc: RM 321A

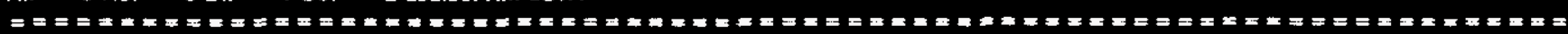

Old_pid: 26089-7 Now_pid: Dewnum: S-5 Dovtypo: MOTOA Dovfun: SUPPLY FAN 5

intrange: 120VDC-AEL Status: SAfety: 3 Loop: HS_SF5 Loopbun: Veasel: HVAC

Commonts: 125 VDC PANEL -- SEE H-2-16218-1 (MAY USE RS-5 FOA DI Torma: 321_UR2_V_1 loa: DI_SF5

Tormb: 321 UR2_V_2 lob: Do_SF5_A Tarmc: 321 UR2_V_3 loc: Do_sF5_B Tormd:
Alarms:

Ai: O AQ: O Di: 1 Do: 2 Leuloc: AM 321A

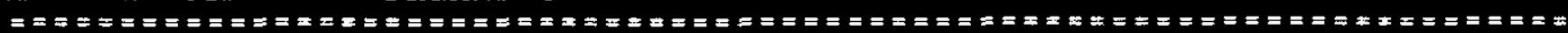

Old_pid: $26089-7$ Now_pid: Devnum: S-6 Devypa: MOTOA Devfun: SUPPLY FAN 6

Introno: 120VAC-REL Status: Satoty: 3 Loop: HS SF6 Loopbun:

Commonts: 125 VDC PANEL +- SEE H-2-18318-1 IMAY USE R5-6 FOA Dn Tomm: 321 UA2_VI_1 loa: DISSF6

Termb: 321_UA2_VI_2 lob: DO_SF6_A Tormc: 321 UR2_VI_3 loc: DO_SF6_B Termit: - lod:

Alarms: $\quad$ Micon: ĀM321_2_6 Micon_no: 41 Bidg: 234-52

Ai: 0 Ao: 0 Di: 1 Do: 2 Lculoc: RM $321 \mathrm{~A}$

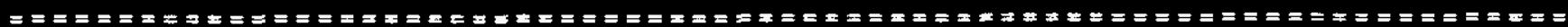

Old_pid: 26089-7 Now_pid: Dovnum: SP-5-25A Dovtype: MOTOR Devfun: SFRAY PUMP 5

Intranga: 120VAC-AEL Status: Satoty: 3 Loop: HS_SP5_1 Loopbun:

Commonts: (WAS SP.5)
Tormb: 321 UR2 V 5 lob: DO SP5 A Tormc: 321 UR2 V 6 bo: Do_SF5 B Termd:

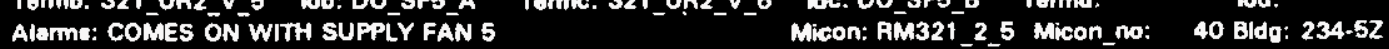

Ai: 0 Ao: 0 Di: 1 Do: 2 Leuloc: RM 321 A

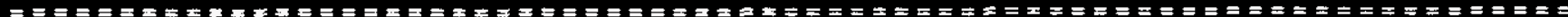
Old_pid: 26089-7 New_pid: Dovmum: SP.6-25A Dovypo: MOTOA Dovfun: SPAAY PUMP 6 Intranos: 120 AC-FEL Status: Safoty: 3 Loop: HS_SP6_ 1 Loopbun:

Commente: (WAS SP-6) Terma: 321 UR2_V! 4 lon: DI_SP6

Tormb: 321_UA2_VI_5 lob: DO_SP6_A Torme: 321 UA2_V1_6 loc: DO_SP6_B Tornd:

Vosed: HVAC

Dovloc: RM 321A PANEL B

Alarms: COMES ON WITH SUPPLY FAN 6

Ai: $O$ AQ: $O$ Di: 1 Do: 2 Lculoc: AM 321 A

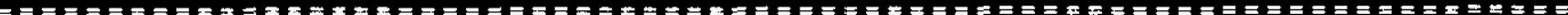
Old_pid: 26099-8 Now_pid: Dovnum: S-7 Dovtypo: MOTOR Devfun: SUPPLY FAN 7

Intrango: 120VAC-REL Status: Safoty: 3 Loop: HS_SF7 Loopbun:

Comments: 125 VDC PANEL -- SEE H-2-18318-1 (MAY USE RS-7 FOR DI) Torma: 321 UR3!1 loo: DI_SF7

Termb: 321_UR3_L_2 lob: DO_SF7_A Tamc: 321 UA3_1_3 loc: DO_SF7_B Tormd: lod:

Alarms: $\quad$ Micon: FM321_3_t Micon_no: 42 Bidg: $234-52$

Ai: $O$ Ao: $O$ Di: 1 Do: 2 Lculoc: $\mathrm{AM} 321 \mathrm{~A}$ 


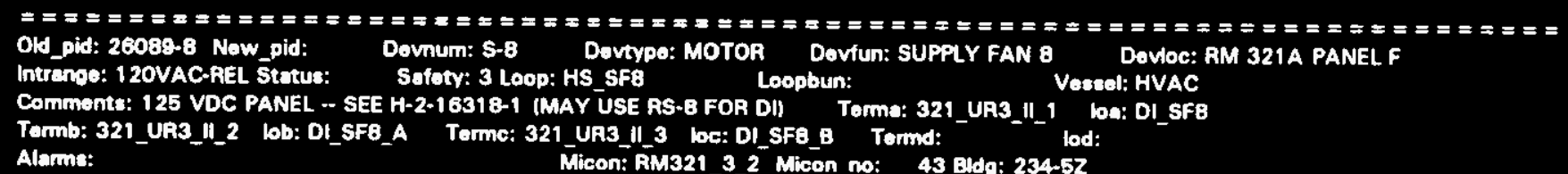
Alarme: Ai: 0 AO: 0 Di: 1 Do: 2 Leuloc: RM 321A

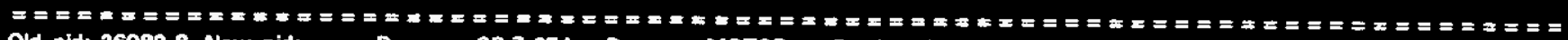
Old_pid: $26089-8$ Now_pid: Davnum: SP-7-25A Dovtypo: MOTOR Dovfun: SPRAY PUMP 7 Devloc: RM 321A PANEL D

Intrange: 120VAC-REL Status: Safoty: 3 Loop: HS_SP7_1 Loopbun: HVAC

Commante: (WAS SP-7) Torma: 321_UA3_I_4 ba: DI_SP7

Tomb: 321_UA3_15 bb: DO_SP7_A Terms: 321 UA3 I_6 loc: DO_SP7_B Tarmd:

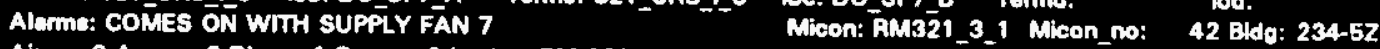

Ai: 0 Ao: $O$ Di: 1 Do: 2 Lculoc: PM 321 A

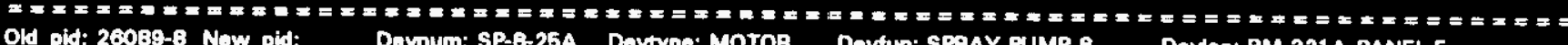
Old_pid: 26089-8 Now pid: Dovnum: SP-8-25A Dovtypo: MOTOR Dovfun: SPAY PUMP 8 Dovioc: RM 321A PANEL E

Intrande: 120VAC-REL Status: Safoty: 3 Loop: HS_SP7_1 Loopbun: Voseal: HVAC

Comments: (WAS SP-8)

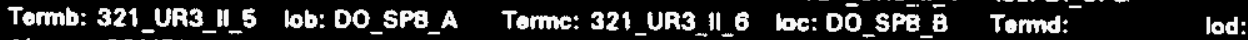

Alams: COMES ON WITH SUPPLY FAN $8 \quad$ Micon: RM321_3_2 Micon_no: 43 Bldg: 234-52

Ai: 0 Ao: 0 Di: 1 Do: 2 Leuloc: AM $321 \mathrm{~A}$

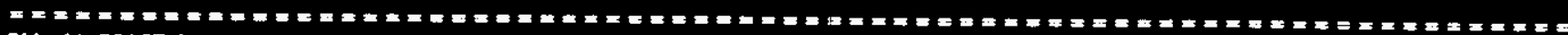

Old_pid: E0167-2 Now_pid: Dovmum: EF-3 Dovtypo: MOTOR Dovin: MEN'S ROOM EXHAUST Dovloc: RM EO2 O3703

Intrange: 120 VAC Status: Sofoty: 3 Loop: Loopbun: EF3 [SF1/2) Voseal: ZB

Commonte: USED TO SHUT DOWN FAN Torma: ZB_UA2_III_2 loa: DO_EF_3

$\begin{array}{lll}\text { Tarmb: lob: Terme: loc: } & \text { Tormd: } \\ \text { Alarms: } & & \text { Micon: 28_2_3 Micon_no: 20 Bddo: 2736-ZB }\end{array}$

Ai: 0 Ao: O Di: 0 Do: 1 Lculoc: RM 602

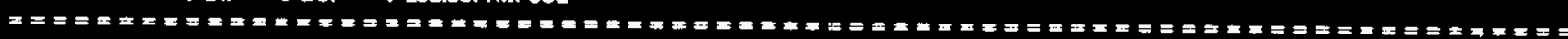

Old_pid: 80167-2 Now_pid: Damum: SF-1 Dovtyo: MOTOA Devtun: SUPPLY FAN 1 Devioc: AM 602 SEE COMMENTS

Intrange: 120 VAC Status: Safoty: 3 Loop: HS_SF_1 Loopbun: SF1A, SF1B Vessel: ZB

Commente: READY - 12600, RUN - 12601. START - 0250̄0 Torma: ZB_UR2_J_1 loa: DI_SF_IA

Tormb: ZB_UR2_I_2 lob: DI_SF_1B Tormc: ZB_UA2_I_3 loc: DO_SF_1 Termd:

Alarms: $\quad$ Micon: ZB_2_1 Micon_no: 18 Brdo: $2736-2 B$

Ai: 0 Ao: 0 Di: 2 Do: 1 Lculoc: RM 602

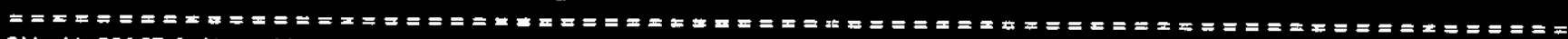
Old_pid: 80167-2 Now_pid: Dovnum: SF-2 Devtype: MOTOR Dovfun: SUPPLY FAN 2 Dovloc: RM 6O2 SEE COMMENTS

Intrange: 120 VAC Status: Safoty: 3 Loop: HS_SF_2 Loopbun: SF2A. SF2B

Comments: READY-12602, RUN - 12603, START - 02501 ${ }^{-2}$ Torma: Z8_UA2_I_1 loa: DI_SF_2A

Termb: Z8_UR2_I_2 bb: DI_SF_28 Terme: ZB_UR2_II_3 loc: Do_SF_2 Tormd: lod:

Alams:

Ai: O Ao: O Di: 2 Do: 1 Leuloc: RM 602

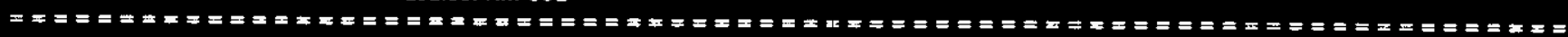
Old_pid: 00167-4 Now_pid: Dovmum: EF-1 Dovtypa: MOTOR Dovfun: EXHAUST FAN 1 Dovloc: RM 602 SEE COMMENTS

Intrange: 120 VAC Stotus: Safoty: 3 Loop: HS_EF_1 Loopbun: EF1A/B Veseel: ZB

Comments: READY - 12704, RUN - 12705, START - 02510 Torma: ZB_UA2_1_4 loa: OI_EF_1A

Termb: ZB_UR2_I5 lob: DI_EF_18 Torme: ZB_UR2_1_6 bo: DO_EF_1 Tormd:
Alarm:

Ai: 0 Ao: 0 Di: 2 Do: 1 Lculoc: RM 602

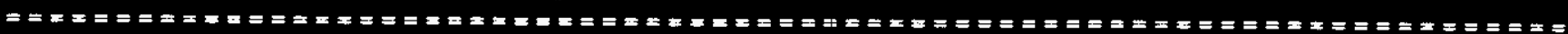
Old_pid: B0167-4 Now_pid: Dovnum: EF-2 Dovypo: MOTOR Dovtun: EXHAUST FAN 2 Dovloc: RM 602 SEE COMMENTS

Intranos: 120 VAC Status: Safoty: 3 Loop: HS_EF_2 Loopbun: EF2A/B Vescel: ZB

Commonte: READY - 12706, RUN - 12707, START - 02511 Torma: ZB_UR2_"I4 los: DI_EF_2A

Termb: ZB_UA2_It_5 lob: DI_EF_2B Tormc: ZB_UR2_II_6 loc: DO_EF_2 Tormd:

Alarms: $\quad$ Micon: 28_2_2 Micon_no: 19 Bddg: $2736-28$

Ai: 0 Ao: 0 Di: 2 Do: 1 Lculoc: AM 602

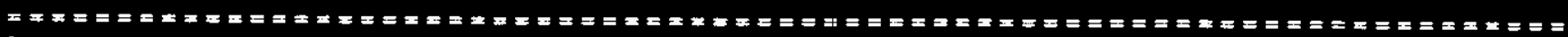
Old_pid: 80187-4 Now_pid: Dovnum: RF-1 Dovtypo: MOTOR Dovtun: RETURN FAN 1 Dovtoc: RM 602 SEE COMMENTS

Intrange: 120 VAC Status: Safoty: 3 Loop: HS_RF_1 Loopbun: RF1A/B Veseol: ZB

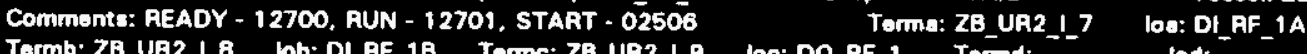

Tormb: ZB_UA2_I_8 lob: DI_AF_1B Tormc: ZB_UR2_I_9 loc: DO_AF_1 Tormd:

Alarms: $\quad$ Micon: ZB_2_1 Micon_no: 18 Bidg: $2736-28$

Ai: 0 Ao: $O$ Di: 2 Do: 1 Lculoc: RM 602

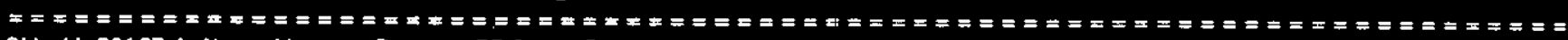
Old_pid: 80167-4 Now_pid: Dovmum: RF-2 Dovtypo: MOTOR Deviun: RETURN FAN 2 Dovoc: RM 602 SEE COMMENTS

Intrange: 120 VAC Status: Safoty: 3 Loop: HS_RF_2 Loopbun: RF2A/B Voesel: ZB

Comments: READY - 12702, RUN - 12703, START - 02507 Torma: ZB_UA2_II_7 loa: DI_RF_2A

Tormb: Z8_UR2_II_8 lob: DI_RF_28 Tormc: ZB_UR2_II_9 loc: DO_RF_2 Tormd:

Alarms:

Ai: $O$ Ao: 0 Di: 2 Do: 1 Lculoc: RM 602

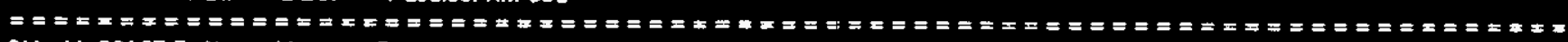

Old_pld: 80167-5 Now_pid: Dovnum: AC-2736-ZA Devtype: MOTOR Devfun: 2736-2A COMFRESSOA Dovloc: RM 602 03700

Intrang: 120 VAC Stotus: Safoty: 3 Loop: HS_ZA_AC Loopbun: Vosel: ZB 
Comments: SEE H-2-E0159-2
$\begin{aligned} & \text { Temb: } \\ & \text { Alarms: }\end{aligned}$

Ai: 0 Ao: 0 Di: 0 Do: 1 Leube: AM e02

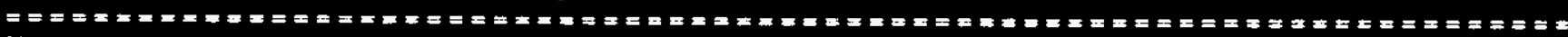
Old_pid: 80167.5 Now_pid: Downum: EF-1.1 Dovypa: MOTOR Deviun: EXHAUST FAN 1-1 Dovoc: RM 602 SEE COMMENTS Intrange: 120 VAC Stetus: Safoty: 3 Loop: HS_1_1 Loopbun: 1-1 Vostel: ZB Commente: READY-12710, TD-13512124VDC), START-0̄2517 - SEE H-2-80159-3 Tama: ZB_UA2_I10 ba: DI_1_1A Tarmb: 2B_UR2_N_1 bb: DI_1_10 Tormc: 28_UA2_111 bc: Do_1_1 Tormd: Alams:

Al: 0 Ao: 0 Di: 2 Do: 1 Lculoc: AM 602

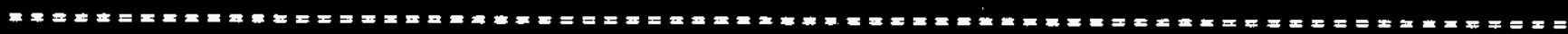
Old_pld: 80167-5 Now_pid: Dovnum: EF-1-2 Dovtypo: MOTOR Dovfun: EXHAUST FAN 1-2 Dovioc: AM 602 SEE COMMENTS Intrango: 120 VAC Siatus: Safoty: 3 Loop: HS-1-2 Loopbun: 1-2A/B Vosed: ZB Commonts: A-12711, TD-13513(24VDC,HS-13514424VDC),S-02516-SEE Bo158-3 Torma: 28_UA2_I_10 ba: DI_1_2A

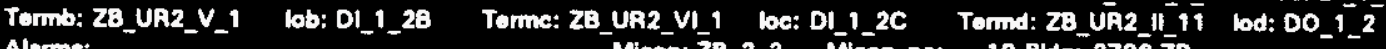
Alarms:

Al: 0 Ao: 0 Di: 3 Da: 1 Lcube: AM 602

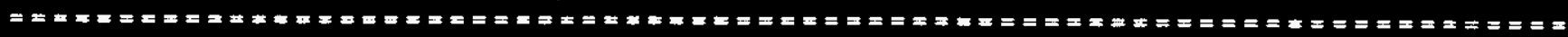
Old_pid: 80167.5 Now_pid: Dovnum: SF-5 Dovtypa: MOTOR Doviun: SUPFI FAN 6 Intrange: 120 VAC Status: Sofoty: 3 Loop: HS_SF_5 Loopbun: SF5A/B Veasel: 28 Commente: READY-12610, RUN-12811. START-02504 -- SEE H-2-80159-1 Toma: ZB_UR2_L12 los: DI_SF_5A Tormb: ZB_UR2_L13 lob: DI_SF_5B Torme: ZB_UR2_1_14 loc: DO_SF_5 Tormd: lod: Alarins:

Ai: 0 Aa: 0 Di: 2 Do: 1 Lculoc: AM 602

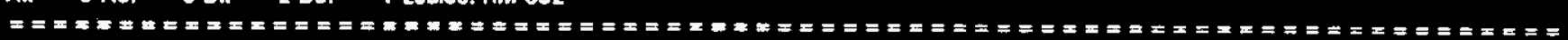
Od_pid: $80167-6$ Now_pid: Davnum: SF-6 Dovtype: MOTOR DeVIUn: SUPPLY FAN 6 Devloc: RM 602 SEE COMMENTS

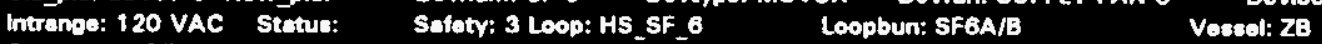

Commente: READY-1281 2, RUN-12613, START-02505 - SEE H-2-80158-1 Torma: ZB_UR2_I_12 loa: D1_SF_6A

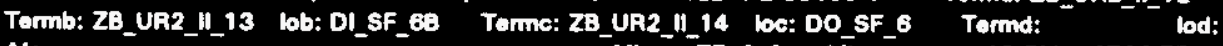
Alerms:

Ai: 0 AO: 0 Di: 2 Do: 1 Louloc: RM 602

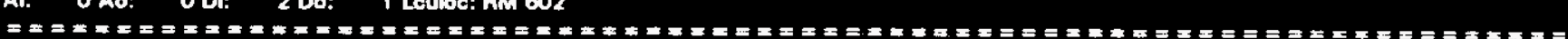
Old_pid: B0167-6 Now_pid: Dewnum: SF-3 Dovtypa: MOTOR Dovfun: SUPPLY FAN 3 Devoc: RM 602 SEE COMMENTS Intrange: 120 VAC Status: Safoty: 3 Loop: HS_SF_3 Loopbun: SF3A/B Vosed: ZB

Comments: REAOY.12604, RUN-12605. START-02502 SEE H-2-80159-1 Torma: ZB_UR2__15 ba: DI_SF_3A

Termb: 2B_UR2__16 bb: DI_SF_3B Tormc: ZB_UR2_117 loc: DO_SF_3 Tornd:

Alarms: $\quad$ Micon: ZB_2_1 Micon_no: 18 Bddg: $2736-28$

Ai: 0 Ao: O Dl: 2 Do: 1 Lculac: AM 602

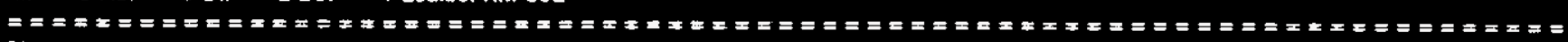
Old_pid: 80t67-6 Now_pid: Dovnum: SF-4 Dovtype: MOTOR Dovfun: SUPPLY FAN 4 Dovloc: RM 602 SEE COMMENTS

intrange: 120 VAC Status: Safaty: 3 Loop: HS_SF_4 Loopbun: SF4A/B Vesel: ZB

Commants: AEADY-12606, RUN-12607, START-02503 SEEH-2-00159-1 Torma: ZB_UA2_It_15 loa: DI_SF_4A

Tormb: ZB_UR2_II_18 bb: DI_SF_48 Tomc: Z8_UR2_II_17 bo: DO_SF_4 Tormd:

Alarms: 19 Bidd: $2736-Z 3$

Ai: 0 Ao: 0 DI: 2 Do: 1 Leuloc: AM 602

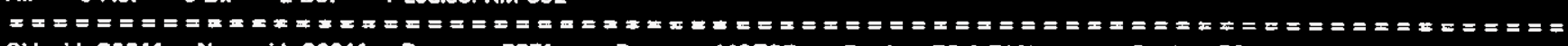
Old_pid: 82841 Now_pid: 82641 Devnum: FCF1 Dovtype: MOTOA Dovtun: FC-1 FAN Devbe: FC-1/2

Intrango: 120 VAC Stotus: Safoty: 3 Loop: HS-FCF1 Loopbun: Voscel: B680

Comments:
Tormb: $45-$ UA2-1-3 lob: DO-FCFIA Terme: 45-UR2-1-4 loc: Do-FCF18 Termd:

Alams: $\quad$ Miean: RM45_2_1 Micon_no: 11 Bido: $243-28$

Ai: 0 Ao: 0 Di: 1 Do: 2 Lculoc: RM $45 / 6$

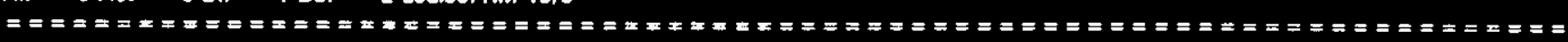
Old_pid: 82641 Now_pid: 82641 Dovnum: SP1 Dovtype: MOTOR Doviun: FC-1 SPAAY PUMP Devioc: FC-1/2

Intrange: 120 VAC Status: Safoty: 3 Loop: HS-SPI Loopbun: Veasel: B680

Commanto: LCU LOCATION EMHER 243-Z OA AM 45/6 Toma: 45-UR2-1-5 loa: DH-SP1

Termb: 45-UR2-16 lob: D0-SP1A Tarnc: 45-UR2-1-7 loc: DO-SP1B Tornd:

Alarms:

Ai: 0 Aa: 0 Di: 1 Do: 2 Leuloc: RM $45 / 6$

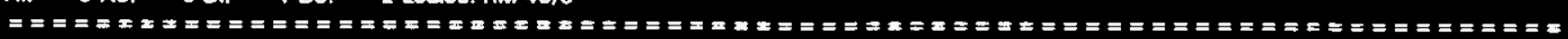
Old_pid: 82732 Now_pid: 82732 Devnum: P-101A Dovtype: MoTOR Dovfun: T-101 SUMP PUMP A Devioc: $243-2 A$

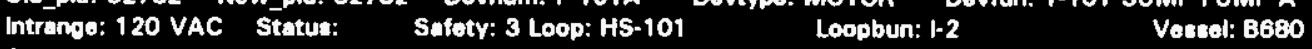

Commente:

Tomb: 243-UR2-1-2 lob: 00-1 Terme: 243-UA2-1 3 torma: 243-UA2-1-1 b1-1

Alarms: OFF ON LAL-101; ON ON LAH-101 OR (P-1018 OFF 2 HS-101 ON B) Micon: WTF_2_1 Micon_no: 4 Bidg: 243-ZA

Ai: 0 Aa: 0 Di: 1 Do: 2 Leuloc: $243-Z$

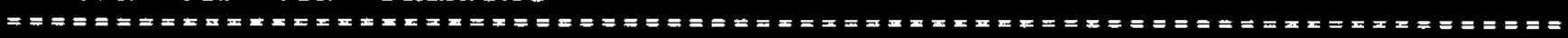

Old_pid: 82732 Now_pid: 82732 Dovnum: P-1018 Davtype: MOTOR Devfun: T-101 SUMP FUMP B Devloc: $243-2 A$

Intrango: 120 VAC Status: Safoty: 3 Loop: HS-101B Loopbun: 1-3 Veasel: B680

Commants:

Tomb: 243-UR2-11-2 lob: DO-3 Tame: 243-UR2-11-3 loc: DO-4 Termd: lod:

Alams: OFF ON LAL-101; ON ON LAH-101 OA (P-101A OFF 8 HS-101 ON A) Micon: WTF_2_2 Micon_no: 5 Bldg: $243-2 A$ 
Ai: OAo: O Dl: 1 Do: 2 Leuloo: $243-2$

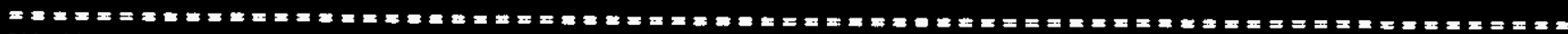
Old_pid: $96418-3$ Naw_pid: Dovnum: PMP-1 Dovtrpe: MOTOR Devfun: VACUUM PUMP 1 Intrange: 120 VAC Status: Safoty: 4 Loop: HS_VP1 Loopbun: VP1 Vessel: 26VAC Comments: REMOVE FROM RELAYS K-2,3,5,86 SEE H-2-28087-2,28737-1,028738 Torma: 321_UR3_IV_6 los: DI_VPI

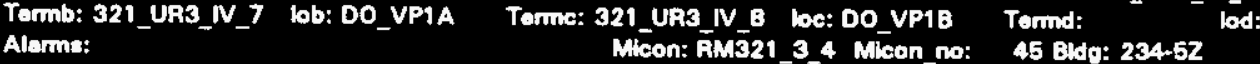

Ai: 0 Ao: 0 Di: 1 Do: 2 Leubo: RM 321 A

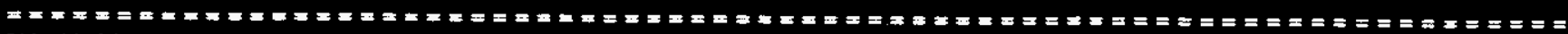
Old_pid: 96418-3 Now_pld: Dovnum: FVP-2 Dovtype: MOTOR Devin: VACUUM PUMP 22 Dovloc: RM 321 26VAC Intronge: 120 VAC Statua: Safoty: 4 Loop: HS_VP2 Loopbun: VP2 Vossel: 26VAC Commants: REMOVE FROM AELAYS K-2,3,6,46 SEE H-2-28087-2,28737-1,820038 Torma: 321_UA3_V_6 loa: DI_VP2 Termb: 321 UA3_V_7 bb: DO_VP2A Terme: 321_UR3_V_8 loc: Do_VP2B Tormd: - - iod: Alarma:

Al: 0 Ao: 0 Ol: 1 Do: 2 Leulee: AM $321 \mathrm{~A}$

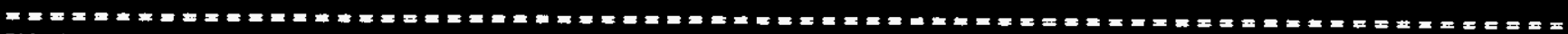
Old_pid: 96418-5 Now_pid: Dovnum: SWP-1 Dovtypo: MOTOR Dovfun: SEAL WATER PUMP Devloc: RM 321A 26VAC Imtrango: 120 VAC Statua: Safoty: 4 Loop: HS_SWP1 Loopbun: SWP1, VP1, VP2 Commonts: REMOVE FROM RELAYS K-1,2,86 SEE H-2-28737-1 28738 Terma: 321_UR3_III_10 los: DI_SWP1 Termb: 321 UA3_III_11 lob: DO_SWP1A Terme: 321 UA3_III_12 be: Do_sWP18 Temd: Alarms:

Ai: OAo: 0 Di: 1 Do: 2 Lculoc: AM $321 \mathrm{~A}$

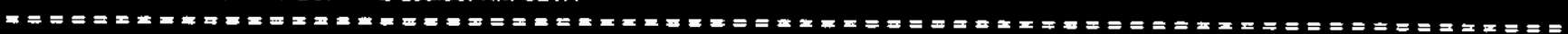
Old_pid: 96418-6 New_pid: Devnum: GCP-1 Devype: MOTOR Devfun: PAOCESS WATEA FUMP 1 Devloc: RM 321A 26VAC Intrango: 120 VAC Status: Safoty: 4 Loop: HS_GCP1 Loopbun: GCP1 Vossel: 26VAC Commonti: AEMOVE FROM AELAY K-1 SEE H-2-28737-2 298738 Toma: 321 UA3_IV_9 loa: DI_GCP1 Tormb: 321_UA3_IV_10 lob: DO_GCP1A Tormc: 321 UA3_N_11 loc: Do_GCP1B Tormd: - lod: Alarma:

Al: OAd: O Di: 1 Do: 2 Leube: RM 321A

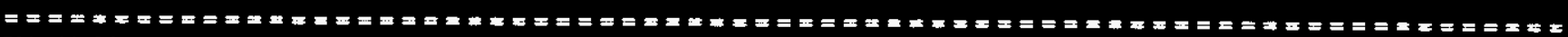
Old pid: 96410-6 Now_pld: Devnum: GCP-2 Dovtype: MOTOR Dovfun: PROCESS WATER PUMP 2 Devloc: RM 321 A 26 AC

Intrande: 120 VAC Status: Safoty: 4 Loop: HS_GCP2

Commonts: REMOVE FROM RELAY K-1 SEE H-2-28737-2 \& 28738 Loopbun: GCP2

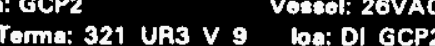

Tormb: 321_UA3_V_10 bb: DO_GCP2A Termc: 321 UA3_V_11 loc: DO_GCP2B Termd: Alarms: Ai: 0 Ao: 0 Di: 1 Do: 2 leuloc: RM 321 A Micon: AM321_3_5 Micon_no: 46 Eldg: 234-5z

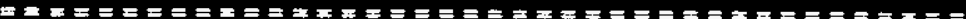
Intrange: 120 VAC Stetus: Sofoty: 3 Loop: HS-20

Commente: DO IS START ONLY -- NO STOP

Termb: 243-UR2-111-6 lob: DO-9 Tarme: Alarme: Ai: 0 Ao: 0 Di: 1 Do: 1 leuloc: $243-Z$

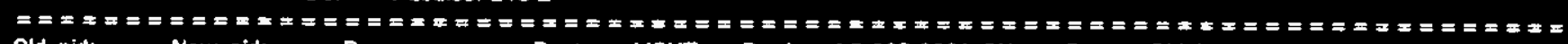
Old_pid: Now_pid: Dovnum: Dovtype: LIGHT Dovfun: AC-23P-3001 ON Dovloc: AM 321A PANEL L

Intrange: $120 \mathrm{VAC}^{-}$Status: Safoty: 3 Loop: Lopbun: Vesel: C171

Comments: $\quad$ Torma: 321_UR2_1_22 ba:

Tormb: lob: Terme: loc: Torind:

Alarms: $\quad$ Micon: RM321_2_1 Micon_no: 36 Bida: $234-52$

Ai: O Ao: 0 Di: 1 Do: 0 Lculoc: AM 321 A

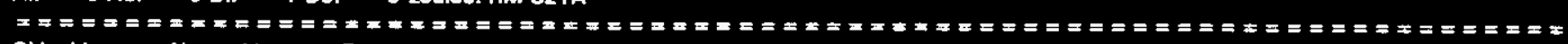
Old_pid: Now_pid: Devnum: Davtypo: LIGHT Devfun: AC-23P-3002 ON Dovloc: RM 321A PANEL L Intrange: 120 VAC Status: Safaty: 3 Loop:
Commente:

Comments:

Termb:

Alarms:

lob: Tormc:

Micon: AM321_2_2 Micon_no: 37 Bldd: 234.52

Leuloc: RM 321A

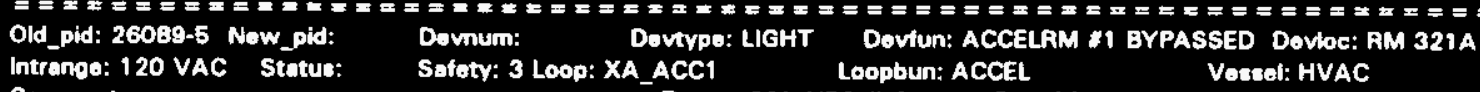

Comments:

Tormb:

Alarms:

Ai: O Ao: O Di: 1 Do: 0 Lculoc: RM $321 \mathrm{~A}$

Torma: 321 UA3 II_9 loa: DI_ACC1

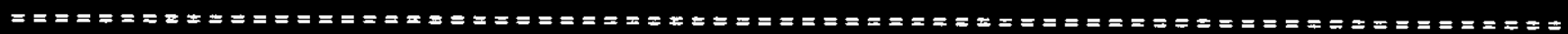
Old_pid: $26089-5$ Now_pid: Downum: Dovtypo: LIGHT Dovfun; ACCELRM \#2 BYPASSED Dovloc: RM 321 A

Intrange: 120 VAC Status: Safoty: 3 Loop: XA_ACC2 Loopbun: ACCEL Vessel: HVAC Comments:

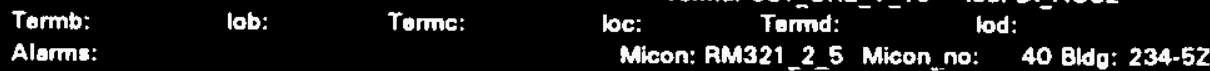

Ai: O Ao: O Dr: 1 Do: O teuloc: RM 321A

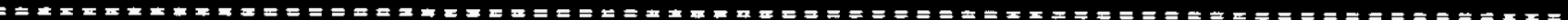




\section{WHC-SD-610-PSAR-002 REV 1}

Ord_pid: 26009-5 Now_pid: Intrange: 120 VAC Strtus: Commente:

Tormb: bb:

Alarima:

Ai: 0

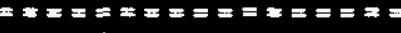

Old_pid: 26089-5 Now_pid:

intranga: 120 VAC status:

Comments:

Devnum:

Devtype: LISHT

Daviun: POW Loopbun: ACCEL

Satoty: 3 Loop: XI_ACCS

A2_V_11 be: DI_ACC6

Torme:

rec:

Micon: RM321 25 Micon no: lod:

Tormb: lob: Torme: loc: Micon: AM321_3_1 Micon_no: 42 Bide: 234-62
Alarme:

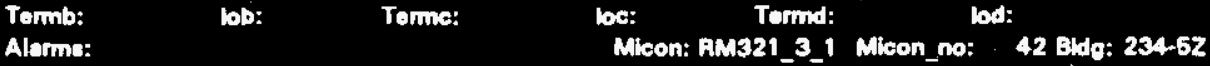

Al: 0 Aa: O Di: 1 Da: 0 Leuloe: RM 321A

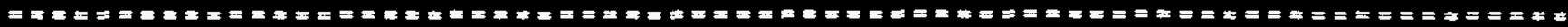

Old_pid: 26089-5 Now_pid:

Dovoum:

Devtype: LIOHT

Dovtun: SESSM

Vescol: HVAC

Commants:

Tormb:

Sofoty: 3 Loop: XI_ACCI

Loopbun: ACCEL

Dovloc: RM 321A

Qosol: HVAC

Vossol: HVAC

Micon: AM321_26 Micon no: 41 Bldg: 234.52

Ai: 0 Ao: 0 Di: 1 Do: 0 Leuloc: RM 321A

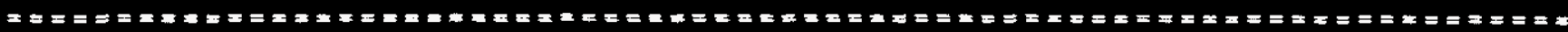

Old pid: 26089-5 Now pit:

Downum: Devtype: LICHT Dovtun: UFS 1/2 ON LINE

Safoty: 3 Loop: XI_ACC2 Loopbun: ACCEL

Dovloc: AM 321A

Intronge: 120 VAC Stetur:

Conments:

Tormb: lob: Torme: loc: Micon: RM321_3_2 Micon_no: 43 Bldo: 234-52
Alorms:

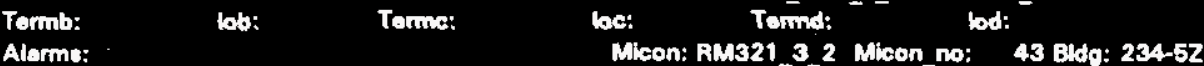

Torma: 321 UA3 II_10 ba: DI_ACCS

Ai: O Ao: O Di: 1 Do: 0 Leuloc: AM $321 \mathrm{~A}$

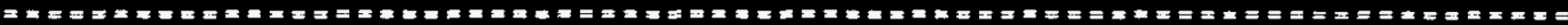

Old_pid: 46884-1 Now_pid:

Dewnum: Devtype: USGT Devtun: POWEA ON

Safoty: 3 Loop: YI_DAE

Loopbun:

Dovoc: RM 321A POWER ON

Cornonto: SEE H-2-08938-4

Termb: bo:

Torme:

Tormo: 321 Vostal: AR-E

Vestol: HVAC

Micon: AM321_3 4 Micon no: 45 Bldg: $234-52$

Al: O Ao: O Di: 1 Do: O Leube: RM $321 \mathrm{~A}$

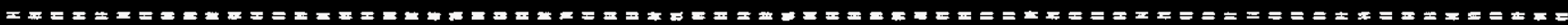

Old_pid: 46884-1 Now_pid:

Dovnum:

Devtype: LISHT

Daviun: POWER ON

Intranes: 120 VAC Status:

Commente: SEE H-2-96422

Tormb: lob:

Sufoty: 3 Loop: YI_DAS Loopbun:

Dovloc: AM 321A POWER ON

Aleme:

Temp:

loc:

Tomn: 32 Veesol: AlR-S

33_V 13 lo: DI DA 15

Ai: O AO: O Di: $1 \mathrm{Do:}$ Oleuloc: RM 321A

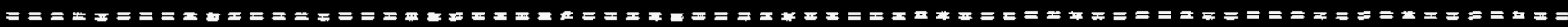
Old pid: 46884-1 Now pid:

Dovnum:

Dovtype: LIGHT

Doviun: STAGE $* 1$ CoOLNG ON Dovoc: AM 321A PANEL $M$

Intrange: 120 VAC Stetus:

Commente: SEF H-296436-4 ("COMPRESSOR "1 OW" ON DAAWING

Tormb:

lab: Loopbun:

Vescol: AlR-E

Alorms: $\quad$ Micon: RM321 34 Micon no: 45 Budg: 234-5z

Ai: 0 Aa: $O$ Di: 1 Do: 0 Lculoc: AM $321 \mathrm{~A}$

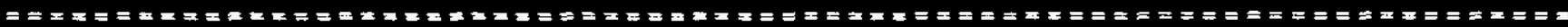

Old pid: 46864-1 Now pid:

Devnum:

Davtrpe: LIOHT

Deviunt

LING ON Devioc: PM 321A PANEL $M$

Intranga: 120 VAC Statua: Safoty: 3 Loop: YI_CU1S

Termb:

ab:

Tomn:

bo:

Tormid: Loopteun: Vosect: AIR-S

Micon: RM321 35 Micon no: 46 Bldd: 23452

Ai: O Ao: O Di: 1 Do: O leuloc: RM 321A

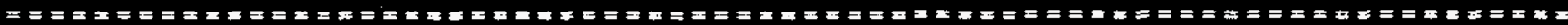

Old pid: 46804-1 New pid:

Dourpa: LIOHT

Devfun: STAGE 22 COOLING ON Dovloc: AM 321A PANEL M

Intrange: 120 VAC Stetus: Safoty: 3 Loop: YI CU2E Loopbun: Vousel: AlR-E

Commento: SEE H-2-96436-4 ("COMPRESSUAE 2 ON" ON DRAAWING) Tomn: 321 UR3_IV_16 loa: DI_CU2E

Tormb: bo: Torme: loc: Ternd:

Micon: RM321 34 Micon_no: 45 Bidg: $234-52$

Ai: O Ao: O Di: 1 Do: 0 Lculoc: RM $321 \mathrm{~A}$

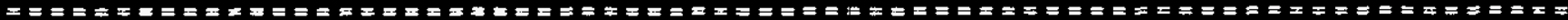

Old pid: 46804-1 Now pid:

Devtype: LIGHT Dovfun: STAGE 22 COOLING ON Dovoc: RM 321A PANEL $M$

Intrange: 120 VAC Status: Safoty: 3 Loop: YICCU2S Loopbun: Voscel: AlR-S

Comments; SEE H-2-96422 ("COMFAFSSOR 2 ON" ON DAAWING) Terma: 321 UR3 V_16 loa: DI_CU25

Termb: lob: Torme: loc: Tormd: lod:

Micon: AM321_3 5 Micon_no: 46 Bldg: 234-52

Ai: 0 Ao: 0 Di: 1 Do: O Lculoc: PM $321 \mathrm{~A}$

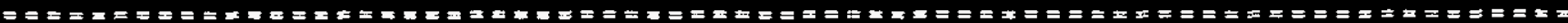

Old_pid: 46804-1 Now_pid:

intrande: 120 VAC Status:

Comments: SEE H-2-96436-4

Devnum:

Dovtype: LIGHT

Dovtur:

Safety: 3 Loop: YISTG1E

Loopbun:

Torma: 321_UA3_N_17 loa: DI_STG1E eescel: AIR-E 


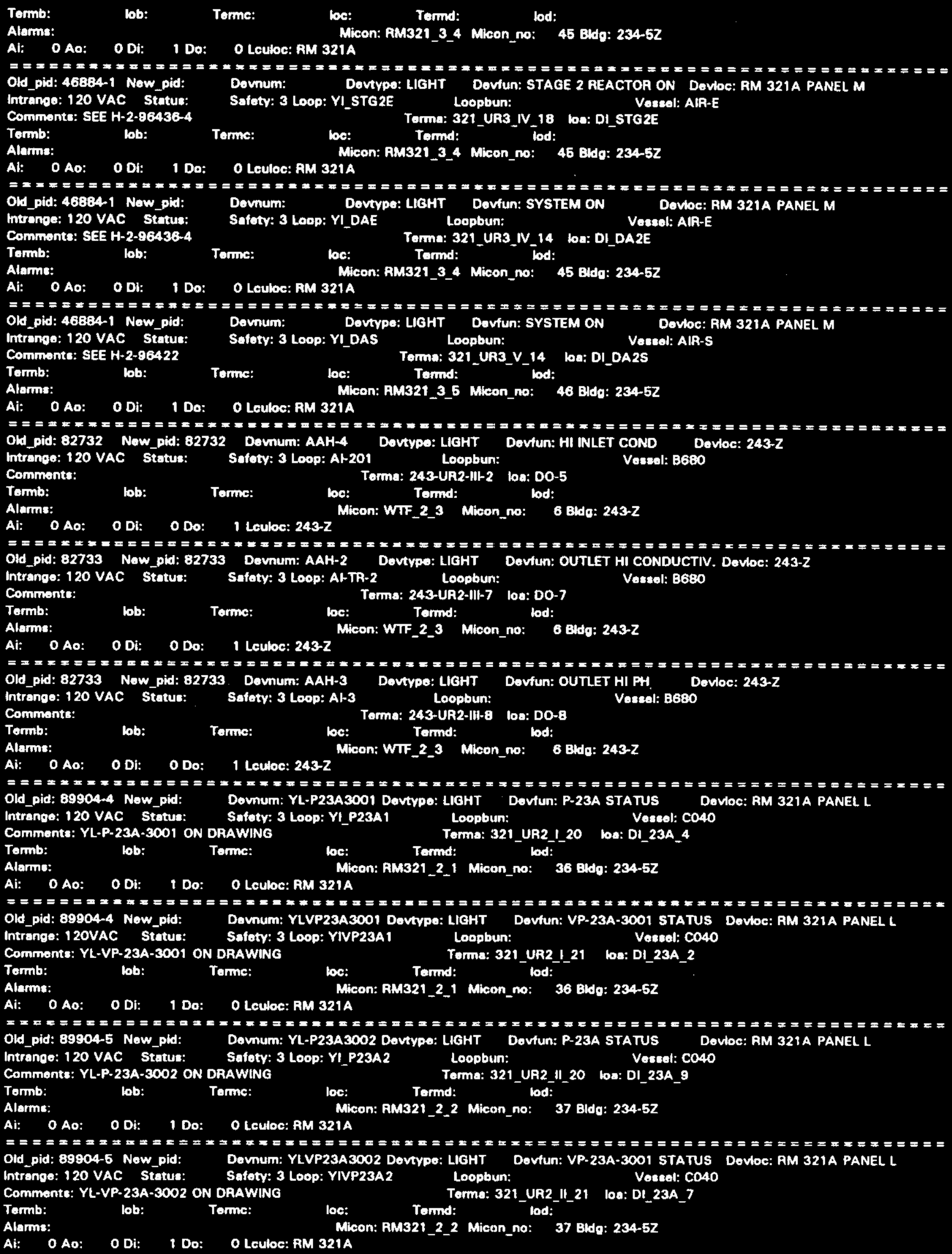




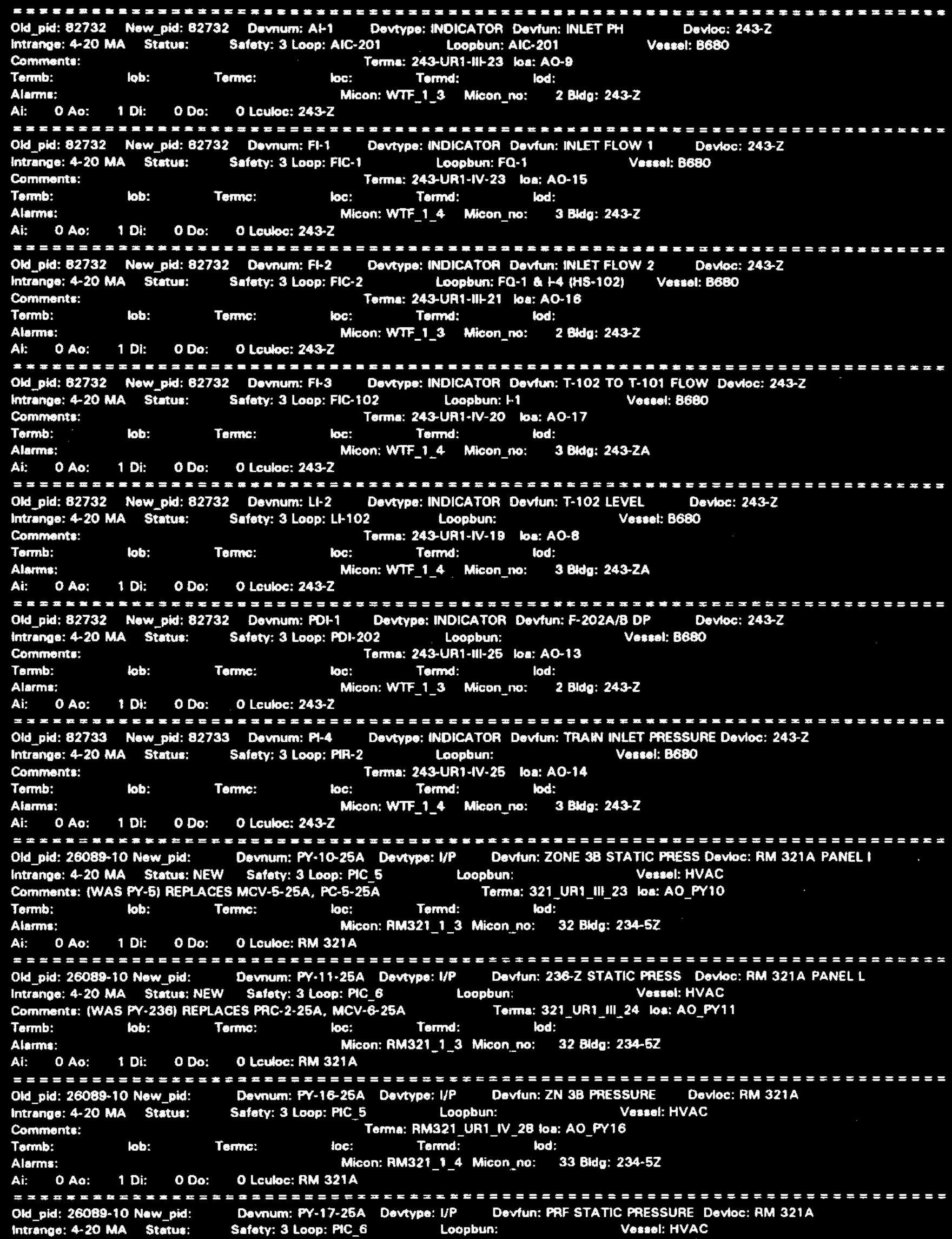




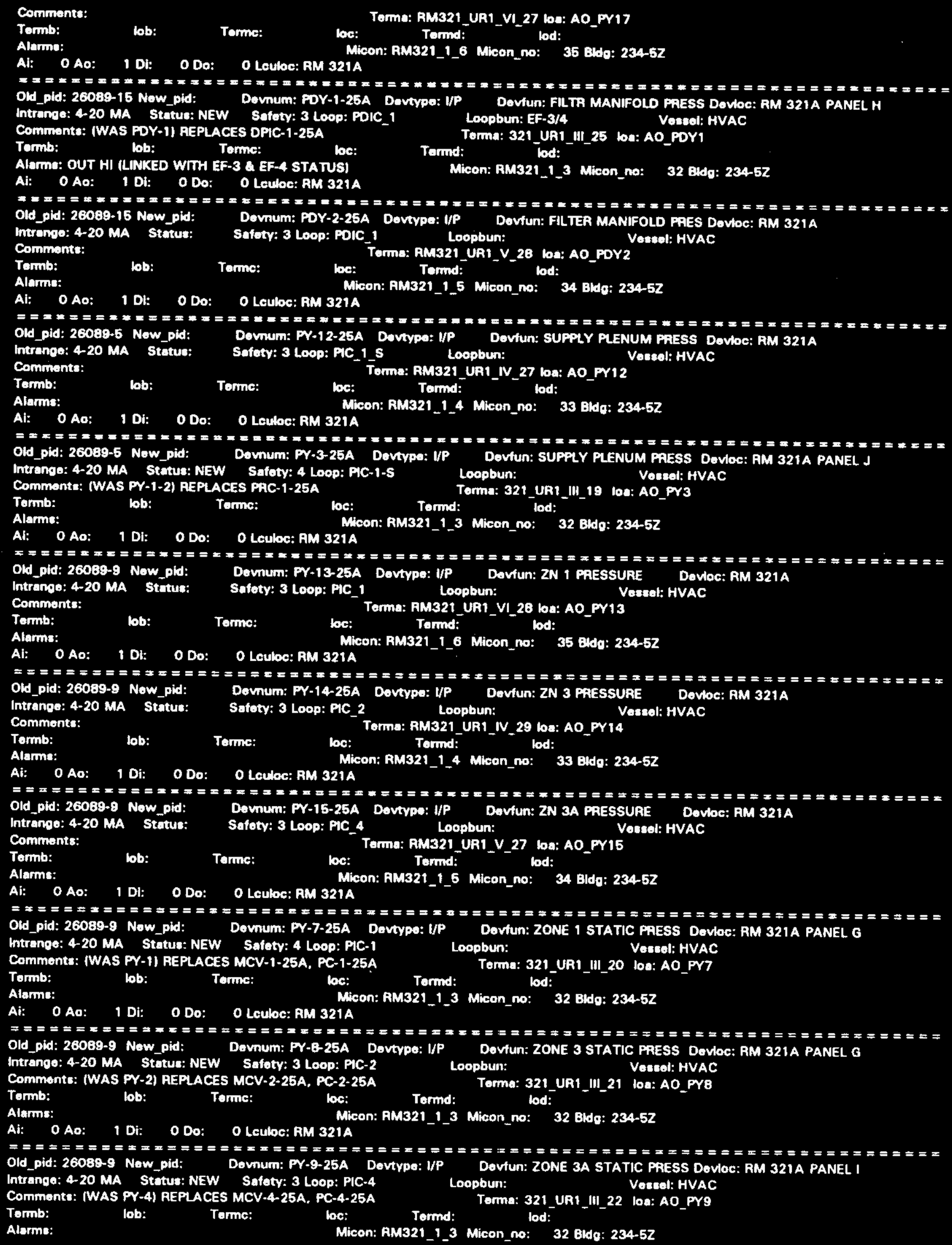




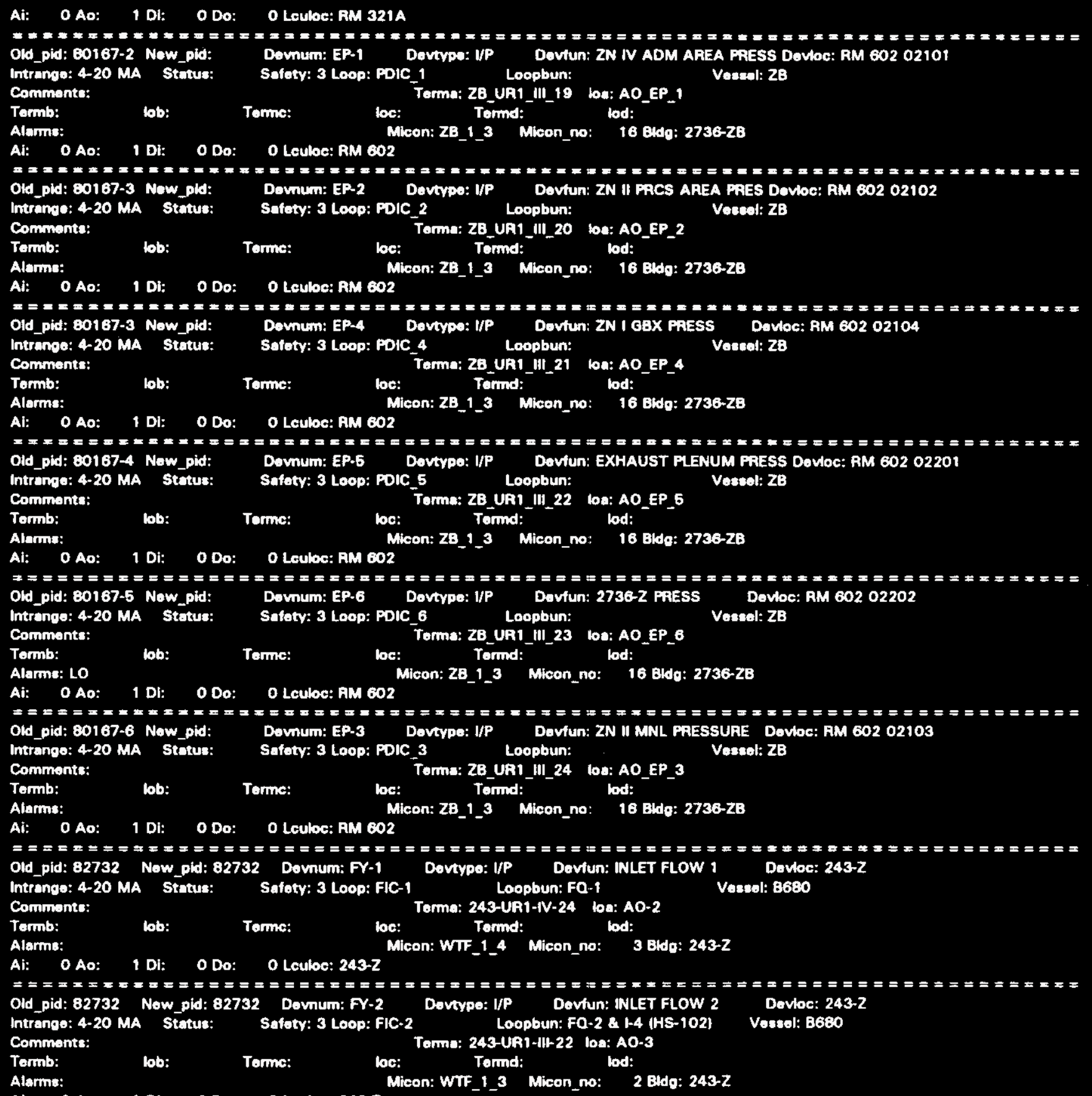

Ai: 0 Ao: 1 Di: 0 Do: 0 Leuloc: $243-2$

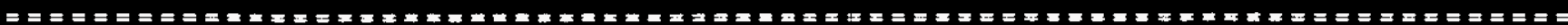
Old_pid: 82732 Now_pid: 82732 Devnum: FY.3 Devtype: UP Dovfun: T-102 TO T-101 FLOW Devloc: $243-2 A$

Intrange: 4-20 MA Status: Safoty: 3 Loop: FIC-101 Loopbun: 1-1 Veseal: B680

Comments: $\quad$ Terma: 243-UA1-IV-21 ba: AO-4

Tormb: lob: Torme: loc: Tornd: lod:

Alarms: $\quad$ Micon: WTF_1_4 Micon_no: 3 Bldo: 243-2A

Ai: OAO: 1 Di: O Do: OLculoc: 243-Z

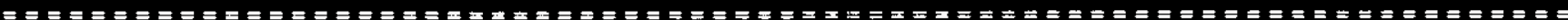
Old_pid: 82732 Now_pid: 82732 Dovnum: LY.1 Devtypo: UP Devfun: T-101 sUMP LEVEL Dovloc: 243-ZA

Intrano: 4-20 MA Status: Safoty: 3 Loop: LIC-101 Loopbun: I-T, H-2, \& 1-3 Vossel: B680

Comments: $\quad$ Torma: 243-UR1-III-19 loa: AO-1

Tormb: lob: Terme: loc: Tornd: lod:

Alarms: $\quad$ Micon: WTF_1_3 Micon_no: 2 8idg: 243-ZA

Ai: 0 Ao: 1 Di: 0 Do: 0 Leuloc: $242-z$

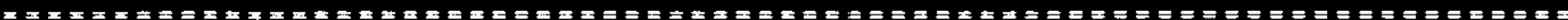

Old_pid: 82732 Now_pid: 82732 Devnum: AY-1 Dovtpe: 1/MET PUMP Dovfun: KOH METER PUMP CONT Dovloc: $243-Z$ 


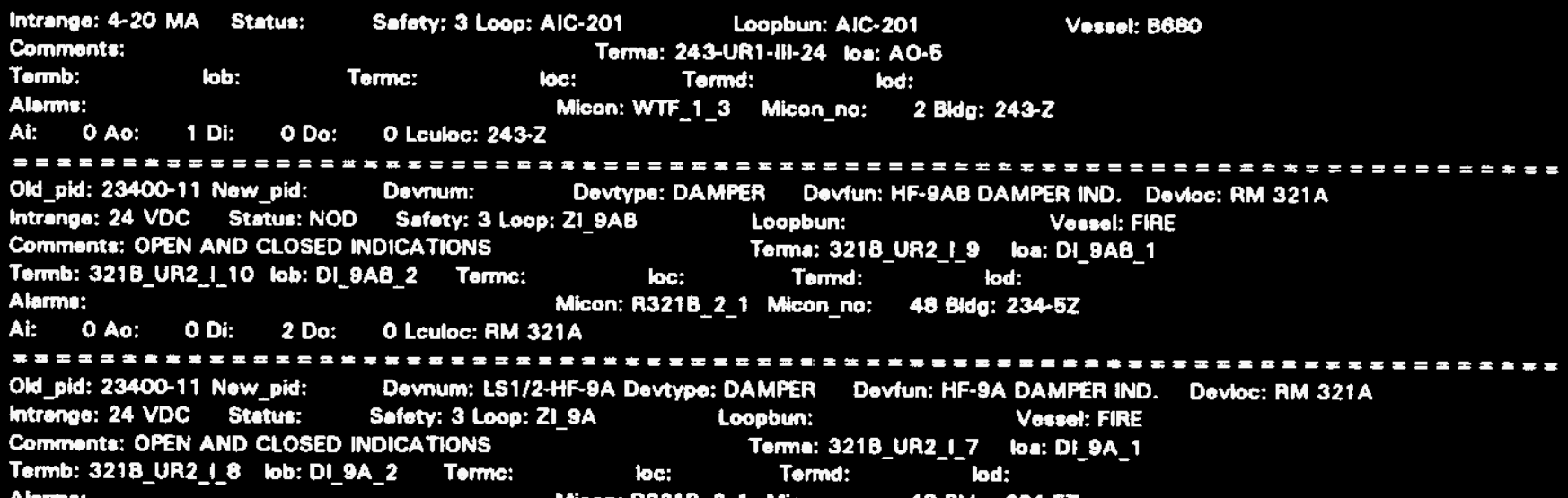
Alams:

Ai: O Ao: O Di: 2 Do: 0 Leuloc: AM $321 \mathrm{~A}$

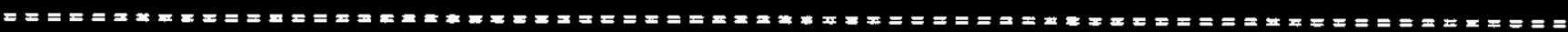
Old_pid: 23400-11 Now_pld: Devnum: LS1/2-HF-88 Dovtypo: DAMPER Dovfun: HF-98 DAMPER IND. Dovloc: AM 321A

Intrange: 24 VDC Status: Safoty: 3 Loop: ZI_8B Loopbun: Varcol: FIRE

Commente: OPEN AND CLOSED INDICATIONS Torma: 3218_UA2_I11 loa: D1_98_1

Tormb: 3218_UR2_L12 lob: DI_98_2 Torme:

Alarme:

loc: Tormd: lod:

Micon: A321B_2 1 Micon_no: 48 Bddg: 234-52

Ai: O Ao: O Di: 2 Do: 0 Leuloc: RM 321A

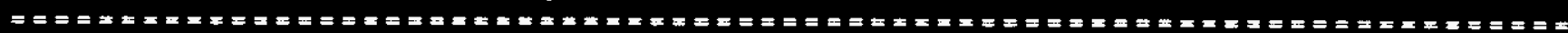
Old_pid: 23400-11 Now_pid: Dovnum: LS1/28YPASS Devtypo: DAMPER Dovfun: 9AB BYPASS IND. Dovloc: RM 321A

Intrange: 24 VDC Status: Safoty: 2 Loop: ZI_BYP Loopbun: Veasel: FIRE

Comments: ON AND OFF INOICATIONS Torma: 321B_UA2_I_1 loa: DI_BYP_1

Termb: 321B_UA2_I_2 lob: DI_BYP_2 Torme: loc: Tomd:

Micon: A321B_2_1 Micon_no: 48 Bldo: $234-52$

Al: OAo: O Di: 2 Do: O Leuloc: RM 321A

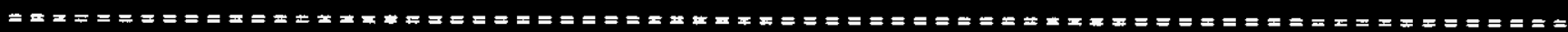
Old_pid: 23400-30 Now_pid: Dovnum: LS1/2-309 Devtype: DAMPER Dovfun: RM 309 DAMPER Dovloc: AM 321A

Intrangs: 24 VDC Statun: Sofoty: 3 Loop: ZI_309 Loopbun: HS_309_10 Vostel: FIRE

Comments: OPEN \& CLOSED INDICATIONS AND OPEN/CLOSE COMM. (K1-SV-2-1A) Torma: 321B_UA2_I_14 bo: OI_309_1

Tormb: 321B_UA2_1_15 lob: DI_309_2 Torme: 321_UA3_V_30 loc: DO_309 Tormd:

Alarm: OPENING 309 DAMPER CLOSED 310 DAMFER Micon: R321B_2_1 Micon_no: 48 Bidg: 234-52

Ai: 0 AO: O Di: 2 Do: 1 Leuloc: RM 321A

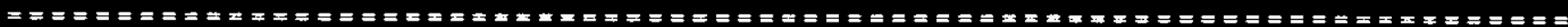

Old_pid: 23400-30 Now_pid: Dovnum: LS1/2-310 Dovtypa: DAMPER Dovtun: AM 310 FIRE DAMPER Dovloc: RM $321 \mathrm{~A}$

Intrange: 24 VDC Stetus: Safoty: 3 Loop: ZI_310 Loopbun: HS_309_10 Voseal: FIRE

Comments: OPEN \& CLOSED WNDICATION AND OPEN/CLOSE COMM. (K1-SV-2-2A) Torma: 3218_UR2_I16 ba: DI_310_1

Tormb: 321B_UR2_!17 lob: DI_310_2 Torme: 321_UR3_V_31 loc: DO_310 Tormd: _ lod:

Alarms: OPENING 310 DAMPER CLOSES 309 DAMPER Micon: R321B_2_1 Micon_no: 48 Bldg: $234-52$

Ai: 0 Ao: 0 Di: 2 Do: 1 Leuloc: RM $321 \mathrm{~A}$

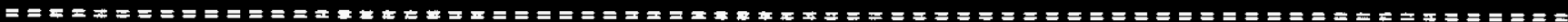
Old_pid: 80167.2 Now_pid: Downum: COND-1 Devtypo: CONDENSER Devtun: CONDENSEA 1 Devloc: RM 602 03701

Intrange: 120 VAC Status: Sofety: 3 Loop: Loopbun: COND1 (SF1/2 COLD SMOKE) Vessel: ZB

Comments: SHUTDOWN SIGNAL - SEE H-2-60142-2 Torma: ZB_UR2_III1 loa: DO_CON_1

Termb: lob: Torme: loc: Tormd: lod:

Alarms: $\quad$ Micon: ZB_2_3 Micon_no: 20 Bida: 2736-ZB

Ai: O Ao: O Di: O Do: 1 Leuloc: RM 602

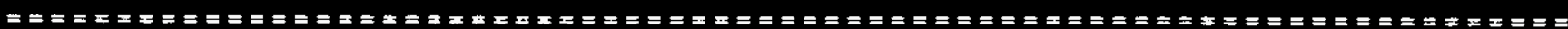

Old_pid: 80167-6 Now_pid: Dovnum: COND-2 Dovtypo: CONDENSER Dovfun: CONDENSER 2 Dovloc: RM 602 O3702

Intrange: 120 VAC Status: · Safoty: 3 Loop: Loopbun: COND-2 (SF3/4) Vescel: ZB

Comments: SHUTDOWN SIGNAL -. SEE H-2-80142-2 Toma: ZB_UR2_Hil5 loa: DO_CON_2

Tormb:

Alarms: $\quad$ Micon: ZB_2_3 Micon_no: 20 Bidg: 2736-ZB

Ai: OAo: O Di: O Do: 1 Leuloc: RM 602

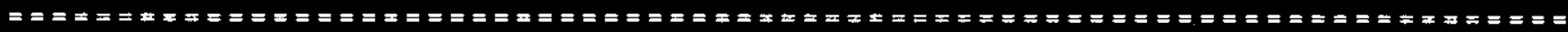
Old_pid: 80167-6 Now_pid: Dovnum: NDA CAMS Dovtypa: CAM Doviun: NDA AREA CAM ALARM Devloc: RM 60213412

Intrangs: 24 VDC Status: Safety: 3 Loop: RAH_NDA Loopbun: EV19 Versel: ZB

Comments: $\quad$ Torma: ZB_UP2_IV_10 loa: DI_CAM

Tormb: lob: Terme: loc: $\quad$ Micon: ZB_2_4 Micon no: 21 Bldg: 2736-ZB
Alarms:

Ai: OAo: O Di: 1 Do: 0 Lculoc: RM 602

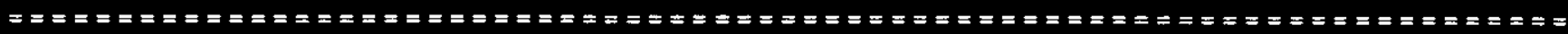
Old_pid: 23400-30 Now_pid: Dovnum: RESET Devtypo: BUTTON Dovfun: 309/10 DP/DAMP RESET Dovloc: AM 321A

Intrangs: 24 VDC Statur: Safoty: 3 Loop: HS_RES Loopbun: Vossol: FIRE

Comments: $\quad$ Torma: 321 UA3_IV_28 los: DO_RES 1

Tormb: 321 UR3_IV_29 lob: DO_RES_2 Tormc: 321_UR3_IV_30 loc: DO_RES_3 Tormd: 321 UR3_IV_31 lod: DO_RES_4 


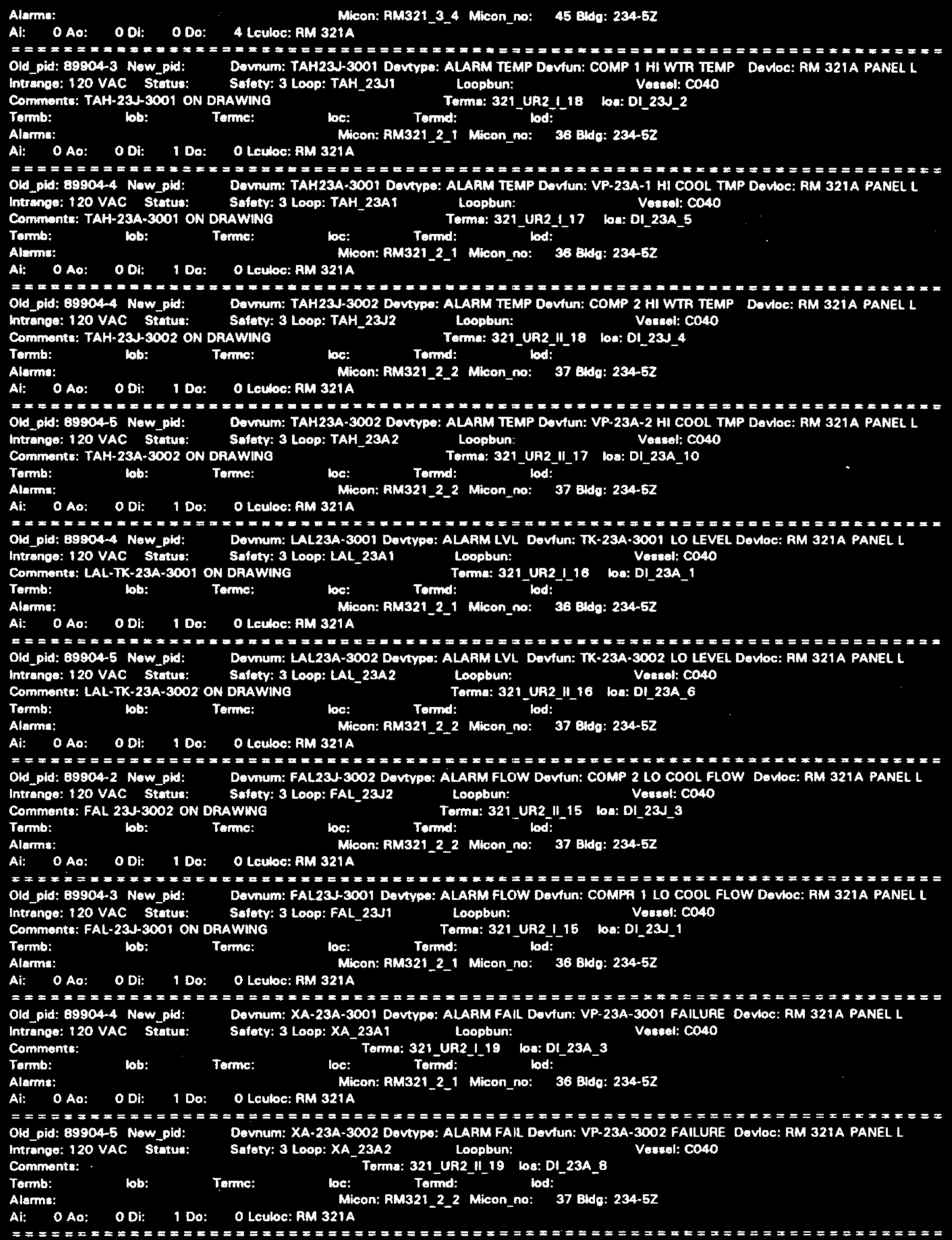




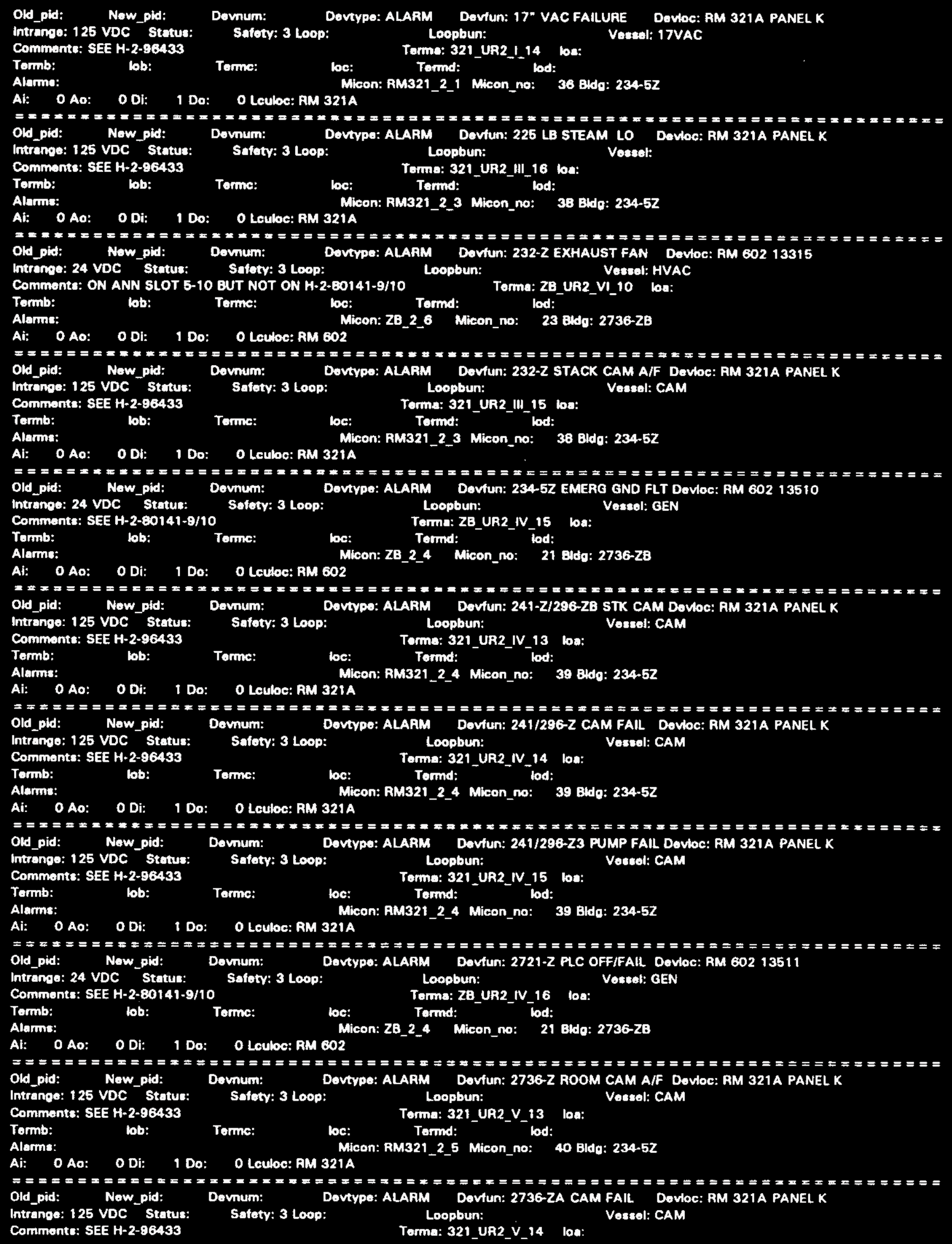




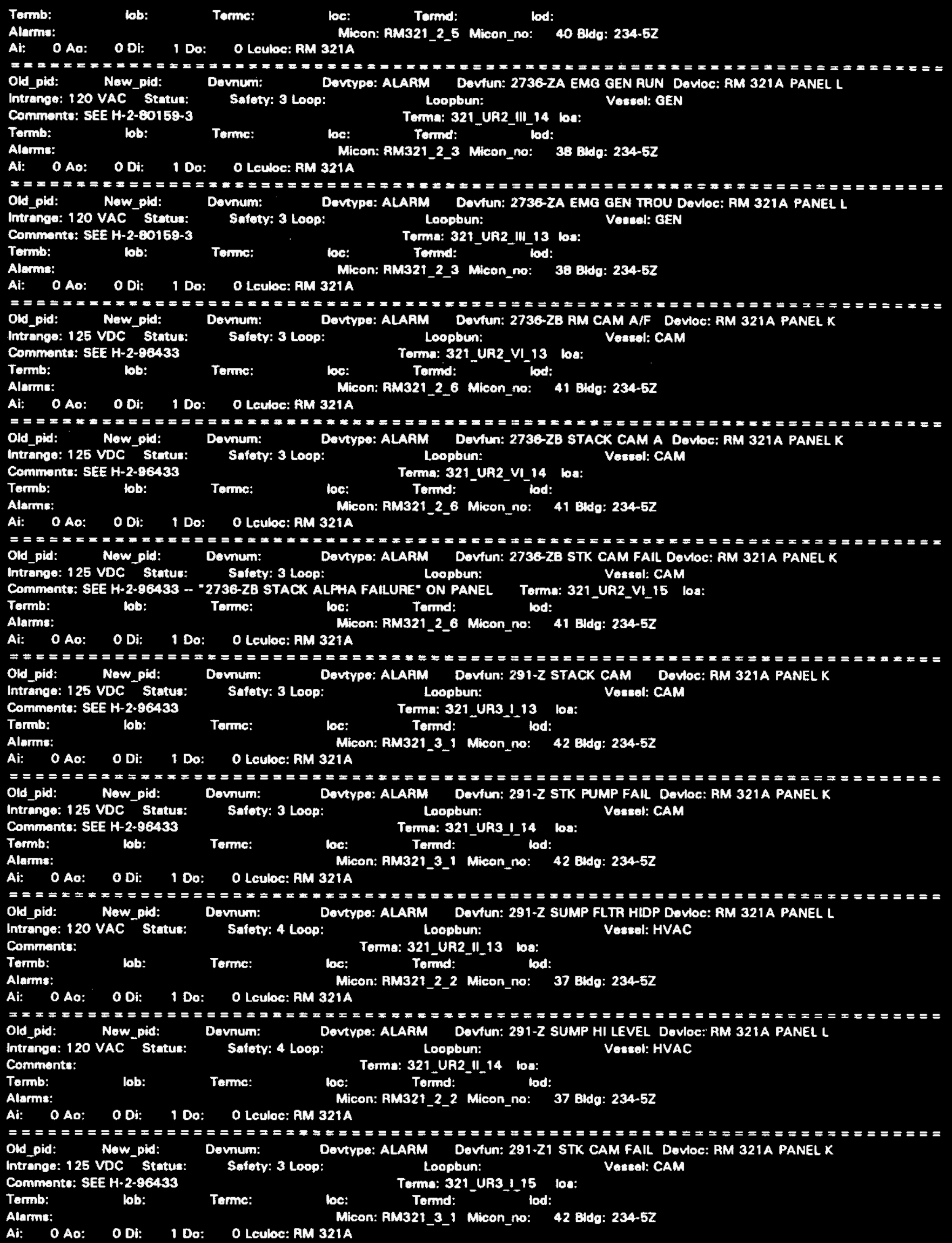




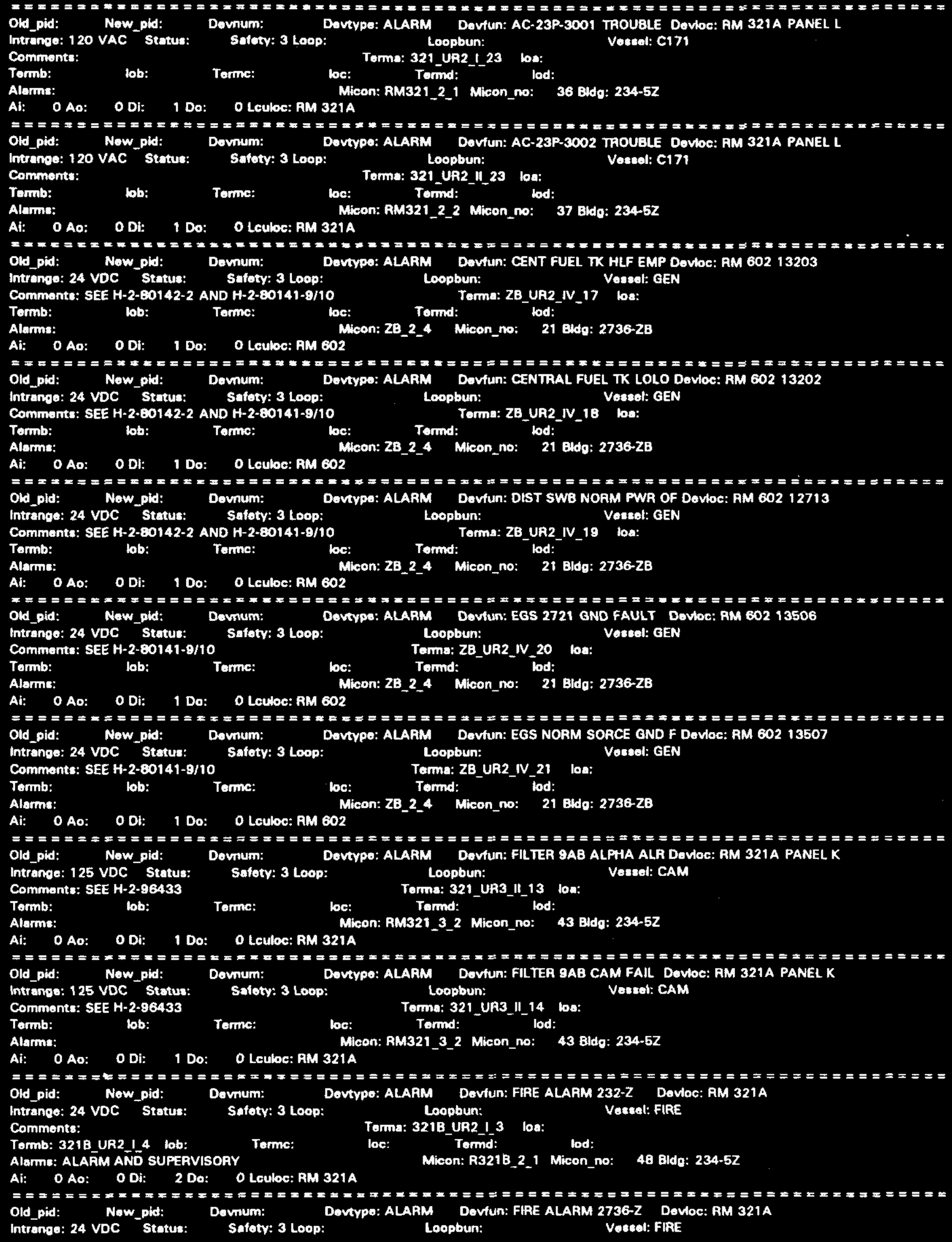




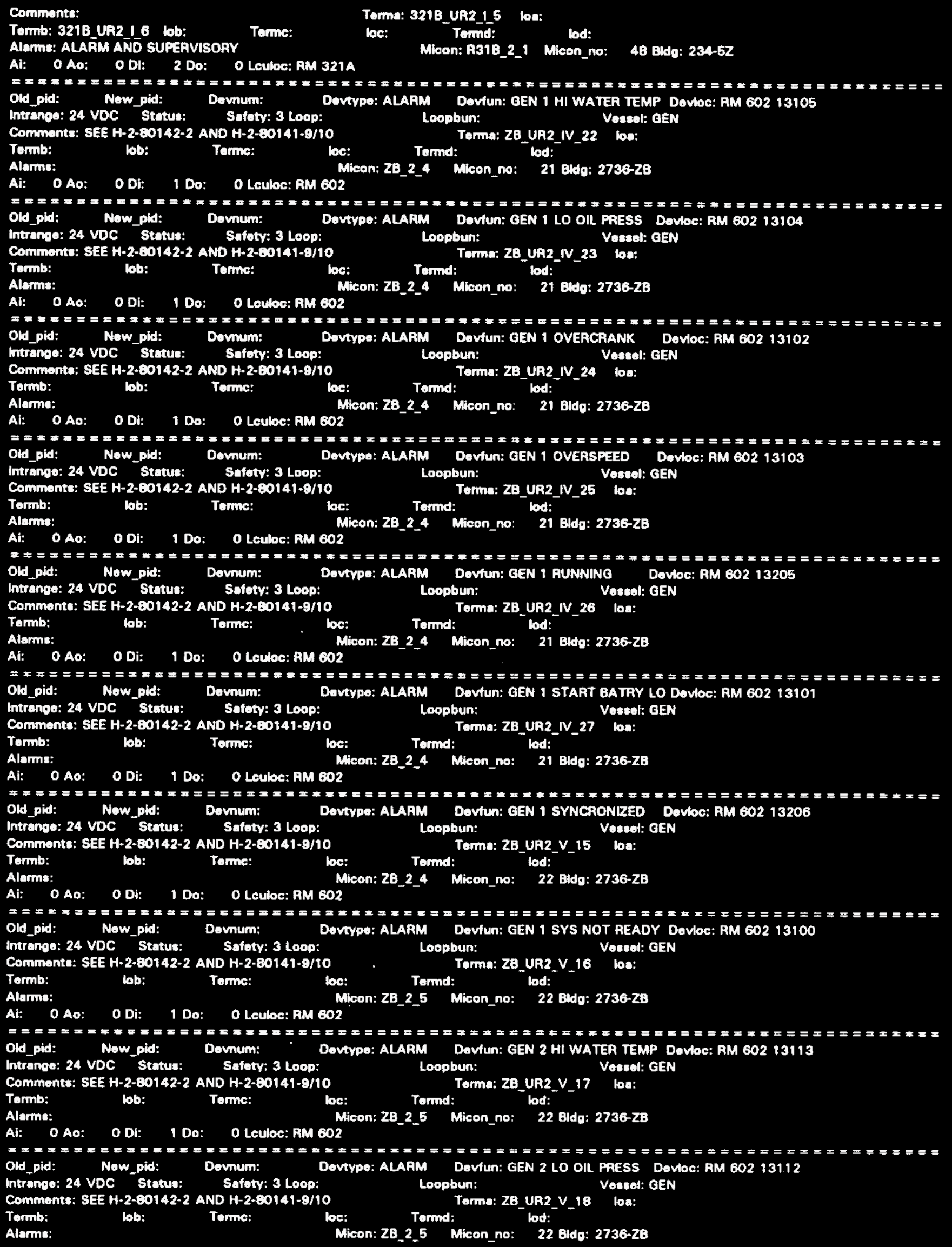


Ai: 0 Ao: 0 Di: 1 Do: 0 Leulec: AM 602

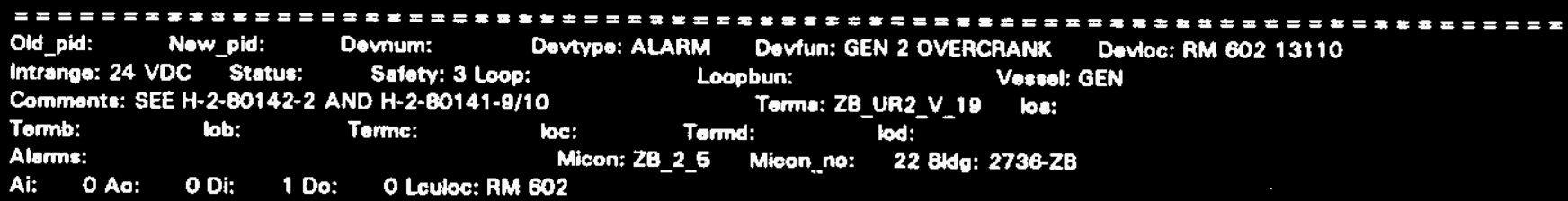

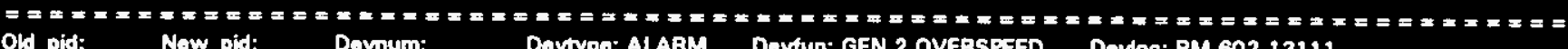
Dovnum: Dovtypo: ALARM Devfun: GEN 2 OVERSPEED Dovbe: RM 60213111

Safoty: 3 Loop: Loopbun: Vescel: GEN

$\begin{array}{lllllll}\text { Tormb: } & \text { bb: Torma: ZB_UA2_V_20 loa: }\end{array}$

Alarms: $\quad$ Micon: 2B_2_5 Micon_no: 22 8dde: $2738-28$

Al: OAo: O Di: 1 Do: O Leuloc: AM 602

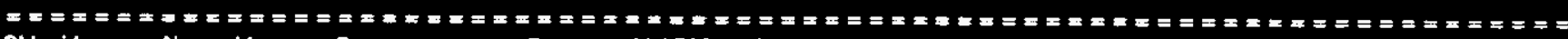
Old_pid: Now_pld: Dovnum: Davtype: ALARM Doviun: GEN 2 RUNNINO Dovoc: AM 602 13210

Intrange: 24 VDC Stotus: Safoty: 3 Loop: Loopbun: Vescel: GEN

Comments: SEE H-2-80142-2 AND H-2-80141-9/10 $\quad$ be: Tomc: $\quad$ Tob:
Tomb:

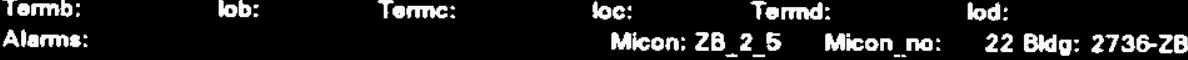

Ai: 0 Aa: 0 Di: 1 Do: 0 Leube: AM 602

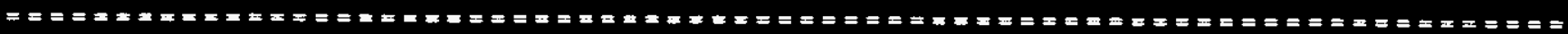

Old_pid: Now_pid: Dovnum: Dovtype: ALARM Dovfun: GEN 2 START BATRY LO Devtoc: RM 602 13107

Intrange: 24 VDC Stetua: Sofoty: 3 Loop: Loopbun: Vossel: GEN

$\begin{array}{lllll}\text { Commente: SEE H-2-80142-2 AND H-2-80141-9/10 } & \text { Terma: ZB_UA2_V_22 loa: } \\ \text { Tarmb: } & \text { lob: } & \text { Tormc: }\end{array}$

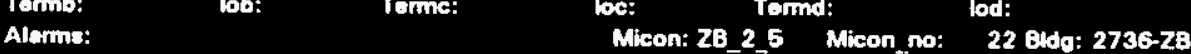

Al: 0 Ao: 0 Di: 1 Do: 0 Leuloc: RM 602

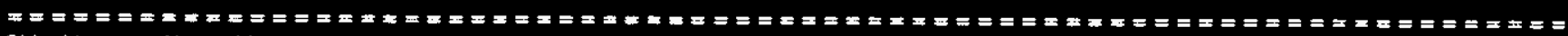

Old_pid: Now_pid: Devmum: Dovype: ALARM Dovfun: GEN 2 SYNCRONIZED Dovioc: RM 602 13211

Intrang: 24 VDC Status: Safoty: 3 Loop: Loopbun: Voses: GEN

Comments: SEE H-2-80142-2 AND H-2-80141-9/10

Termb:

bb:

Terms:

loc:

Tormo:

Torma: Z8_UA2 V 23 bo:

Alarma: 0 Aa: 0 Dl: 1 Do: 0 Lculoc: RM 602

OAa: O Dl: 1 Do: 0 Louloc: RM 602

Old_pid: Now_pid: Devnum:

Intrange: 24 VDC Status: Safoty: 3 Loop:

Comments: SEE H-2-80142-2 AND H-2-80141-8/10

Tormb: lob: Tormc: loc:

Dovtypo: ALARM Dovin: GEN 2 SYS NOT READY Dovloc: AM 60213106

Alarms:

Ai: 0 Ao: $O$ Di: 1 Do: 0 leulac: RM 602

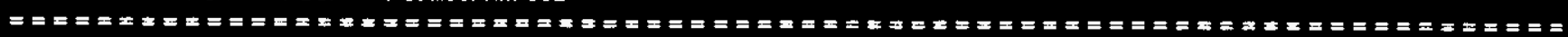
Old_pid: Now_pid: Devnum: Dovtype: ALARM Doviun: GEN 3 HI WATER TEMP Dovioc: AM 602 13201

Intrande: 24 VDC Status: Safoty: 3 Loop:

Comments: SEE H-2-80142-2 AND H-2-80141-9/10

Tomb:

Tome: Loopbun:

Veseal: GEN

Alarms: $\quad$ Micon: ZB_2_5 Micon_no: 22 81dg: $2736-28$

Ai: O Aa: O Di: 1 Do: OLculoc: AM 602

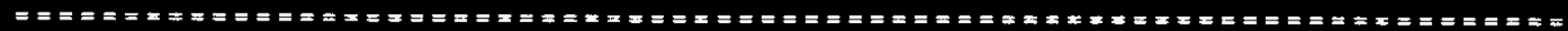
Old_pid: Now_pid: Devnum: Dovtypo: ALARM Dovtun: GEN 3 LO OLL FRESS Dovloc: RM 60213200

Intrange: 24 VDC Status: Safoty: 3 Loop:

Commente: SEE H-2-80142-2 AND H-2-80141-9/10

Tormb: lob: Torme: loc:

Alerms: 1 Ao: 0 Di: 1 Do: O Leubc: RM 602

Ai: O AO: O Di: 1 Do: O Leuloc: RM 602 Micon_no: 22 Bdo: 2736-Z8

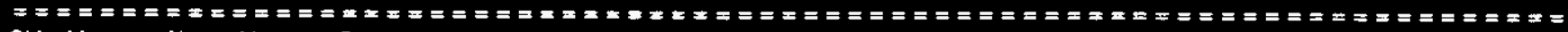
Old_pid: Now_pid: Devnum: Dovtype: ALARM Doviun: GEN 3 OVERCRANK Devloc: RM 602 13116

Intrange: 24 VDC Status: Safety: 3 Loop:

Commente: SEE H-2-80142-2 AND H-2-80141-9/10

Tomb: lob: Tormc: loc:

Alarms: 0 Ao: 0 Di: 1 Do: 0 Leuloc: RM 602

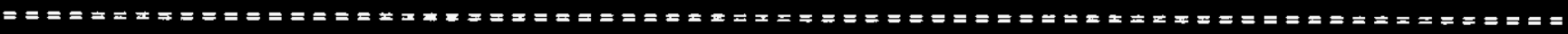
Old_pid: Now_pid: Devnum: Devtype: ALARM Dovfun: GEN 3 OVERSPEED Dovloc: RM 602 13117

Intranga: 24 VDC Status: Sototy: 3 Loop: Loopbun: Vocsel: GEN

Commonts: SEE H-2-80142-2 AND H-2-80141-9/10

Termb: lob: Torme: loc:

Alarms: 1 Ao: 0 Di: 1 Do: 0 Leuloc: RM 602

23 Bidg: 2736-ZB

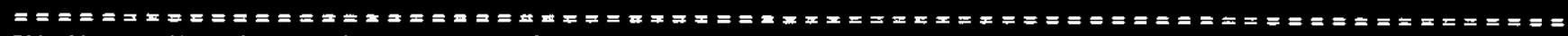

Old_pid: Now_pid: Dovnum: Dovtype: ALARM Dovfun: GEN 3 RUNNING Davoc: AM 60213213 


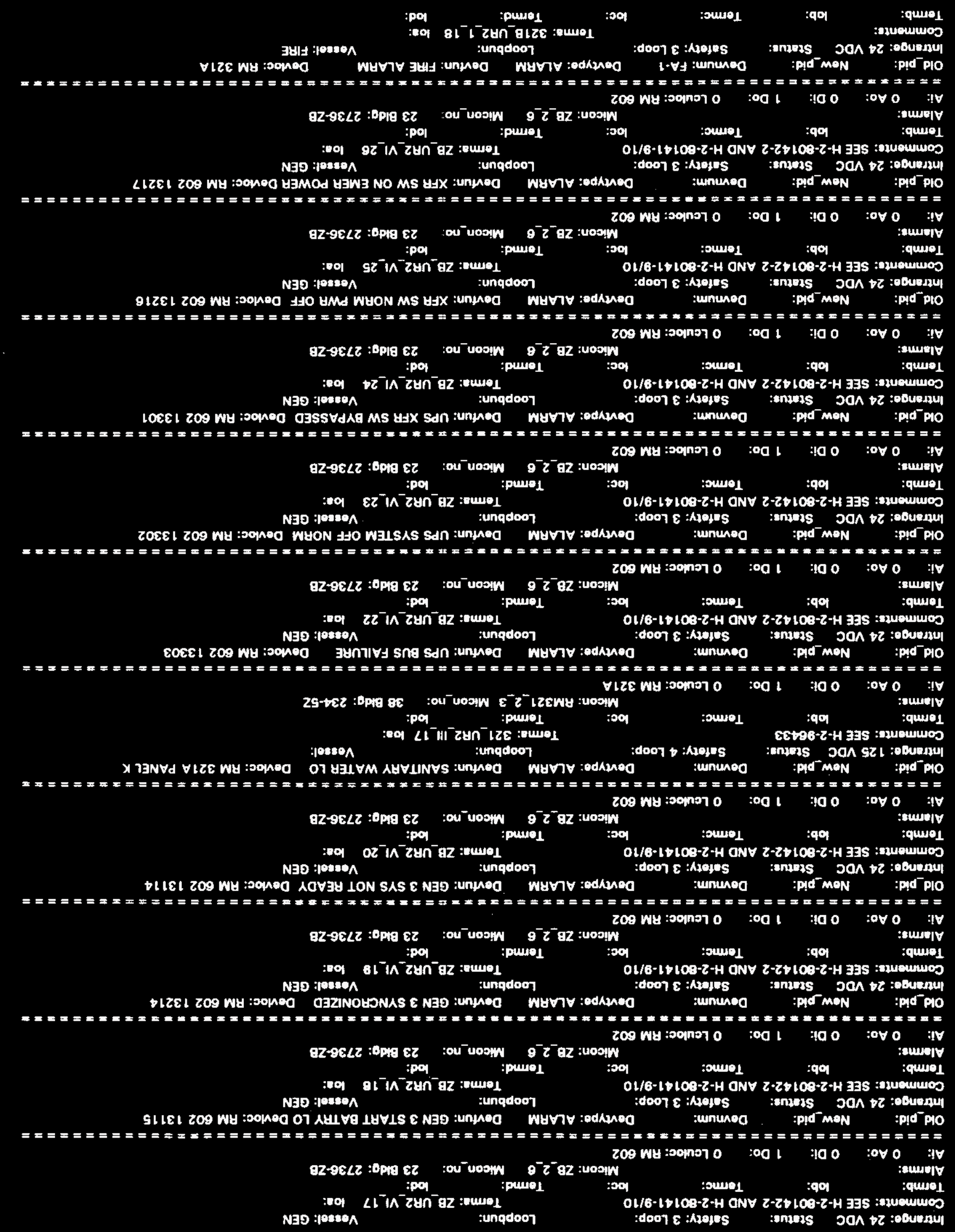




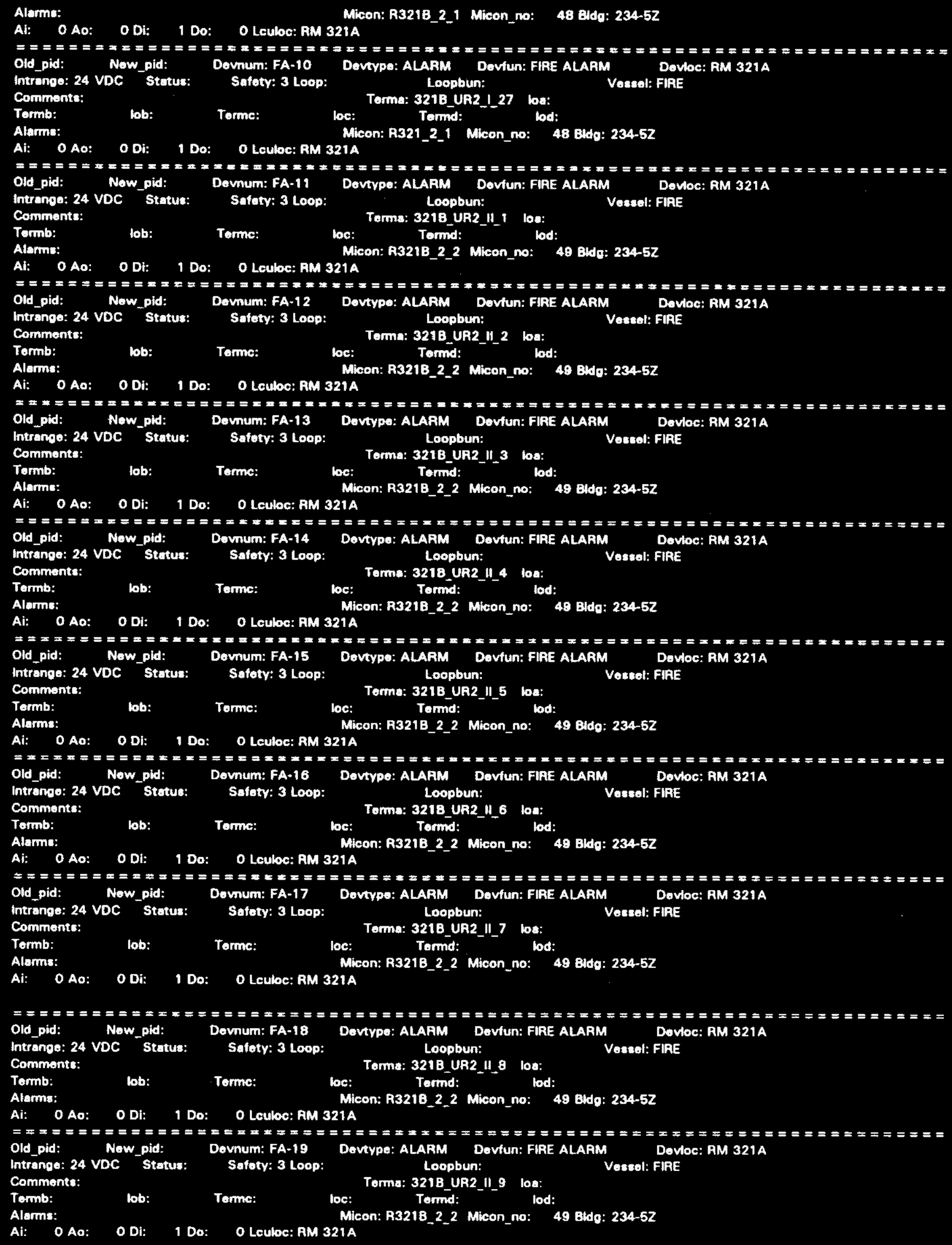




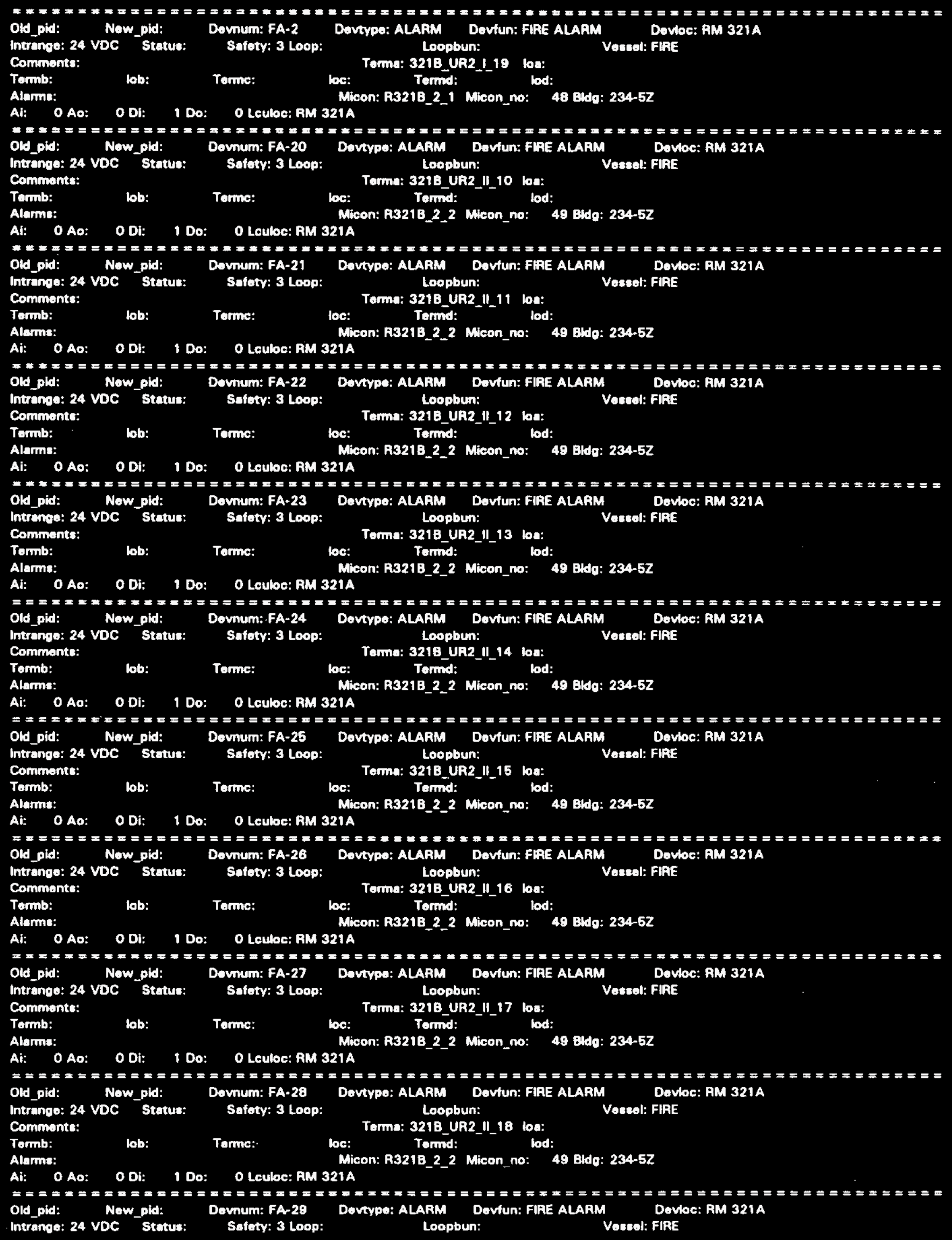




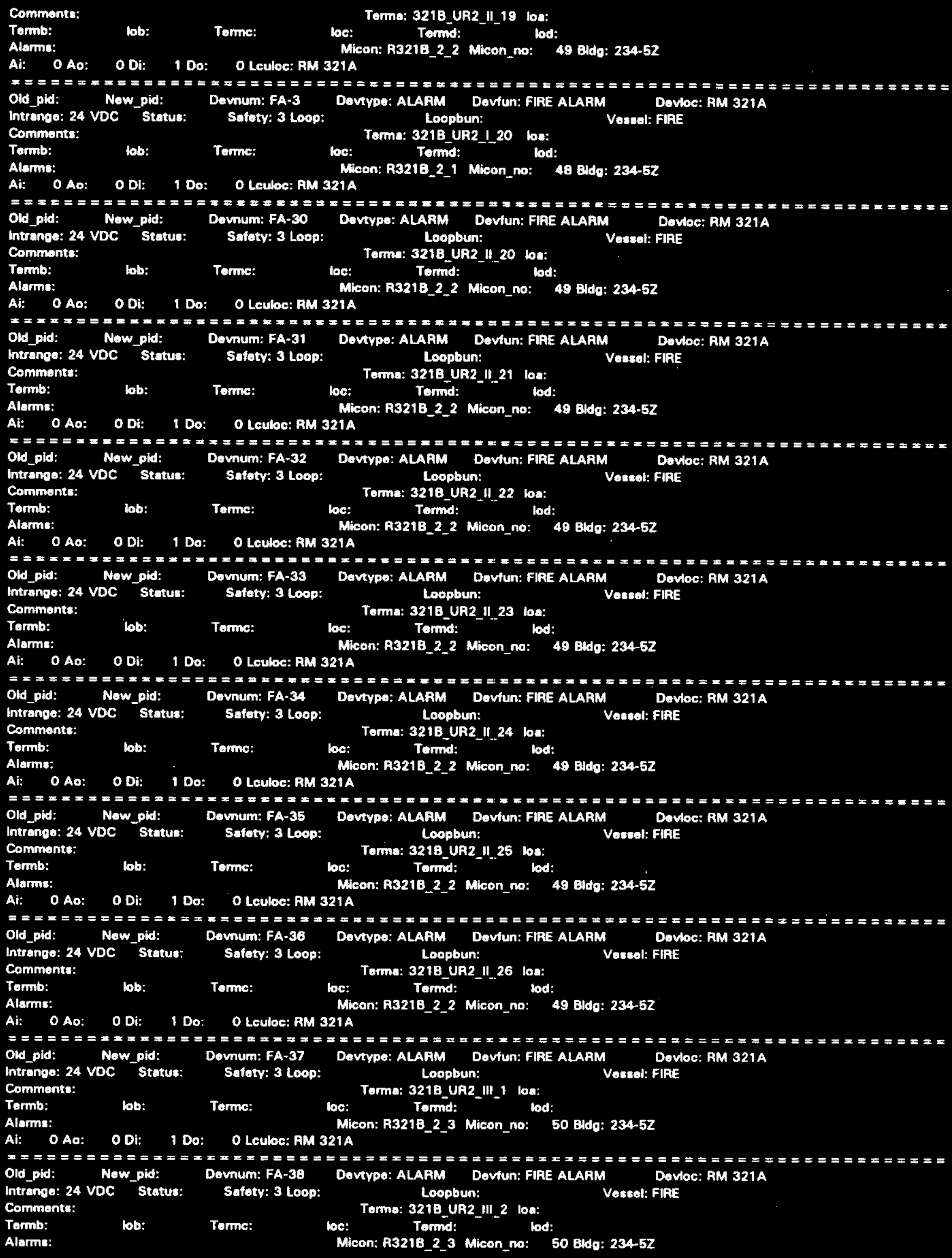


Ai: O Ao: O Di: 1 Do: O Leuloc: RM $321 \mathrm{~A}$

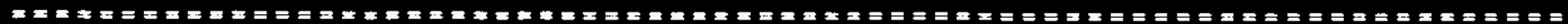
Old_pid: Now pid: Dovnum: FA-39 Dovtype: ALARM Davfun: FIRE ALARM Dovoc: RM 321 A

Imtrango: 24 VDC Status: Safoty: 3 Loop: Loopbun: Voseal: FIAE

Commente: $\quad$ Terma: 321B_UA2_III_3 be:

Tormb: lab: Torme: loc: Tormd:

Ai: 0 Ao: 0 Di: 1 Do: 0 Leuloc: RM $321 \mathrm{~A}$

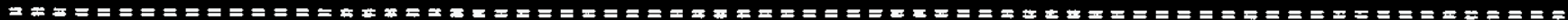
Old_pid: Now_pid: Dovnum: FA-4 Dovypo: ALARM Dovfun: FIRE ALARM Dovloc: RM 321 A

Intrange: 24 VOC Stetus: Safoty: 3 Loop: Loopbun: Vosel: FIRE

Comments: $\quad$ Tormo: 3218_UA2_1_21 loa:

Tomb: lob: Tornc: loc: Tormd: lod:

Alams: $\quad$ Micon: R321B_2_1 Micon_no: 48 Bddo: 234-52

Ai: O Aa: O Di: 1 Do: O Leube: AM $321 \mathrm{~A}$

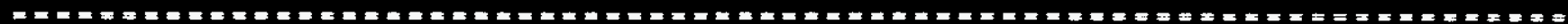

Old_pid: Now_pid: Dovnum: FA-40 Dovtrpe: ALARM Doviun: FIAE ALARM Dovoc: RM 321A

Intronoe: 24 VDC Stotus: Sofoty: 3 Loop: Loopbun: Voscel: FIFE

Commonts: $\quad$ Terma: 321B_UR2_III_4 loa:

Termb: lob: Tormc: loc: Tormd: lod:

Alarms: $\quad$ Micon: R321B_2_3 Micon_no: 50 Bdo: $234-52$

Ai: 0 Ao: 0 Di: 1 Do: 0 Lauloc: RM 321A

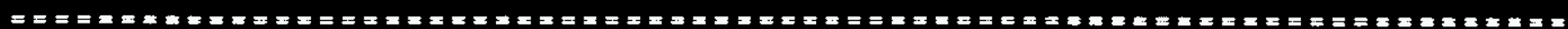

Old pid: Now_pid: Dounum: FA-41 Dovypo: ALARM Deviun: FIRE ALARM Dovoc: RM 321A

Intrango: 24 VDC Stetus: Safoty: 3 Loop: Loopbun: Vossel: FIAE

Commonta: $\quad$ Torma: 3218_UR2_ll16 loa:

Tormb: bo: Torme: be: Tormat: lod:

Alarms: $\quad$ Micon: A3218_2_3 Micon_no: 50 Bldo: 23462

Ai: O Ao: 0 Di: 1 Do: O Lculoc: AM 321A

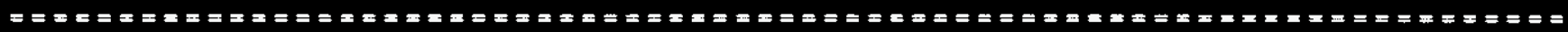

Old pld: Now pid: Dovnum: FA-42 Doverpa: ALAAM Dovfun: FIAE ALARM Dovioc: RM 321 A

Intrange: 24 VDC Stotus: Sofoty: 3 Loop: Loopbun: Veasel: FIAE

Comments: $\quad$ Terma: 3218 UR2_II_6 lon:

Tormb: lob: Torme: loc: Tormit:

Alarm: $\quad$ Micon: R3218_2_3 Micon_no: 50 Bddo: 234-5Z

Ai: O Ao: O Di: 1 Do: 0 Lculoc: RM $321 \mathrm{~A}$

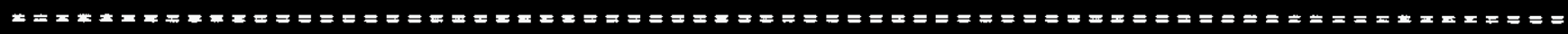

Old pid: Now pid: Dovnum: FA-43 Dovtypa: ALARM Dovfun: FIRE ALARM Dovioc: AM 321A

Intrange: 24 VDC Status: Sufoty: 3 Loop:

Commonts:

Tomb:

lob: Tormc: Loopbun:

Vesest: FIRE

Micon: A3218_2_3 Micon_no: 50 Bddg: 234-52

Ai: O Ao: 0 Di: 1 Do: 0 Leuloc: AM $321 \mathrm{~A}$

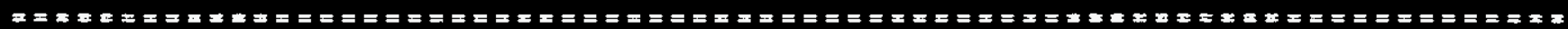
Old_pid: Now_pid: Dovnum: FA-44 Dovtype: ALARM Devfun: FIRE ALARM Dovloc: RM 321A

Intrange: 24 VDC Stotus: Safoty: 3 Loop: Loopbun: Veal: FIRE

Comments: $\quad$ Torma: 3218 UR2_lil_8 loa:

Termb: lob: Torme: loc: Terind: ${ }_{\text {lod: }}$

Alarms: $\quad$ Micon: R321B 2.3 Micon no: 50 Bldo: $234-52$

Ai: 0 Ao: O Di: 1 Do: 0 Leuloc: AM $321 \mathrm{~A}$

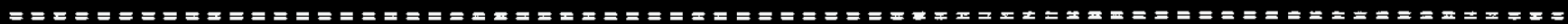

intrange: 24 VDC Stotus: Safoty: 3 Loop: Loopbun: Vosel: FIAE

Comments: $\quad$ Toma: 321B_UR2_IlI_9 loa:

Tormb: lob: Tornc: loc: Tormd:

Alams: $\quad$ Micon: R3218_2_3 Micon_no: 50 81d9: 234-52

Ai: O Ao: O Di: 1 Do: 0 Lculoc: RM 321A

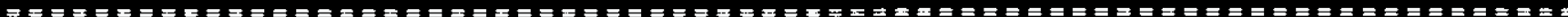
Old_pid: Now_pid: Dovnem: FA-46 Devtype: ALARM Doviun: FIRE ALARM Dovloc: RM 321A

Intranos: 24 VDC Stetus: Safoty: 3 Loop: Loopbun: Vecel: FIRE

Comments: $\quad$ Terma: 3218_UA2_III_10 loa:

Tormb: lob: Terme: loc: Tormd: lod:

Alarms: $\quad$ Micon: A3218_2_3 Micon_no: 50 Blds: 234-52

Ai: O Ao: O Di: 1 Do: 0 Leubs: RM 321A

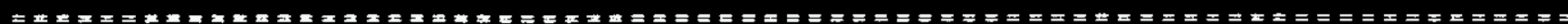
Old_pid: Now_pid: Devnum: FA-47 Dovtype: ALARM Dovfun: FIRE ALARM Devloc: RM 321A

Intrange: 24 VDC Stotus: Satety: 3 Loop: Loopbun: Vestel: FIRE

Commonte: $\quad$ Torma: 321B_UR2_l1__11 lon:

Termb: lob: Torme: loc: lood:

Alarms: $\quad$ Micon: R321B_2_3 Micon_no: 50 Budg: 234-52

Ai: 0 Ao: 0 Di: 1 Do: 0 Lculoc: RM $321 \mathrm{~A}$

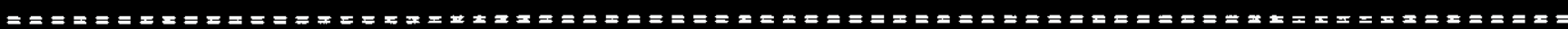

Old.pid: Now_pid: Dovnum: FA-48 Dovtype: ALARM Doviun: FIAE ALARM Dovloc: RM 321A 
WHC-SD-610-PSAR-002 REV 1

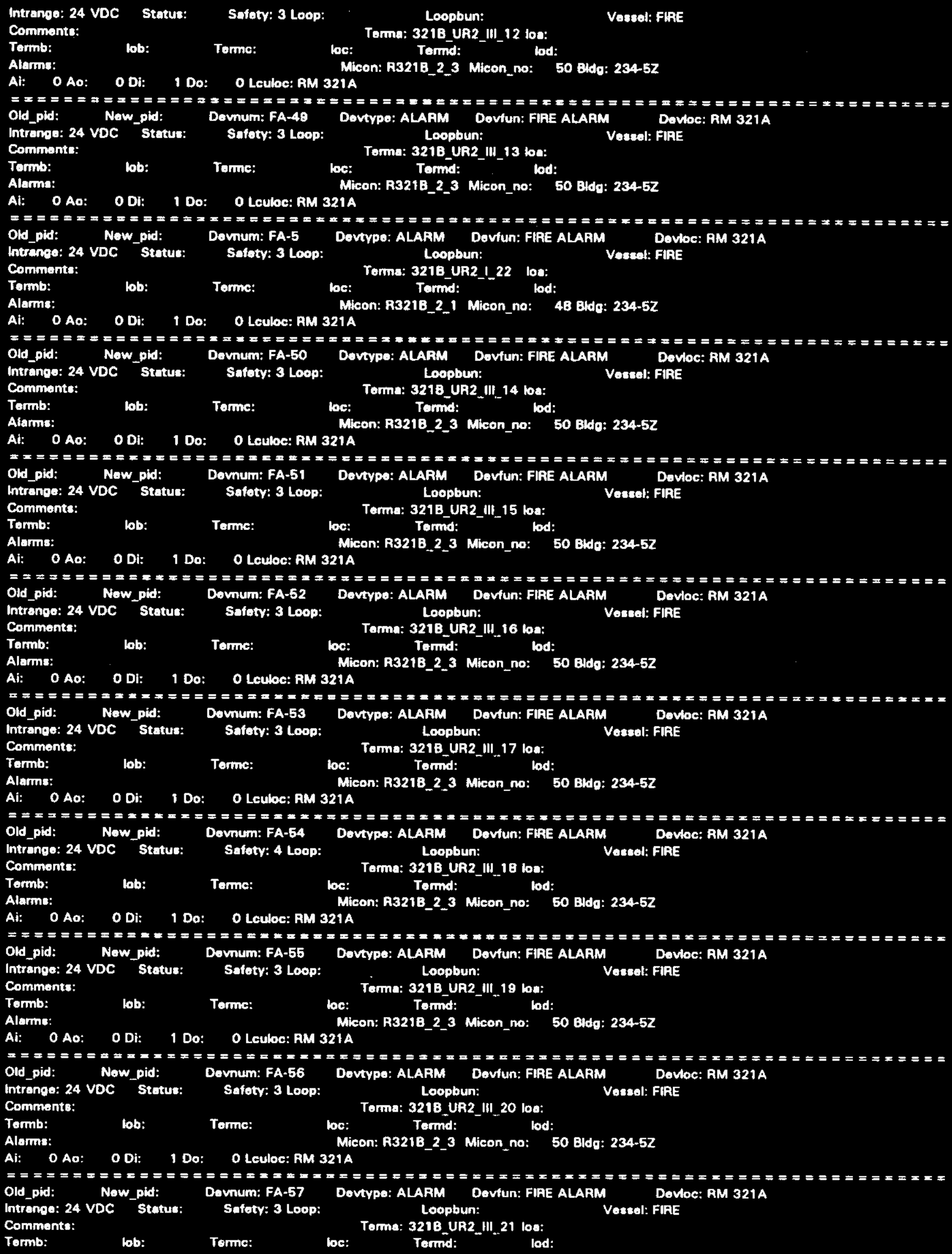




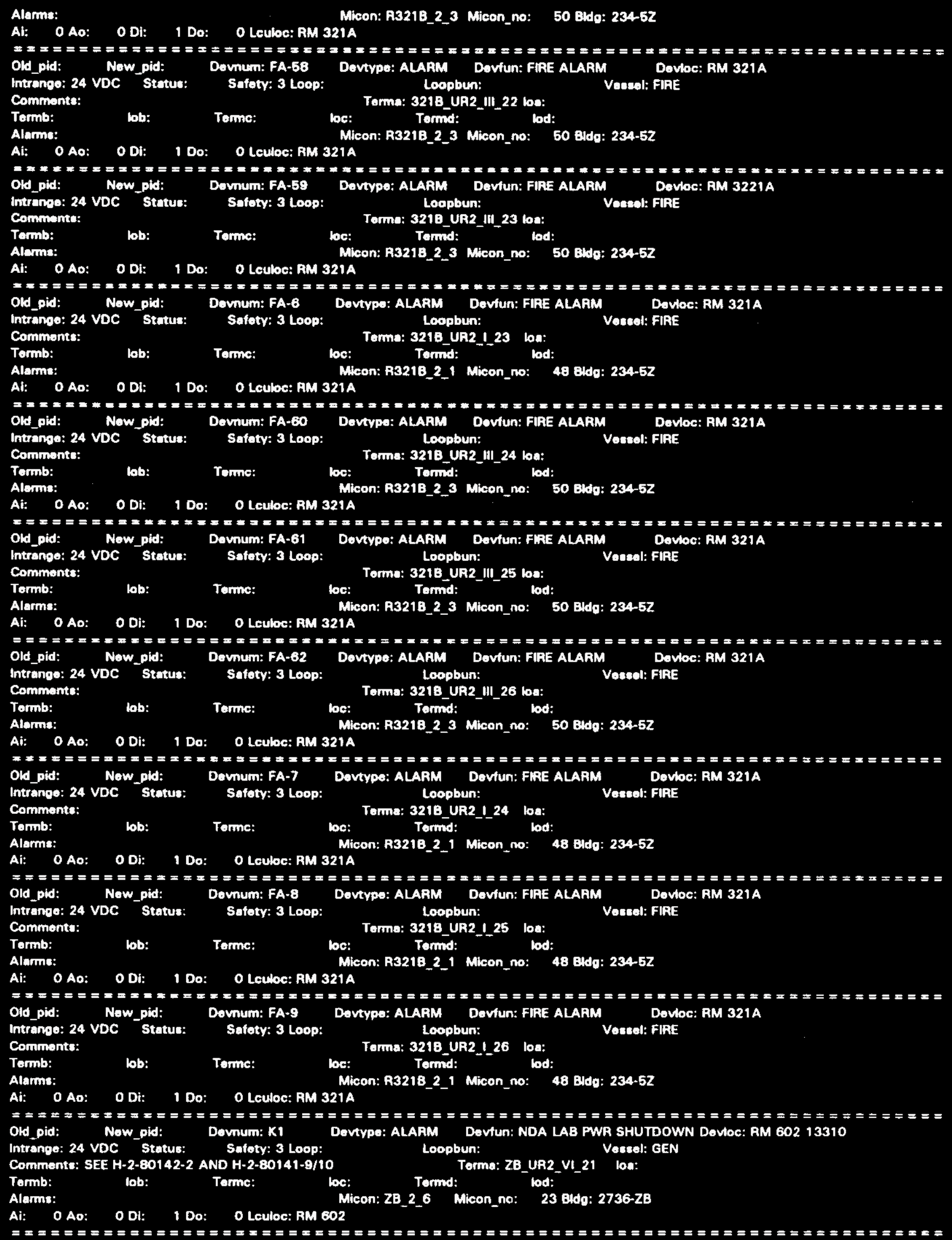




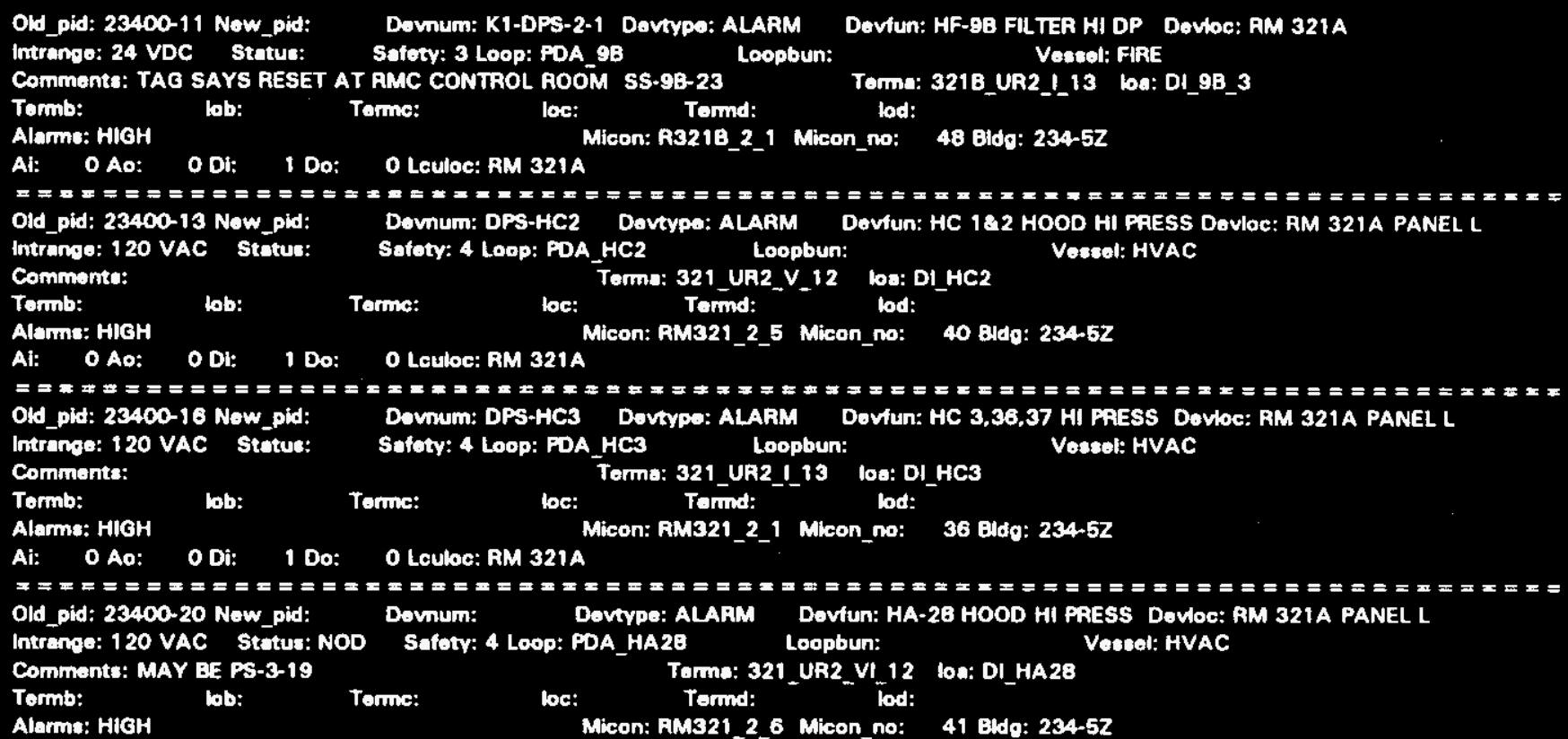

Ai: 0 Aa: 0 Di: 1 Do: 0 Leuloc: RM $321 \mathrm{~A}$

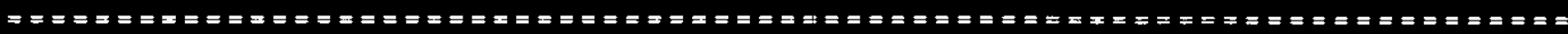
Old_pid: 23400-30 Now_pld: Devnum: K1DPS-1/2-1 Devtypa: ALARM Devfun: RM 309/310 HI DP Devtoc: RM 321A

Intrange: 24 VDC Status: Safoty: 3 Loop: PA_309_10 Loopbun: Vessol: FIAE

Comments: REPLACE BUZZER WITH DI (SEE H-2-97481 SHEET 25) Terma: 321B-UR2-11-27 loa: DI_309_10

Termb: lob: Torme: loc: Micon: R321B 2 2 Micon no: 49 Blda: 234-5Z

Ai: 0 Ao: $O$ Di: 1 Do: 0 Lculoc: RM $321 \mathrm{~A}$

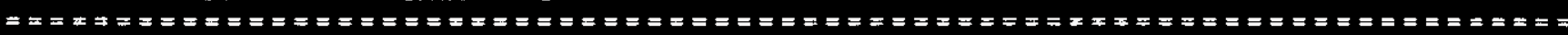
Old pid: 26089-15 Naw_pid: Dovnum: UPS Devtype: ALARM Devfun: ET-8/9 UPS TROUBLE Devoc: RM 321A PANEL N

Intrange: 120 VAC Stotus: Safoty: 3 Loop: XA_UPS Loopbun: Vessel: HVAC

Commente: SEE H-2-96434-5 \& ECN 186232 Torms: 321_UR3 II_11 loa: DI_UPS_t

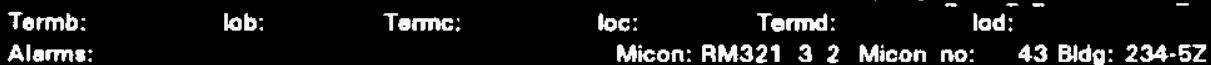

Ai: O Ao: O Ol: 1 Do: 0 Lculoc: RM $321 \mathrm{~A}$

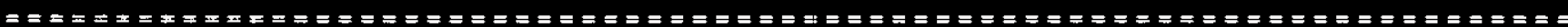
Old_pid: 46894-1 Now_pid: Devnum: DA-IPS-1E Dovtype: ALARM Devfun: HI PRESS SHUTDOWN Devtoc: RM 321A PANEL M Intrange: 120 VAC Status: Sofoty: 3 Loop: PAHH_DAE Loopbun: Vocsel: AIR-E

Comments: SEE H-2-98436-4 (HI PRESSURE FAILURE ON DRAWNG) Terma: 321 UR3 IV_20 Ioa: DI PSHHE

Tormb: lob: Tormc: loc: Micon: RM321 34 Micon no: 45 Bida: 234-52

Ai: O Ao: O Di: 1 Do: O Leuloc: RM $321 \mathrm{~A}$

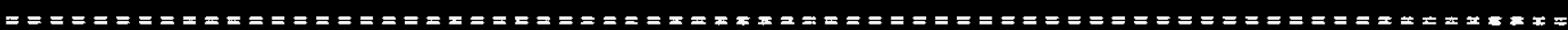
Old pid: 46884-1 Now_pid: Dovnum: DA-IPS-1E Devtype: ALARM Dovfun: HI PAESS WARNING Devbe: RM 321A PANEL M Intrande: 120 VAC Stotus:

Commonts: SEE H-2-96436-4 Sofoty: 3 Loop: PAH DAE Vescol: AIR-E

Tormb: lob: Torme: loc: Tormd: - - lod:

Micon: RM321_3_4 Micon_no: 45 Bldg: 234-5Z

Ai: O Ao: O Di: 1 Do: 0 Lculoc: RM $321 \mathrm{~A}$

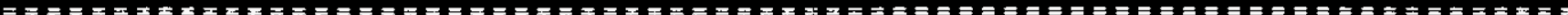
Old_pid: 46884-1 Now_pid: Dovnum: DA-IPS-1S Devtype: ALARM Deviun: HI FRESS SHUTDOWN Devioc: RM 321A PANEL M Intrange: 120 VAC Stotus: Safoty: 3 Loop: PAHH DAS Loopbun: Veceal: AIR-S

Commonts: SEE H-2-96422 (HI FRESSURE SHUTDOWN ŌN DAAWING] Torma: 321 UR3_V_20 loa: DI_PSHHS

Tormb: lob: loc: Tormc: lod:

Alarms: $\quad$ Micon: RM321_35 Micon_no: 46 Bldg: $234-52$

Ai: O Ao: O Di: 1 Do: O Leuloc: RM 321A

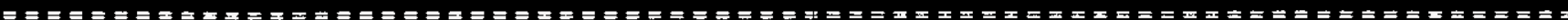

Old_pid: 46884-1 Now_pid: Devnum: DA-1PS-1S Devtype: ALARM Davfun: HI PRESS WARNING Dovloc: RM 321A PANEL M

Intrang: 120 VAC Statu:

Comments: SEE H-2-96422

$\begin{array}{lll}\text { Termb: lob: } \quad \text { Torme: } & \text { Tormd: } & \text { lod: } \\ \text { Alarms: } & & \text { Micon: RM321_3_5 Micon_no: } 46 \text { Bidg: 234-52 }\end{array}$

Safoty: 3 Loop: PAH DAS

Loopbun:

Tema: 321_UR3_V_19 loa: DI_PSHS

Ai: O Ao: O Di: 1 Do: 0 Lculoc: AM 321A

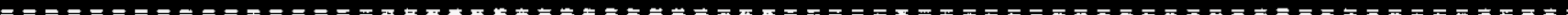

Old_pid: 46884-1 Now_pid:

Intrange: 120 VAC Status:

Dovnum: DA-PS-1/2E Dovtypa: ALARM Dovfun: CLOGGED FILTER ALARM Dovoc: RM 321 A PANEL M Safoty: 3 Loop: PAH DA2E

Loopbun:

Torma: 321_UA3_IV_21 loa: DI_DA3E

eseol: AIR-E

Commente: SEE H-2-96436-4 


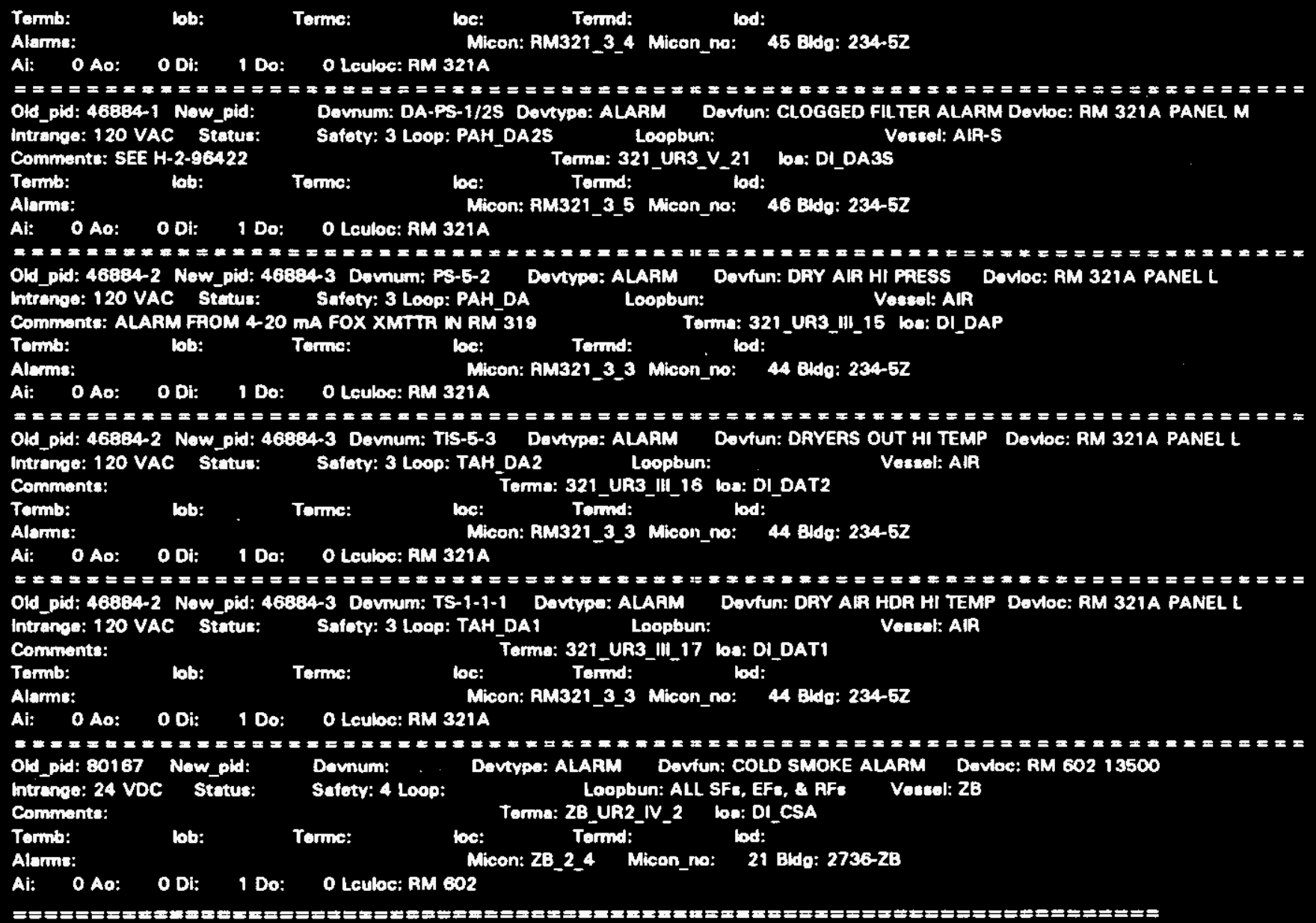

